RAFAEL CARLIN

\title{
A GRAMÁTICA DO CONCEITO FÍSICO DE ENERGIA NO CONTEXTO ESCOLAR DE UMA PERSPECTIVA WITTGENSTEINIANA
}

SÃO PAULO 

RAFAEL CARLIN

\section{A GRAMÁTICA DO CONCEITO FÍSICO DE ENERGIA NO CONTEXTO ESCOLAR DE UMA PERSPECTIVA WITTGENSTEINIANA}

VERSÃO CORRIGIDA DA DISSERTAÇÃO DE MESTRADO APRESENTADA AO PROGRAMA DE PÓS-GRADUAÇÃO INTERUNIDADES EM ENSINO DE CIENNCIAS DA UNIVERSIDADE DE SÃO PAULO PARA A OBTENÇÃO DO TÍTULO DE MESTRE EM ENSINO DE CIÊNCIAS. ÁREA DE CONCENTRAÇÃO: ENSINO DE FÍSICA

UNIVERSIDADE DE SÃO PAULO

PROGRAMA DE PÓS-GRADUAÇÃO INTERUNIDADES EM ENSINO DE CIÊNCIAS

Orientador: Prof. Dra. Cristiane Maria Cornelia Gottschalk

SÃO PAULO

2020 
FICHA CATALOGRÁFICA

Preparada pelo Serviço de Biblioteca e Informação do Instituto de Física da Universidade de São Paulo

Carlin, Rafael

A Gramática do conceito físico de energia no contexto escolar de uma perspectiva wittgensteiniana. São Paulo, 2020.

Dissertação (Mestrado) - Universidade de São Paulo. Faculdade de Educação, Instituto de Física, Instituto de Química e Instituto de Biociências.

Orientador: Profa. Dra. Cristiane Maria Cornelia Gottschalk

Área de Concentração: Ensino de Física

Unitermos: 1. Física - Estudo e ensino; 2. Ensino e aprendizagem; 3. Energia - Estudo e ensino; 4. Ciência. 
A minha mãe, Neuza Ribeiro Soares, que, apesar das dificuldades enfrentadas por pertencer à classe trabalhadora, sempre acreditou na transformação através do estudo. A meu pai, Pedro Luiz Carlin (in memorian), que, apesar de ter sido cético aos frutos do estudo, compreendeu e respeitou a grandeza da aposta de minha mãe em me apoiar incondicionalmente na decisão de estudar. 



\section{Agradecimentos}

Agradeço a minha mãe, Neuza Ribeiro Soares, a meu pai, Pedro Luiz Carlin (in memorian) e a meu irmão, Vitor Carlin, pela paciência e compreensão diante de minha presença esporádica em casa.

A minha companheira, Larissa Ferreira de Aquino, por seu apoio intelectual e prático nos momentos de maior demanda de trabalho e, também, por sua companhia e cuidado em momentos de fragilidade física e psicológica.

A minha orientadora, Cristiane Gottschalk, pela dedicação e paciência em minha formação acadêmica e por seu estilo de orientação que não abandona e nem sufoca.

Aos membros do grupo de estudos FELP (Filosofia, Educação, Linguagem e Pragmática) pelas discussões acadêmicas e pela agradável companhia em momentos de confraternização.

Ao filósofo, Arley Ramos Moreno (in memorian), por sua disponibilidade em discutir filosofia com os membros do FELP e com os alunos da Faculdade de Educação da USP.

Aos professores do Instituto de Física da USP e da Faculdade de Educação. Em especial, ao Dr. Ivã Gurgel, por ter me incentivado a continuar na carreira em momentos de indecisão e a Dra. Cristiane Gottschalk, por ter me ajudado a encontrar um sentido na vida acadêmica.

A meu amigo, Rayner Michel Ribeiro, que me escuta como se eu fosse uma autoridade acadêmica, permitindo-me experimentar o gosto e a responsabilidade desta posição.

Aos professores e alunos do colégio do qual os dados utilizados nesta pesquisa foram coletados e, também, aos professores e alunos dos colégios nos quais trabalhei como professor de física durante o período de realização desta pesquisa que, sem saber, me colocaram diante de questões instigantes relacionadas com o ensino de ciências.

À comunidade do Programa de Pós-graduação Interunidades em Ensino de Ciências. Ao $\mathrm{CNPq}^{1}$, por ter financiado esta pesquisa durante os anos de 2017 e 2018.

$\overline{1 \text { Processo CNPq número 133300/2017-0 }}$ 



\section{Ensinamento}

Minha mãe achava estudo a coisa mais fina do mundo.

Não é

A coisa mais fina do mundo é o sentimento.

Aquele dia de noite, o pai fazendo serão, ela falou comigo:

"Coitado, até essa hora no serviço pesado".

Arrumou pão e café, deixou tacho no fogo com água quente.

Não me falou em amor.

Essa palavra de luxo.

Adélia Prado 



\section{Resumo}

CARLIN, Rafael. A gramática do conceito físico de energia no contexto escolar de uma perspectiva wittgensteiniana. 2020. 170 f. Dissertação (Mestrado) - Instituto de Física, Instituto de Química, Instituto de Biociências, Faculdade de Educação, Universidade de São Paulo, São Paulo, 2020. Versão corrigida.

Os documentos oficiais que regulam o ensino de ciências no ensino médio, assim como a literatura de pesquisa desta área, destacam a relevância do conceito de energia na educação básica. Dentre as expectativas expressas com relação ao ensino do conceito de energia, temos a formação de cidadãos capazes de analisar criticamente questões contemporâneas: como a crise energética e o aquecimento global. Capazes, ainda, de propor novos processos de geração de energia, ao considerar a necessidade de economizar recursos e gerar menos impactos sociais e ambientais. A fim de garantir essas e outras expectativas em relação ao conceito de energia, especialistas em ensino de ciências têm sugerido uma reorientação global no ensino deste conceito. Simultaneamente, os diversos estudos sobre o ensino do conceito de energia e sobre a concepção de energia dos estudantes de diversos níveis da educação básica documentam uma série de dificuldades relacionadas ao ensino e a aprendizagem deste conceito e mostram que, frequentemente, as concepções de energia deles se distanciam daquela sugerida pelos documentos oficias e estudiosos da área. Inspirados na filosofia do segundo Wittgenstein e fundamentados na epistemologia do uso de Arley Ramos Moreno, refletimos sobre o papel da linguagem na formação dos conceitos científicos no contexto escolar, em especial o conceito físico de energia. A partir da observação das aulas de física de uma turma do ensino médio durante um ano letivo, apresentamos algumas evidências da presença de determinados sentidos do conceito de energia que são privilegiados quando comparados com outros sentidos válidos do mesmo conceito. Como é o caso, por exemplo, da definição de energia como capacidade de realizar trabalho. Refletimos sobre as dificuldades que os usos dogmáticos do conceito de energia poderiam representar para a compreensão de alguns de seus aspectos e de determinados problemas do mundo contemporâneo. Concluímos destacando a importância da exemplificação e do uso de experimentos para a formação de um conceito de energia menos dogmático.

Palavras-chave: Conceito. Energia. Ensino. Ciências. Física 



\section{Abstract}

CARLIN, Rafael. The grammar of the physical concept of energy in the school context from a Wittgensteinian perspective. 2020. 170 f. Dissertation (Master) Instituto de Física, Instituto de Química, Instituto de Biociências, Faculdade de Educação, Universidade de São Paulo, São Paulo, 2020. Corrected version.

The official documents that regulate science teaching in high school, as well as the research literature in science teaching, highlight the relevance of the concept of energy in basic education. Among the expectations expressed in relation to the teaching of the concept of energy, we have the training of citizens capable of critically analyzing contemporary issues such as the energy crisis and global warming and capable of proposing new energy generation processes considering the need to save resources and generate less social and environmental impacts. In order to guarantee these and other expectations regarding the concept of energy, specialists in science education have suggested a global reorientation in the teaching of this concept. At the same time, the various studies on the teaching of the concept of energy and on the conception of energy by students at different levels of basic education document a series of difficulties related to the teaching and learning of this concept and show that, frequently, the energy conceptions of students distance themselves from that suggested by official documents and scholars in the field. Inspired by the philosophy of the second Wittgenstein and based on the epistemology of usage of Arley Ramos Moreno, we reflected on the role of language in the formation of scientific concepts in the school context, especially the physical concept of energy. From the observation of the physics classes of a high school class during an academic year, we present some evidence of the presence of certain images of the concept of energy that are privileged when compared with other valid images of the same concept. We reflected on the difficulties that the dogmatics uses of these images could represent for the understanding of certain aspects of the concept of energy and certain problems of the contemporary world. We conclude by

highlighting the importance of the wealth of examples and the use of experiments for the formation of a less dogmatic concept of energy.

Keywords: Concept. Energy. Teaching. Science. Physics. 



\section{Sumário}

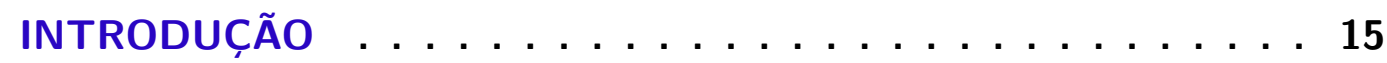

$1.1 \quad 0$ conceito de energia nos documentos curriculares brasileiros . . . 15

1.2 Uma proposta de reorientação do ensino do conceito de energia . . 18

$1.3 \quad$ A terapia filosófica de Wittgenstein . . . . . . . . . . 20

1.4 Algumas características do empreendimento científico . . . . . . 22

1.5 Formulação de nosso problema de pesquisa . . . . . . . . . . 24

2 CONCEPÇÃO WITTGENSTEINIANA DE FILOSOFIA E LINGUA-

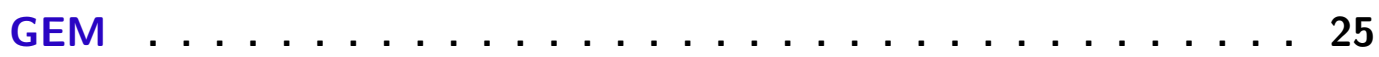

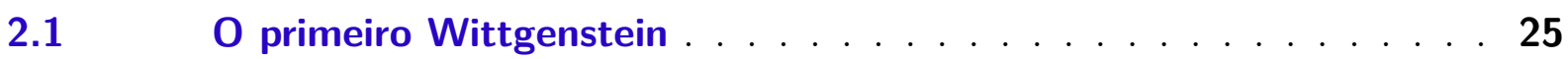

2.2 Concepção de linguagem no segundo Wittgenstein . . . . . . . 30

2.3 Concepção de filosofia no segundo Wittgenstein . . . . . . . . 39

$2.4 \quad \mathrm{O}$ uso dos conceitos e o surgimento das imagens . . . . . . . . . 43

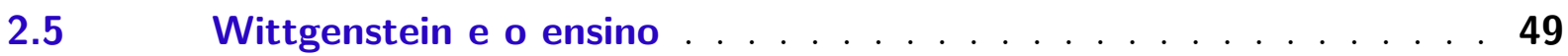

2.6 Síntese do capítulo e consequências para este trabalho . . . . . . . 54

3 REFLEXÕES SOBRE CIÊNCIA, MÉTODO E O CONCEITO DE ENERGIA . . . . . . . . . . . . . . . . 59

$3.1 \quad$ Uma concepção de ciência e método . . . . . . . . . . 59

3.2 Karl Popper e o critério de demarcação da ciência . . . . . . . . 76

3.3 Reflexões sobre a conservação da energia . . . . . . . . . . . 78

3.4 Síntese do capítulo e consequências para este trabalho . . . . . . 882

4 O CONCEITO DE ENERGIA NO CONTEXTO ESCOLAR . . . . 85

$4.1 \quad$ Alguns aspectos do conceito de energia . . . . . . . . . . 85

4.2 Considerações sobre duas coleções de livros didáticos do PNLD 201599

4.3 Observação das aulas de física em uma escola estadual . . . . . . 104

4.3.1 O conceito de energia no material adotado pelo professor . . . . . . . . . 105

4.3.2 Os exercícios propostos pelo professor . . . . . . . . . . . . . . . . . 124

$4.4 \quad$ Intervenção na disciplina de física $\ldots \ldots \ldots \ldots$

4.4.1 Pré-teste e considerações iniciais . . . . . . . . . . . . . . . . 127

4.4.2 Diálogos sobre o significado do conceito de energia e sobre a transformação de energia em uma usina termo-elétrica . . . . . . . . . . . . . . . 130

4.4.3 Pós-teste e aprofundamento de algumas análises . . . . . . . . . . . . 159

5 CONSIDERAÇÕES FINAIS E CONCLUSÃO $\ldots \ldots \ldots \ldots$ 
REFERÊNCIAS $\ldots \ldots \ldots \ldots \ldots \ldots \ldots \ldots \ldots$ 


\section{Introdução}

\subsection{O conceito de energia nos documentos curriculares brasileiros}

Na seção sobre a etapa do ensino médio, a Base Nacional Comum Curricular (BNCC) relaciona a formação de sujeitos críticos, autônomos e responsáveis com as capacidades de realizarem uma leitura do mundo, enfrentar desafios da contemporaneidade e tomar decisões éticas e fundamentadas:

Para formar esses jovens como sujeitos críticos, criativos, autônomos e responsáveis, cabe às escolas de Ensino Médio proporcionar experiências e processos que lhes garantam as aprendizagens necessárias para a leitura da realidade, o enfrentamento dos novos desafios da contemporaneidade (sociais, econômicos e ambientais) e a tomada de decisões éticas e fundamentadas (BRASIL; MEC, 2018, pg. 463).

A BNCC afirma, também, que na etapa do ensino médio deve-se garantir o desenvolvimento das capacidades de abstração, reflexão, interpretação, proposição e ação dos estudantes relacionando estas capacidades à possibilidade da autonomia dos mesmos:

\footnotetext{
a escola que acolhe as juventudes deve garantir o protagonismo dos estudantes em sua aprendizagem e o desenvolvimento de suas capacidades de abstração, reflexão, interpretação, proposição e ação, essenciais à sua autonomia pessoal, profissional, intelectual e política (BRASIL; MEC, 2018, pg. 465).
}

Ainda sobre as finalidades do ensino médio, o documento determina que se proporcione o acesso dos estudantes às bases científicas e tecnológicas que sustentam as cadeias produtivas do mundo contemporâneo de forma que o conhecimento teórico se relacione com a resolução de problemas reais:

a escola que acolhe as juventudes deve viabilizar o acesso dos estudantes às bases científicas e tecnológicas dos processos de produção do mundo contemporâneo, relacionando teoria e prática - ou o conhecimento teórico à resolução de problemas da realidade social, cultural ou natural (BRASIL; MEC, 2018, pg. 466).

Na seção sobre a área de ciências da natureza e suas tecnologias são apresentadas 3 competências específicas a serem desenvolvidas na etapa do ensino médio. A competência específica número 1, prevista pela BNCC no nível do ensino médio, apresenta o conceito de energia como base para a compreensão de fenômenos naturais e processos tecnológicos, bem como a intervenção na realidade conferindo, assim, um papel central para este conceito: 


\begin{abstract}
Analisar fenômenos naturais e processos tecnológicos, com base nas interações e relações entre matéria e energia, para propor ações individuais e coletivas que aperfeiçoem processos produtivos, minimizem impactos socioambientais e melhorem as condições de vida em âmbito local, regional e global (BRASIL; MEC, 2018, pg. 554).
\end{abstract}

Destacaremos duas das sete habilidades relacionadas, na BNCC, com a competência específica número 1. A habilidade de código EM13CNT101 ${ }^{1}$ propõe capacitar os alunos para a análise e representação de processos de transformação e conservação de energia tendo em vista a avaliação de processos sustentáveis:

(EM13CNT101) Analisar e representar, com ou sem o uso de dispositivos e de aplicativos digitais específicos, as transformações e conservações em sistemas que envolvam quantidade de matéria, de energia e de movimento para realizar previsões sobre seus comportamentos em situações cotidianas e em processos produtivos que priorizem o desenvolvimento sustentável, o uso consciente dos recursos naturais e a preservação da vida em todas as suas formas (BRASIL; MEC, 2018, pg. 555).

A segunda habilidade que destacaremos, a habilidade EM13CNT106, também relacionada à competência específica número 1, propõe que os estudantes sejam capazes de avaliar soluções de geração, transporte, distribuição e consumo de energia elétrica levando em consideração, entre outras coisas, os recursos disponíveis e os impactos causados:

(EM13CNT106) Avaliar, com ou sem o uso de dispositivos e aplicativos digitais, tecnologias e possíveis soluções para as demandas que envolvem a geração, o transporte, a distribuição e o consumo de energia elétrica, considerando a disponibilidade de recursos, a eficiência energética, a relação custo/benefício, as características geográficas e ambientais, a produção de resíduos e os impactos socioambientais e culturais (BRASIL; MEC, 2018, pg. 555).

Podemos perceber a relevância do papel atribuído ao conceito de energia pela Base Nacional Comum Curricular. Espera-se que, por meio da aprendizagem de conceitos como o de energia, os estudantes sejam capazes de compreender os fenômenos naturais que os cercam, avaliar tecnologias e processos de produção de energia visando a economia de recursos e a redução de impactos de diversas ordens para que, assim, tenham condições de tomar decisões fundamentadas e interferir na realidade de forma local e global.

Outro documento curricular que apresenta pistas relevantes sobre o papel do conceito de energia no ensino médio são os Parâmetros Curriculares Nacionais. Nos Parâmetros Curriculares Nacionais (PCNs), afirma-se que o abstrato conceito de energia deve ser construído a partir da relação deste conceito com situações reais, evitando, assim,

1 No código da habilidade EM13CNT101 o fragmento EM significa que esta habilidade deve ser desenvolvida no ensino médio, 13 significa que pode ser desenvolvida em qualquer série do ensino médio, $C N T$ faz referência à área de ciências da natureza e suas tecnologias, 1 indica sua relação com a competência específica número 1 e 01 identifica a habilidade. 
definições dogmáticas e tratamentos simplistas do conceito e do princípio de conservação da energia:

Contudo, para que de fato possa haver uma apropriação desses conhecimentos, as leis e princípios gerais precisam ser desenvolvidos passo a passo, a partir dos elementos próximos, práticos e vivenciais. As noções de transformação e conservação de energia, por exemplo, devem ser cuidadosamente tratadas, reconhecendo-se a necessidade de que o "abstrato" conceito de energia seja construído "concretamente", a partir de situações reais, sem que se faça apelo a definições dogmáticas ou a tratamentos impropriamente triviais (BRASIL; MEC, 2000, pg. 24).

Em outro trecho dos PCNs, afirma-se que o conceito de energia e a conservação da energia podem ser ampliados no contexto da termodinâmica na medida em que fenômenos relacionados com o calor e com as transformações entre energia mecânica e térmica são investigados. Além disso, apresenta-se uma reflexão sobre o papel da "degradação da energia" para a compreensão das restrições relacionadas aos processos de transformações de energia e das problemáticas relacionadas à produção e economia de energia:

A Termodinâmica, por sua vez, ao investigar fenômenos que envolvem o calor, trocas de calor e de transformação da energia térmica em mecânica, abre espaço para uma construção ampliada do conceito de energia. Nessa direção, a discussão das máquinas térmicas e dos processos cíclicos, a partir de máquinas e ciclos reais, permite a compreensão da conservação de energia em um âmbito mais abrangente, ao mesmo tempo em que ilustra importante lei restritiva, que limita processos de transformação de energia, estabelecendo sua irreversibilidade. A omissão dessa discussão da degradação da energia, como geralmente acontece, deixa sem sentido a própria compreensão da conservação de energia e dos problemas energéticos e ambientais do mundo contemporâneo (BRASIL; MEC, 2000, pg. 25).

Assim como a BNCC, os PCNs também afirmam a necessidade de relacionar o conhecimento teórico com os problemas enfrentados pela sociedade contemporânea, tendo em vista a capacitação dos estudantes para a análise crítica de informações e a intervenção na realidade social, ambiental, econômica na qual está inserido:

Ao mesmo tempo, devem ser promovidas as competências necessárias para a avaliação da veracidade de informações ou para a emissão de opiniões e juízos de valor em relação a situações sociais nas quais os aspectos físicos sejam relevantes. Como exemplos, podemos lembrar a necessidade de se avaliar as relações de risco/benefício de uma dada técnica de diagnóstico médico, as implicações de um acidente envolvendo radiações ionizantes, as opções para o uso de diferentes formas de energia, as escolhas de procedimentos que envolvam menor impacto ambiental sobre o efeito estufa ou a camada de ozônio, assim como a discussão sobre a participação de físicos na fabricação de bombas atômicas (BRASIL; MEC, 2000, pg. 28). 
Como vimos, ambos os documentos atribuem um papel de destaque ao conceito de energia e ao princípio de conservação da energia na formação dos estudantes do ensino médio. Atribui-se ao aprendizado do conceito de energia, e suas relações com os demais conceitos e princípios de conservação, a possibilidade de compreensão de fenômenos naturais complexos e o enfrentamento de problemáticas contemporâneas por meio da análise crítica e do posicionamento fundamentado.

Diante deste cenário, emergem diversas questões relacionadas ao conceito de energia e seu ensino efetivo. Por exemplo, parecem relevantes as questões: o destaque atribuído ao conceito de energia é também verificado nos currículos efetivos do ensino médio? e o conceito de energia tem sido ensinado de forma que os objetivos almejados possam ser alcançados?. Interessa-nos, em especial, uma abordagem filosófica destas questões.

\subsection{Uma proposta de reorientação do ensino do conceito de energia}

A importância do conceito de energia para a compreensão de fenômenos da física, química, biologia e tecnologia é praticamente um consenso entre os professores (DOMéNECH et al., 2007). Questões relacionadas à energia apresentam implicações pessoais, sociais e ambientais que, uma vez compreendidas, possibilitam que os estudantes tomem decisões informadas para problemas emergentes no mundo contemporâneo, como é o caso da crise energética (DOMéNECH et al., 2007).

Doménech et al. (2007) defendem que o conhecimento científico, especificamente o conceito de energia, deve ser reconstruído pelos estudantes de forma que percebam que o conhecimento científico é uma tentativa de resolução de determinados problemas, através de procedimentos e critérios específicos de cada área. Para que essa reconstrução do conhecimento seja possível, o autor apresenta 3 aspectos que deveriam ser garantidos na atividade de ensino, são eles:

1. O conhecimento científico não deveria ser diretamente apresentado em sua forma final como algo a ser aceito.

2. Os estudantes deveriam ter oportunidades de utilizar estratégias de elaboração e critérios de validação do conhecimento, que são características do conhecimento científico.

3. Os estudantes deveriam compreender, particularmente, que a integração entre a mecânica e a termodinâmica foi uma profunda revolução científica que permitiu o estabelecimento do princípio de conservação da energia.

Doménech et al. (2007) destacam ainda alguns aspectos do conceito de energia que, juntos, constituem uma visão global deste conceito considerada mais adequada pelos 
autores, são alguns deles:

1. A definição do conceito de energia como a capacidade de um corpo realizar trabalho é suficiente apenas no contexto da mecânica: Durante o processo de aprendizado, os estudantes deveriam ter acesso ao contexto histórico em que os conhecimentos científicos foram apresentados como soluções eficazes para determinados problemas.

2. Os conceitos de trabalho e calor não são tipos de energia mas, antes, processos distintos de transferência de energia: enquanto o trabalho representa um processo de transferência de energia pela aplicação de uma força à um corpo, provocando seu deslocamento, o calor representa a somatória dos efeitos dos choques entre as partículas de diferentes partes de um sistema ou de sistemas diferentes.

3. Não faz sentido falar em energia de corpos isolados mas, antes, em energia como uma característica de um sistema cujos corpos constituintes interagem entre si: Nosso costume de falar sobre a energia cinética de um corpo à determinada velocidade ou sobre a energia potencial gravitacional de um corpo à certa altura da superfície da Terra assume, tacitamente, a possibilidade de interação entre corpos que se movem e a força gravitacional que age entre o planeta Terra e o corpo em questão.

4. Não faz sentido falar em energia em termos absolutos. A energia, por exemplo cinética ou potencial gravitacional, de um sistema de corpos é relativa. Algum valor de energia é convencionado para que outros valores de energia possam ser calculados em relação a este: Para a análise dos fenômenos físicos e, consequentemente, para a compreensão das transformações dos sistemas importam apenas as variações de energia estabelecidas a partir da adoção de um referencial arbitrário.

5. A relação entre os fenômenos da termodinâmica e da mecânica é fundamental para a compreensão do princípio de conservação da energia e, portanto, este princípio não pode ser derivado diretamente das leis da dinâmica newtoniana: Historicamente, o princípio de conservação da energia surgiu a partir da organização de diversos processos de conversão entre fenômenos físicos de naturezas diversas (mecânica, termodinâmica, elétrica, química...) e em íntima relação com os estudos sobre máquinas à vapor.

6. A energia se conserva mas, ao mesmo tempo, se degrada: Isso significa que as transformações de energia em um sistema ocorrem de forma que a distribuição de energia entre suas partes se torne cada vez mais homogênea inviabilizando, assim, a ocorrência de determinados processos no futuro.

7. A conservação da energia está associada às possibilidades de mudanças que um sistema pode sofrer mas não é a causa dessas mudanças: As transformações dos sistemas ocorrem para satisfazer a lei da entropia ou a "degradação da energia". 
8. A energia é uma quantidade, calculada segundo regras específicas de cada contexto, que se conserva em sistemas fechados: A concepção de energia como entidade material que pode ser armazenada ou que se encontra em determinada localidade contradiz esta compreensão.

A consolidação desta proposta de reorientação do ensino de energia, sugerida por Doménech et al. (2007), depende da superação de alguns obstáculos encontrados em diversos âmbitos do ensino de ciências como, por exemplo, na formação de professores de ciências, na formulação de diretrizes educacionais e curriculares, bem como na elaboração e distribuição de livros didáticos e na cultura de ensino de ciências já estabelecida no cotidiano escolar.

No escopo deste trabalho, nos concentramos em alguns obstáculos de natureza conceitual que se colocam contra a consolidação das propostas de ensino de ciências apresentas pelos documentos curriculares e contra a reorientação do ensino do conceito de energia proposta por Doménech et al. (2007).

A hipótese que assumimos para a elaboração do projeto de pesquisa cujo resultado aqui apresentamos, foi a de que podem haver determinadas compreensões dominantes do conceito de energia que, por um lado, podem inviabilizar a capacidade dos estudantes de compreender e analisar fenômenos naturais complexos e tomarem decisões fundamentadas no que diz respeito à questões problemáticas do mundo contemporâneo e, por outro, exerçam influências limitadoras na atividade de ensino dos professores de ciências do ensino básico e, mesmo, dos professores de cursos de formação para professores de ciências.

Para refletir sobre esta questão, recorremos à terapia filosófica, método aplicado na segunda fase do filósofo Ludwig Wittgenstein e presente, principalmente, na obra Investigações filosóficas.

\subsection{A terapia filosófica de Wittgenstein}

A terapia filosófica é um método de elucidação e dissolução de problemas filosóficos gerados pela aplicação dogmática de certas imagens de conceitos. Originalmente, o método foi desenvolvido e utilizado pelo filósofo Ludwig Wittgenstein com a finalidade de escapar das confusões oriundas da imagem referencial da linguagem, presente nas reflexões de Agostinho sobre o aprendizado da linguagem e também na primeira fase do pensamento do próprio Wittgenstein em sua obra, Tractatus Logico-Philosophicus. Esta imagem pode ser sintetizada na afirmação de que o significado da palavra é o objeto que ela substitui ou ao qual faz referência.

A partir da leitura de escritos de Wittgenstein e seus comentadores, podemos afirmar que, na segunda fase de seu pensamento, o filósofo apresenta um outro modo de 
ver o funcionamento da linguagem, em que o significado das palavras está intimamente relacionado com a maneira através da qual nos comportamos, isto é, com nossos hábitos diante do mundo e nossas ações que se relacionam com as palavras. Desta forma, o significado das palavras é estabelecido no interior de uma comunidade que compartilha os mesmos pressupostos linguísticos, assentados em uma forma de vida (MORENO, 1995).

Os membros destas comunidades incorporam tais pressupostos linguísticos, inicialmente, através de dinâmicas preparatórias para o uso da linguagem nas quais as regras de associação entre palavras, objetos e ações são apresentadas pelos membros mais velhos da comunidade e aceitas pelo membros mais jovens e, posteriormente, através do próprio uso das palavras nos mais diversos contextos em que seu uso foi, ou não, previsto. Estas regras de aplicação das palavras, pressupostos linguísticos compartilhados que fundamentam a comunicação, fazem parte do que o filósofo denominará de gramática das palavras e de expressões linguísticas em suas investigações filosóficas (MORENO, 1995).

Na constituição da gramática das palavras surgem os conceitos, ou seja, palavras tornam-se conceitos na medida em que seu escopo de aplicação é suficientemente definido. Os conceitos, no entanto, não necessitam ser exatamente definidos para que tenham eficácia mas, apenas, suficientemente definidos de forma que sejam possíveis novos usos do conceito que não haviam sido previstos anteriormente. No entanto, na medida em que os conceitos são aplicados com finalidades específicas pode-se optar por uma definição mais exata do conceito (MORENO, 1995).

Na medida em que esta definição, legítima em determinado contexto, passa por um processo de naturalização, isto é, esquece-se que é fruto de uma convenção realizada em determinado momento e contexto, surgem os usos dogmáticos dos conceitos. O dogmatismo é fruto do reconhecimento de apenas uma das diversas possibilidades de aplicação de uma palavra, da determinação inequívoca do significado de um termo que não reconhece os demais usos como legítimos e apresenta-se como necessário e essencial (MORENO, 1995).

Nas Investigações filosóficas, Wittgenstein critica a concepção referencial presente em Agostinho, fonte de diversas confusões de natureza conceitual. Seu método, a terapia filosófica, consiste em explorar as diversas funções da linguagem em contraposição ao seu uso referencial, único reconhecido por Agostinho. Na medida em que explora essas diversas funções, o filósofo pretende mostrar a gramática mais abrangente do conceito de linguagem, permitindo assim que o leitor relativize a força da necessidade da concepção referencial escapando, assim, das confusões filosóficas oriundas da aplicação desta concepção às mais diversas questões (WITTGENSTEIN, 2000).

Neste sentido, recorreremos à terapia filosófica de Wittgenstein para tratar do uso dogmático do conceito de energia no contexto escolar. Dado que, de um ponto de vista wittgensteiniano, o sentido do conceito é o seu uso e que o contexto de aplicação do conceito físico de energia seja a tradição científica, entendemos que uma apresentação 
abrangente de algumas características desta tradição, a ciência, seja necessária para a melhor compreensão deste trabalho.

\subsection{Algumas características do empreendimento científico}

Uma vez que os documentos curriculares mencionam a importância de ensinar o conceito de energia e sua conservação de forma contextualizada e que a concepção de linguagem do segundo Wittgenstein relaciona, fortemente, o significado das palavras com seus usos e as formas de vida nas quais estes usos possuem sentido, consideramos apropriado refletir brevemente acerca de algumas características de uma das maiores tradições da humanidade, o empreendimento científico. Além disso, apresentamos algumas considerações a respeito do estabelecimento do princípio de conservação da energia em relação com o contexto científico e tecnológico da época de sua enunciação, explorados por Thomas Kuhn.

A reflexões sobre ciência e método apresentadas neste trabalho estão fundamentadas nas obras de José Mário Pires Azanha, Thoman Kuhn, Paul Feyerabend e Karl Popper. Inicialmente, Azanha (2011) apresenta algumas características de uma visão de ciência e método, bastante conhecida e difundida, denominada received view:

\footnotetext{
Essa concepção [...] era amplamente comprometida com o neopositivismo, mas também caudatária de outras correntes de pensamento na comunidade científica desde o final do século passado. Além dessas condicionantes mais próximas, a received view foi o desaguadouro histórico das profundas alterações ocorridas no quadro do pensamento científico e filosófico do século XVII e de sua evolução nos séculos posteriores. Nessas condições, essa visão de ciência é, no final das contas, filha legítima tanto do baconismo como do cartesianismo (AZANHA, 2011, pg. 168).
}

Uma característica especial desta visão de ciência e método, e importante para as reflexões seguintes, é a concepção de que a ciência é um tipo de conhecimento produzido a partir da aplicação de um método especial. Segundo Azanha (2011):

\footnotetext{
... Bacon e Descartes foram homens que, a partir de diferentes "ideais explicativos" defenderam a ideia de que a ciência é um tipo de conhecimento cuja obtenção é fruto de aplicação de um método especial. Na verdade, eles foram ainda mais longe porque acreditaram que a racionalidade se esgotava na ciência, e esta, na adequada utilização de um método (AZANHA, 2011, pg. 168).
}

Em seguida, Azanha apresenta algumas críticas direcionadas por Thomas Kuhn e Paul Feyerabend contra esta concepção de ciência. Na verdade, as críticas direcionadas por Kuhn e Feyerabend apenas representam um movimento crítico muito maior protagonizado por diversos cientistas e filósofos. As críticas de Kuhn e Feyerabend, nos permitem, entre 
outras coisas, reconhecer o papel de aspectos convencionais na constituição da cultura científica de uma determinada comunidade relativizando, assim, a concepção de que a ciência seja produzida pela aplicação de um método especial e fundamentada em uma única racionalidade.

Em especial, os filósofos da ciência refletem sobre a interdependência entre teorias científicas e a observação de fatos da natureza, sobre a relação entre os conceitos científicos e os procedimentos canônicos de experimentação e, também, sobre o papel da formação de novos cientistas na viabilização das revoluções científicas. Estas reflexões nos parecem pertinentes para este trabalho pelo fato de destacarem o papel da linguagem e da educação no empreendimento científico.

Evitando dar margens para o relativismo ao questionar a concepção de ciência atrelada à aplicação de um método especial, Azanha (2011) adota a sugestão de Karl Popper de estabelecer um critério mínimo de demarcação entre as atividades científicas e não-científicas, a saber, a produção de teorias cujas proposições resultantes fossem passíveis de verificação, ou seja, teorias passíveis de falsificação a partir da verificação de suas proposições.

Dessa forma, abandonamos a crença de que seja possível descrever um único método especial correspondente à ciência, passando a aceitar diferentes métodos de investigação científica sem, contudo, assumir a necessidade de aceitar qualquer atividade como científica.

Além dessas reflexões sobre ciência e método, apresentamos algumas considerações sobre o estabelecimento do princípio de conservação da energia em seu contexto histórico original. Kuhn (1989) defende que o princípio de conservação da energia foi viabilizado por uma combinação de fatores, a saber, a descoberta e sistematização de diversos processos capazes de relacionar fenômenos de naturezas diversas entre si, o interesse da comunidade de pesquisadores nas máquinas térmicas e a importação do conceito de trabalho, utilizado nas engenharias de máquinas térmicas, para o estudo dos processos de conversão nas diversas áreas da física.

Essas considerações sobre a conservação da energia nos permitem compreender a relevância das diferentes práticas científicas para o estabelecimento do conceito de energia e do princípio de conservação da energia, assim como a multiplicidade dos aspectos da gramática do conceito de energia quando consideramos seus empregos em cada um dos diferentes âmbitos da ciência.

Podemos afirmar, a partir destas considerações, que o conceito de energia possui um aspecto local e outro geral. Seu aspecto local diz respeito aos diferentes usos feitos do conceito nos diversos ramos da ciência enquanto que seu aspecto geral diz respeito à síntese proporcionada pelo princípio de conservação da energia que apresenta a energia como uma quantidade numérica que, calculada de maneiras diversas em diferentes contextos, 
mantém-se constante no decorrer dos processos de transformação conhecidos. Acreditamos que enfatizar esta distinção pode contribuir para o esclarecimento de confusões na aplicação deste conceito no contexto escolar, como explicitaremos mais ao longo do trabalho.

\subsection{Formulação de nosso problema de pesquisa}

Inspirados na terapia filosófica de Ludwig Wittgenstein, apontamos as concepções de energia mais influentes no ensino de ciências e destacamos suas limitações frente às expectativas apresentadas pelos documentos curriculares com relação ao ensino de ciências e os obstáculos que constituem para a reorientação do ensino do conceito de energia proposta por Doménech et al. (2007). Além disso, exploramos o papel da etapa preparatória, para o uso do conceito de energia, evitando-se, assim, o ensino dogmático deste conceito.

As questões a seguir nortearam as observações e análises apresentadas ao longo desta dissertação:

1. Existem usos dogmáticos do conceito de energia no contexto escolar?

2. De que forma esse dogmatismo pode constituir um obstáculo à reorientação global do ensino deste conceito?

3. Qual o papel da linguagem no ensino do conceito de energia?

4. Quais os efeitos dos usos dogmáticos do conceito de energia no ensino de ciências?

5. Como evitar o surgimento de concepções dogmáticas ${ }^{2}$ do conceito escolar de energia?

Nossa análise incidirá inicialmente sobre a apresentação do conceito de energia em duas coleções de livros didáticos de física aprovadas pelo PNLD 2015, o material didático adotado pelo professor de física de uma turma do ensino médio observado por nós ao longo de um ano letivo e as atividades formativas e avaliativas propostas pelo mesmo professor durante o primeiro semestre do ano letivo. Em seguida, nossa análise incidirá sobre os diálogos travados durante a aplicação de uma Sequência Didática elaborada e aplicada em conjunto com o professor da disciplina e, por fim, analisaremos os resultados do pré-teste e do pós-teste aplicados ao início e ao final da Sequência Didática.

2 Utilizamos "concepção dogmática" para nos referir à concepção de energia presente nos documentos, livros didáticos e práticas escolares mais diretamente ligados ao ensino de ciências. Acreditamos que, apesar de guardar algumas semelhanças com as concepções de energia das próprias ciências, as concepções de energia do contexto escolar devem apresentar, também, suas especificidades, visto que seus sentidos são constituídos no interior de uma prática com seus próprios jogos de linguagem. 


\title{
2 Concepção wittgensteiniana de filosofia e linguagem
}

Nosso problema de pesquisa será melhor compreendido se apreciado a partir de uma certa concepção de filosofia e linguagem. Uma concepção presente nas obras da segunda fase do filósofo Ludwig Wittgenstein e que, por isso, chamamos wittgensteiniana. Optamos por apresentar a segunda fase do filósofo em contraste com sua primeira fase de forma que as mudanças em suas concepções de linguagem e filosofia fiquem mais evidentes.

\subsection{O primeiro Wittgenstein}

Ludwig Josef Johann Wittgenstein nasceu em Viena no ano de 1889, estudou engenharia aeronáutica na Universidade de Manchester e lógica no Trinity College. Enquanto cursava engenharia, Wittgenstein chegou a projetar um motor a jato e um propulsor. No entanto, seus interesses foram orientando-se, pouco a pouco, para a matemática pura e, em seguida, para os fundamentos da matemática. Influenciado pelos Princípios da Matemática, de Bertrand Russell, abandonou a engenharia e matriculou-se, em 1912, no Trinity College, onde se dedicou à lógica sob orientação do próprio Russell (WITTGENSTEIN, 2000).

Além de ter sido influenciado pelos Princípios da Matemática de Russell, Wittgenstein foi influenciado pelos Princípios da Mecânica de Heinrich Hertz e pelas Conferências Sobre a Teoria do Gás de Ludwig Boltzmann. Inclusive, Wittgenstein planejou estudar sob a orientação de Boltzmann. No entanto, nas vésperas da concretização deste plano, Ludwig Boltzmann cometeu suicídio devido suas disputas com Ernest Mach, Wilhelm Otswald e seus seguidores. Segundo Janik e Toulmin (1991):

\begin{abstract}
Boltzmann, que se identificava como continuador das obras de Hertz, foi incapaz de superar as duras críticas de Mach, Otswald e seus seguidores; essa hostilidade foi, na verdade, um fator importante no desequilíbrio mental de seus últimos anos, o que o levou finalmente ao suicídio - no momento exato em que o jovem Wittgenstein se preparava para estudar sob sua orientação (JANIK; TOULMIN, 1991, pg. 162).
\end{abstract}

Enquanto Mach defendia uma concepção de conhecimento na qual o homem apresentava um papel passivo em sua elaboração e nossos esquemas conceituais eram soluções econômicas para enfrentarmos problemas práticos, Hertz defendia uma concepção de conhecimento na qual nossos esquemas conceituais eram conscientemente construídos pelo homem para o conhecimento (JANIK; TOULMIN, 1991). Segundo Hertz: 


\begin{abstract}
São possíveis vários modelos [Bilder] dos mesmos objetos, e esses modelos podem diferir em vários aspectos. Devemos assinalar imediatamente como inadmissíveis todos os modelos que implicitamente contradizem as leis do nosso pensamento. Por conseguinte, postulamos que, em primeiro lugar, todos os nossos modelos serão logicamente permissíveis - ou, sucintamente, que eles serão permissíveis. Distinguiremos como incorretos quaisquer modelos permissíveis se as suas relações essenciais contradizem as relações com as coisas externas, isto é, se não satisfazem o nosso primeiro e fundamental requisito(HERTZ, 1956 apud JANIK; TOULMIN, 1991, pg. 156).
\end{abstract}

É interessante notar, na formulação de Hertz, o papel atribuído à lógica na elaboração de modelos que, posteriormente, serão utilizados para a descrição dos fenômenos da mecânica. Hertz reconhece a possibilidade de vários modelos dos mesmos objetos e utiliza um critério externo, as leis do nosso pensamento, para a exclusão de parte desses modelos para, em seguida, avaliar se os demais modelos apresentam alguma correspondência com as coisas externas. Esta característica também é observada na teoria de Boltzmann. Segundo Janik e Toulmin (1991):

Boltzmann considerou que a descrição hertziana de mecânica definia um
sistema de "possíveis sequências de eventos observados", e fez dela o ponto
de partida para um método geral de análise teórica na própria física. Para
isso, tratou cada propriedade independente de um sistema físico como
definidora de uma coordenada separada num sistema multidimensional
de coordenadas geométricas. Todas as localizações possíveis de cada
corpo separado no sistema físico, por exemplo, estavam ordenadas ao
longo de três "eixos espaciais de referência"; todos os valores, digamos,
de temperatura ao longo de um outro eixo; todos os valores da pressão
ao longo de um quinto; e assim por diante. A totalidade de "pontos"
teóricos no resultante sistema multidimensional de coordenadas fornecia
uma representação do "conjunto de estados possíveis" do sistema físico
em questão; e qualquer estado podia ser definido especificando-se o ponto
nesse "espaço multidimensional" cujas coordenadas correspondiam aos
valores reais de todas as variáveis (JANIK; TOULMIN, 1991, pg. 160).

Notamos, novamente, um método no qual o levantamento do conjunto de estados possíveis, segundo uma lógica, é o primeiro passo na tentativa de descrever os fenômenos externos. A etapa seguinte do método de Boltzmann, considerado o pai da mecânica estatística, consiste em confrontar tais estados com os fenômenos empíricos, mas segundo uma nova concepção, na qual a estatística possui papel central. Segundo Janik e Toulmin (1991):

O problema geral para a mecânica estatística era, pois, descobrir as relações matemáticas que regem as frequências com que - com base em várias suposições e condições - os estados reais de um sistema físico seriam distribuídos entre os seus estados possíveis, e, assim, calcular as relativas probabilidades de encontrar o sistema num estado físico global e não em outros (JANIK; TOULMIN, 1991, pg. 161). 
Wittgenstein, por sua vez, utiliza a noção de um "espaço de possibilidades lógicas" na fundamentação da linguagem proposta no Tractatus Logico-Philosophicus. Segundo Wittgenstein (2010b):

Os fatos no espaço lógico são o mundo; o mundo dividi-se em fatos; cada item pode ser o caso ou não ser o caso, enquanto tudo o mais permanece o mesmo... Construímos para nós mesmos representações (Bilder) de fatos.

Uma Bild retrata a realidade representando uma possibilidade de existência e não-existência de estados de coisas. Uma Bild representa uma situação possível no espaço lógico.

Uma proposição determina um lugar no espaço lógico... Em geometria e em lógica, um lugar é uma possibilidade: alguma coisa pode existir nele. (WITTGENSTEIN, 2010b apud JANIK; TOULMIN, 1991, pg. 161)

Essa formulação de Wittgenstein está fortemente fundamentada no simbolismo lógico desenvolvido por Russell e Frege, especialmente no "cálculo proposicional" de Russell. Wittgenstein encontra no "cálculo proposicional" de Russell a "lógica da linguagem" de que precisava para demonstrar os limites da linguagem através de uma crítica interna. Assim, a natureza e limites da linguagem poderiam ser evidenciados no lugar de ser explicitamente enunciados (JANIK; TOULMIN, 1991).

É interessante notar que, assim como Hertz e Boltzmann fizeram na física, Wittgenstein procura descrever a linguagem a partir de dentro com a finalidade de evidenciar, ou mostrar, sua natureza e possibilidades fundamentando-a numa lógica. Também como Hertz e Boltzmann, Wittgenstein se preocupa com as condições necessárias para que tal linguagem possa ser utilizada com a finalidade de descrever o mundo, ou seja, que suas proposições correspondam a fatos externos a ela. Sua conclusão é que linguagem e mundo precisam compartilhar uma forma lógica, isto é, que as relações entre os nomes constituintes de uma proposição da linguagem apresentem um "isomorfismo" com as relações entre os objetos constituintes do mundo. Tendo essa condição satisfeita se poderia, então, avaliar quais proposições correspondem ou não correspondem a fatos externos. Segundo Janik e Toulmin (1991):

\footnotetext{
Assim, duas coisas são essenciais à teoria da linguagem de Wittgenstein: uma teoria de correspondência da verdade e o pressuposto que existe um suficiente "isomorfismo" (Verbindung) entre linguagem e realidade para permitir - e validar - todo o nosso uso descritivo da linguagem. A estrutura lógica da linguagem possibilita-nos apurar a priori se certas configurações de objetos são, ou não são, "possíveis" (JANIK; TOULMIN, 1991, pg. 214).
}

A compreensão do espírito em que o Tractatus Logico-Philosophicus foi escrito exige o conhecimento das motivações de Wittgenstein. Inspirado no mapeamento exaustivo, de dentro para fora, que Hertz e Boltzmann haviam realizado na física, Wittgenstein tinha 
a intenção de fazer o mesmo para a linguagem-em-geral, ou seja, mapear os limites da linguagem a partir da exposição de sua estrutura interna. No entanto, pautar-se em apenas essa motivação pode nos conduzir à interpretações equivocadas, como as que fizeram os membros do Círculo de Viena, do Tractatus.

Wittgenstein também tinha em conta mostrar que questões como as da ética, da estética e do místico situavam-se fora dos limites de significação da linguagem. No entanto, considerou que estas considerações seriam subprodutos de sua análise acerca dos limites da linguagem e, por isso, não se deteve na análise destas temáticas, mesmo porque isso seria um contrassenso. Segundo Toulmin (1969):

\begin{abstract}
Existe algum método para fazer pela linguagem-em-geral o que Hertz e Boltzmann já fizeram pela linguagem da física teórica? Ou seja, existe algum modo de mapear exaustivamente a extensão e os limites do "dizível" de dentro para fora, de forma que se possa ver como a linguagem descritiva em geral é usada para oferecer uma bildliche Darstellung na acepção hertziana de uma representação na forma de um modelo matemático de todas as matérias de fato, e também como o caráter "transcendente" de todas as questões éticas - o que as torna somente passíveis de "comunicação indireta" - se mostra, ao mesmo tempo, como subproduto da análise? (TOULMIN, 1969 apud JANIK; TOULMIN, 1991, pg. 187)
\end{abstract}

O Tractatus Logico-Philosophicus atraiu a atenção de um grupo de filósofos liderados por Moritz Schlick - grupo que acabou se transformando no Círculo de Viena de positivistas lógicos - após a apresentação de um seminário sobre o livro pelo matemático Hans Hahn em 1922 (MONK, 1995). Em uma carta para Wittgenstein Schlick reconhece o valor de sua obra:

\footnotetext{
Nos semestres de inverno, mantenho encontros regulares com colegas e alunos de talento interessados nos fundamentos da lógica e da matemática, e o seu nome tem sido mencionado com frequência neste grupo [...]. De modo que há diversas pessoas aqui - eu mesmo sou uma delas - que estão convencidas da importância e validade de seu pensamento, e que têm um forte desejo de contribuir para sua divulgação (MONK, 1995, pg. 224).
}

Apesar de encontrar em Schlick um companheiro de discussão refinado e compreensivo, Wittgenstein não concordou em participar dos encontros do Círculo de Viena porque, segundo ele, só conseguia discutir com alguém a quem pudesse "dar as mãos" (MONK, 1995). Apesar disso, Wittgenstein manteve encontros regulares com um grupo que incluía Schlick e alguns seletos membros do Círculo de Viena como, por exemplo, Friedrich Waismann, Rudolf Carnap e Herbert Feigl. As impressões de Carnap acerca desses encontros fornecem uma pista de como os membros do Circulo de Viena haviam interpretado o Tractatus de forma equivocada:

Quando lemos pela primeira vez o livro de Wittgenstein no Círculo, eu havia erroneamente acreditado que sua atitude em relação à metafísica 
era semelhante à nossa. Eu não prestara atenção suficiente às asserções sobre o místico presentes no livro, uma vez que seus sentimentos e ideias nessa área divergiam por demais dos meus. Somente o contato pessoal permitiu que eu compreendesse mais claramente sua posição neste ponto (MONK, 1995, pg. 226).

Fica evidente que a posição antimetafísica adotada pelos positivistas lógicos e fundamentada em uma leitura equivocada do Tractatus não era compartilhada por Wittgenstein que, em um esforço por desfazer o mal entendido de que sua obra havia sido escrita em um espírito positivista e antimetafísico, apresentou um trabalho a uma sociedade voltada à ciência denominada "Hereges", do qual apresentamos um trecho:

Minha inclinação, e creio que a de todos os homens que tentaram escrever ou falar sobre ética ou religião, era lançar-me contra os limites da linguagem. Esse lançar-se contra as grades de nossa jaula é algo perfeita e absolutamente sem esperança. A ética, na medida em que brota do desejo de dizer algo sobre o sentido da vida, o bem absoluto, o valor absoluto, não pode ser ciência. O que ela afirma nada acrescenta ao nosso conhecimento. Mas é um documento de uma tendência na mente humana pela qual eu pessoalmente não posso senão ter o mais profundo respeito e que jamais em minha vida poderia ridicularizar (MONK, 1995, pg. 254).

A partir destas considerações podemos melhor compreender o significado das tão famosas afirmações de Wittgenstein acerca dos limites da linguagem, a saber, "sobre aquilo que não se pode falar deve-se calar." (WITTGENSTEIN, 2010b) e que "o que não dissera no Tractatus era mais importante do que o que dissera" (MONK, 1995). Longe de se identificar com a postura antimetafísica dos positivistas lógicos do Círculo de Viena, Wittgenstein estava preocupado em delimitar o rol de temas sobre os quais a linguagem poderia ser aplicada com função descritiva, ou seja, sobre os quais se podia fazer ciência. Em uma carta enviada à Ficker, na tentativa de que este publicasse sua obra, Wittgenstein afirma:

Eu pretendia esclarecer que a obra consiste em duas partes: a que está aqui e tudo aquilo que eu não escrevi. E a parte importante é precisamente a segunda. Pois a ética é delimitada internamente, por assim dizer, em meu livro; e estou convencido de que, estritamente falando, ela só pode ser delimitada dessa maneira. Em resumo, penso que: tudo aquilo sobre o que muitos hoje estão discorrendo a esmo eu defini em meu livro simplesmente calando-me a respeito (JANIK; TOULMIN, 1991, pg. 170).

Em resumo, a concepção de linguagem do primeiro Wittgenstein se reduz ao que hoje compreendemos como o uso descritivo da linguagem, ou seja, aquilo que, por meio da linguagem, podemos falar sobre o mundo. Desta forma, para o filósofo do Tractatus, tanto as proposições da linguagem como as proposições da ciência devem representar fatos possíveis do mundo para que tenham sentido. No entanto, isso não significa que Wittgenstein reconhecesse como importante apenas o que a ciência fosse capaz de dizer 
mas, antes disso, que estava preocupado com a extrapolação do discurso e do método científico para outros campos que lhes eram muito caros.

Sua constatação de que se deveria calar sobre o que se encontra fora dos limites da linguagem era uma tentativa de persuadir os filósofos a não tentarem descrever - no sentido de fazer ciência de - temas como a ética, a estética e o sentido da vida.

\subsection{Concepção de linguagem no segundo Wittgenstein}

Em sua segunda fase, Wittgenstein critica a concepção de linguagem do Tractatus. No Tractatus, a relação entre linguagem e mundo era imediata e garantida por uma forma lógica compartilhada e, além disso, o ponto de contato entre linguagem e mundo se daria através da equivalência entre nomes, na linguagem, e objetos, no mundo. Ambos, nomes e objetos, deveriam apresentar a característica de serem logicamente simples, ou seja, de não serem passíveis de análise, de serem unidades da linguagem e do mundo respectivamente.

Logo no primeiro parágrafo das Investigações Filosóficas, o filósofo apresenta e critica à concepção referencial da linguagem representada num trecho de Agostinho. Para Agostinho, cada palavra denomina um objeto do mundo e as frases são ligações entre tais denominações e, neste sentido, o significado de uma palavra é o objeto que ela substitui. A crítica de Wittgenstein à concepção referencial da linguagem não se dá no sentido de negá-la, mas, antes, de chamar a atenção para o fato de que o uso referencial é apenas um dos usos da linguagem e, portanto, não descreve todos seus domínios (WITTGENSTEIN, 2000). Segundo o filósofo:

\footnotetext{
Santo Agostinho descreve, podemos dizer, um sistema de comunicação; só que esse sistema não é tudo aquilo que chamamos de linguagem. E isso dever ser dito em muitos casos em que se levanta a questão: "Essa apresentação é útil ou não?". A resposta é, então: "Sim, é útil; mas apenas para esse domínio estritamente delimitado, não para o todo que você pretendia apresentar" (WITTGENSTEIN, 2000, §3).
}

Uma concepção de linguagem que se restrinja a seu uso referencial, isto é, na qual cada palavra faz referência a um objeto do mundo e desconsidera seus diversos usos, constitui uma imagem da linguagem: a imagem agostiniana ou tractariana da linguagem. Tal imagem pode conduzir os filósofos à confusões como, por exemplo, a de se perguntar qual a referência da palavra amor no mundo e, uma vez que não podem apontar um objeto físico como referente desta palavra, a de conceber que tal referente seja um certo estado mental em que uma pessoa se encontra. A confusão tem sua origem na ideia de que alguma coisa deva necessariamente corresponder à palavra amor.

Wittgenstein explicita a relevância desta reflexão para os problemas filosóficos comentando uma pergunta que se poderia formular acerca do tempo, a saber, "Para onde 
vai o presente quando se torna passado, e onde está o passado?". Wittgenstein diz que "Eis uma das fontes mais fecundas de desconcerto filosófico" (MONK, 1995). Segundo Monk (1995):

Perguntas como esta, afirma Wittgenstein, surgem porque nosso simbolismo equivocadamente nos leva a certas analogias (neste caso, a analogia entre um evento passado e uma coisa, a analogia entre dizer "Algo aconteceu" e "Algo veio a mim"). Do mesmo modo, "somos inclinados a dizer que 'agora' e 'seis horas' referem-se a pontos no tempo. Este uso das palavras produz um desconcerto que poderia ser expresso na pergunta 'O que é o agora?' [...] Aqui, referindo-se essencialmente ao problema do tempo em santo Agostinho (MONK, 1995, pg. 311).

As confusões a que os filósofos são levados pela imagem agostiniana da linguagem são fruto da coisificação de nossos conceitos, da naturalização de uma necessidade de que existam entidades às quais nossos conceitos devam corresponder. $\mathrm{O}$ principal objetivo do segundo Wittgenstein é desfazer essas confusões, ao mostrar que tais conceitos podem operar sem necessariamente apresentar um referente. Para se ter uma ideia do que seria desfazer essas confusões, apresentamos um problema do campo da saúde na qual Wittgenstein trabalhou com especial interesse. Trata-se do diagnóstico de "choque" relativo às vítimas de guerra. Um certo Dr. Grant, da Unidade de Pesquisas Clínicas do Medical Research Council, escreve um memorando no qual diz:

A experiência recente com vítimas de ataques aéreos mostra que, apesar de todo o trabalho já realizado, sobretudo durante a última guerra, pouco se sabe acerca da natureza e tratamento do choque traumático ou de ferimento. Em primeiro lugar, existe na prática uma ampla variação na aplicação do diagnóstico de "choque". Não sabemos ainda predizer e muitas vezes ficamos em dúvida quanto ao tratamento. Ademais, a falta de uma base comum de diagnóstico torna impossível avaliar a eficácia dos diversos métodos de tratamento adotados.

Há, portanto, bons motivos para a opinião de que seria melhor evitar o diagnóstico de "choque" e substituí-lo por um registro preciso e completo do estado e progresso do paciente paralelamente ao seu tratamento (MONK, 1995, pg. 397).

A maneira de Grant lidar com o problema interessou em muito Wittgenstein, isso pelo fato de ter sido expresso em termos de uma dificuldade conceitual como obstáculo na compreensão e tratamento de um problema de ordem prática. Ademais, esta abordagem do problema do diagnóstico de "choque" apresenta paralelos com o tratamento de Hertz acerca do problema da "força" na física. Segundo Monk (1995):

... Hertz propusera que, em vez de se dar uma resposta direta à pergunta "O que é força?", o problema deveria ser enfrentado reformulando-se a física newtoniana sem usar "força" como um conceito básico. Durante toda a vida, Wittgenstein considerou a solução de Hertz um modelo perfeito de como dissipar a confusão filosófica e costumava citar - como 
uma afirmação de sua meta filosófica - a seguinte frase da introdução de Prinzipen der Mechanik:

Quando essas excruciantes contradições são removidas, a questão da natureza da força não terá sido resolvida; mas nossa mente, não mais exasperada, deixará de fazer perguntas improcedentes.

(MONK, 1995, pg. 397).

Para escapar das confusões oriundas de uma concepção de linguagem que a restringe a seu uso referencial, Wittgenstein apresenta uma abordagem na qual as práticas às quais a linguagem se liga são fundamentais para a constituição dos sentidos. Com a finalidade de destacar o papel das práticas com as quais a linguagem se relaciona, Wittgenstein descreve situações hipotéticas nas quais uma linguagem simplificada, primitiva, é empregada. Tais situações são chamadas, pelo filósofo, de Jogos de Linguagem e um de seus exemplos é o jogo de linguagem entre um construtor e seu ajudante. Nas palavras do filósofo:

... a linguagem deve servir para o entendimento de um construtor A com um ajudante B. A executa a construção de um edifício com pedras apropriadas; estão à mão cubos, colunas, lajotas e vigas. B passa-lhes as pedras, e na sequência em que A precisa delas. Para esta finalidade, servem-se de uma linguagem constituídas das palavras "cubos", "colunas", "lajotas", "vigas". A grita essas palavras; - B traz as pedras que aprendeu a trazer ao ouvir esse chamado (WITTGENSTEIN, 2000, §2).

O jogo de linguagem do construtor e de seu ajudante nos mostra uma linguagem primitiva em uso, ou seja, um conjunto de palavras que através de determinadas regras de ação viabilizam a comunicação entre os dois para a construção de um edifício. Logo após descrever este jogo de linguagem, Wittgenstein sugere que imaginemos que esta linguagem primitiva seja toda a linguagem de um povo para, em seguida, refletir sobre a educação das crianças pertencentes a esta comunidade. "As crianças são educadas para executar essas atividades, para usar essas palavras ao executá-las, e para reagir assim às palavras dos outros." (WITTGENSTEIN, 2000). Segundo o filósofo:

\footnotetext{
Uma parte importante deste treinamento consistirá no fato de que quem ensina mostra os objetos, chama a atenção da criança para eles, pronunciando então uma palavra, por exemplo, a palavra "lajota", exibindo essa forma. (Não quero chamar isto de "elucidação ostensiva" ou "definição", pois na verdade a criança ainda não pode perguntar sobre a denominação. Quero chamar de "ensino ostensivo das palavras". [...] Esse ensino ostensivo das palavras, pode-se dizer, estabelece uma ligação associativa entre a palavra e a coisa... (WITTGENSTEIN, 2000, § 6).
}

A ligação entre linguagem e mundo se dá por meio de paradigmas ou da apresentação de modelos a um aprendiz. Um paradigma é uma técnica de uso da linguagem na qual fragmentos do mundo empírico são apresentados como modelos de aplicação de palavras (MORENO, 1995). Assim sendo, no ensino ostensivo dos nomes de objetos às crianças, 
utilizamos uma coleção, previamente organizada, de objetos como meio de apresentação de palavras, sugerindo critérios para suas aplicações corretas (MORENO, 1995).

É importante salientar que, para Wittgenstein, os objetos utilizados como meio de apresentação de palavras já pertencem à linguagem nesta fase preparatória. Portanto, no lugar de conceber que a palavra faz referência a objetos do mundo, concebe-se que os objetos é que são introduzidos no interior da linguagem e passam a ser instrumentos da linguagem (MORENO, 1995). Wittgenstein, fazendo alusão à tabela de cores utilizada por um construtor (A) para solicitar materiais a seu ajudante (B), afirma:

\footnotetext{
Quanto aos modelos de cor que $\mathrm{A}$ mostra a $\mathrm{B}$, - pertencem à linguagem? Ora, como queira. À linguagem de palavras não pertencem; mas quando digo a alguém: "Pronuncie a palavra 'a"', você incluirá com certeza este segundo 'a' na frase. E no entanto isso desempenha um papel bem semelhante ao modelo de cores no jogo de linguagem (8); é, a saber, um modelo daquilo que o outro deve dizer.

É mais natural, e leva o menos possível à confusão, se incluirmos o modelo nas ferramentas da linguagem (WITTGENSTEIN, 2000, § 16).
}

Moreno esclarece que não apenas os objetos podem ser apresentados como modelos de aplicação de palavras, mas também determinadas práticas de uso da linguagem. Segundo Moreno (1995):

... para dar conta das ligações entre linguagem e mundo, sem incorrer nas "confusões" da imagem agostiniana, é preciso considerar, como diz Wittgenstein, "as práticas de uso da linguagem", ou ainda, "a linguagem e as práticas com as quais ela se liga" enquanto instrumentos que, assim como as palavras, pertencem à linguagem - e, além disso, enquanto mediação inevitável que estabelece aquelas ligações, desde as mais primitivas até as mais complexas (MORENO, 1995, pg. 23).

Podemos dizer que uma criança, de nosso povoado fictício, compreende a palavra "lajota" se, ao escutá-la, age da maneira que esperamos, ou seja, nos traz uma lajota. Tal compreensão da palavra é viabilizada através do ensino ostensivo das palavras mediante uma determinada lição. Caso o ensino ostensivo ocorresse de outra maneira, com outras lições, a compreensão resultante poderia ser completamente diferente (WITTGENSTEIN, 2000). Wittgenstein abandona a ideia de uma relação direta e definitiva entre palavras e objetos do mundo para, no lugar, assumir que tal ligação se dá por meio de técnicas convencionais de mediação, nas quais fragmentos do mundo empírico são incorporados como instrumentos da linguagem (MORENO, 1995). Nas palavras de Moreno (1995):

... as ligações "primitivas" ou "preparatórias" entre signo e objeto são, na verdade, ligações entre signos e instrumentos da linguagem realizadas através de técnicas convencionais. Isto mostra que mesmo as ligações mais primitivas entre linguagem e mundo não são jamais imediatas, nem definitivas e nem uniformes. Elas serão, pelo contrário, sempre mediatizadas 
por práticas ligadas à linguagem; serão sempre fruto de convenções, isto é, não serão necessárias, não terão fundamentos últimos; serão sempre multiformes, isto é, serão relativas a jogos variados (MORENO, 1995, pg. $22)$.

Uma conclusão notável desta concepção de linguagem é que a relação entre linguagem e mundo deixa de apresentar apenas uma possibilidade, visto que no Tractatus linguagem e mundo apresentam a mesma forma lógica, para apresentar uma vasta gama de possibilidades mediatizadas por diferentes técnicas de ensino ostensivo de palavras.

Segundo Moreno (2015, pg. 101), o ensino ostensivo possui a função de introduzir normas para a incorporação significativa de elementos do mundo à linguagem, quando dizemos, por exemplo, "isto é verde" estamos apresentando um elemento do mundo como candidato à aplicação desta palavra, enquanto que a definição define o sentido do que é ser um objeto, quando dizemos, por exemplo, "verde é uma cor" estamos apresentando o contexto de aplicação da palavra "verde".

Moreno (2015) evidencia, a partir destas duas etapas elementares de articulação do sentido, "uma nova concepção do conceito de condição de possibilidade que emerge dos processos de integração linguística da realidade e de definição do objeto." e acrescenta que:

\begin{abstract}
As duas etapas elementares de articulação do sentido - i.e., a atribuição de nomes como etiquetas e a definição de seu sentido - correspondem a um nível exclusivamente convencional de introdução de normas, sem qualquer necessidade - é sempre possível aceitá-las ou não. A etapa seguinte será o resultado do que Wittgenstein denomina de "cálculo com a linguagem", a saber, a criação de expressões linguísticas portadoras de necessidade - é o nível propriamente proposicional. É quando a significação parece soar como uma definição de essência - i.e., quando parece não poder ser negada, nem, muito menos, pensada de modo diferente. [...] Começamos aceitando convenções iniciais e passamos a pensar relações necessárias (MORENO, 2015, pg. 102).
\end{abstract}

Ainda de acordo com Moreno (2015), seria possível pensar em níveis de elaboração do sentido. Enquanto o ensino ostensivo e a definição ostensiva das palavras apresentam caráter convencional, no qual o aprendiz é levado a aceitar normas de aplicação de palavras mediante variadas técnicas de apresentação, o nível proposicional teria caráter de necessidade, uma vez que seu sentido é condicionado pelas normas previamente aceitas nas etapas preparatórias. Nas palavras de Wittgenstein (2000):

Denominar e descrever não se encontram na verdade num único nível: o denominar é uma preparação para a descrição. O denominar não é ainda nenhum lance no jogo de linguagem, - tampouco quanto o colocar uma figura de xadrez no lugar é um lance no jogo de xadrez (WITTGENSTEIN, $2000, \S 49)$.

Wittgenstein utiliza uma analogia entre a linguagem e o jogo de xadrez para esclarecer os diferentes níveis em que se encontram denominar e descrever. Enquanto a 
atividade de atribuir nomes, por exemplo, a objetos, ações e sentimentos situa-se num nível preparatório para o uso da linguagem, a descrição já é um determinado uso da linguagem possibilitado pelo ensino ostensivo e pelas definições.

Visto de outra forma, na etapa preparatória são introduzidas normas de uso das palavras através de paradigmas assim como, no xadrez, apresenta-se os nomes e movimentos de cada uma de suas peças. Enquanto isso, no uso descritivo, faz-se uso das normas da linguagem para falar sobre o mundo assim como, no xadrez, disputa-se uma partida respeitando as regras estabelecidas anteriormente.

Wittgenstein, nas Investigações Filosóficas, destaca o papel das práticas envolvidas com a linguagem afirmando que, nesta nova concepção, o significado da palavra é o seu uso. Segundo o filósofo:

Pode-se, para uma grande classe de casos de utilização da palavra "significação" - se não para todos os casos de sua utilização -, explicá-la assim: a significação de uma palavra é seu uso na linguagem (WITTGENSTEIN, $2000, \S 43)$.

Para compreender melhor a importância do uso da linguagem para a significação, assim como seu estatuto de fundamento, na filosofia do segundo Wittgenstein, apresentamos algumas reflexões do filósofo acerca da teoria e da religião. Wittgenstein responde a pergunta "A fala é essencial à religião?" da seguinte maneira:

Posso bem imaginar uma religião em que não haja proposições doutrinais e em que, portanto, não haja fala. Obviamente, a essência da religião não pode ter nada a ver com o fato de haver fala. Ou melhor, quando as pessoas falam, então isso em si é parte de um ato religioso, e não uma teoria. Portanto, também não importa a mínima se as palavras usadas são verdadeiras, falsas ou um contra-senso.

Na religião, o falar também não é metafórico; de outra forma teria de ser possível dizer as mesmas coisas em prosa (MONK, 1995, pg. 278).

Em uma correspondência com um amigo, Wittgenstein observa que "Se for para você e eu vivermos uma vida religiosa, não há de ser por falarmos muito sobre religião e sim porque nossa maneira de viver é diferente." e sugere que a frase "No princípio havia o ato" de Goethe em Fausto poderia servir de lema para toda sua filosofia posterior ao Tractatus (MONK, 1995). Segundo Monk (1995):

O ato, a atividade, é primordial; não é explicado nem justificado a partir de qualquer teoria que possamos ter a respeito. Isso é tão verdadeiro para a linguagem e para a matemática como para a ética, a estética e a religião. [...] O vínculo entre uma palavra e seu significado deve ser encontrado não na teoria, mas na prática, no uso da palavra. E o vínculo direto entre uma regra e sua aplicação, entre a palavra e o ato, não poderia ser esclarecido mediante outra regra; tem de ser visto: "No caso, ver é de importância essencial; enquanto não vemos o novo sistema, ele não existe para nós" (MONK, 1995, pg. 279-280). 
Se, de um lado, somos introduzidos à linguagem por meio de técnicas convencionais de apresentação de regras de uso das palavras, por outro, estas técnicas convencionais são fundamentadas em nosso hábito diante das palavras e do mundo, em nossa forma de vida. Nas palavras de Janik e Toulmin (1991):

\begin{abstract}
Os conceitos e categorias que realmente empregamos podem não fornecer a única base concebível ou consistente para uma experiência coerente e descritível do mundo; mas representam, de fato, um equilíbrio legítimo, resultante de uma sequência de escolhas interligadas, nenhuma das quais, no contexto prático de decisão, poderia ter sido feita de forma diferente, exceto por um preço muito alto (JANIK; TOULMIN, 1991, pg. 269).
\end{abstract}

Podemos afirmar, então, que a concepção de "forma lógica" é deixada de lado pelo filosofo e que a significação passa a ser concebida em termos de sua função em determinadas formas de vida. E, ainda, que, apesar de seu caráter convencional, as regras de uso resultam de diversas escolhas realizadas por nossa comunidade em face de diversos fatores condicionantes e ao longo do tempo. Dessa forma, seria um erro dizer que, por serem convencionais, nossas regras de uso poderiam ser quaisquer outras. Tal afirmação negligenciaria os contextos práticos em que tais escolhas se mostraram úteis e necessárias.

A partir do que foi exposto anteriormente, sintetizaremos a concepção de linguagem do segundo Wittgenstein dizendo que, para ele, a linguagem é compreendida como "um caleidoscópio de situações em que manipulamos palavras, os jogos de linguagem", como "uma forma de vida" e tratada "relativamente às situações em que sempre está inserida" (MORENO, 1995). Isso significa que em diferentes formas de vida encontraremos diferentes regras de uso para as palavras, introduzidas através de diferentes dinâmicas de ensino na qual a variedade contrasta com a uniformidade da imagem agostiniana (MORENO, 1995).

No Tractatus, a significação se dava por meio da correspondência entre as palavras da linguagem e os objetos do mundo, sendo que, linguagem e mundo, compartilhavam uma forma lógica. Nas Investigações Filosóficas, ocorre um alargamento do domínio da significação, no qual as relações entre linguagem e mundo se dão através de uma gramática, isto é, um conjunto de regras de uso das palavras que condicionam e possibilitam o uso significativo da linguagem (MORENO, 1995). A gramática é, portanto, o resultado da etapa preparatória para o uso da linguagem por meio do ensino ostensivo e da definição ostensiva e, posteriormente, se complexifica pelos próprios usos efetivos da linguagem, isto é, a gramática "conserva seu estatuto de condição formal e a priori, relativamente ao que condiciona, e revela o seu modo de elaboração e de funcionamento, que é a parte post, ou seja, no decurso do uso da linguagem" (MORENO, 2015).

Refletindo a partir dos diferentes níveis de elaboração do sentido, podemos distinguir as proposições em duas categorias, a saber, proposições gramaticais e proposições empíricas. As proposições empíricas são aquelas que utilizamos para descrever o mundo e que, portanto, 
devem ser passíveis de verificação através de algum procedimento de confronto com o mundo empírico. Enquanto isso, as proposições gramaticais são aquelas que possibilitam os diferentes usos da linguagem de forma significativa e que constituem os próprios critérios de sentido e significado em nossa linguagem. No entanto, a distinção entre proposições gramaticais e empíricas não era compreendida como fixa, mas relativa a uma prática. Segundo Monk (1995):

Wittgenstein caracterizava de muitas maneiras as proposições gramaticais - "proposições auto-evidentes", "proposições formadoras de conceitos" etc. - mas uma das mais importantes consistia em descrevê-las como regras. Ao enfatizar a fluidez da distinção gramatical / empírica, ele estava chamando a atenção para o fato de que a formação de conceitos e, consequentemente, o estabelecimento de regras para o que faz e o que não faz sentido afirmar - não é algo fixo pelas leis imutáveis da forma lógica (como acreditara no Tractatus), e sim algo sempre associado a um costume, uma prática. Desse modo, outros costumes e outras práticas irão pressupor conceitos diferentes daqueles que nós consideramos úteis. Isso, por sua vez, envolveria a aceitação de regras diferentes (determinando o que faz e o que não faz sentido) daquelas adotadas por nós (MONK, 1995, pg. 415).

Através desta categorização de proposições, Wittgenstein reflete sobre o significado de saber e ter certeza. Segundo o filósofo, saber se relacionaria com as proposições empíricas no sentido de que seria fruto de um processo de verificação a partir do qual se decide entre uma proposição ou sua antítese em confronto com o mundo. Aqui, é fundamental que tanto afirmação quanto negação de uma proposição empírica tenham sentido e sejam distinguidas quanto a seu valor de verdade, verdadeira ou falsa, quando confrontadas com o mundo. Enquanto isso, ter certeza se relacionaria com as proposições gramaticais que não são passíveis de verificação e não são julgadas por seu valor de verdade mas, antes, são critérios do que faz ou não faz sentido e, portanto, sua negação não parece aceitável, soa como absurdo. Segundo Monk (1995):

A ideia é que, se o contrário de uma proposição fizer sentido, então esta proposição pode ser considerada uma hipótese empírica, cuja veracidade ou falsidade dependerá da maneira como as coisas estão postas no mundo. Mas se o contrário de uma proposição não fizer sentido, então esta proposição é descritiva não do mundo, mas de nosso arcabouço conceitual; e é portanto, uma parte da lógica (MONK, 1995, pg. 495).

Wittgenstein, nas Investigações Filosóficas comenta que:

Para uma compreensão por meio da linguagem, é preciso não apenas um acordo sobre as definições, mas (por estranho que pareça) um acordo sobre os juízos. Isto a lógica parece guardar; mas não guarda" (WITTGENSTEIN, 2000 apud MONK, 1995, 495). 
Tal acordo de juízos seriam as proposições gramaticais incorporadas a partir da etapa preparatória ao uso da linguagem e o próprio uso efetivo das mesmas. É considerando a existência de proposições gramaticais que Wittgenstein desconsidera o ceticismo. Em suas palavras:

\begin{abstract}
"O ceticismo não é irrefutável, mas manifestamente um contra-senso, se pretende duvidar onde não se pode perguntar" [TLP 6.51] [...] "Certas proposições pertencem ao meu 'quadro de referências'. Se eu tivesse que renunciar a elas, não seria capaz de julgar nada." (MONK, 1995, pg. 489).
\end{abstract}

Wittgenstein utiliza a analogia do rio e seu leito para esclarecer o papel das proposições gramaticais e das proposições empíricas. Nessa analogia, as proposições gramaticais constituiriam o leito do rio que, sendo mais sólido e estando mais ao fundo, forneceria condições para que a água do rio corresse sobre si. Já as proposições empíricas seriam a água do rio cujo movimento está condicionado e possibilitado pelo leito do rio que a sustenta. (MONK, 1995).

É importante destacar que a gramática é constituída através de relações internas à linguagem e, portanto, possui autonomia com relação ao mundo externo. Os fragmentos do mundo empírico utilizados no ensino ostensivo das palavras são incorporados à linguagem e se relacionam através de regras de uso com um conjunto de palavras e atividades. A autonomia da gramática pode ser melhor compreendida quando analisamos o caso dos jogos de linguagem das cores ou das sensações. Segundo Moreno (1995):

\begin{abstract}
Assim como em todos os jogos de linguagem, os conceitos de sensações e de cor são construídos no interior de práticas sociais, como partes de instituições: dependem de comportamentos habituais, de "expressões naturais" que fazem parte da gramática das expressões linguísticas. [...] Por outro lado, não é a existência de cores ou de entidades que "justifica" o emprego que fazemos das expressões correspondentes. Os critérios de verdade para tais expressões estão na linguagem e não fora dela (MORENO, 1995, pg. 62).
\end{abstract}

O caso da dor é interessante devido à impossibilidade de experimentarmos a dor alheia, ou seja, não podemos estabelecer critérios para a aplicação da palavra dor que levem em consideração características essenciais da sensação de dor. No entanto, conseguimos nos comunicar utilizando o conceito de dor a despeito de nossa incapacidade de acessar as sensações alheias. As regras de utilização destes conceitos são constituídas levando-se em consideração certas expressões corporais que identificamos como as de alguém com dor e não propriedades imanentes à própria dor (MORENO, 1995, 63).

Apesar de afirmar que a gramática de uso dos conceitos de cores e sensações independem da existência destes, isso não quer dizer que os mesmos não façam parte da gramática desses jogos de linguagem. Segundo Moreno (1995): 
O fato de ser irrelevante a existência extralinguística de sensações e de cores não implica, para Wittgenstein, que elas não façam parte da gramática dos jogos, ou que caiam fora de consideração. Se não podemos identificar objetos fora da linguagem, através de propriedades características que lhes fossem imanentes, isso implica, simplesmente, que nada podemos dizer a seu respeito e descrevê-los, a não ser no interior da linguagem através de conceitos: vivemos no mundo das sensações, mas falamos através de conceitos (MORENO, 1995, pg. 63).

As sensações de dor e de cor são apresentadas como modelos de aplicação de palavras, como dor ou verde, durante o ensino ostensivo mesmo sem que tais sensações correspondam exatamente àquilo que quem ensina sente e chama por tais nomes. Assim, pode-se dizer a uma criança que chora e contorce seu corpo que está com dores sem, no entanto, possuir critérios de verificação para a existência dessa dor que transcendam a constatação de que ela se comporta como alguém que sente dores. Ou seja, a criança considerará sua sensação privada como um modelo, um fragmento empírico, daquilo que podemos chamar dor.

\subsection{Concepção de filosofia no segundo Wittgenstein}

Para o segundo Wittgenstein, o papel da filosofia não é o de propor novas teorias explicativas ou descritivas do mundo, pois seus problemas decorrem do uso incorreto da linguagem e isso não demandaria soluções mas sim dissoluções. A filosofia seria, então, uma atividade, um método, no qual seriam reunidas lembranças daquilo que já conhecemos com a finalidade de que, uma vez que tenhamos lembrado, as confusões se dissipariam (MONK, 1995). Em citação direta feita por Monk (1995):

O que descobrimos em filosofia é banal; não nos ensina fatos novos, somente a ciência faz isso. Mas um compêndio adequado dessas banalidades é tremendamente difícil, e de imensa importância. A filosofia é, na realidade, o compêndio das banalidades (MONK, 1995, pg. 272).

A diferença entre filosofia e ciência, apontada por Wittgenstein, reside no fato de que o objetivo da ciência era o progresso e, portanto, esta se apresentava como construtiva e, assim sendo, seu apreço pela clareza era devido a possibilidade de construção a partir da compreensão clara. Enquanto isso, sua proposta de filosofia consistia em valorizar a clareza em si mesma e, assim, evitar as confusões. Seu interesse era, em suas palavras, "ter uma visão perspícua dos alicerces de possíveis edifícios" enquanto o interesse dos cientistas era o de "construir um edifício." (MONK, 1995). Essa visão perspícua da gramática dos usos das palavras somente se poderia mostrar e não descrever. Segundo Monk (1995):

As "relações internas" estabelecidas pela gramática não são suscetíveis de ulterior exame ou justificação; só podemos dar exemplos de onde as regras são usadas corretamente e onde não são, e dizer: "Olhe - você não vê a 
regra?". Por exemplo, a relação entre a partitura e a execução musical não pode ser aprendida causalmente (como se, misteriosamente, determinada partitura fosse a causa de interpretarmos a peça de certa maneira) nem as regras que unem as duas podem ser descritas de modo exaustivo - pois, dada certa interpretação, é possível fazer com que qualquer execução concorde com a partitura. No final, temos simplesmente que "ver a regra nas relações entre execução e partitura". Se não conseguimos ver, nenhuma espécie de explicação a tornará compreensível; e se conseguimos, teremos chegado a um ponto em que as explicações são supérfluas - não precisaremos de nenhum tipo de explicação "fundamental" (MONK, 1995, pg. 275)

Para mostrar as regras de uso das palavras, Wittgenstein enfatizou a capacidade de ver correlações entre os diferentes usos das palavras apresentados como exemplos. Seu método, muito provavelmente, foi inspirado em O declínio do Ocidente de Spengler e em A metamorfose das plantas de Goethe (MONK, 1995). Spengler tentou compreender a história buscando analogias entre diferentes épocas culturais e não por meio de uma série de leis assim como Goethe tentou compreender as plantas sem recorrer a um mecanismos causal como era o caso da Evolução de Darwin. Wittgenstein, por sua vez, tinha a intenção de apresentar a morfologia do uso de uma expressão. Em citação direta de Monk (1995):

\begin{abstract}
Temos o hábito, sempre que percebemos semelhanças, de buscar uma origem comum para elas. O impulso de ir ao encalço desses fenômenos até sua origem no passado expressa em si mesmo certo estilo de pensar que, por assim dizer, reconhece apenas um único esquema para tais similaridades - a saber, a disposição de uma série no tempo. (E isso presumivelmente vinculado a uma singularidade dos esquemas causais.) Mas Goethe mostra que esta não é a única forma possível de concepção. Sua concepção de planta inicial não implica hipótese alguma referente ao desenvolvimento temporal do reino vegetal como a de Darwin. [...] É precisamente isso que estamos fazendo aqui. Estamos confrontando uma forma de linguagem com seu ambiente, ou transformando-a na imaginação a fim de obter uma visão panorâmica do espaço em que a estrutura da nossa linguagem se coloca (MONK, 1995, pg. 276).
\end{abstract}

O interesse de Wittgenstein pelo método morfológico reside no fato de que este não possui ânsia de generalidade, ou seja, não procura encontrar uma lei, um único esquema, segundo o qual se poderia explicar uma diversidade a partir de uma origem comum e determinados mecanismos de evolução mas, antes, apresenta de maneira panorâmica as diversas formas e suas correlações permitindo, inclusive, conjecturar sobre formas intermediárias àquelas que já se conhece.

Wittgenstein resumiu seu método filosófico dizendo que consiste no exato oposto do método de Sócrates. Segundo ele, Sócrates procurava a essência das coisas, como por exemplo do conhecimento, algo comum a todas as coisas subsumidas sob um termo genérico. No lugar de essência, Wittgenstein utilizava a ideia, mais flexível, de Semelhanças de familia (MONK, 1995, 305). Nas palavras de Wittgenstein: 
Considere, por exemplo, os processos que chamamos de "jogos". Refiro-me a jogos de tabuleiro, de cartas, de bola, torneios esportivos etc. O que é comum a todos eles? Não diga: "Algo deve ser comum a eles, senão não chamariam 'jogos"', - mas veja se algo é comum a eles todos. Pois, se você os contempla, não verá na verdade algo que fosse comum a todos, mas verá semelhanças, parentescos, e até toda uma série deles. Como disse: não pense, mas veja! - Considere, por exemplo, os jogos de tabuleiro, com seus múltiplos parentescos. Agora passe para os jogos de cartas: aqui você encontra muitas correspondências com aqueles da primeira classe, mas muitos traços comuns desaparecem e outros surgem. Se passarmos agora aos jogos de bola, muita coisa comum se conserva, mas muitas se perdem (WITTGENSTEIN, 2000, § 66).

Para Wittgenstein, o conceito de jogos se refere a um conjunto de processos, ou práticas, simultaneamente aparentados entre si e diversos em algum grau. Seu esforço consiste em apresentar as características próprias deste conjunto sem tentar reduzi-lo a uma definição ou critério de classificação. No lugar, pretende ressaltar as semelhanças e diferenças entre o que normalmente denominamos "jogos" descrevendo, assim, a multiplicidade de nossa linguagem em vez de fazer uma teoria sobre ela. Segundo Wittgenstein:

Sentimo-nos por exemplo inclinados a pensar que deve existir algo de comum a todos os jogos, e que esta propriedade comum é a justificação para a aplicação do termo geral "jogo" aos diversos jogos; ao passo que os jogos formam uma família cujos membros tem semelhanças. Alguns tem o mesmo nariz, outros as mesmas sobrancelhas e outros ainda a mesma maneira de andar; e estas semelhanças sobrepõem-se (MONK, 1995, pg. 305).

Wittgenstein pretendia, com esta morfologia do uso de uma expressão, mostrar a diversidade de formas em que empregamos a linguagem, isso com a finalidade de abandonar a maneira confusa de examinar as coisas que, segundo ele, era resultado da "dieta pobre de exemplos" dos filósofos (MONK, 1995). Essa tal "dieta pobre de exemplos" seria praticada pelos filósofos que, influenciados pelo método científico e na ânsia por generalizações, permitiam-se considerar um pequeno conjunto de exemplos a partir do qual tiravam conclusões gerais, essências. Em citação direta de Monk (1995):

Os filósofos tem sempre presente o método da ciência e são irresistivelmente tentados a levantar questões e a responderem-nas do mesmo modo que a ciência. Esta tendência é a verdadeira fonte de metafísica, e leva o filósofo a toda obscuridade (MONK, 1995, pg. 306).

Diante de tudo o que dissemos até aqui, cabe uma breve consideração sobre o principal alvo do método do segundo Wittgenstein. Wittgenstein, em sua segunda fase, procurava realizar a terapia filosófica de sua concepção de linguagem anterior, a saber, a concepção referencial da linguagem expressa no Tractatus, a imagem agostiniana. Para dar conta de realizar a terapia filosófica desta concepção, o filósofo analisou as diferentes formas através das quais relacionamos a linguagem e os objetos do mundo, bem como as 
diferentes formas que empregamos nossa linguagem. Os jogos de linguagem serviram bem a este propósito:

\begin{abstract}
O estudo das aplicações "primitivas" da linguagem permite, como diz Wittgenstein, "dissipar a bruma" que envolve o conceito de significação ao mesmo tempo que "os claros e simples" jogos de linguagem - que são propostos enquanto "objetos de comparação" - permitem "lançar luz sobre as relações de nossa linguagem" [...] onde "pode-se ter uma visão de conjunto clara da finalidade e do funcionamento das palavras" (MORENO, 1995, pg. 22).
\end{abstract}

O objetivo da terapia filosófica não está em aperfeiçoar nosso uso da linguagem para que melhor descreva o mundo, nem em falar sobre o mundo empírico e, tampouco, sobre princípios do conhecimento. Seu tema principal é a existência de certas imagens que, apresentando caráter de necessidade, nos impedem de conceber algo de maneira diferente e apresentam dificuldades ao pensamento. Segundo Moreno (1995):

Temos, então, duas características das imagens: correspondem, por um lado, às más interpretações de nossas expressões habituais conduzindo, assim, a dificuldades insolúveis; por outro lado, possuem a força da necessidade (MORENO, 1995, pg. 37).

As más interpretações de nossas expressões habituais decorre, por exemplo, quando somos levados a definir um sentido inequívoco ao uso de nossas palavras, como é o caso da imagem agostiniana da linguagem que ao afirmar que para cada palavra há uma referência no mundo. Esta imagem da linguagem nos leva a problemas sem solução como, mencionado anteriormente, o de nos perguntarmos à que corresponde a palavra "amor". Eis, segundo Moreno (1995), o objeto da terapia filosófica:

\footnotetext{
A descrição gramatical não tematiza objetos do mundo, ou fatos, nem princípios do conhecimento; seu tema é a necessidade contida nas imagens: "não podemos pensar de outra maneira, pois deve ser assim", é uma situação conceitualmente típica em que as imagens mostram sua força (MORENO, 1995, pg. 48).
}

Esta nova concepção de atividade filosófica apresenta algumas características cuja síntese podem ajudar a compreender o espírito da obra do segundo Wittgenstein assim como o espírito em que este trabalho foi desenvolvido. Em primeiro lugar, os diferentes exemplos de uso das palavras apresentados servem como objetos de comparação com a finalidade de salientar analogias e diferenças internas entre aplicações de palavras e conceitos. Em segundo lugar, a descrição gramatical visa ampliar o domínio da significação de determinadas palavras no lugar de restringi-lo através de regras prescritivas. Por último, revisita determinados usos da linguagem com a finalidade de esclarecer confusões mediante a tomada de consciência das nuances presentes nas regras de usos efetivos de nossa linguagem e desfazer os efeitos de visões dogmáticas dos conceitos (MORENO, 2005). 


\subsection{O uso dos conceitos e o surgimento das imagens}

Segundo Moreno (1995, pg. 41) podemos sentir a presença de duas imagens em toda a atividade filosófica de Wittgenstein. Inicialmente, estas imagens teriam guiado sua atividade filosófica e, posteriormente, suas forças teriam inspirado e sido usadas como justificativa para a terapia filosófica. Segundo Moreno (1995):

A primeira delas corresponde à concepção agostiniana da significação, segundo a qual a linguagem tem uma única função: exprimir pensamentos sobre objetos: casas, mesas, desejos, cores etc. Esta imagem traz consigo três consequências para nosso pensamento: 1. Quando um som substitui um objeto, este som torna-se significativo, torna-se palavra; 2. Na ausência de objetos, os sons não tem significação; 3 . A existência de palavras implica a existência de objetos. [...] A segunda imagem corresponde ao ideal de exatidão, ao exercício da lógica como meio para a construção de linguagens exatas. A força desta imagem consiste em fazer-nos pensar que há uma hierarquia de diferentes simbolismos, e que a medida das diferenças é também o critério de sua incomunicabilidade. Esta imagem foi muito influente para o sistema do Tractatus à medida que a noção do lógico não se reduz aos cálculos formais efetivos: estes são apenas um instrumento conceitual para exemplificar e exibir a forma lógica que caracteriza uniformemente toda e qualquer linguagem significativa. Ela marcou sua influência enquanto desvinculou a reflexão sobre a significação do solo no qual repousam os sistemas simbólicos e, mais profundamente, guiou o pensamento do filósofo no sentido de procurar a "essência última da linguagem”, fixa, imutável (MORENO, 1995, pg. 41).

As imagens, de forma geral, surgem ao longo do processo de uso dos conceitos que aplicamos cotidianamente ${ }^{1}$, ou seja, não costumam surgir na etapa preparatória da linguagem, onde são introduzidos os paradigmas que fornecem as condições mínimas para o uso das palavras, mas durante a utilização efetiva dos conceitos aprendidos em situações concretas de aplicação. Segundo Moreno (1995):

Ora, os conceitos são um dos resultados do complexo processo de uso das palavras; a descrição gramatical parte de palavras, mas visa os conceitos. É justamente no nível dos conceitos que surgem as imagens - pois não é com palavras que as imagens entram nos jogos de linguagem (MORENO, 1995, pg. 27).

Durante a etapa preparatória para o uso da linguagem são estabelecidas relações entre palavras e objetos do mundo empírico através de diferentes técnicas linguísticas. Estas relações constituem as regras de aplicação das palavras, a gramática das palavras. A gramática é a condição de possibilidade do uso descritivo da linguagem, ou seja, podemos aplicar uma palavra para descrever nossa experiência porque estamos de acordo com as regras de sentido das palavras que utilizamos. Assim, enquanto as proposições empíricas são utilizadas para descrever a experiência a partir de um conjunto de convenções de uso

1 No caso da matemática, por exemplo, as imagens surgem já na apresentação de uma demonstração, ou seja, já no nível convencional da introdução de normas. 
da linguagem (gramática), as proposições gramaticais exprimem algumas das regras que fundamentam nossa linguagem ou, em outras palavras, revelam as convenções a partir das quais fazemos uso, com sentido, da linguagem.

No entanto, devido à aparência uniforme das proposições gramaticais e empíricas podemos confundi-las e acreditar que todas as proposições possuem a mesma função, por exemplo, descrever o mundo empírico quando, como já dissemos, as proposições gramaticais apenas expressam nossas certezas mais profundas. Ao confundir proposições gramaticais com empíricas podemos, por exemplo, empreender investigações com a finalidade de verificar a correspondência do conteúdo de uma proposição gramatical com o mundo empírico. Tal investigação seria um contrassenso na medida em que propõe o confronto entre a experiência e em elemento linguístico que fundamenta a possibilidade da experiência. Esta imagem agostiniana da linguagem conduz à dificuldades filosóficas, ao tratar uniformemente proposições de naturezas diversas.

Moreno (1995) reflete sobre algumas imagens originadas a partir de más interpretações de expressões que utilizamos cotidianamente e apresentadas pelo próprio Wittgenstein nas Investigações Filosóficas. Destacaremos duas delas que, acreditamos, se aproximam mais do conteúdo que pretendemos abordar nesta dissertação. Segundo Moreno (1995):

As imagens surgem, segundo Wittgenstein, ao interpretarmos mal (missdeuten) nossas expressões cotidianas e ao tirarmos daí "as mais estranhas conclusões" (die seltsamsten Schlüsse). Tomemos primeiramente alguns exemplos fornecidos pelo próprio filósofo de expressões cotidianas e das respectivas interpretações que não nos causam problemas para indicar, em seguida, as interpretações que podem gerar imagens: 1. "A expressão algébrica determina todas as passagens numéricas"; [...] 4. "A máquina contém em si própria todos os seus movimentos possíveis" (MORENO, 1995, pg. 33).

Segundo Wittgenstein, estas expressões são comumente utilizadas em nosso cotidiano sem problemas. O filósofo oferece, inclusive, um exemplo de interpretação dessas expressões que são normais, que são possíveis e úteis nas atividades que empreendemos:

\footnotetext{
Vejamos o emprego normal dessas expressões, aquele em que a linguagem não gira no vazio. 1'. As pessoas que aprenderam a técnica de cálculo obtém, todas, os mesmos resultados, quando aplicam a fórmula algébrica em questão. [...] 4'. Os movimentos de uma máquina empírica dependem tanto da forma de construção quanto do material com o qual foi construída (MORENO, 1995, pg. 34).
}

No entanto, também são possíveis interpretações estranhas, interpretações que conduzam à dificuldades filosóficas. Tais interpretações desconsideram a prática com a linguagem, as ações com as quais o sentido de uma proposição está fundamentalmente relacionado e, assim, podem introduzir dificuldades filosóficas: 
Vejamos, agora, quais são as imagens que podemos construir - e que, de fato, construímos - a partir dessas mesmas expressões. 1*. A expressão algébrica é uma significação que antecipa a realidade: ela realiza todas as passagens de uma "maneira particular" (einer einzigarten Weiser) [...] 4*. A máquina ideal contém atualmente, de uma "maneira estranha" (in einer seltsamen Weise) todos os seus movimentos (MORENO, 1995, pg. $34)$.

As imagens, acima citadas, não são problemáticas em si visto que, possivelmente, podem possuir um uso legítimo em determinados contextos. O problema surge quando as imagens nos conduzem à formulação de questões problemáticas:

As imagens conduzem à interpretações que, ao invés de ser soluções, colocam dificuldades (Schwierigkeit). De fato, segundo Wittgenstein, com as imagens começam as dificuldades, pois quando procuramos determinar a maneira "peculiar", ou a "maneira estranha" com que as fórmulas algébricas realizam idealmente todas as passagens; [...] nestes casos chegamos a dificuldades sem solução: não conseguimos encontrar aquilo que colocamos como sendo a boa solução. Temos, somente, como diz Wittgenstein, "imagens que se cruzam", expressões linguísticas confusas - uma "super-expressão", um "superlativo filosófico" (MORENO, 1995, pg. 34).

Na medida em que nos acostumamos com determinada interpretação do conceito, levamos menos em conta os processos e técnicas empregadas na etapa preparatória do ensino das palavras e, portanto, seu caráter convencional. No lugar da multiplicidade das relações entre a palavra e os fragmentos empíricos do mundo convencionalizadas, surge a definição inequívoca do conceito e a força de sua necessidade como se estivesse respaldado no mundo empírico, ou seja, em como, por exemplo, os movimentos de uma máquina, "de fato" estariam presentes na máquina. Segundo Moreno (1995):

Chegamos, assim, a uma primeira característica das imagens. Por um lado, correspondem a "más interpretações", (missdeuten), interpretações estranhas de nossas expressões habituais. Por outro lado, e como consequência, conduzem a dificuldades sem solução. Wittgenstein reconhece, entretanto, outro aspecto das imagens que parece contrastar com o que acabamos de assinalar: as imagens conduzem a determinar o sentido (Sinn) de maneira inequívoca (eindeutig). As imagens nos "convidam" (fordern) a fazer uma aplicação determinada, elas contêm uma sugestão de aplicação, a saber um caso "normal" (normalen) de aplicação; as imagens, enfim, parecem "constringir" (zwingen) a uma aplicação determinada (MORENO, 1995, pg. 35).

Em outro exemplo analisado por Wittgenstein, o da leitura, podem surgir dificuldades para a identificação da tal atividade espiritual, consciente e particular à qual a leitura deveria corresponder. No entanto, muitas vezes isto não basta para que se desista de tal procura e atribui-se o insucesso à falta de ferramental científico-tecnológico para que se logre este objetivo. Afirma-se, então, que em momento futuro, quando a ciência neurológica 
estiver suficientemente desenvolvida, se identificará enfim tal atividade. Chamamos atenção para o fato de que a insistência nesse tipo de empreitada deve-se, sobretudo, à aplicação da imagem agostiniana de linguagem. Segundo Moreno (1995):

\begin{abstract}
Encontro, então, uma dificuldade insolúvel: não sou capaz de identificar uma tal atividade espiritual. Digo, então, que essa dificuldade é provisória, e remeto a solução para um momento futuro em que, por exemplo, o conhecimento do cérebro e do sistema nervoso será mais completo; nessa etapa futura, certamente, será possível indicar "a ligação de leitura" que deve existir; Por que esta solução provisória nos é satisfatória? Porque ao procurar "ver mais de perto" a verdadeira "ligação de leitura" estamos aplicando o próprio conceito de leitura segundo o modelo agostiniano. Em outros termos, afirmamos que é necessário, a priori, que a verdadeira leitura corresponda a uma ligação determinada, nervosa ou neuronal, para que seja possível distingui-la da falsa leitura, isto é, para que seja possível indicar a significação exata do conceito, o objeto a que a palavra substitui (MORENO, 1995, pg. 38).
\end{abstract}

Afirmamos, fundamentados em Moreno (1995) e Wittgenstein (2000), que as imagens apresentam dificuldades filosóficas no que diz respeito ao significado dos conceitos. No caso da leitura, qual seria a origem destas dificuldades? Da necessidade de compreender a leitura como necessariamente relacionada a um processo mental determinado? Moreno (1995) afirma que esta necessidade vem de nossa incapacidade de conceber como válidos os diferentes usos da palavra "leitura":

\begin{abstract}
A necessidade daquilo que podemos denominar "imagem agostiniana" vem de não admitirmos que a palavra "ler" possa ser aplicada de maneiras diferentes sem que, a cada aplicação, lhe corresponda uma referência determinada. A necessidade vem, da aplicação exclusivista do modelo referencial que, como no Tractatus, conduz a fazer "distinções sutis" entre as verdadeiras significações - isto é, os conceitos exatos - e as significações vagas - que é preciso descartar como sendo "inúteis" - e a crer na necessidade intrínseca dos conceitos exatos (MORENO, 1995, pg. $38)$.
\end{abstract}

A terapia filosófica, ou descrição gramatical, incide sobre a aplicação dogmática destas imagens. Sua finalidade é dissolver as confusões filosóficas causadas pela aplicação do modelo agostiniano por meio da exploração dos diversos usos que fazemos dos conceitos nos mais diversos contextos e destacando, assim, seu caráter multiforme e convencional. Desta forma, o leitor seria persuadido a reconhecer regras de aplicações dos conceitos diferentes daquelas previstas por determinadas imagens.

Wittgenstein relativiza a necessidade das imagens através da exibição dos diferentes usos que podemos fazer dos conceitos e chama a atenção para o caráter convencional da gramática dos conceitos. No entanto, apesar de considerar a gramática dos conceitos convencional, Wittgenstein afirma que tais convenções estão apoiadas em nossas formas de vida, ou seja, em nossos hábitos diante das palavras. Segundo Moreno (1995): 


\begin{abstract}
Wittgenstein se esforça por mostrar que a necessidade não é a expressão de essências extralinguísticas, como por exemplo, a forma lógica, do Tractatus; entidades mentais correspondendo à leitura, a compreensão, ao pensamento etc.; entidades ideais como a significação, os movimentos possíveis da máquina ideal, os objetos matemáticos etc.; essências ou entidades autônomas que se imporiam à nossa imaginação e ao nosso pensamento. A necessidade é, antes, o resultado de convenções a respeito dos usos das expressões linguísticas quando esses usos têm raízes profundas em nossas formas de vida - e quando, por razões circunstanciais e empíricas, não foram previstos usos para as expressões que lhes são contrárias (MORENO, 1995, pg. 36).
\end{abstract}

A terapia filosófica mostra, portanto, que a aplicação dos conceitos segundo a imagem agostiniana de linguagem não é a única possibilidade e que a escolha de uma determinada significação para um conceito trata-se de uma convenção podendo, assim, ser relativizada (MORENO, 1995). Engana-se, contudo, quem entender que o objetivo da terapia filosófica é o de reformular expressões para que não veiculem imagens. Segundo Moreno (1995):

Não se trata, todavia, de reformar expressões linguísticas, nem mesmo aquelas que veiculam imagens. A terapia não visa o aperfeiçoamento (Verbesserung) de expressões [...] Trata-se, apenas, de descrever a aplicação que é feita das imagens em cada caso. [...] evitando, assim a "dieta unilateral" de imagens exclusivistas (MORENO, 1995, pg. 39).

Podemos notar aqui, novamente, a importância que mostrar possui para o filósofo. O método da descrição gramatical consiste em mostrar os diversos usos que realizamos dos conceitos, para que o interlocutor seja persuadido de que existem outras significações possíveis, na medida em que é capaz de ver que as diversas aplicações dos conceitos possuem sua utilidade em nossa forma de vida. Não há um princípio externo que possa servir de fundamento para a correção, ou aperfeiçoamento, destas expressões.

Wittgenstein não tem a intenção de abolir as imagens, mas, apenas, relativizar a força da necessidade que apresentam e evitar, assim, as confusões filosóficas oriundas delas:

As imagens são interpretações habituais, ou "normais" da significação: é aquilo que dizemos ao nos interrogarem, é aquilo que diz o matemático a respeito dos fatos da Matemática etc. Mesmo sendo importantes para a nossa vida, essas interpretações não devem ser privilegiadas: não se deve atribuir a elas o estatuto de "pré-juízo" (Vorurteil) ao qual a realidade deva corresponder (MORENO, 1995, pg. 41).

Wittgenstein aponta para duas fontes dos enganos filosóficos: para uniformidade aparente das palavras e pela crença de que inovando nossa terminologia estamos descobrindo novos fatos. Segundo Moreno (1995): 


\begin{abstract}
Wittgenstein aponta para duas fontes de onde podem nascer os enganos filosóficos. A primeira consiste em deixar-se "enfeitiçar" pela linguagem, pela sua forma aparentemente uniforme - como aquela das ferramentas em uma caixa - que encobre a gramática do uso das palavras. [...] A segunda fonte de enganos para o filósofo, assim como nas outras situações em que a linguagem é colocada em férias, está ligada à decisão que tomamos em utilizar uma nova forma de expressão linguística, aquela forma que nos parece ser a mais conveniente para ressaltar a nuance desejada, que acreditamos ter descoberto ao pensarmos a respeito da significação. O engano surge no momento em que passamos acreditar, graças à inovação terminológica, que estamos fazendo afirmações sobre fatos novos que descobrimos, à maneira do que faz, legitimamente, o cientista (MORENO, 1995, pg. 80).
\end{abstract}

A primeira fonte de enganos filosóficos apontada por Wittgenstein é a uniformidade aparente das palavras. Wittgenstein comenta que considerando apenas a aparências das palavras, podemos concluir erroneamente que possuem a mesma função. No entanto, a partir de uma analogia entre a linguagem e uma caixa de ferramentas, o filósofo nos instiga a ver a multiplicidade da linguagem. Segundo Wittgenstein (2000):

Pense nas ferramentas em sua caixa apropriada: lá estão um martelo, uma tenaz, uma serra, uma chave de fenda, um metro, um vidro de cola, cola, pregos e parafusos. - Assim como são diferentes as funções desses objetos, assim são diferentes as funções das palavras. (E há semelhanças aqui e ali.) Com efeito, o que nos confunde é a uniformidade da aparência das palavras, quando estas nos são ditas, ou quando com elas nos defrontamos na escrita e na imprensa. Pois seu emprego não nos é tão claro. E especialmente não o é quando filosofamos! (WITTGENSTEIN, 2000, § 11).

A segunda fonte de enganos filosóficos trás novamente à tona a preocupação de Wittgenstein com o fato de que os filósofos apresentam a tendência de tratar dos problemas filosóficos da mesma forma com que se tratavam os problemas científicos, isto é, a partir da investigação e descoberta de fatos aos quais as proposições devessem corresponder. Para Wittgenstein, no entanto, isso não era o propósito da filosofia, mas, antes, a expressão da extrapolação dos paradigmas de produção do conhecimento das ciências para as demais áreas do conhecimento, uma espécie de dogmatismo, o cientificismo. Para Wittgenstein, "os problemas de caráter filosófico podem ser apenas dissolvidos pela descrição clara de sua natureza linguística" e não pela explicação de processos causais entre entidades do mundo empírico (MORENO, 1995).

O filósofo das Investigações afirma que, no exercício de sua atividade, os filósofos estão mais propensos a enveredarem por interpretações estranhas que levem ao surgimento de confusões filosóficas insolúveis. Esta maior tendência dos filósofos em cair em confusões se deveria ao fato de que, ao filosofar, os mesmos colocariam a linguagem em férias, isto é, tratariam dos conceitos e palavras habituais fora de seus contextos efetivos de uso e, portanto, desconsiderando suas funções em nossas formas de vida para, no lugar, questionar 
livremente, no vazio, sobre seu verdadeiro significado, sua significação exata (MORENO, 1995).

Recapitulando o que dissemos nesta seção, as imagens são interpretações que fazemos de nossas expressões habituais e que surgem no complexo processo de uso dos conceitos. Tais interpretações são importantes para nossas formas de vida porque propõem formas de organização da experiência e permitem que se destaquem certas nuances dos conceitos que compartilhamos. No entanto, as imagens podem contribuir com o surgimento de confusões filosóficas quando nos esquecemos das convenções que realizamos na medida em que fizemos usos dos conceitos. Assim podemos, por exemplo, passar a acreditar que a determinada imagem do conceito correspondam objetos e fatos do mundo empírico, ao tratar de proposições gramaticais, de caráter convencional, como proposições empíricas, descritivas do mundo.

O objetivo da terapia filosófica é proporcionar a contemplação da multiplicidade dos usos previstos para os conceitos pela gramática ensinada através das técnicas da linguagem durante a etapa preparatória, dos jogos primários, para que, assim, se relativize a força das imagens, seu poder de orientar nosso pensamento em uma determinada direção como se esta fosse necessária, a única concebível.

\subsection{Wittgenstein e o ensino}

Passaremos agora a apresentar algumas implicações da concepção de linguagem presente nas Investigações Filosóficas para o ensino.

A partir da concepção de linguagem do segundo Wittgenstein e da epistemologia do uso de Moreno, podemos afirmar que uma das tarefas do ensino consiste em introduzir os alunos nos jogos de linguagem próprios de cada disciplina. Dessa forma, ensinar ciências consistiria em tornar o aluno capaz de participar da instituição que é a disciplina escolar de ciências, física, biologia, química, etc.

A introdução dos alunos na dinâmica de funcionamento das disciplinas escolares não diz respeito apenas a um conjunto de verdades que estes alunos devam saber enunciar, mas, sobretudo, a um certo modo de operar com a linguagem na medida em que desempenham tarefas específicas destas disciplinas. O ensino não se reduz a um saber quê, mas, antes, inclui um saber fazer. Segundo Ryle $(2010)^{2}$

Esqueçamos por um instante a memorização de verdades e, evidentemente, a de rimas e canções, e centremos nossa atenção na aquisição de capacidades, estratégias e de soluções eficientes. Pensemos, por exemplo, em lições de desenhos, de aritmética, de críquete e, se quiserem,

2 Segundo (MONK, 1995), Gilbert Ryle e Ludwig Wittgenstein mantiveram uma relação de amizade durante alguns anos, o que nos permite concluir que a filosofia de Wittgenstein tenha exercido alguma influência nas reflexões sobre educação de Ryle. 
mesmo de filosofia. Elas não podem consistir, exclusivamente, no ditado de proposições, e nem sequer conter um número demasiadamente elevado delas. Por mais proposições verdadeiras que a criança tenha aprendido de memória, começará a desenhar ou a jogar críquete quando tiver um lápis na mão, ou um taco de críquete, e tiver praticado alguns movimentos com eles; e, mesmo quando realize notáveis progressos nesses terrenos, pouco ou nada poderá responder a seus pais se à tarde lhe pedirem que lhes recite as proposições que aprendeu (RYLE, 2010, pg. 76). ${ }^{3}$

No trecho acima, fica destacado o papel das práticas que constituem uma disciplina escolar. No entanto, isso não quer dizer que as palavras, conceitos e proposições verdadeiras não tenham um papel importante no ensino, mas, antes, que o sentido destes últimos está fortemente relacionado com as práticas no interior dos jogos de linguagem da disciplina em questão. Assim como Ryle, utilizaremos o termo treinar para fazer referência a ideia de ensinar a fazer algo:

Para evitar a ambiguidade entre "ensinar que" e "ensinar a fazer algo", introduzirei a palavra "treinar". O professor de desenho, de linguagem ou críquete, treina seus alunos no desenho, na pronúncia francesa ou em certo jogo esportivo, e este treinamento inclui apenas algumas informações verbais passíveis de serem repetidas oralmente. O mesmo vale para a filosofia (RYLE, 2010, pg. 76).

Parte do treinamento consiste na execução, por parte do aluno, de exercícios estereotipados. Através da prática repetitiva dos exercícios, os alunos adquirem domínio sobre os mesmos (RYLE, 2010). Contudo, o exercício consiste - como dissemos - em apenas uma parte do treinamento. Espera-se que os alunos avancem para além da mera repetição de exercícios, que apliquem a destreza adquirida em tarefas superiores. Segundo Ryle (2010):

\begin{abstract}
Uma vez capacitado a fazer certas coisas elementares automaticamente, sem pensar nelas, espera-se que o aluno avance para além deste ponto e possa empregar o automatismo que lhe fora inculcado na execução de tarefas superiores, não automáticas, que não podem ser realizadas sem pensar (RYLE, 2010, pg. 76).
\end{abstract}

O domínio destas técnicas, destes exercícios, permitirá ao aluno participar ativamente de uma comunidade de prática, possibilitará que o aluno utilize as técnicas empregadas na execução dos exercícios em contextos diversos dos originais. O sentido de uma proposição relevante para determinada disciplina escolar está fundamentado nas atividades próprias desta disciplina, no modus operandi desta comunidade e, por isso, a compreensão de uma proposição depende da capacidade do aluno em fazer parte da instituição em que esta é empregada:

3 As citações de Gilbert Ryle e John Passmore foram extraídas de uma tradução feita por Helena Meidani, que participava do grupo de estudos coordenado por José Mario Pires Azanha no final da década de 90, e revisada por alguns membros do mesmo grupo. 
... mesmo aprender que uma proposição é verdadeira é ter aprendido $a$ fazer outras coisas além de repetir as palavras com as quais fora ditada a verdade. Mesmo aprender um simples fato geográfico, é familiarizar-se com algumas tarefas geográficas não habituais, por mais elementares que sejam (RYLE, 2010, pg. 78).

Saber que, por exemplo, a capital da Espanha é Madri exige que se conheça a divisão política do território mundial, que Madri é um território contido no território espanhol e que, portanto, não pode se encontrar dentro de nenhum outro território nacional, que está separado de São Paulo pelo oceano e que está relativamente próximo de Lisboa. Ou seja, saber que Madri é capital da Espanha pressupõem um complexa prática com a linguagem que se fundamenta, inclusive, em ações como consultar um mapa, compreender as informações de um mapa pela leitura de seus elementos simbólicos, operar com a escala de distâncias, etc. Sobre o ensino dos diferentes métodos de cada disciplina Ryle (2010) reflete:

\begin{abstract}
Como se ensina métodos ou maneiras de fazer uma coisa? Não há respostas simples para esta questão. As diferentes artes e ofícios valem-se de distintas classes de disciplinas: e mesmo em um campo particular, o do desenho por exemplo, existem diferenças entre as maneiras de trabalhar de um ou outro professor. [...] Mas uma coisa é indispensável: o aluno deve, sob pressão ou a partir de seu próprio interesse, ambição ou consciência, praticar a execução do que está aprendendo a fazer. [...] Os métodos de operação que lhe foram ensinados convertem-se em seus próprios métodos pessoais de operar, através de sua própria prática, criticada e auto-criticada. Quer se trate da escrita ou da gramática latina, de esporte, aritmética ou filosofia, aprende a conhecer os caminhos, não tanto por vê-los ou ouvir coisas sobre eles, mas sim por suas tentativas de caminhar por eles, de andar hoje com menor torpor, lentidão e risco do que ontem (RYLE, 2010, pg. 82).
\end{abstract}

No trecho acima, Ryle afirma que as diferentes artes e ofícios apresentam diferentes classes de disciplinas, isto é, diferentes conjuntos de atividades, formas de proceder, que as constituem. Esta afirmação chama nossa atenção para o fato de que diferentes disciplinas escolares exigem a iniciação dos alunos em diferentes atividades, diferentes tradições de como operar com a linguagem e o mundo material. Assim, as convenções que sustentam as diversas atividades, suas gramáticas, também são diferentes entre si.

Os alunos tornam-se capazes de participar das disciplinas escolares na medida em que assimilam a maneira de agir no interior dos jogos de linguagem que lhes são característicos. O processo de assimilação da gramática de uma disciplina inclui a prática dos exercícios por parte dos alunos, a docilidade ao ser corrigido pelo professor ou por um participante da comunidade mais habituado à suas regras e, ainda, a capacidade dos alunos se auto-guiarem na busca por melhorarem suas habilidades na execução dos exercícios propostos. 
O domínio de diferentes técnicas empregadas nas mais diversas disciplinas escolares possibilita a experiência de fenômenos e o reconhecimento de objetos próprios destas disciplinas. No caso das ciências, por exemplo, apenas os estudantes que entram em contato com a teoria cinética da temperatura, que aceitam suas convenções e pressupostos, são capazes de observar o fenômeno de aumento da temperatura indicada por um termômetro de mercúrio como efeito do aumento de agitação das moléculas do elemento e sua consequente expansão volumétrica. Sobre o papel do domínio de técnicas para a possibilidade da experiência Moreno (1995) diz:

Como diz Wittgenstein, o substrato de nossas vivências, intuições e conceitos é o domínio (Beherrschen) de uma técnica. Glosando Kant, podemos dizer que, de um ponto de vista wittgensteiniano, o princípio supremo das proposições gramaticais sintéticas é que todo objeto esteja submetido às condições gramaticais de uso das palavras, que se exprimem em uma experiência linguística convencional. Os domínios de diferentes técnicas e atitudes são as condições de possibilidade da experiência em geral e, ao mesmo tempo são as condições de possibilidade dos objetos da experiência (MORENO, 1995, pg. 104).

Por um lado, o domínio de diferentes técnicas convencionais é que permite a experiência na medida em que possibilita que fragmentos do mundo empírico sejam inseridos no interior da linguagem e, portanto, possibilitam uma forma de perceber e agir com sentido no mundo. Por outro lado, o sentido dos próprios objetos da experiência emergem de uma gramática, ou seja, da maneira que convencionamos organizar nossa experiência através de conceitos, proposições gramaticais etc.

As proposições gramaticais "são normas que estabelecemos enquanto condições para a construção de práticas descritivas de fatos: são a etapa preparatória para a aplicação dos conceitos científicos" (MORENO, 1995). As proposições gramaticais, nossas convenções a respeito das regras de aplicação dos conceitos é que permitem o uso descritivo da linguagem e não, como pensava o filósofo do Tractatus, um isomorfismo entre mundo e linguagem ou entre conceito e objeto empírico. Sobre os conceitos Moreno (1995) diz :

... são, para Wittgenstein, formas convencionais de organizar a experiência, quadros de referência que estabelecemos para comparar os objetos. Os conceitos devem responder a finalidades suficientemente bem distintas e fixadas para que possam ser erigidos em instituições e fazer parte de formas de vida. A necessidade surge quando os conceitos são inseridos em proposições gramaticais - e a necessidade é, nesse caso, constitutiva dos fatos (MORENO, 1995, pg. 113).

Na medida em que os alunos são inseridos nas dinâmicas das disciplinas de ciências, ou seja, na medida em que compreendem as formas de agir, da própria disciplina, segundo um conjunto de regras linguísticas de caráter convencional, os alunos se tornam capazes de observar certos fenômenos a partir de conceitos, leis e objetos semelhantes aos de seus 
professores de ciências. Começam a agir, a partir de um conjunto comum de convenções, no interior dos jogos de linguagem próprios das ciências ou, ao menos, próprios das ciências escolares com relativa autonomia, aplicando os conceitos e procedimentos aprendidos em novos contextos de aplicação, contextos estes nunca apresentados antes pelo professor.

$\mathrm{Na}$ atividade científica, as diferentes aplicações de conceitos e procedimentos, por parte dos membros da comunidade, em novos contextos estão sujeitas à aprovação dos demais membros, assim como as novas aplicações dos alunos têm suas legitimidades avaliadas pelo professor da disciplina. Assim, um conceito - minimamente aprendido pelos alunos - sofre mudanças, refinamentos, na medida em que é empregado em novos contextos. Inicialmente, as aplicações que os alunos fazem dos conceitos precisam ser corrigidas ou confirmadas para que seja garantido o processo de incorporação da gramática de um conceito científico aceito. No entanto, uma vez que os alunos dominem a gramática dos conceitos em algum grau, pode-se admitir que os mesmos sejam capazes de avaliar criticamente a aplicação dos mesmos, isto é, são capazes de refletir sobre a própria gramática dos conceitos.

Para se desenvolver um espírito crítico, isto é, para ser capaz de avaliar a conveniência de certas convenções linguísticas que aceitamos ao longo do processo de educação, é necessário que sejamos capazes de participar das principais instituições humanas. É necessário que tenhamos compreendido suas gramáticas. Segundo Passmore $(2010)^{4}$ :

\begin{abstract}
Para ser culto deve-se estar apto a participar do pensamento criativo das grandes tradições humanas - ciência, história, literatura, filosofia, tecnologia - e, para participar dessas tradições, deve-se primeiro ser instruído, aprender uma disciplina e, empregando a linguagem de Richard Peters, ser "iniciado". O espírito crítico que o professor se interessa em desenvolver significa a capacidade de ser participante crítico de uma tradição, mesmo se o efeito de tal crítica for a modificação profunda dos modi operandi dessa tradição (PASSMORE, 2010, pg. 141).
\end{abstract}

Se considerarmos as grandes tradições humanas como constituídas por jogos de linguagem, então podemos afirmar que apenas se desenvolve espírito crítico na medida em que se domina uma variedade de gramáticas relacionadas às principais tradições humanas. Os alunos devem conhecer suficientemente as regras subjacentes aos diversos domínios da sociedade para que, a partir destas regras, avaliem suas limitações, proponham mudanças, abandonem-nas, etc. Ignorar estas gramáticas ou assimilar completamente apenas uma dentre as diversas possíveis inviabiliza o desenvolvimento do espírito crítico. Segundo Passmore (2010):

O problema pedagógico que o professor que se dispõe a ensinar seus alunos a serem críticos enfrenta é muito similar ao que ele tem quando se

4 As citações de Gilbert Ryle e John Passmore foram extraídas de uma tradução feita por Helena Meidani, que participava do grupo de estudos coordenado por José Mario Pires Azanha no final da década de 90, e revisada por alguns membros do mesmo grupo. 


\begin{abstract}
prepara para cultivar-lhes a imaginação. Inevitavelmente, a instrução tem um papel importante em nossos sistemas escolares. De nenhuma outra maneira podemos ajudar nossos estudantes a participarem das grandes tradições. Eles têm que aprender uma variedade de regras. Têm que se pôr em dia com os conhecimentos que já tenham adquirido. Só desta maneira chegarão a uma posição na qual poderão criticar de maneira fecunda, de forma a sugerir alternativas (PASSMORE, 2010, pg. 143).
\end{abstract}

As Imagens de alguns conceitos veiculadas nas comunidades científicas e / ou entre os professores de ciências podem constituir obstáculos à capacidade do aluno agir diante de determinadas situações. Uma definição conceitual que privilegie um aspecto do conceito em detrimentos dos demais pode comprometer a capacidade dos alunos de experimentarem certos fenômenos, de reconhecerem certos objetos, de desenvolverem o espírito crítico em determinadas áreas e de resolverem certos problemas.

\title{
2.6 Síntese do capítulo e consequências para este trabalho
}

Na medida em que tentamos sintetizar o conteúdo deste capítulo apresentamos, a seguir, alguns resultados apresentados por Wittgenstein, Moreno, Ryle e Passmore em itálico - e, em seguida, um conjunto de consequências para o desenvolvimento deste trabalho.

I) A ligação entre linguagem e mundo não é direta, imediata, mas mediada por técnicas convencionais de ligação entre objetos do mundo e palavras (MORENO, 1995): O sentido dos conceitos científicos no contexto escolar, como é o caso do conceito de energia, é estabelecido mediante as técnicas empregadas em seu ensino. Assim, sua gramática é constituída na medida em que outras palavras, objetos empíricos, fenômenos, etc forem associados à palavra energia.

II) O uso da linguagem em contextos diversos, por exemplo para descrever um fenômeno observado, só é possível a partir do estabelecimento de um conjunto de regras de aplicação das palavras constituído na etapa preparatória da linguagem (MORENO, 1995): A gramática do conceito de energia, resultado da atividade de ensino, é condição de possibilidade para seu uso em diferentes contextos e com diferentes finalidades. Por exemplo, a associação da palavra energia com objetos à certa altura na superfície terrestre e com corpos em movimento, juntamente com outras lições, possibilitará que os alunos compreendam e avaliem o funcionamento de uma usina hidroelétrica.

III) O sentido das palavras é seu uso efetivo no interior dos jogos de linguagem e, portanto, as palavras estão fortemente relacionadas com as práticas que, habitualmente, as acompanham (MORENO, 1995): O conceito de energia e o princípio de conservação da energia estão historicamente relacionados com os problemas enfrentados pela comunidade de 
engenheiros e cientistas interessados no aprimoramento de motores a vapor ${ }^{5}$ e, atualmente, com problemas enfrentados por cientistas e engenheiros nos mais diversos contextos.

IV) Os conceitos orientam a ação e possibilitam as experiências mas, também, têm suas gramáticas afetadas pelo uso e pela experiência (MORENO, 1995): Na medida em que se aplica a conservação da energia mecânica na resolução de problemas passa-se a ver o conceito de energia como uma quantidade que se conserva enquanto os fenômenos ocorrem. Além disso, se em uma atividade de laboratório nossas expectativas acerca de um fenômeno são confrontadas, pode ser que passemos a considerar novos aspectos do conceito de energia como, por exemplo, quando não verificamos a conservação da energia mecânica em experimentos onde ela é esperada, podemos investigar possíveis "perdas" de energia por atrito.

V) Podem surgir imagens relacionadas a conceitos na medida em que se faz uso da linguagem. As imagens são interpretações estranhas que fazemos de nossas expressões habituais. Os problemas filosóficos que surgem com as imagens devem-se, principalmente, à confusão entre proposições gramaticais e proposições empíricas (MORENO, 1995): Na medida em que repetidamente se afirma, por exemplo, que um corpo com velocidade "possui" energia, poderíamos levar os estudantes a pensarem que a energia fica armazenada de alguma maneira dentro dos corpos, ou seja, que a energia corresponda a um ente que se localiza em alguma parte de um corpo.

VI) A força sugestiva das imagens pode nos conduzir a concepções dogmáticas na medida em que adotamos, consciente ou inconscientemente, as interpretações à elas associadas como as verdadeiras interpretações recusando, assim, as demais interpretações e aplicações dos conceitos (MORENO, 1995): Em consequência do que foi dito no item anterior, caso fizéssemos um uso exclusivista de uma imagem do conceito de energia, expressa pela proposição apenas os corpos possuem energia seríamos incapazes de conceber que entes sem corpos (como por exemplo o fóton que tem massa nula), sem um onde para a energia ficar, possam estar associados ao conceito de energia. Essa imagem do conceito é fruto da aplicação da imagem agostiniana da linguagem onde para cada palavra deve haver um ente correspondente. No caso da energia, este ente estaria presente no interior dos corpos materiais.

VII) O objetivo da filosofia wittgensteiniana é livrar o pensamento das confusões causadas por imagens dogmaticamente aplicadas pelos filósofos através da exploração dos diversos usos de um conceito e permitindo, assim, que se vislumbre novas possibilidades de sentido e obtendo como resultado a relativização do sentido sugerido pelas imagens (MORENO, 1995): No escopo deste trabalho, nos preocupamos com as visões dogmáticas

5 Certamente há registros de contribuições notáveis de cientistas de diferentes contextos como, por exemplo, Julius Robert Mayer (1814-1878), que enunciou o princípio de conservação da energia a partir da observação das diferenças de tonalidade apresentadas pelo sangue de seus pacientes que habitavam regiões com diferentes características climáticas. 
oriundas das imagens associadas ao conceito de energia na medida em que estas constituam obstáculos para a compreensão, avaliação e resolução de problemas e situações que os estudantes devem ser capazes de compreender, avaliar e resolver. A dissolução destas imagens dogmáticas do conceito de energia passa por mostrar que os diversos usos do conceito possuem semelhanças de família entre si, negando, assim, a possibilidade de se extrair uma definição essencial capaz de fazer justiça a todos os usos do conceito.

VIII) Ensinar uma disciplina aos estudantes inclui proporcionar condições para que os mesmos dominem um conjunto mínimo de regras de aplicação da linguagem em contextos específicos. O domínio da gramática dos conceitos ocorre na medida em que os estudantes são introduzidos nos jogos de linguagem próprios da disciplina em questão e, portanto, na medida em que agem dentro de uma comunidade (RYLE, 2010): Ensinar física aos estudantes inclui treinar os alunos no uso dos principais termos, equações, conceitos, princípios, procedimentos e critérios de avaliação da física. Este treinamento ocorrerá em um determinado contexto, dentro de uma determinada temática geral, com a finalidade de atingir determinados objetivos. Assim, um determinado conceito, como o de energia, terá sua gramática constituída através de diversas situações escolares da disciplina de física, de outras disciplinas escolares e também da maneira como empregamos o conceito de energia no cotidiano.

IX) O ensino pressupõe que os estudantes sejam capazes de, a partir da gramática dos conceitos aprendida, aplicarem conceitos e técnicas à situações diversas, situações semelhantes, mas nunca apresentadas antes pelo professor (RYLE, 2010): Um critério para decidir se um estudante aprendeu o conceito de energia na educação básica poderia, por exemplo, ser a capacidade do estudante em fazer uso do conceito para a análise, avaliação e solução de situações e problemas suficientemente diversos entre si. Espera-se que, em alguma medida, o estudante avance para além das lições propostas pelo professor e obtenha sucesso na resolução de problemas físicos que envolvam diferentes arranjos de corpos e interações de diferentes naturezas.

X) A capacidade de pensamento crítico somente pode ser exercida por indivíduos iniciados em diversas tradições humanas, por indivíduos que dominem uma diversidade suficiente de gramáticas para que, a partir de diferentes pontos de partida, se possa avaliar a conveniência das diferentes convenções que, socialmente, aceitamos e seguimos (PASSMORE, 2010): Para que um estudante seja capaz de avaliar criticamente, por exemplo, as matrizes energéticas de cada uma das nações, a eficiência das diferentes máquinas comercializadas ou a conveniência de uma instalação doméstica de placas fotovoltaicas, os estudantes precisam dominar as gramáticas de diversas disciplinas como, para citar algumas delas, da física, da ecologia, da matemática, da economia e da política.

Uma das características do conceito de energia que argumenta em favor da importância de seu ensino é que se trata de um conceito capaz de articular os diferentes 
ramos da física entre si, os diferentes ramos das ciências e, ainda, os ramos das ciências com os setores econômicos, sociais e tecnológicos. Por isso, acreditamos que o conceito de energia seja fundamental para a avaliação e o pensamento crítico de questões emergentes na sociedade contemporânea como a crise energética, as disputas políticas pelo controle de combustíveis fósseis, a produção de máquinas mais eficientes e menos poluentes, etc. 



\section{Reflexões sobre ciência, método e o con- ceito de energia}

Em face das consequências extraídas das concepções de linguagem e filosofia do segundo Wittgenstein, acreditamos que seja pertinente para este trabalho apresentar algumas características da ciência por ser, a ciência, uma tradição humana cujas práticas conferem sentido ao conceito de energia ${ }^{1}$.

Para isso, optamos por apresentar uma certa visão hegemônica de ciência em contraponto com algumas críticas formuladas, principalmente, por Kuhn e Feyerabend. Por fim, apresentamos um critério de demarcação da atividade científica proposto por Popper.

Ainda neste capítulo, apresentamos algumas características do conceito de energia na ciência e no ensino de ciências. Na ciência, exploramos a relação do conceito com a busca por processos de conversão de "poderes" de determinadas naturezas em outras e com a comunidade de engenheiros interessados por máquinas térmicas. No ensino de ciências, exploramos os problemas e insuficiências mais relatadas pelas pesquisas publicadas ao longo das últimas décadas.

\subsection{Uma concepção de ciência e método}

Received view é um termo cunhado por Putnam para designar uma concepção acerca da ciência e de sua metodologia relacionada intimamente com o neopositivismo e que apresentava características do baconismo e do cartesianismo. Uma de suas principais teses era a de que a ciência produzia conhecimento através da aplicação de um método especial, racional e, além disso, que $a$ racionalidade era o fundamento do conhecimento científico. Esta visão de ciência se proliferou entre o público leigo letrado (AZANHA, 2011).

Segundo esta visão de ciência, o método científico estaria associado a existência de um conjunto específico de regras e, sendo assim, seria possível classificar uma atividade como científica ou não a partir da identificação de certos elementos e características próprias do método científico. A separação, feita por Reichenbach, da ciência em contexto de descoberta e contexto de justificação permitia supor certa estabilidade do empreendimento científico

1 Poderíamos dizer que o conceito de energia pode ser usado em diversos contextos como, por exemplo, no cotidiano, em discursos místicos, em propagandas de alimentos, etc. No entanto, estamos interessados em discutir a gramática do conceito científico de energia, mais especificamente do conceito físico de energia. 
e, portanto, fortalecia a crença em um método capaz de produzir conhecimento confiável (AZANHA, 2011). Em outras palavras, acreditava-se que fatores históricos, sociais e políticos - por exemplo - não abalavam e nem modificavam os fundamentos da ciência.

De um lado, o estudo do "contexto de descoberta" da ciência estaria relacionado com a compreensão dos fatores extracientíficos que condicionavam a produção do conhecimento e caberia, por exemplo, à história, sociologia e psicologia. Do outro, o estudo do "contexto de justificação" visaria fazer a reconstrução racional da ciência e sua crítica de forma a, digamos, isolar a racionalidade científica das questões de "outras esferas" como, por exemplo, disputas políticas entre grupos e nações.

Segundo Azanha (2011, pg. 169), "Essa reconstrução visaria à descrição da estrutura lógica do conhecimento e teria como complemento uma 'tarefa crítica' cujo objetivo seria o exame das condições de validação do conhecimento científico e do seu nível de precisão". Para Reichenbach, apenas o estudo da ciência em seu "contexto de justificação" teria valor epistemológico.

A received view defendia que a ciência é uma atividade uniforme, ou seja, que existe apenas uma prática científica e que exista um conjunto de regras comum às diversas ciências da natureza; que exista uma única racionalidade a partir da qual a validade dos conhecimentos científicos são julgados e, consequentemente, que esta racionalidade é o fundamento último da ciência. Além disso, defende que a produção do conhecimento científico é cumulativa e, portanto, que o progresso é próprio da ciência.

A concepção de ciência que adotaremos neste trabalho se diferencia substancialmente da concepção proposta anteriormente. Em primeiro lugar, não há um método científico no sentido de que possamos enumerar um conjunto de características do fazer científico que seja comum à todas as ciências naturais, mas, antes, a prática científica é complexa e não redutível a um conjunto de regras. Assim, compreendemos a prática científica efetiva como o próprio fundamento do conhecimento científico (AZANHA, 2011). Segundo Laudan (2000):

\footnotetext{
Por "método científico" entendo simplesmente as técnicas e procedimentos que um cientista usa ao realizar experimentos e construir teorias. Por "teorias do método científico" entendo as opiniões metacientíficas explícitas que um cientista adota ao examinar a lógica da inferência científica. A história do método científico é na realidade a história de uma arte ou técnica largamente intuitiva, que tem muito pouco a ver, provavelmente, com o discernimento metacientífico.(LAUDAN, 2000 apud AZANHA, 2011, pg. 139)
}

Notamos o esforço de Laudan no sentido de diferenciar as escolhas metodológicas que efetivamente ocorrem, ou ocorreram, na prática científica da posterior organização dessas escolhas realizadas por um cientista ou filósofo que tem como finalidade analisar a lógica da inferência científica. Thomas Kuhn também formula algo semelhante com relação 
à possibilidade de descrição da prática científica a partir de um conjunto de regras, de um paradigma. Segundo Kuhn (2017):

A ciência normal é uma atividade altamente determinada, mas não precisa ser inteiramente determinada por regras. É por isso que, no início deste ensaio, introduzi a noção de paradigmas compartilhados, em vez das noções de regras, pressupostos e pontos de vistas compartilhados como sendo a fonte de coerência para as tradições da pesquisa normal (KUHN, 2017, pg. 113).

Nos deparamos, novamente, com o deslocamento do fundamento do conhecimento científico de um suposto conjunto de regras para a prática efetiva da investigação científica. Kuhn introduz a noção de paradigma $a^{2}$ como um certo conjunto de práticas tacitamente estabelecidas que condiciona a possibilidade de produção do conhecimento científico, inclusive o próprio reconhecimento de certas questões como científicas. Neste mesmo sentido, Azanha (2011) argumenta que ser cientista não é apenas apreender um sistema conceitual e depois aplicá-lo à práticas de investigação:

... mas também adquirir hábitos, habilidades, valores etc., e ter suas investigações e os problemas que as motivaram reconhecidos como científicos pelos padrões de análise e de avaliação aceitos pela corporação científica: e, como já dissemos, nem sempre essa aceitação ocorre com relação a um código explicitamente formulado mas sim com relação a pontos tacitamente articulados (AZANHA, 2011, pg. 144).

Para ilustrar a importância da prática na ciência, Kuhn (2017) reflete sobre o processo de formação dos cientistas dizendo que estes não aprendem teorias, conceitos e leis de maneira isolada da prática, mas, antes, são apresentadas aplicações destas teorias, conceitos e leis desde o início, e acrescenta que "o processo de aprendizado de uma teoria depende do estudo das aplicações, incluindo-se aí a prática na resolução de problemas, seja com lápis e papel, seja com instrumentos num laboratório" (KUHN, 2017, pg. 120). Quer dizer, aspectos abstratos e práticos estão entrelaçados desde o início do processo de formação do cientista. Segundo Kuhn (2017):

Ao aprender um paradigma, o cientista adquire ao mesmo tempo uma teoria, métodos e padrões científicos, que usualmente compõem uma mistura inexplicável. Por isso, quando os paradigmas mudam, ocorrem alterações significativas nos critérios que determinam a legitimidade tantos dos problemas como das soluções propostas (KUHN, 2017, pg. 198).

Feyerabend (2011) também dá sinais da importância da ciência como prática e se opõe a uma visão de ciência como atividade completamente regrada destacando a

2 Wittgenstein chama de paradigma os modelos que são incorporados à linguagem com função normativa, como objetos de comparação, que servem como meio de apresentação dos conceitos (WITTGENSTEIN, 2000, § 50). 
semelhança entre o trabalho do experimentador laboratorial e dos artistas. Além disso, reflete sobre o fato de que os resultados almejados pela comunidade científica precisam atender a certos critérios extracientíficos como a simplicidade e o senso estético:

Nas ciências, temos não apenas enunciados (a velha ideia de que a ciência
é um sistema de enunciados foi, entrementes, completamente desacre-
ditada), mas observações, equipamento experimental, relação intuitiva
entre observadores e seu equipamento, a qual tem de ser aprendida de
maneira prática e não por meio de anotações, o trabalho dos experimen-
tadores, que tem muito em comum com o trabalho dos artistas - o que
eles querem não são meramente resultados, mas resultados que emergem
de um mundo simples, convincente e esteticamente agradável - e assim
por diante (FEYERABEND, 2011, pg. 269).

Azanha (2011) também apresenta uma concepção de ciência como prática, ao enfatizar que diversos elementos dessa prática podem ser tácitos, ou seja, não são passíveis de explicitação ou explicação por meio de enunciados e que há íntima relação entre conhecer estas práticas e ter sido introduzido nelas:

Aprender uma prática envolve habilidades, imitação e exercícios e não apenas a aquisição da formulação linguística de um código que, aliás, pode nem estar explicitado nem ser explicável por uma enunciação. [...] A prática é um saber fazer e não um saber que aplicado a ela. Não há duas coisas: o saber de um lado e depois a prática à qual o saber se aplica. Há apenas o saber fazer que é a prática. Uma prática ineficaz pode transformar-se numa prática eficaz pela correção de erros, mas somente "a prática do uso da regra mostra o que é um erro na sua aplicação". Exemplo: "aprendemos a natureza do cálculo ao aprender a calcular", não antes. Seria impossível corrigir os erros antes (AZANHA, 2011, pg. 182).

Aqui notamos o caráter fundamental dos hábitos de uma comunidade, de sua prática, para a formação de aprendizes que têm a intenção de tornarem-se parte dela. No exemplo do cálculo fornecido por Azanha, fica claro que o fundamento último do cálculo é a maneira como uma determinada comunidade opera ao calcular, sua prática do cálculo, e que somente com relação a esta forma de operar é que um aprendiz poderá ser corrigido até assimilar as formas corretas de agir. Podemos inclusive afirmar que toda teoria que pretenda explicitar e explicar a natureza do cálculo não o fundamenta, apesar de parecer que sim, mas antes, tem seu fundamento na própria prática e nas convenções explícitas ou tácitas de uma determinada comunidade.

Feyerabend (2011) é contra a separação da ciência em seus contextos de justificação e descoberta argumentando que o chamado progresso científico não poderia ser obtido sem elementos externos à ciência racionalizada como, por exemplo, a transgressão às regras estabelecidas no interior de uma determinada tradição científica. Segundo Feyerabend (2011): 
A prática científica não contém dois contextos movendo-se lado a lado; ela é uma complicada mistura de procedimentos, e defrontamo-nos com a questão de se essa mistura deveria ser deixada como está, ou se deveria ser substituída por um arranjo mais "ordenado". [...] Ora, vimos que a ciência, como a conhecemos hoje em dia, não poderia existir sem uma frequente desconsideração do contexto de justificação. [...] A conclusão é clara. [...] substituir a mistura por uma ordem que contém a descoberta, de um lado, e a justificação, do outro, teria arruinado a ciência: estamos lidando com uma prática uniforme cujos ingredientes são todos igualmente importantes para o desenvolvimento da ciência. Isso liquida a distinção (FEYERABEND, 2011, pg. 197).

Com isso, Feyerabend destaca a importância de elementos "irracionais" no decorrer da prática científica, sobretudo para o triunfo de uma tradição científica sobre outra, e se opõe à ideia de uma metodologia capaz de dar conta de explicar a atividade científica afirmando que a ciência não é uma tradição, mas muitas tradições com diversos padrões de avaliação parcialmente incompatíveis (FEYERABEND, 2011).

O reconhecimento da ciência como um conjunto de muitas tradições, práticas efetivas de comunidades, que se sucedem umas as outras ou que coexistem em diferentes domínios das ciências naturais é fundamental para a constituição da visão de ciência que leva em consideração as críticas à received view. A tradição será, nas palavras de Feyerabend, condição de acesso ao mundo, à realidade: "O mundo não nos é dado diretamente, temos de apanhá-lo pela mediação de tradições" (FEYERABEND, 2011).

As visões de ciências dos autores acima citados são semelhantes em diversos pontos. Gostaríamos de destacar que todos eles se opõem à redutibilidade da atividade científica a um determinado conjunto de regras e que preferem conceber as ciências em termos de práticas e tradições heterogêneas que se assemelham entre si, mas das quais não se pode extrair nenhuma essência ou conjunto de características comuns. Inspirado no conceito de semelhanças de família de Wittgenstein, Kuhn (2017) afirma que as ciências guardam uma relação de semelhança:

O que [as ciências] têm em comum não é o fato de satisfazer as exigência de algum conjunto de regras, explícito ou passível de uma descoberta completa - conjunto que dá à tradição o seu caráter e a sua autoridade sobre o espírito científico. Em lugar disso, podem relacionar-se por semelhança ou modelando-se numa ou noutra parte do corpus científico que a comunidade em questão já reconhece como uma de suas realizações confirmadas (KUHN, 2017, pg. 118).

Azanha (2011) avalia a ambição de Bacon e Descartes de encontrar um único fundamento para toda a ciência como um equívoco que no lugar de permitir que captássemos algo de essencial à esta classe de práticas geraria a tendência de depreciação das práticas científicas reais que não se adequassem a este ideal de racionalidade científica: 


\begin{abstract}
O engano de todos aqueles que se empenharam nessa busca utópica foi o de imaginar que os modi operandi das ciências seriam redutíveis a um padrão formal de racionalidade. O núcleo desse engano foi a suposição de que a variedade das práticas científicas concretas teria algo de comum e essencial quando, na verdade, há entre elas apenas um "ar de família".

[...] não há um só grupo de regras que essencialmente permeie todas as práticas, mesmo se as considerássemos separadamente em grandes áreas (ciências humanas, biológicas e físicas).

[...] Mas - como disse Wittgenstein - o anseio de generalidade dos filósofos os faz manter uma atitude depreciativa com relação aos casos concretos nos seus esforços de uma compreensão geral do mundo. Da mesma maneira procedem aqueles que não levam em conta as práticas científica concretas porque imaginam que todas elas deveriam ajustar-se a um padrão geral e ideal de racionalidade científica (AZANHA, 2011, pg. 184).
\end{abstract}

É interessante notar que Azanha, inspirado em Wittgenstein, atribui a depreciação das práticas científicas concretas a um anseio por generalidade. Tal anseio, detectado por Wittgenstein em seus colegas filósofos, estava relacionado com o objetivo de fundamentar o empreendimento científico em um determinado padrão geral de racionalidade. A tentativa de fundamentar a ciência em um determinado padrão de racionalidade fará das teorias do conhecimento científico mais parecidas com uma prescrição (como a ciência deve ser) do que com uma descrição (como a ciência é).

Feyerabend (2011) afirma que "não há maneira de delimitar "ciência" por meio de algo mais forte e mais coerente do que uma lista" e, em seguida, faz uma advertência para as consequências negativas do anseio dos filósofos por uma visão uniformizada da ciência ao passo que reconhece que tal visão poderia ser benéfica para as comunidades científicas:

\footnotetext{
... uma "visão científica de mundo" uniforme pode ser útil para as pessoas fazendo ciência - dá-lhes motivação sem amarrá-las. É como uma bandeira. Embora apresente um único padrão, faz que as pessoas façam muitas coisas diferentes. Contudo, é um desastre para os de fora (filósofos, místicos indignos de confiança, profetas de uma Nova Era). Sugere a eles um comprometimento religioso da mentalidade mais estreita e encoraja uma estreiteza de mentalidade por parte deles (FEYERABEND, 2011, pg. 317).
}

Recorrendo a um estilo mais agressivo, Feyerabend adverte os filósofos, cientistas e filósofos das ciências contra uma visão dogmática de ciência tolerada e até desejada em nome de uma descrição geral capaz de dar conta da prática científica como um todo.

Recorremos à Thomas Kuhn e Paul Feyerabend por entender que estes autores representam uma reação muito mais ampla à Received View que, como dissemos, assimilou perfeitamente a distinção entre "contexto de descoberta" e "contexto de justificação" proposta por Reichenbach. A escolha desses autores se justifica pela popularidade que seus nomes alcançaram em discussões acerca das ciências e, também, porque foi a escolha realizada por José Mário Pires Azanha, referencial central neste trabalho. No entanto, 
reconhecemos as limitações destes autores e fazemos nossa a nota de rodapé inserida por Azanha com relação a esta decisão. Segundo Azanha (2011):

... são notórias, já há algum tempo, as imensas dificuldades teóricas e factuais que Kuhn tem encontrado para justificar historicamente os conceitos chaves de paradigma e de revolução científica. Além disso, ele e Feyerabend nunca conseguiram uma adequada compatibilização entre as afirmações de incomensurabilidade de teorias em competição e a inegável existência de progresso científico (AZANHA, 2011, pg. 170).

A ideia de que exista uma única racionalidade por trás do fazer científico é um ingrediente fundamental da Received View. Para seus representantes, a atividade científica poderia ser reduzida a um conjunto de regras que, uma vez observadas, conduziriam a produção de conhecimento seguro. Além disso, os representantes desta visão de ciência defendem a possibilidade de explicitar quais seriam esses procedimentos comuns à toda atividade científica. Azanha (2011) afirma que esta concepção de ciência, em que ações se reduzem ao seguimento de regras, é uma simplificação falsificadora:

... a prática científica, em qualquer campo, abrange atividades como a proposição de problemas, a construção de teorias ou hipóteses, a formulação de conceitos, a observação, a invenção de instrumentos etc. No âmbito dessa variedade de tarefas há, evidentemente, um amplo espaço para a criatividade do cientista; por isso, seria uma simplificação falsificadora conceber a prática científica como um espaço onde as ações se reduzem sempre ao seguimento de regras. [...] Estas [as regras] apenas indicam quais são os movimentos permitidos, proibidos ou exigidos, mas nunca garantem o êxito (AZANHA, 2011, pg. 183).

No lugar de uma visão de ciência como uma atividade altamente regrada e cujo êxito depende exclusivamente da observação de um corpo de regras bem definidas, Azanha (2011) sugere que o êxito da prática científica esteja relacionado, em parte, à criatividade do cientista ao, por exemplo, propor problemas e construir teorias e hipóteses. Para defender o papel da subjetividade do cientista no êxito da investigação científica, o autor observa que mesmo que, do ponto de vista lógico, a ocorrência de um evento possa ser relacionada com infinitas hipóteses, isso não ocorre. Frequentemente os cientistas levantam apenas algumas poucas hipóteses mais diretamente relacionadas às tradições de pesquisa às quais foram inseridos (AZANHA, 2011).

Azanha (2011) ainda recorre à noção de abdução de Peirce para considerar o papel da subjetividade do cientista na produção do conhecimento científico extrapolando, assim, a função logicamente determinada da dedução e da indução. Sobre o conceito de abdução, Azanha (2011) comenta que:

A definição que Peirce dá de abdução é singela e pouco esclarecedora:

"Abdução é o processo de formação de uma hipótese explanatória. É a única operação lógica que apresenta uma ideia nova [...] a Abdução 
simplesmente sugere que alguma coisa pode ser". (PEIRCE, 1999 apud AZANHA, 2011, pg. 156)

Ainda que sejamos capazes de persuadir o leitor racionalista de que a subjetividade do cientista desempenhe um papel importante na prática científica, encontraremos outra objeção à nossa ideia de que o fundamento da possibilidade do conhecimento científico seja a própria prática das diferentes comunidades científicas, a saber, a crença na existência de uma única lógica como guia e juiz das escolhas dos cientistas no interior de suas comunidades. Esta crença não corresponde à concepção de ciência que adotamos.

A visão de ciência subjacente a este trabalho considera a possibilidade de diferentes lógicas, diferentes conjuntos de axiomas e procedimentos de inferência, que se apresentem como necessários no interior das diversas práticas científicas. Nesta visão, a lógica não seria uma estrutura universal e a priori que reflete a estrutura do mundo, da linguagem ou da mente humana mas, antes, uma sistematização possível dos critérios de inferência ensinados e aprendidos por meio de processos de treinamento. Feyerabend (2011) relativiza o lugar privilegiado da lógica chamando nossa atenção para o fato de que ela é fruto de processos de ensino:

\begin{abstract}
Ninguém sustentaria que ensinar crianças pequenas é exclusivamente uma questão de argumentação [...] e quase todos, atualmente, concordam que o que parece ser um resultado da razão - o domínio de uma língua, a existência de um mundo perceptual ricamente articulado, a capacidade lógica - é devido, em parte, à doutrinação e, em parte, a um processo de desenvolvimento que age com força de uma lei natural (FEYERABEND, 2011, pg. 39).
\end{abstract}

Neste trecho, Feyerabend parece utilizar doutrinação em um sentido próximo ao que Wittgenstein utiliza treinamento. Em seguida, o autor defende a ideia de que não existe uma primazia da compreensão com relação à ação, se aproximando da defesa de Azanha de que o saber fazer não é um saber que aplicado à ação, e enfatizando que, tanto em crianças como em adultos, a utilização da linguagem, de argumentos, se dá de forma complexamente integrada com a atividade nas quais as palavras são utilizadas. Segundo Feyerabend (2011):

\footnotetext{
Admite-se com frequência como certo que uma compreensão clara e distinta de novas ideias precede, e deve preceder, sua formulação e sua expressão institucional. Primeiro temos uma ideia, ou problema; depois é que agimos, isto é, ou falamos, ou construímos, ou destruímos. Contudo, certamente não é esse o modo pelo qual se desenvolvem as crianças pequenas. Elas usam palavras, combinam-nas, brincam com elas, até apreenderem um significado que estivera, até então, além de seu alcance. E a atividade lúdica inicial é um pré-requisito essencial para o ato final de compreensão. Não há razão alguma pela qual esse mecanismo devesse deixar de funcionar no adulto (FEYERABEND, 2011, pg. 40).
} 
Algumas considerações sobre a relação do trecho acima com a lógica e o sentido são necessárias. Em primeiro lugar, se deve destacar a semelhança das considerações feitas por Feyerabend com àquelas relacionadas ao treinamento das crianças que nascem na comunidade fictícia onde todo o uso da linguagem está relacionado com a atividade de deslocar pedras para a construção de um edifício. Nas duas situações o sentido das palavras é concebido em estreita relação com as atividades dentro das quais estas palavras são apresentadas e utilizadas, os jogos de linguagem em que as crianças são introduzidas e, portanto, o sentido está estritamente relacionado com as formas de vida em que ocorrem.

Em segundo lugar, podemos aproveitar as reflexões presentes no último trecho de Feyerabend para defender que a própria lógica, a própria racionalidade, tem seu sentido estabelecido no interior dos jogos de linguagem de que fazem parte e, portanto, seu caráter de necessidade está fundamentado nas formas de vida em que estão presentes. Sendo assim, faz todo o sentido admitir a possibilidade de que, para diferentes formas de vida, ou comunidades de prática, possam existir diferentes sentidos para o que se considera lógica, ou seja, diferentes critérios de inferência baseados em diferentes axiomas.

Aceitando a premissa de que podem existir diferentes lógicas complexamente entrelaçadas com o fazer científico em diversas sub-áreas, podemos tirar uma consequência que, talvez, soe desconfortável para o racionalista, a saber, a de que o progresso científico pode ocorrer através de processos "ilógicos" quando por lógica concebemos um determinado sistema de axiomas e regras de inferência. Feyerabend (2011) afirma que são poucos os filósofos capazes de encarar essa consequência:

Apenas poucos filósofos estão preparados para conceder que as estruturas básicas subjacentes a algum idioma recém-descoberto podem diferir radicalmente das estruturas básicas dos sistemas mais familiares da lógica formal, e absolutamente ninguém está preparado para admitir que isso poderia ser verdadeiro também para a ciência (FEYERABEND, 2011, pg. 248).

Feyerabend fez esta afirmação em um contexto específico da história da ciência mas, no entanto, não nos parece absurdo considerar que, ainda hoje, a maioria dos filósofos da ciência e cientistas sejam incapazes de conceber a possibilidade de que certos procedimentos ou práticas científicas não se enquadrem perfeitamente em formalizações lógicas conhecidas. Em parte, isso pode estar relacionado com o fato de que comumente se atribui a uma lógica o fundamento do conhecimento científico.

A Received view atribui um papel tão fundamental a uma lógica universal e a priori que o mero levantamento dessas questões pode ser encarado como um ataque à instituição científica. O racionalista não concebe a possibilidade de questionar a necessidade de um fundamento na lógica sem questionar o empreendimento científico. Feyerabend (2011), no entanto, adota um ponto de vista diferente e defende que a recorrência a processos "ilógicos" é necessária para o progresso científico: 


\begin{abstract}
Não lhe ocorre [ao lógico] de modo algum que as "imperfeições" possam ter uma função positiva, e que o progresso científico possa ser impossível caso sejam afastadas. Para ele, a ciência é uma axiomática mais teoria de modelos, mais regras de correspondência, mais linguagem observacional. [...] a abordagem do lógico afasta não só os ornamentos dispensáveis da ciência, mas também os próprios aspectos que tornam possível o progresso científico e, portanto, a ciência (FEYERABEND, 2011, pg. 248).
\end{abstract}

Fica claro que, para Feyerabend, não só não existe uma única lógica que fundamente o fazer científico e a possibilidade do conhecimento como que a existência de procedimentos e decisões "ilógicas", no sentido de inadequadas a uma certa concepção de lógica, é condição necessária para o progresso científico e, portanto, para a ciência. Feyerabend argumenta que, em certos momentos do desenvolvimento científico, tanto a experiência como a lógica podem ser negligenciadas pelo cientista em sua atividade e, portanto, nem a lógica e nem a experiência podem limitar a especulação, a criatividade, dos cientistas (FEYERABEND, 2011). Isso não significa dizer que a experiência e a lógica não sejam importantes para a atividade científica mas, antes, que a especulação do cientista pode, inclusive, propor novas formas de experimentar e novas racionalidades. O fundamento da atividade científica é, como já dissemos, a própria prática científica.

Concebemos a prática científica como uma totalidade em que a razão, a experiência, a linguagem, os procedimentos, os critérios, os valores estão complexamente relacionados e, nesse sentido, prática e razão constituem partes de um único processo dialético. Segundo Feyerabend (2011):

\begin{abstract}
Embasar padrões em uma prática e deixar as coisas por isso pode perpetuar para sempre as deficiências dessa prática. [...] Isso sugere que razão e prática não são dois tipos diferentes de entidade, mas partes de um único processo dialético. [...] O viajante usa o mapa para descobrir o seu caminho, mas também o corrige à medida que procede, eliminando velhas idealizações e acrescentando novas. [...] a razão sem a orientação de uma prática vai induzir-nos ao erro, ao passo que uma prática é grandemente aperfeiçoada pelo acréscimo da razão (FEYERABEND, 2011, pg. 284).
\end{abstract}

Aproximando-se de uma concepção wittgensteiniana da linguagem, Feyerabend, mais uma vez, investe contra o lugar privilegiado conferido à razão e às regras colocando-as lado a lado com as demais formas de uso da linguagem. Segundo Feyerabend (2011):

Mesmo os mais perfeitos padrões ou regras não são independentes do
material sobre o qual agem [...] e dificilmente poderíamos entendê-los ou
saberíamos como usá-los se não fossem partes bem integradas de uma
prática ou tradição bastante complexa e, por vezes, bastante opaca, a
saber, a linguagem na qual o defensor rationis expressa seus implacáveis
comandos (FEYERABEND, 2011, pg. 285).

Aqui fica evidente que, para Feyerabend, as diferentes análises lógicas, as inferências lógicas, são práticas com a linguagem, ou seja, determinados jogos de linguagem nos quais 
os praticantes são introduzidos e levados a incorporarem as regras explícitas e tácitas de uso das palavras e que estão condicionados, portanto, por elementos da gramática da linguagem ordinária de um povo e elementos da gramática específica das diferentes tradições em lógica. As regras de uso das palavras, além de orientarem a ação, se cristalizam na ação e, ainda, podem ser constituídas e modificadas na ação. Segundo Wittgenstein (2000):

Podemos muito bem imaginar que pessoas se divertem num campo jogando bola e de tal modo que comecem diferentes jogos existentes, não joguem muitos deles até o fim, atirem a bola etc. Então alguém diz: durante todo o tempo aquelas pessoas jogaram um jogo e se comportaram, a cada jogada, segundo determinadas regras.

E não se dá também o caso em que jogamos e - 'make up the rules as we go along'? E também o caso em que as modificamos - as we go along (WITTGENSTEIN, 2000, § 83).

Contrariando a visão, expressa pelo racionalista, de que as mudanças de paradigmas nas ciências ocorrem segundo critérios lógicos de comparação entre duas ou mais teorias em disputa, Kuhn chama a atenção para o fato de que raramente os cientistas consagrados são convertidos aos novos paradigmas, mas, antes, que é mais comum que mantenham-se fiel à sua antiga visão e ofereçam resistência ao paradigma revolucionário. A revolução científica ocorre através da adoção do paradigma revolucionário pelas novas gerações de cientistas que se encontram menos comprometidos com o paradigma vigente, ou seja, são a troca de gerações de cientistas e o processo de formação acadêmica que possibilitam a consolidação de novos paradigmas científicos (KUHN, 2017). Segundo Kuhn (2017):

O homem que adota um novo paradigma nos estágios iniciais de seu desenvolvimento frequentemente adota-o desprezando a evidência fornecida pela resolução de problemas. Dito de outra forma, precisa ter fé na capacidade do novo paradigma para resolver os grandes problemas com que se defronta, sabendo apenas que o paradigma anterior fracassou em alguns deles. Uma decisão desse tipo só pode ser feita com base na fé (KUHN, 2017, pg. 258).

Essa reflexão acerca da adoção de paradigmas pelos estudantes em processo de formação assemelha-se à etapa de preparação da linguagem que descrevemos no capítulo anterior. Nesta fase, os estudantes se veem diante da necessidade de aceitar ou não uma série de convenções teóricas que fundamentarão posteriores resoluções de problemas, programas de pesquisa, interpretação de resultados etc. Longe de terem condições de avaliar, logicamente, as diferentes características de cada teoria que se apresenta como alternativa os estudantes são levados a apostarem em uma ou outra para, então, serem capazes de empreender investigações. Em outras palavras, há aqui um importante papel da persuasão para a introdução dos aprendizes em determinadas tradições de pesquisas científicas cujas práticas podem incorporar diferentes formas de experiência e razão. 
Uma das crenças subjacentes à algumas visões racionalistas da ciência consiste na possibilidade de separação radical entre "fato" e "interpretação". Segundo esta crença, seria possível observar fatos puros através dos órgãos do sentido ou de instrumentos de medição projetados com este propósito para, em seguida, interpretar esses fatos à luz de uma ou outra teoria. Dessa forma, muitas interpretações seriam possíveis e, portanto, caberia questioná-las enquanto nenhum questionamento poderia se dirigir aos próprios fatos visto que são concebidos como dados do mundo obtidos inequivocamente a partir da experiência empírica.

Neste ponto, tanto Kuhn como Feyerabend fazem uma série de considerações que, em nossa visão, convergem para o mesmo ponto, a saber, que a experiência empírica é possibilitada pela teoria e de que os fatos são, portanto, construções teóricas. Segundo Kuhn (2017):

\begin{abstract}
Teoria e fatos científicos não são categoricamente separados, exceto talvez no interior de uma tradição de prática científica normal. É por isso que uma descoberta inesperada não possui uma importância simplesmente fatual. O mundo do cientista é tanto qualitativamente transformado como quantitativamente enriquecido pelas novidades fundamentais de fatos ou teorias (KUHN, 2017, pg. 67).
\end{abstract}

No trecho, acima citado, Kuhn explicita sua visão de que teorias e fatos científicos possuem estreita relação e, sugere que a separação categórica entre os dois somente seria possível no interior de uma determinada tradição de ciência que, uma vez estabelecida, elege um conjunto daqueles que seriam os fatos sobre os quais tal tradição diz respeito e se fundamenta. Essa relação forte entre fatos e teorias no interior de uma tradição científica pode ser percebida na asserção do autor de que uma descoberta inesperada produz impactos significativos na teoria e, inclusive, na coleção de fatos considerados fundamentais para a tradição. Diante de uma descoberta inesperada, o cientista é convidado a reformular a teoria e, possivelmente, atualizar os fatos reconhecidos pela teoria. Ainda sobre a não separação entre teoria e fato, Feyerabend (2011) afirma que:

\footnotetext{
Para começar, devemos ter clareza a respeito da natureza do fenômeno total: aparência mais enunciado. Não há dois atos - um notar um fenômeno; o outro, expressá-lo com auxílio do enunciado apropriado -, mas apenas um, a saber, dizer, em certa situação observacional, "a Lua está me seguindo" ou "a pedra está caindo verticalmente" [...] descrever uma situação familiar é, para o falante, um evento em que enunciado e fenômeno estão firmemente aglutinados (FEYERABEND, 2011, pg. 88).
}

Neste trecho, Feyerabend defende que a natureza do fenômeno contém, simultaneamente, elementos da percepção e elementos da interpretação explicitados através do enunciado que pretende descrever o fenômeno. A frase "a pedra está caindo verticalmente" não é, pois, a explicitação fiel de um fato do mundo acessado através da percepção, mas, 
antes, uma organização da experiência por meio de instrumentos convencionais da linguagem que são frutos do processo de ensino. Sobre isso, Feyerabend se manifesta lembrando em muito - a concepção de linguagem de Wittgenstein. Para Feyerabend (2011):

\begin{abstract}
Essa unidade é o resultado de um processo de aprendizado que começa na infância. Desde nossos primeiros dias aprendemos a reagir às situações por meio das respostas apropriadas, linguísticas ou outras. Os processos de ensino tanto moldam a "aparência", ou "fenômeno", quanto estabelecem uma firme conexão com palavras, de modo que, no final, os fenômenos parecem falar por si mesmos, sem auxílio externo ou outros conhecimentos. Eles são o que os enunciados associados asseveram que sejam (FEYERABEND, 2011, pg. 88).
\end{abstract}

Feyerabend retoma sua afirmação de que nosso acesso ao mundo se dá por meio de uma tradição e é, portanto, mediado. Essa instância mediadora se estabelece no sujeito por meio da aprendizagem, da introdução dos aprendizes nas dinâmicas da etapa preparatória da linguagem e se consolidam na medida em que os aprendizes fazem aplicações corretas das palavras ensinadas. Os enunciados dos fatos parecem estar despidos de interpretação e explicitar os fatos tais como são, porque, normalmente, esquecemos as convenções linguísticas que aceitamos nesta etapa preparatória e que possibilitam a descrição que fazemos (MORENO, 1995). No entanto, a descrição de fatos sempre estão sustentadas em nossas convenções, numa gramática dos usos das palavras. Segundo Feyerabend (2011):

\begin{abstract}
A linguagem que "falam", é claro, é influenciada pelas crenças de gerações anteriores, crenças mantidas há tanto tempo que não mais aparecem como princípios separados, mas penetram nos termos do discurso cotidiano e, após o treinamento prescrito, parecem emergir das próprias coisas (FEYERABEND, 2011, pg. 89).
\end{abstract}

Uma vez introduzidos em determinada tradição de pesquisa científica, os membros desta comunidade tendem a reconhecer uma certa coleção de fatos, demonstrações e procedimentos paradigmáticos. Com o estabelecimento de determinado paradigma científico, as escolhas realizadas na situação de revisão da teoria antiga para a proposta de uma nova são naturalizadas e podem passar a ser compreendidas como necessárias: descrições de experiências serão compreendidas como expressão de fatos da natureza tais como se apresentam e certos procedimentos de verificação e inferência como constituintes do fazer científico. Esta estreita relação entre os fatos, fenômenos, experimentos, demonstrações e regras de inferência de uma determinada tradição condiciona, inclusive, a própria elaboração de problemas, hipóteses e instrumentos de medida. Segundo Feyerabend (2011):

O aparato conceitual da teoria, o qual vai lentamente emergindo, logo começa a definir seus próprios problemas, e os problemas, fatos e observações anteriores são ou esquecidos ou postos de lado como irrelevantes [...] Por que não deveria antes proceder a sua própria maneira, delineando suas próprias tarefas e constituindo seu próprio domínio de "fatos"? 
Afinal de contas, supõe-se que uma teoria abrangente contenha também uma ontologia que determina o que existe e, assim, delimita o domínio de fatos possíveis e questões possíveis (FEYERABEND, 2011, pg. 205).

Se por uma lado uma teoria a priori sobre a possibilidade do conhecimento científico não faz justiça às práticas efetivas das diversas ciências e suas sub-áreas, por outro, a experiência só é possível a partir de um referencial teórico que permita a organização de nossas percepções. Com isso, reforçamos que prática científica, racionalidade e experimentação são partes de um mesmo processo dialético. Feyerabend (2011), fazendo referência a Whorf, enfatiza o papel da gramática, de uma certa visão de mundo, como modeladora da percepção, da experiência:

as línguas e os padrões de reação que envolvem não são meros instrumentos para descrever eventos (fatos, estados de coisas), mas que são também modeladores de eventos (fatos, estados de coisas), que sua "gramática" encerra uma cosmologia, uma visão abrangente de mundo, da sociedade e da situação do ser humano, que influencia o pensamento, o comportamento e a percepção (FEYERABEND, 2011, pg. 215).

É interessante notar o paralelo que esta afirmação sobre a influência do arcabouço teórico na percepção tem com a leitura de dados obtidos através de instrumentos de medidas projetados por cientistas com a finalidade de explorar os fenômenos de interesse da comunidade a que pertence. Feyerabend (2011) comenta que "Instrumentos de medida são construídos de acordo com leis, e as leituras que proporcionam são testadas sob o pressuposto de que essas leis são corretas" (FEYERABEND, 2011, pg. 296). Sobre os esforços em demonstrar um acordo entre teoria e natureza a partir de experimentos, Kuhn (2017) comenta:

\begin{abstract}
Essa tentativa de demonstrar esse acordo representa um segundo tipo de trabalho experimental normal que depende do paradigma [...] A existência de um paradigma coloca o problema a ser resolvido. Frequentemente a teoria do paradigma está diretamente implicada no trabalho de concepção da aparelhagem capaz de resolver o problema. Sem os Principia, por exemplo, as medições feitas com a máquina de Atwood não teriam qualquer significado (KUHN, 2017, pg. 92).
\end{abstract}

Como apresentamos, a partir de Azanha, Kuhn e Feyerabend, a atividade científica pode ser compreendida como um conjunto de diferentes comunidades de práticas que apresentam semelhanças entre si, mas que não são passíveis de uma descrição a partir de um conjunto exaustivo de regras comuns à todas. Nega-se a experiência pura e a lógica como fundamentos da prática científica argumentando que não existe experiência sem orientação de uma teoria e que podem existir diversas lógicas por trás das diferentes práticas científicas efetivas. Propõe-se que a ciência tenha seu fundamento na própria prática dos cientistas, prática esta compreendida como constituinte de um só processo 
dialético com a razão. Defende-se a razão como uma prática e a prática como regulada por uma lógica, ainda que implícita.

A prática científica - composta por teorias, lógicas, critérios de verificação, linguagem observacional, instrumentos de medida, procedimentos e atitudes - é uma tradição em que os aprendizes são introduzidos. Esta tradição configura-se como instância mediadora que permite nosso acesso à realidade que é, portanto, mediada. Apresenta-se uma visão de fato como construção dependente da tradição científica, e não como um dado da natureza, e condicionado pelo compartilhamento de certos pressupostos linguísticos ou teóricos entre os membros da comunidade científica. Tal compartilhamento se dá por meio da aceitação ou não do aprendiz com relação a estes pressupostos durante seu processo de formação.

Em seguida, tendo as reflexões de Kuhn como ponto de partida, vamos refletir sobre a importância da atividade de ensino na formação dos cientistas, sobre a possibilidade de o cientista ser capaz de ver o mundo de diferentes formas a partir de diferentes teorias e do risco de incorrer em um dogmatismo a partir da afirmação de uma certa concepção de método, fato e racionalidade que não permite a crítica.

É através do ensino que o aprendiz entra em contato com as convenções linguísticas que possibilitam o trabalho científico em determinada tradição. Nesta etapa são apresentados conceitos, regras de inferência, exemplos do que são considerados fatos, demonstrações, leis, experimentos etc. Nesta etapa, que identificamos como preparatória para o uso da linguagem científica, os professores apresentam - de forma implícita ou explícita - essas convenções e os aprendizes podem aceitá-las ou não. De qualquer forma, o elemento chave para essa aceitação - nesta fase - é o poder de persuasão do professor e não, como muitos gostariam de acreditar, critérios lógicos acerca do poder preditivo e explicador da teoria em questão quando comparada a outras. Segundo Kuhn (2017):

Aquele que lê um texto científico facilmente poderá considerar as aplicações como provas em favor da teoria, razões pelas quais devemos acreditar nela. Mas os estudantes de ciência aceitam as teorias por causa da autoridade do professor e dos textos e não devido às provas [... As aplicações mencionadas nos textos não são apresentadas como provas, mas porque aprendê-las é parte do aprendizado do paradigma que serve de base para a prática científica em vigor (KUHN, 2017, pg. 164).

Neste trecho, Thomas Kuhn chama a atenção para algo que, normalmente, passa despercebido quando refletimos sobre o processo de formação de futuros cientistas, a saber, o fato de que as aplicações da teorias, mesmo as "demonstrações", são apresentadas como paradigmas de como se deve, ou costuma, relacionar elementos da teoria com a prática experimental, a descrição de fenômenos e com os critérios de inferência. Não podem ser critérios de verificação da validade da teoria, uma vez que os aprendizes, possivelmente, estarão entrando em contato com os procedimentos canônicos da comunidade científica 
pela primeira vez, mas, antes, a apresentação de "como se deve proceder" para demonstrar algo no interior de uma tradição de pesquisa.

Voltamos a insistir no fato de que não bastaria definir conceitos, leis e regras metodológicas para garantir o êxito na atividade científica porque o fundamento da atividade científica é sua prática efetiva. Faltaria ainda compreender de que forma conceitos, ações, coleta de dados, procedimentos de análise e conclusões se relacionam no interior desta comunidade. Estes são os elementos tácitos da tradição convencionados durante o fazer científico efetivo e o processo de treinamento dos aprendizes. Sobre isso, Azanha (2011) comenta que:

\footnotetext{
... "ter um conceito" numa prática científica não se esgota em saber que tal coisa é o caso, embora algumas vezes esse saber proposicional seja pressuposto. "Ter um conceito" não se manifesta, pois, apenas por um desempenho verbal, mas exige também e, principalmente, a capacidade de operar com ele no âmbito de uma prática científica em toda a complexidade técnica e intelectual que essa operação possa representar. "Ter um conceito" é, portanto, basicamente, um saber como, um saber fazer, é ter o domínio de uma prática. E a prova de que um aprendiz tem um conceito só pode ser, nessas condições, estabelecida de uma maneira "tangível e pública" (AZANHA, 2011, pg. 180).
}

Azanha defende que mesmo o conceito, normalmente reconhecido como parte do aspecto teórico da ciência, está fortemente relacionado com uma prática, com a capacidade de operar com ele segundo uma tradição e que a posse de um conceito, sua compreensão, somente pode ser avaliada mediante critérios públicos pautados em como o aprendiz opera com ele. Assim, apenas os demais membros de uma comunidade de prática científica poderão corrigir o aprendiz no seguimento de determinada aplicação do conceito (AZANHA, 2011). Kuhn (2017) também sugere a relação do conceito com a prática afirmando que:

Os conceitos científicos que expressam só obtêm um significado pleno quando relacionados, dentro de um texto ou apresentação sistemática, a outros conceitos científicos, a procedimentos de manipulação e a aplicações do paradigma" (KUHN, 2017, pg. 239).

Através do processo de formação, os novos cientistas aprendizes são introduzidos em uma tradição e compartilham uma série de pressupostos linguísticos que orientarão sua prática futura como membros da comunidade. Tais pressupostos linguísticos, na medida em que são aceitos e utilizados no interior da comunidade, constituem uma rede de proposições gramaticais, ou seja, proposições de caráter normativo que constituirão as condições de sentido da linguagem utilizada para fazer ciência. Em suas reflexões sobre a linguagem, Wittgenstein chamou essa rede organizada de proposições gramaticais, ou crenças, de Gramática.

A gramática possui estreita relação com a forma de vida da qual emerge e é responsável por uma certa visão de mundo do cientista. Thomas Kuhn sustenta que, em 
períodos de revolução científica, o quadro de referência dos cientistas precisa ser alterado e suas percepções do mundo reeducadas. Segundo Kuhn (2017):

Um historiador perspicaz, observando um caso clássico de reorientação da ciência por mudança de paradigma, descreveu-o recentemente como "tomar o reverso da medalha", processo que envolve "manipular o mesmo conjunto de dados que anteriormente, mas estabelecendo entre eles um novo sistema de relações, organizado a partir de um quadro de referência diferente" [...] o cientista não retém, como o sujeito da gestalt, a liberdade de passar repetidamente de uma maneira de ver a outra (KUHN, 2017, pg. 169).

O cientista não é capaz de transitar entre duas maneiras de ver o mundo, como o sujeito da gestalt, porque sua visão de mundo depende de um complexo sistema que relaciona conceitos, leis, teorias, procedimentos, lógica de inferência, processos de verificação etc, constituindo, assim, uma tradição. A revolução científica é apresentada, aqui, como um processo no qual as condições de sentido mais elementares vão sendo substituídas por outras que possibilitarão uma nova visão de mundo, uma nova tradição científica, incluindo a constituição de uma nova coleção de fatos relevantes e paradigmáticos.

Acreditamos, a partir desta visão de ciência, que a cristalização de uma certa visão de mundo, de uma certa gramática, possa oferecer obstáculo à inovação científica e, portanto, inviabilizar ou dificultar o progresso das ciências. Sobre isso, Feyerabend afirma que muitos pensadores se opõem à inovação científica argumentando que os "fatos" não concordam com uma nova teoria quando, na verdade, "fatos" carregam cristalizações de certas maneiras de ver o mundo que privilegiam uma tradição antiga das ciências. Segundo Feyerabend (2011):

Fatos contém componentes ideológicos, concepções mais antigas que foram perdidas de vista ou que talvez jamais tenham sido formuladas de maneira explícita. [...] No caso de uma contradição entre uma teoria nova e interessante e uma coleção de fatos firmemente estabelecidos, o melhor procedimento, portanto, não é abandonar a teoria, mas usála para descobrir os princípios ocultos responsáveis pela contradição (FEYERABEND, 2011, pg. 94).

Feyerabend propõe, no trecho acima, que se reflita sobre os aspectos convencionais que sustentam a identificação dos fatos estabelecidos no interior de uma tradição científica para que, assim, se compreenda as mudanças gramaticais necessárias para a revolução científica, ou seja, para que se descreva os fenômenos do mundo empírico através de uma nova teoria com novos acordos linguísticos. 


\subsection{Karl Popper e o critério de demarcação da ciência}

Apresentamos, em seguida, algumas considerações de Karl Popper sobre o método científico. Concentramos nossa atenção em sua concepção de ciência como sistema hipotético-dedutivo de proposições testáveis por qualquer indivíduo e em suas reflexões sobre a imprecisão dos conceitos científicos.

Segundo Popper (2013), a ciência pode ser vista como um sistema hipotéticodedutivo de proposições. Tal sistema seria passível de testes por indivíduos que, por meio de diferentes formas, estão em busca de convicções particulares e, por meio destes testes, poderia ser falsificável. Para Popper, a principal característica da ciência seria sua propriedade de falsificabilidade, isto é, a possibilidade de que se possa conceber testes que afirme ou neguem a validade de um sistema de proposições sugerido.

Popper afirma que a defesa de uma certa definição para o conceito de ciência deve ocorrer em termos da fecundidade teórica que tal definição pode nos oferecer. Segundo Popper (2013):

... os diferentes critérios de demarcação [da ciência] representam apenas diferentes posições na disputa de opiniões, mas não podem resolver a contenda [...] Entretanto, em inúmeras ciências, preferimos uma definição a outras e isso não porque ela corresponde melhor a nossas inclinações subjetivas, mas por razões objetivas: nós nos decidimos a favor de uma definição por causa da fecundidade (teórica) (POPPER, 2013, pg. 430).

O argumento de Popper parte da consideração de que os conceitos são definidos segundo sua fecundidade teórica nas mais diversas ciências. Em outras palavras, os cientistas sabem que os conceitos podem ser concebidos de diferentes formas, mas, mesmo assim, escolhem determinadas definições tendo em vista as vantagens desta escolha para a pesquisa que pretendem empreender. O filósofo da ciência propõe, então, que nossa escolha pelo critério de diferenciação da atividade científica das demais atividades deva seguir a mesma lógica.

Longe de fundamentar a possibilidade da atividade científica apenas na lógica, Popper afirma que o que torna uma teoria falsificável não são apenas suas propriedades lógicas, mas, também, determinados procedimentos ou decisões metodológicas constituintes da prática científica, ou seja, a natureza do tratamento que a comunidade científica oferece a seus produtos e suas próprias práticas (POPPER, 2013).

Popper reflete sobre a relação entre a aplicação dos conceitos das ciências e seu uso nas proposições, bem como sobre as aplicações das proposições, aproximando-se das considerações que já fizemos tendo Kuhn, Feyerabend e Azanha como fundamento. Segundo Popper (2013): 
... é em geral impossível definir completamente conceitos, isto é, defini-los de tal modo que sua aplicação empírica seja determinada de maneira inequívoca [...] a aplicação de um conceito não é determinada por definição, mas a aplicação do conceito determina o que chamamos de sua "definição" ou seu "significado". Dito de outro modo: há apenas definições de uso [...] eles [os conceitos] são sempre definidos unicamente pelo modo como são utilizados em proposições [...] aquilo que chamamos normalmente de significado de um conceito é - justamente ao contrário - determinado pela aplicação das proposições nas quais os conceitos ocorrem.

Mas investigar esse modo de aplicação é a tarefa da metodologia (POPPER, 2013, pg. 436).

Popper parte de uma concepção de linguagem em que o significado do conceito científico seria dado pelos usos que dele se fazem em proposições da ciência para, em seguida, afirmar que o significado do conceito científico depende da aplicação das proposições em que o conceito ocorre e, portanto, da prática científica. Aqui há um deslocamento da ideia de que as propriedades lógicas do conceito definam suas aplicações para a ideia de que a prática científica é que confere significado ao conceito.

Apesar de Kuhn e Feyerabend utilizarem conceitos muito semelhantes aos de Wittgenstein durante suas análises e até fazerem referências explícitas ao filósofo das Investigações Filosóficas, acreditamos, fundamentados em Azanha, que uma aproximação entre Wittgenstein e Popper seria mais apropriada quando o assunto é ciência. Para Popper, se deveria estabelecer uma condição limite ${ }^{3}$ para a aplicação do termo "ciência" a um conjunto de metodologias, a saber, uma condição que impusesse a necessidade de que uma teoria científica fosse passível de falseamento por meio da verificação empírica de suas proposições (AZANHA, 2011). Segundo Azanha (2011):

O ponto que os aproxima [Wittgenstein e Popper] aqui é que, por diferentes razões, ambos rejeitaram o essencialismo. No que nos interessa - o conceito de método científico - numa linha wittgensteiniana de análise, a rejeição estaria no reconhecimento de que as variedades das práticas científicas concretas não extraem a sua cientificidade de um suposto ajuste a um significado essencial de racionalidade [...] Em Popper, a rejeição está no fato de que as práticas científicas concretas, que chegarem a considerar que uma teoria - qualquer que ela seja - é imune à critica, desqualificam-se como científicas, porque isso importa no abandono da busca permanente e na presunção de se ter alcançado uma verdade definitiva, o que é logicamente insustentável (AZANHA, 2011, pg. 186).

No lugar de assumir que "tudo vale" na atividade científica, como Feyerabend, ou que o "dogma" tem uma função importante na ciência, como Kuhn, preferimos a imposição de uma condição limite para a identificação da atividade científica, proposta por

3 Azanha chama essa condição limite de regra suprema e afirma que se trata de uma regra para a elaboração de outras regras da ciência, de forma que nenhum enunciado seja protegido contra a falsificação (AZANHA, 2011). 
Popper, que no lugar de descrever exaustivamente os fundamentos lógicos ou empíricos que sustentam a possibilidade do conhecimento científico, apenas propõe uma fronteira para o reconhecimento da atividade científica diante de todas as outras atividades regradas possíveis.

Destacamos, ainda, que essa escolha - também realizada por Azanha - permite que reconheçamos a possibilidade de diferentes práticas científicas com diferentes racionalidades sem, no entanto, carecer de um critério de reconhecimento do que viria a ser a atividade científica. Segundo Azanha (2011):

\begin{abstract}
... a contestação da Received View, isto é, da compreensão da ciência a partir de um ideal de sistematicidade lógica, não precisa conduzir-nos a um relativismo histórico quanto às questões da racionalidade.

O jogo da ciência, mesmo sendo sempre local e mutável como é próprio de todas as práticas sociais, não é um jogo irracional onde vale tudo e até o dogma tem cabida. A rejeição de um ideal absoluto de racionalidade da ciência apenas é o abandono de uma ilusão racionalista e o reconhecimento de que diferentes "formas de vida" podem incorporar diferentes formas de racionalidade (AZANHA, 2011, pg. 186).
\end{abstract}

A visão de ciência que nos guia pretende escapar de duas posturas com relação à ciência: o racionalismo que atribui a uma única racionalidade o fundamento último da ciência e apresenta uma definição restrita de ciência e da ideia de que tudo vale no empreendimento científico. Para isso, nos aproximamos das ideias de Karl Popper que, acreditamos, admite a centralidade do papel da prática das diferentes comunidades científicas para o empreendimento científico sem, no entanto, eximir-se de apresentar um critério mínimo de demarcação da ciência que permite a diferenciação de atividades científica e não científicas.

Essa critério mínimo, ou regra suprema, não pretende definir uma racionalidade científica, nem tampouco uma metodologia da ciência, mas - ao contrário - permite que um conjunto variado de racionalidades e metodologias sejam consideradas científicas contanto que respeitem uma condição, a saber, que apresentem a característica de serem passíveis de teste e falseamento.

\title{
3.3 Reflexões sobre a conservação da energia
}

Tendo discutido sobre alguns aspectos da visão de ciências que nos guia faremos, agora, uma breve reflexão sobre a importância da prática científica e, sobretudo, das engenharias na concepção do princípio de conservação da energia tendo como fundamento um texto chamado A conservação da energia como exemplo de descoberta simultânea de Thomas Kuhn. 
Neste texto, Thomas Kuhn argumenta que o princípio de conservação de energia foi enunciado por quatro cientistas - Mayer, Joule, Colding e Helmholtz - dispersos pelo território europeu, entre 1842 e 1847, sendo que três deles - Mayer, Joule e Colding trabalhavam em completa ignorância uns dos outros. Sua tese é de que isso foi possível devido à três fatores principais, a saber, a disponibilidade dos processos de conversão, o interesse dos intelectuais pelas máquinas e a popularização de uma visão de mundo conhecida como Naturphilosophie (KUHN, 1989).

Alguns eventos notáveis ocorreram anterioremente à enunciação do princípio de conservação da energia e, possivelmente, tenham ajudado na constituição das condições desta enunciação. Em 1800, Alessandro Volta produziu a pilha, viabilizando, assim, a conversão de fenômenos químicos para elétricos; a corrente elétrica produzia calor e, em determinadas condições, luz; no ano de 1820, Oersted relacionou fenômenos elétricos com magnéticos; o magnetismo era capaz de produzir movimento que, por sua vez, produzia eletricidade devido à força de atrito. Com isso, tinha-se uma sequência fechada de conversões de fenômenos (KUHN, 1989).

Em 1822, Seebeck produziu corrente elétrica fornecendo calor a um par bimetálico e, em 1834, Peltier mostrou que a corrente elétrica poderia ser utilizada para absorver calor e produzir frio. Em 1827, Melloni identifica o calor radiante com a luz relacionando mais dois aspectos da natureza vistos, até então, como separados (KUHN, 1989).

Esses e outros exemplos fornecidos por Thomas Kuhn possuem a finalidade de mostrar que diferentes processos de conversões foram sendo, gradualmente, forjados e relacionados entre si de maneira que se consolidaram possíveis circuitos fechados de transformação de fenômenos tipicamente químicos, térmicos, elétricos, magnéticos, óticos e dinâmicos em quaisquer outros dos tipos citados (KUHN, 1989).

Apesar de haver disponibilidade de diversos processos de conversão desde 1800, e mesmo antes disso, uma sistematização clara dos processos disponíveis, somente ocorreu no ano de 1830 possibilitando, assim, uma visão panorâmica desses procedimentos conhecidos e o reconhecimento destes como processos de conversão (KUHN, 1989).

Kuhn apresenta uma obra de Mary Sommerville, datada de 1834, como um ícone da mudança de como os físicos enxergavam a física. Segundo Kuhn (1989):

Problemas antes separados ganhavam múltiplas inter-relações, e era isso que Mary Sommerville tinha em mente quando, em 1834, deu à sua famosa obra de divulgação científica o título de On the Connexion of the Physical Sciences. "O progresso da Ciência moderna", ela diz no prefácio, "em especial nos últimos cinco anos, tem sido notável em sua tendência a [...] unir ramos separados [da ciência, de modo que hoje] [...] existe um tal laço de união que não se pode obter proficiência em um ramo sem o conhecimento dos demais." A observação de Sommerville delimita a "nova aparência" que a ciência física adquirira entre 1800 e 1835 . Essa nova aparência, em conjunto com as descobertas que a produziram, 
revelou-se uma das principais condições para o aparecimento da noção de conservação de energia (KUHN, 1989, pg. 110).

A sistematização dos diversos processos de conversão disponíveis, possibilitando uma visão panorâmica das relações entre as diversas áreas da física, ocasionou o fortalecimento de uma visão da física como ciência cujas sub-áreas estão intimamente relacionadas. Kuhn afirma que a ideia de conservação de energia seja uma contrapartida teórica dos processos laboratoriais de conversão, em que cada conversão laboratorial conhecida possui como correspondente teórico uma transformação na forma da energia (KUHN, 1989). Kuhn afirma que "a rede de processos de conversão de fato balizou o caminho experimental para a conservação da energia e, assim, forneceu a ligação essencial entre vários pioneiros" (KUHN, 1989, pg. 112).

O cenário, acima descrito, colaborou para a concepção da conversibilidade universal, ou seja, a noção de que os poderes naturais de diferentes tipos podem ser convertidos uns nos outros. No entanto, isso não é o mesmo que a ideia de conservação de energia. Dois expedientes filosóficos, comuns na época, colaboraram com a concepção da conservação da energia, a saber, a igualdade entre causas e efeitos e a impossibilidade do movimento perpétuo. Em outras palavras, se o que é causa em um momento, corrente elétrica que gera calor, é efeito em outro, corrente elétrica gerada por calor, então causas e efeitos devem possuir a mesma natureza. Se possuem a mesma natureza, torna-se necessário que exista uma equivalência quantitativa entre causa e efeito, senão haveria a criação de forças ou poderes nesses processos e, então, o movimento perpétuo seria possível (KUHN, 1989).

O passo necessário para a elaboração do princípio de conservação da energia seria a correlação quantitativa entre as forças de diferentes naturezas. Kuhn, citando Groove, comenta:

\footnotetext{
Groove sabia o que estava dizendo: "O grande problema que ainda espera ser solucionado, no que tange à correlação das forças físicas, é o estabelecimento de seu equivalente de poder, ou de sua relação mensurável com um dado padrão". Os fenômenos de conversão não poderiam levar os cientistas mais longe do que isso no caminho para a enunciação da conservação da energia (KUHN, 1989, pg. 115).
}

A solução do problema enunciado por Groove só foi possível na medida em que os cientistas interessados nos processos de conversão se familiarizaram com elementos da tradição da engenharia do século XIX como, por exemplo, as máquinas e motores de água, vento e vapor e o conceito de efeito mecânico ou trabalho (KUHN, 1989). O conceito de trabalho, empregado como o produto da força pela distância, somente assumiu um papel importante na teoria da dinâmica em 1782:

Foi apenas em 1782, no Essai sur les machine en général, de Lazare Carnot, que o produto da força pela distância passou a ter um nome e 
uma prioridade conceitual na teoria dinâmica. Mas essa nova concepção dinâmica do conceito de trabalho não foi realmente empregada ou difundida antes de 1819-1839, quando recebeu plena expressão nas obras de Navier, Coriolis, Poncelet e outros (KUHN, 1989, pg. 121).

O conceito de trabalho, extraído da tradição da engenharia das máquinas e motores, foi fundamental para a enunciação da conservação da energia. Há razões para acreditar que isso somente foi possível devido à capacidade dos cientistas em reconhecer as máquinas e motores como expedientes de conversão e, por isso, a transferência de conceitos da engenharia para a análise dos processos de conversão como adequada (KUHN, 1989). Segundo Kuhn:

Dos nove pioneiros que lograram, completa ou parcialmente, quantificar os processos de conversão, todos eles, com exceção de Mayer e Helmholtz, eram formados em engenharia ou trabalhavam diretamente com máquinas quando deram suas contribuições à conservação da energia. Dos seis que calcularam valores independentes para o coeficiente de conversão, todos, com exceção de Mayer, estavam envolvidos diretamente com máquinas ou tinha formação na área. Para realizar seus cálculos, precisavam do conceito de trabalho, e a fonte desse conceito era, sobretudo, a tradição da engenharia (KUHN, 1989, pg. 124).

Dissemos que a enunciação do princípio de conservação da energia, segundo Thomas Kuhn, foi viabilizada por três fatores principais. Decidimos focar em dois destes fatores para nossa análise, a saber, a disponibilidade de diversos processos de conversão de fenômenos das diferentes sub-áreas da física para quaisquer outros e o interesse dos cientistas nas problemáticas relativas às máquinas e seus rendimentos. Para a quantificação dos processos de conversão e, portanto, para a concepção final da conservação da energia foi necessária a utilização do conceito de trabalho (o produto da força pela distância), muito utilizado na tradição da engenharia, no contexto da pesquisa científica. Afirmamos, ainda, que as máquinas térmicas foram vistas pelos cientistas como modelos de processos de conversão o que, em nossa opinião, facilitou a transferência do conceito de trabalho, dentre outros, da engenharia para a análise dos processos de conversão na física e, posterior, elaboração do princípio de conservação da energia.

Apesar de o conceito de trabalho ter sido fundamental para a formulação da conservação da energia defendemos que a definição de energia como a "capacidade de um corpo realizar trabalho" seja insuficiente para dar conta de todos os usos deste conceito no interior de diversas áreas da física. Segundo Duit:

Quando a segunda lei da termodinâmica foi estabelecida, ficou claro que nem toda energia é capaz de realizar trabalho. Por esta razão, Planck previu no início do século 20 que essa tradicional maneira de introduzir o conceito de energia associada ao conceito de trabalho desapareceria em vinte anos. (DUIT, 1986 apud DOMéNECH et al., 2007, pg. 49) 
O ponto de Planck era o de que, na segunda lei da termodinâmica, se afirma que nem toda energia que entra em uma máquina é passível de ser convertida em trabalho, ou seja, parte dessa energia simplesmente deverá atuar na manutenção do ciclo da máquina e seu fluxo se dá da fonte quente para a fonte fria sem realização de trabalho mecânico.

No próximo capítulo, exploramos mais características do conceito físico de energia levando em conta o conhecimento publicado na literatura sobre o ensino do conceito nas disciplinas de ciências da educação básica.

\subsection{Síntese do capítulo e consequências para este trabalho}

Na medida em que tentamos sintetizar o conteúdo deste capítulo, apresentamos, a seguir, alguns resultados apresentados por Azanha, Laudan, Kuhn, Feyerabend e Popper em itálico - e, em seguida, um conjunto de consequências para o desenvolvimento deste trabalho.

I) Não há apenas um método científico. A ciência é o conjunto das práticas adotadas pelos cientistas enquanto realizam experimentos e constroem teorias (LAUDAN, 2000). Essas práticas se relacionam por semelhanças e não por essência (KUHN, 2017): A aplicação do conceito de energia estará submetida à regulação de gramáticas diversas na medida em que estas aplicações ocorram em diferentes ramos da ciência ou da física.

II) A ciência não é apenas um conjunto de proposições hipotéticas sobre o mundo, mas, também, observações, equipamentos experimentais, relação intuitiva entre observadores e instrumentos, critérios de decisão, etc (FEYERABEND, 2011): Em cada contexto de aplicação, o conceito de energia estará relacionado com diferentes equipamentos de observação, diferentes tradições de investigação, critérios de decisão, etc.

III) Os elementos linguísticos, conceituais, proposicionais das teorias científicas possuem íntima relação com os elementos procedimentais, culturais e práticos da tradição científica (KUHN, 2017): Para a compreensão do papel do conceito de energia na ciência não importam apenas as afirmações feitas envolvendo o conceito de energia mas também as relações entre este conceito e todos os procedimentos e práticas científicas que nele se fundamentam ou que contribuíram com sua origem e constituição.

IV) Apesar de desempenhar um papel importante, a razão não é o fundamento último da ciência. Diferentes práticas científicas podem apresentar diferentes racionalidades (FEYERABEND, 2011): Apesar da transversalidade do conceito de energia em relação aos ramos da ciência, não podemos supor que exista uma única definição capaz de representar todos os usos possíveis e úteis deste conceito, mas, antes, podemos analisar quais as regras, gramáticas ou racionalidades que orientam a aplicação do conceito nos diferentes ramos da ciência. 
V) A atividade científica não se reduz ao seguimento de regras protocolares, mas inclui a criação de novas regras, a transgressão a certas convenções, a criatividade dos indivíduos pesquisadores (AZANHA, 2011): Novos usos podem ser inventados para o conceito de energia, assim como foram inventados novos usos a partir da revolução da termodinâmica estatística. Além disso, definições precisas e gerais podem ser propostas no interior da prática científica para que se alcance determinadas finalidades. Este parece ser o caso da definição geral de energia como quantidade que se conserva em meio aos processos de transformação.

VI) No processo de formação de cientistas, um conjunto de convenções ${ }^{4}$ é passiva e tacitamente aceito pelos jovens estudantes que, a esta altura, não possuem condições de julgar a conveniência de tais convenções. Apenas depois é que poderão, a partir deste conjunto de convenções iniciais, avaliar suas próprias limitações ou a conveniência de novas convenções (KUHN, 2017): Parte daquilo que os cientistas afirmam sobre o conceito de energia atualmente, por exemplo o princípio de conservação da energia, foi aceito durante o período de suas formações sem quaisquer tipos de procedimentos de verificação mas, antes, constituiu os paradigmas ${ }^{5}$ a partir dos quais os cientistas podem, atualmente, analisar e investigar os mais diversos fenômenos.

VII) Teorias e fatos científicos não são completamente independentes, pois a expressão dos fatos está assentada em certos pressupostos teóricos (KUHN, 2017) e (FEYERABEND, 2011): A gramática do conceito de energia é condição necessária para que os indivíduos sejam capazes de observar certos fenômenos, como a conversão de energia potencial gravitacional das águas de um rio em energia elétrica.

VIII) Ter um conceito é ter o domínio de uma prática (AZANHA, 2011): Saber o conceito de energia, no contexto científico ou escolar, é ser capaz de operar com o conceito em diversas situações previstas e, ainda, em outras situações não apresentadas pela atividade de ensino.

IX) Seria frutífero definir ciência como as atividades de produção do conhecimento que produz teorias falseáveis a partir da verificação de suas proposições (POPPER, 2013): De acordo com Azanha (2011), adotar este critério minimo de demarcação da atividade científica nos permite evitar definições dogmáticas a respeito do empreendimento científico sem cairmos em um relativismo onde qualquer atividade poderia ser reconhecida como científica. Ao definirmos um critério mínimo do que deve ser ciência, excluímos um conjunto de atividades cujo falseamento não é permitido por razões intrínsecas e deixamos de arbitrar a respeito das características específicas das atividades consideradas, por esta definição, científicas.

4 Aplicamos o conceito de convenção no sentido de regra de uso da linguagem tacitamente aceita no processo de ensino.

5 Aplicamos o conceito de paradigma no sentido kuhniano, sentido já explicitado ao longo deste capítulo. 
X) Esse critério mínimo de demarcação da atividade científica permite que as diversas práticas científicas sejam relativamente autônomas e apresentem suas próprias racionalidades e metodologias (AZANHA, 2011): O conceito de energia, contemporâneo, é fruto de um esforço teórico que emergiu de diversas tradições de pesquisa em física e engenharia, cada uma dessas tradições com suas próprias regras, conceitos e critérios embora assemelhadas umas às outras. Uma das características interessantes do conceito de energia é justamente a possibilidade de sua aplicação para a descrição e análise de fenômenos muito complexos e heterogêneos.

XI) O conceito científico de energia, atualmente, está fortemente relacionado com o princípio de conservação da energia (KUHN, 1989): Compreender o conceito científico de energia significa, inclusive, ser capaz de calcular a energia de diferentes sistemas, analisar os diferentes processos de transferência e transformação pelos quais a energia passa e, também, ver - a partir da gramática deste conceito - que a energia sempre se conserva em sistemas isolados.

XII) Historicamente, a enunciação do princípio de conservação da energia só foi possível graças à sistematização e popularização dos processos de conversões de "poderes" de diferentes naturezas uns nos outros. Além disso, o aspecto quantitativo - fundamental para este princípio - somente foi resolvido a partir da apropriação do conceito de trabalho, originalmente utilizado por engenheiros interessados em máquinas térmicas, por físicos (KUHN, 1989): A origem histórica do conceito de energia está intimamente ligada com as práticas de cientistas de diversas áreas e com engenheiros e, assim sendo, a gramática do conceito de energia possui diversos elementos oriundos destas tradições.

Evidenciamos, a partir das consequências apresentadas nesta seção, nossa intenção em destacar o papel da linguagem e das atividades a ela relacionadas no empreendimento científico. Em especial, procuramos destacar o papel da linguagem e das atividades ligadas à consolidação do princípio de conservação da energia na formação do conceito moderno de energia ${ }^{6}$. Para isso, confrontamos alguns dos pressupostos da received view, como por exemplo o da existência de uma única metodologia capaz de garantir a produção do conhecimento e de uma única razão como fundamento último da possibilidade do conhecimento. Assim, chamamos a atenção do leitor para a relevância de outros aspectos, como as atividades e técnicas habitualmente exercidas pelos membros da comunidade científica, para a possibilidade do conhecimento.

6 Com conceito moderno de energia nos referimos à concepção de energia intimamente ligada ao seu princípio de conservação. 


\section{O conceito de energia no contexto escolar}

Em seguida, realizaremos algumas reflexões sobre o conceito de energia nas aulas de física do ensino médio. Essas reflexões tem por objetivo mostrar que há uma imagem deste conceito que é privilegiada diante de outras possíveis, assim como avaliar as limitações desta imagem diante de determinados tipos de problemas da física escolar. Para isso, apresentamos dados provenientes de 3 fontes diversas: da análise de duas coleções de livros didáticos aprovados pelo PNLD 2015, da análise do material didático utilizado pelo professor da turma observada e dos dados coletados durante a aplicação de uma sequência didática elaborada e aplicada em conjunto com o professor da turma.

Os dados provenientes de cada uma dessas fontes possuem seu próprio sentido dentro desta pesquisa. Com os livros didáticos pretendemos oferecer um panorama daquilo que, oficialmente, viria a ser o ensino do conceito de energia no ensino médio. Mostraremos, com isso, as principais temáticas dentro das quais o conceito de energia costuma ser abordado, os aspectos do conceito que são enfatizados pelas coleções e os tipos de energia mais frequentemente trabalhados. Já com a análise do material didático utilizado pelo professor mostraremos os aspectos do conceito de energia trabalhados ao longo do primeiro semestre de 2017 pelo professor de física responsável pela turma acompanhada para que, à luz destas informações, analisemos os dados provenientes da sequência didática por nós aplicada em conjunto com o professor da turma. Além disso, destacaremos alguns elementos comuns às apresentações do conceito de energia nas coleções de livros didáticos e na apostila adotada pelo professor. Por fim, a sequência didática por nós aplicada terá como objetivo fornecer detalhes do processo de ensino do conceito de energia a partir da exploração de aspectos pouco abordados pelo professor durante o primeiro semestre.

\subsection{Alguns aspectos do conceito de energia}

Antes de apresentarmos nossas análises, apresentaremos alguns aspectos do ensino e da aprendizagem do conceito de energia - frequentemente documentados em pesquisas acadêmicas da área de ensino de ciências - através da sistematização oferecida por Doménech et al. (2007).

O conceito de energia é fundamental para a física atual e para as demais ciências. Numa visão moderna, podemos afirmar que o conceito de energia está intimamente ligado com o princípio de conservação da energia que Feynman, Leighton e Sands (2010) apresentam em suas lições da seguinte maneira: 
menos naturais dos quais temos conhecimento. Não há exceções para esta lei dentro dos limites do que conhecemos. Esta lei é chamada de conservação da energia. Ela afirma que há uma certa quantidade, que nós chamamos de energia, que não se altera durante as mudanças que ocorrem na natureza. Isto é uma ideia muito abstrata, porque se trata de um princípio matemático; a lei afirma que existe uma certa quantidade numérica que não se altera na medida em que as coisas acontecem. Não se trata de uma descrição de um mecanismo, ou qualquer coisa concreta; Trata-se apenas de um estranho fato: nós podemos calcular certa quantidade e quando terminarmos de observar o curso da natureza através de seus truques e calcularmos este número novamente, ele será o mesmo (FEYNMAN; LEIGHTON; SANDS, 2010, Capítulo 4, tradução nossa).

No trecho acima, Feynman apresenta a conservação da energia como um princípio matemático que afirma que uma certa quantidade, energia, se mantém constante através dos diversos processos naturais. De fato, como discutimos no capítulo anterior a partir das reflexões de Kuhn, o princípio de conservação da energia emergiu a partir de uma complexa teia de relações entre fenômenos das mais diversas naturezas e seu aspecto matemático foi fundamental para que se concebesse os diversos "poderes" - da eletricidade, da termodinâmica, da mecânica, etc - como entidades equivalentes. Segundo Bunge (1999):

Esta conservação quantitativa é a razão pela qual consideramos todas as quantidades de energia como equivalentes. Em outras palavras, a introdução do conceito geral de energia se justifica pelo princípio geral de conservação da energia (BUNGE, 1999, pg. 54, tradução nossa).

Se hoje discutimos o significado de energia quando levamos em consideração um conceito que se aplica às diversas áreas da física, ou mesmo de outras ciências, é porque o princípio de conservação da energia nos permitiu que, a partir de conceitos particulares e aplicáveis à determinados conjuntos de fenômenos, se concebesse um princípio geral que os relacionasse uns aos outros. Segundo Bunge (1999):

Cada conceito particular de energia se define em um capítulo da física. Por exemplo, a energia cinética se define na dinâmica; a térmica na termodinâmica; a eletromagnética na eletrodinâmica; e a nuclear na física nuclear. Cada um destes campos contém seu próprio conceito de energia. Mas mesmo assim, em todos estes campos, salvo na termodinâmica clássica, se demonstra um teorema de conservação da energia a partir das correspondentes equações de movimento ou de campo (BUNGE, 1999, pg. 54, tradução nossa).

Por um lado, Bunge reconhece que existam diversas concepções de energia, uma para cada área da física. Por outro, afirma que todos estes conceitos - com exceção da energia da termodinâmica clássica - se encontram no interior de teorias onde o princípio de conservação da energia é válido. Este aspecto geral do conceito de energia é que permite a análise e compreensão de fenômenos naturais complexos em termos energéticos. Segundo Bunge (1999): 
Para poder somar energias de dois ou mais tipos é preciso unir as disciplinas correspondentes. Por exemplo, a energia total de um jato de fluido carregado eletricamente (e portanto rodeado de um campo magnético) só pode ser calculada em uma ciência híbrida: a eletromagneto - termo - hidrodinâmica (que trás implicações para o estudo da atmosfera solar e para o desenho de complexos de fusão nuclear) (BUNGE, 1999, pg. 54, tradução nossa).

Como vimos na seção anterior, o conceito de energia e sua conservação surgiram da ânsia dos cientistas por compreenderem os diversos processos de conversão de fenômenos de determinadas áreas da física em fenômenos de outras e, inevitavelmente, se deu através do diálogo entre membros de distintas áreas da ciência de forma que os conceitos de energia particulares de cada área constituíram uma unidade coerente com os demais através do princípio de conservação.

Este processo de criação teórica promoveu a mudança das diversas áreas da física assim como impactou na forma com que os membros da comunidade científica decidiam calcular a energia no interior de suas próprias áreas. Este processo pode ter contribuído para uma hibridização ou relativa unificação entre estas áreas. A termodinâmica, por exemplo, só alcançou esta unificação na medida em que reconheceu seus fenômenos como sendo a contrapartida macroscópica de fenômenos microscópicos de natureza fundamentalmente mecânica ${ }^{1}$.

Em seguida, abordaremos algumas concepções do conceito de energia que colocam dificuldades frequentes e persistentes no que diz respeito ao ensino. Tais dificuldades se expressam através de, por exemplo, afirmações sobre o conceito de energia interpretadas dogmaticamente ou mesmo equivocadas, presentes nos materiais didáticos distribuídos pelo território nacional. São algumas delas:

1. A energia é algo contido em um corpo ou uma propriedade de um corpo

2. Energia nula é o mesmo que ausência de energia

3. A energia é a capacidade de um corpo realizar trabalho

4. O princípio de conservação da energia é uma generalização da conservação da energia mecânica

Enquanto as afirmações de números 1 e 2 representam afirmações equivocadas sobre o conceito de energia, as afirmações de números 3 e 4 são problemáticas quando dogmaticamente empregadas, ou seja, quando são apresentadas como características essenciais do conceito de energia encorajando, assim, generalizações indevidas com relação ao sentido do conceito nas mais diversas áreas da ciência. A aceitação, assimilação e propagação destas afirmações envolvendo o conceito de energia podem contribuir para uma determinada imagem do conceito de energia que, se empregada dogmaticamente, pode

1 Com o surgimento da mecânica estatística, os fenômenos da termodinâmica foram concebidos como efeitos do movimento e das colisões entre as diversas partículas que compõem as substâncias e corpos. 
constituir um obstáculo à compreensão do conceito no contexto das disciplinas escolares de ciências.

Para cada uma das afirmações sobre o conceito de energia relacionadas acima, apresentamos um aspecto do conceito de energia, consensual entre os cientistas, que evidencia a contradição entre as expectativas atuais para o ensino do conceito e as concepções mais frequentemente documentadas através da pesquisa educacional no ensino de ciências, a saber:

1. A energia é uma propriedade dos sistemas e não de corpos isolados

2. Energia nula é apenas um caso numericamente especial de energia em um dado referencial

3. A energia está associada às mudanças nos sistemas mas tais mudanças não podem ser reduzidas àquelas explicadas pelo conceito de trabalho

4. O princípio de conservação da energia só pode ser concebido tendo em consideração fenômenos e princípios das mais diversas áreas da física bem como suas relações

O primeiro aspecto das concepções problemáticas de energia que persistem no ensino de ciências é a visão de que a energia seja algo possuído pelos corpos. Esse algo pode ser interpretado como uma espécie de substância ou combustível armazenado nos corpos ou apenas como uma propriedade dos corpos. Estas concepções não condizem com duas das características do conceito de energia, tal como aplicado nas ciências: O fato de que a energia seja um conceito abstrato relacionado com o cálculo de um valor que se apresente como constante no decorrer dos processos naturais e o de que este valor sempre diz respeito a um sistema de corpos físicos e suas interações e, quase nunca, diz respeito a apenas um corpo isolado². Segundo Doménech et al. (2007):

Energia não é um tipo de combustível necessário para a produção de transformações, como os estudantes frequentemente concebem, mas uma capacidade de transformação determinada pela configuração de sistemas em interação e por propriedades da matéria responsáveis por estas interações. [...] Vários estudos têm mostrado que a maioria dos estudantes atribuem energia para corpos específicos e não para o sistema formado por um conjunto de objetos que interagem [...] Energia é uma propriedade de sistemas, e falar sobre a energia de objetos isolados carece de sentido científico (DOMéNECH et al., 2007, pg. 51, tradução nossa).

Apesar de o caráter sistêmico do conceito científico de energia ser debatido em alguns trabalhos da área de ensino de ciências, a concepção de energia como atributo de um corpo específico ainda é reforçada em livros didáticos e programas educacionais. Mesmo nas pesquisas científicas sobre o ensino de ciências, o caráter sistêmico do conceito de energia costuma ser debatido apenas no que diz respeito às energias potenciais, sobretudo à energia potencial gravitacional, enquanto que pouco se discute sobre isso para o caso da energia cinética. Segundo Doménech et al. (2007):

2 É possível falar de energia de repouso, uma propriedade intrínseca dos corpos, na teoria da relatividade 
Todos os estudos que nós encontramos sobre os equívocos conceituais dos estudantes a respeito do caráter sistêmico da energia se referem às energias potenciais. Nós não encontramos nenhuma referência para considerações similares a respeito da energia cinética. Ao contrário, mesmo nos livros didáticos universitários sempre se referem a energia cinética de um objeto, sem explicar que esta energia expressa a capacidade deste objeto de interagir com outros objetos, por conta de seu movimento com relação a eles com certa velocidade (DOMéNECH et al., 2007, pg. 52 , tradução nossa).

O segundo aspecto que elencamos possui uma estreita relação com o primeiro. É comum que, no ensino básico, se ensine o cálculo de energia - por exemplo cinética ou potencial gravitacional - em um dado referencial e a partir de certas convenções arbitrárias que não são suficientemente esclarecidas. Por exemplo, é muito comum que se convencione que objetos sobre o solo possuam energia potencial gravitacional igual a zero e que objetos em repouso com relação a determinado referencial, normalmente o do observador, possuam energia cinética igual a zero. No entanto, é raro que se reflita sobre a existência desses aspectos convencionais, sobre as vantagens de sua adoção e sobre a possibilidade de se resolver problemas com quaisquer outras convenções. $\mathrm{O}$ ensino de física que traz estas escolhas de forma implícita, tradicionalmente repetidas pela maioria dos materiais didáticos e professores, permite o surgimento da imagem de que os valores de energia calculados são absolutos e representam alguma realidade física dos corpos. Segundo Doménech et al. (2007):

Não há sentido em falar da energia de um sistema em termos absolutos: nós podemos somente determinar suas variações quando um certo processo ocorre. [...] o uso frequente de valores relativos (escolhidos para arbitrariamente atribuir energia zero para uma certa configuração do sistema) pode enganar os estudantes, que tomarão estes valores relativos como absolutos, a menos que insistamos suficientemente sobre o caráter relativo das quantidades usadas. Isto é importante porque o equívoco dos valores absolutos reforça a interpretação da energia como algo possuído pelos objetos por si mesmos (DOMéNECH et al., 2007, pg. 52, tradução nossa).

Se tivermos a intenção de esclarecer o conceito científico de energia de forma que os estudantes não o interpretem como um fluído ou combustível armazenado no interior dos objetos isolados, mas, antes, como uma certa quantidade relacionada à capacidade de transformação dos sistemas, torna-se necessário apresentar o conceito de energia associado às diversas configurações de sistemas possíveis, sistemas que apresentem diferentes tipos de interação entre os objetos que o constituem ou entre si:

Pode-se introduzir várias formas de energia (cinética, gravitacional, potencial, etc.) associadas com várias configurações de sistemas e com diferentes formas de interações. Em outras palavras, a diversidade de qualificações que normalmente acompanham a palavra energia indica a propriedade ou propriedades de sistemas que irão (ou podem) agir em um 
certo processo, ou até o tipo de processo no qual o sistema irá participar. Por exemplo, uma bateria tem energia elétrica porque a separação de cargas elétricas de diferentes sinais nos polos da bateria provê o sistema com a capacidade de produzir transformações quando a circulação de cargas é permitida (DOMéNECH et al., 2007, pg. 51, tradução nossa).

Se o sentido atual do conceito físico de energia está fortemente ligado ao princípio de conservação da energia, ao fato de que a energia é uma quantidade que se mantém constante durante o desenrolar de processos naturais, é fundamental que os alunos tenham domínio sobre as principais técnicas de cálculo da energia nos diferentes tipos de sistemas físicos, a fim de que possam constatar a validade do princípio ou mesmo - aceitando sua validade - inferir sobre aspectos futuros do sistema. Ou seja, os alunos precisam ser capazes de perceber, por exemplo, que enquanto, do ponto de vista mecânico, as velocidades dos corpos diminuíram, do ponto de vista termodinâmico, as temperaturas dos corpos aumentaram. Além disso, precisam enxergar esta diminuição das velocidades e este aumento da temperatura como uma transformação de energia cinética em energia interna ou térmica.

Outra imagem notável do conceito de energia diz respeito a sua definição como capacidade de realizar trabalho em que trabalho é concebido como a grandeza calculada por $\tau=F . d \cdot \cos \theta$. Esta imagem talvez tenha sido impulsionada por Warren em artigo publicado em 1982 e intitulado The nature of Energy. Doménech et al. (2007) afirmam que Warren sugere que os professores não falem sobre energia nas etapas iniciais do ensino, mas, apenas, em etapas mais avançadas em que o conceito deveria ser apresentado baseado no conceito de trabalho. Acontece que com o estabelecimento da Segunda Lei da Termodinâmica ficou claro que nem toda energia pode ser convertida em trabalho e, portanto, continuar apresentando o conceito de energia a partir desta definição deveria ter caído em desuso. No entanto, isso não ocorreu:

\footnotetext{
Sucessivas análises dos livros textos de física têm mostrado que a maioria deles continuam introduzindo o conceito de energia como a capacidade de realizar trabalho, desconsiderando as muitas desvantagens desta definição. Por exemplo, Sexl (1981) sustenta que esta definição não é aplicável à termodinâmica, porque 'a energia interna de um sistema não pode ser completamente transformada em trabalho'. Duit (1986) insiste que esta definição somente é válida na mecânica; portanto, quando os estudantes abordam fenômenos não-mecânicos (por exemplo, reações químicas) eles irão aplicar uma concepção inadequada de energia (DOMéNECH et al., 2007, pg. 49, tradução nossa).
}

Diante das dificuldades de definição para o conceito de energia e os problemas ocasionados por estas definições em seu ensino para estudantes do ensino básico, diversos autores se dividiram quanto às soluções para o problema. Alguns - como Bunge - sugeriram que se deveria introduzir o conceito de energia de uma maneira mais genérica, como a capacidade de realizar mudanças, mas esta definição também foi criticada porque não é a 
variação da energia a responsável pelas mudanças, mas sim a lei de aumento da entropia ${ }^{3}$ (DOMéNECH et al., 2007).

Outros autores - como Feynman - argumentaram que o conceito de energia deveria ser ensinado de um modo estritamente operacional, ou seja, como uma quantidade que pode ser calculada através de diversas expressões matemáticas e que se conserva no decorrer dos processos naturais evitando, assim, quaisquer considerações qualitativas a respeito do conceito de energia (DOMéNECH et al., 2007).

No entanto, Doménech et al. (2007) rejeitam o ensino do conceito de energia de uma forma puramente operacional apresentando, para isso, 3 razões:

\begin{abstract}
Em nossa opinião, esta introdução meramente operacional é inadequada por diversas razões. Primeiro, isto não previne a formação de visões qualitativas distorcidas, ou a persistência de concepções ingênuas adquiridas por impregnação do meio, independentemente ou por qualquer educação formal (Gil-Pérez et al.2002). Segundo, os estudantes precisam saber que os cientistas pensam qualitativamente: antes de começar a fazer cálculos, eles já possuem o curso de seus raciocínios em suas mentes. Isto, na maioria dos casos, pode ser expresso em palavras simples. Cálculos e fórmulas são a próxima etapa. [...] Finalmente, nós enfatizamos que as considerações qualitativas iniciais sobre energia não devem ser julgadas à luz do corpo de conhecimento aceito atualmente (depois de muito desenvolvimento), mas à luz de suas capacidades de facilitar o processo de construção, durante o qual as ideias iniciais envolverão concepções mais elaboradas e frutíferas (DOMéNECH et al., 2007, pg. 50, tradução nossa).
\end{abstract}

Acreditamos que, com o trecho acima, os autores não tivessem a intenção de definir critérios exatos para a distinção entre pensar qualitativamente e fazer cálculos, como se antes se raciocinasse e, apenas, depois se fizessem os cálculos. Como vimos, calcular e aplicar conceitos são atividades que se relacionam mutuamente na constituição de uma práxis científica. Interpretamos que a intenção dos autores tenha sido a de enfatizar a importância do pensamento especulativo antes de definir precisamente os conceitos, de forma que a definição escolhida seja frutífera para o desenvolvimento da investigação científica.

Sobre as considerações qualitativas que levam os físicos a formularem conceitos com definições matemáticas, operacionais, temos o próprio caso do conceito de trabalho. Doménech et al. (2007) afirmam que Maxwell chegou a propor uma concepção de trabalho mais abrangente que o produto entre a força e a distância:

Qualitativamente o trabalho deve ser concebido como o ato de transformar a matéria por meio da aplicação de forças. Esta é a concepção proposta

3 Enquanto o conceito de energia permite avaliar os possíveis cenários futuros de um sistema físico a partir de uma avaliação energética é a lei da entropia que explica porque essas mudanças ocorrem de fato. 
por Maxwell (1877) e reflete a ideia de trabalho de nosso cotidiano: qualquer exemplo elementar do que é considerado trabalho (cavar a terra, suspender objetos pesados, etc.) aparece como um processo de transformação de matéria pela aplicação de forças. A definição operacional de trabalho como o produto da força pela distância corresponde com esta ideia qualitativa para o caso mais simples de um objeto que é movido (DOMéNECH et al., 2007, pg. 53, tradução nossa).

É interessante notar que o conceito operacional de trabalho, definido através do produto da força pela distância, contemple apenas um dos aspectos do conceito qualitativo proposto por Maxwell. Ainda que esta definição operacional dê conta de explicar os fenômenos tipicamente abordados pela mecânica, nos chama a atenção como, de fato, trata-se de uma concepção mais restrita que àquela que lhe deu origem.

Aproximando-nos das considerações de Doménech et al. (2007) a respeito do ensino do conceito de energia, acreditamos que estas reflexões sobre aspectos qualitativos do conceito de energia - e demais conceitos a ele associados - registradas na história das ciências podem ser interessantes para mostrar aos estudantes que as definições dos conceitos se estabelecem em função do conjunto de problemas que a comunidade científica pretende solucionar. Além disso, ter conhecimento das reflexões teóricas que precederam a definição dos conceitos presentes nas grandes teorias das ciências pode fornecer recursos para que se escape de possíveis aplicações dogmáticas dos conceitos realizadas na produção de conhecimento científico ou nos diversos níveis do ensino de ciências. Segundo Doménech et al. (2007):

\footnotetext{
É essencial prestar atenção ao significado destes conceitos [trabalho, calor e energia], evitando o tratamento puramente operacional. Não se pode, por exemplo, definir trabalho somente como o produto da força pela distância. Esta abordagem pode favorecer uma visão dogmática de ciência que distorce seu caráter tentativo: conceitos são invenções hipotéticas que tem suas origens em considerações qualitativas (DOMéNECH et al., 2007, pg. 52, tradução nossa).
}

A compreensão dos alunos a respeito do conceito físico de calor também apresenta dificuldades. Entre elas estão a confusão entre calor e temperatura, a concepção de calor como um fluído (teoria do calórico) e a interpretação do calor como um tipo de energia (DOMéNECH et al., 2007). A principal consequência destas dificuldades é que representam obstáculos à compreensão das relações entre termodinâmica e mecânica e, consequentemente, à formulação do princípio de conservação da energia.

É comum, mesmo nas aulas de física, escutar afirmações como "Devido ao processo de frenagem, a energia cinética do carro se transforma em calor nas rodas, nos discos de freios ou no asfalto". No entanto, afirmações como estas fazem um uso do termo calor seguindo regras típicas da gramática dos tipos de energia quando, já é estabelecido entre os físicos, que o calor - assim como o trabalho - corresponde à um processo de troca de 
energia entre as partículas de um sistema e sua vizinhança. Segundo Doménech et al. (2007):

Estas e outras dificuldades [extração sem fim do calórico contido em um objeto], levou-nos à hipótese de equivalência entre o calor Q e o trabalho W, levando em consideração as interações microscópicas que ocorrem em um sistema, especificamente, aceitando a concepção corpuscular da natureza da matéria. Como Alonso e Finn (1969, capítulo 9) explicam, 'Q é composto por uma soma muito numerosa de trabalhos externos individuais muito pequenos, de tal forma que não podem ser expressos coletivamente como uma média de produtos de forças por distâncias' (p. 263). O conceito de 'energia interna' pode ser introduzido de forma parecida. [...] calor, como trabalho microscópico, não é uma forma de energia mas antes um mecanismo de troca de energia entre as partículas do sistema e suas vizinhanças (DOMéNECH et al., 2007, pg. 54, tradução nossa).

Concebendo calor e trabalho como processos de troca de energia entre elementos de um sistema físico ou entre diferentes sistemas físicos dentro de uma teoria corpuscular da matéria se possibilitou os progressos científicos alcançados pelos proponentes do princípio de conservação da energia (DOMéNECH et al., 2007). Segundo Doménech et al. (2007):

Estes avanços levaram à integração da mecânica e da termodinâmica, duas áreas da ciência que se desenvolviam autonomamente e pareciam não ter nada em comum. Esta integração, associada com os trabalhos de Carnot, Rumford, Joule, Thomson, Mayer, etc., tornou possível o estabelecimento da lei de conservação da energia e melhor explicou as causas das transformações (DOMéNECH et al., 2007, pg. 55, tradução nossa).

O processo de integração entre mecânica e termodinâmica através da aproximação entre os conceitos de trabalho e calor dentro de uma teoria corpuscular da matéria representou uma revolução teórica muito profunda. Fizeram parte desta revolução, dentre outras coisas, o triunfo da concepção corpuscular da matéria sobre a concepção da substância contínua, a consolidação dos princípios da mecânica estatística como fundamento da termodinâmica e o abandono da teoria do calórico na termodinâmica. Segundo Doménech et al. (2007):

É necessário ressaltar a busca por generalidade e coerência global como características do empreendimento científico, as quais permitem a integração de campos aparentemente desconectados. Os estudantes devem entender particularmente que a integração da mecânica com a termodinâmica foi uma profunda revolução científica, que possibilitou compreender a natureza do calor e o estabelecimento do princípio de conservação e transformação da energia (DOMéNECH et al., 2007, pg. 48, tradução nossa).

Neste ponto, nos aproximamos da última concepção problemática de energia que decidimos elencar neste trabalho, a saber, a concepção de que o princípio de conservação 
da energia possa ser derivado das leis da dinâmica, da conservação da energia mecânica. Como vimos, o estabelecimento do princípio de conservação da energia só se deu a partir da compreensão das relações entre fenômenos macroscópicos (mecânica) e fenômenos microscópicos (termodinâmica), relação expressa - por exemplo - na formulação da primeira lei da termodinâmica $W+Q=\Delta E$, onde $\mathrm{W}$ representa o trabalho realizado por forças externas ao sistema e Q engloba os trabalhos microscópicos que ocorrem quando o sistema está em contato com vizinhanças à diferentes temperaturas (DOMéNECH et al., 2007). Segundo Doménech et al. (2007), a primeira lei da termodinâmica afirma implicitamente que as mudanças possíveis em um sistema isolado são aquelas que mantêm a energia do mesmo constante:

\begin{abstract}
As mudanças que ocorrem em um sistema podem envolver a transformação de alguns tipos de energias em outras formas de energia (por exemplo, potencial gravitacional em cinética), ou a transferência de energia de alguns sistemas para outros sistemas, o de algumas partes de um sistema para outras partes do mesmo sistema (como acontece quando objetos à diferentes temperaturas são colocados em contato entre si). Entretanto, há uma restrição para as possíveis transformações. Somente mudanças em propriedades que fazem a energia total de um sistema isolado (incluindo a energia interna) permanecer constante podem ocorrer (DOMéNECH et al., 2007, pg. 56, tradução nossa).
\end{abstract}

Considerando os processos que envolvem transformações ou trocas de energia relacionadas aos níveis macroscópicos e microscópicos, concluímos que o princípio de conservação da energia não pode ser apresentado a partir do caso da conservação da energia mecânica, visto que não é possível derivar este princípio das leis da dinâmica. Segundo Doménech et al. (2007):

De modo algum, pois, pode-se aceitar as tentativas de apresentar o princípio de conservação da energia como uma generalização das relações entre trabalho e energia estabelecidas na mecânica (DOMéNECH et al., 2001, pg. 49, tradução nossa).

Apesar de a expressão $W+Q=\Delta E$ relacionar os fenômenos macroscópicos e microscópicos em uma equação que apresenta certo princípio de conservação, também não podemos considerar que esta seja uma expressão geral da conservação da energia, uma vez que nem toda troca de energia ocorre por processos mecânicos ou termodinâmicos. Doménech et al. (2007):

As variações de energia podem ocorrer, não somente através de trabalho e calor, mas também por meio de processos, como a troca por radiação (Chabay e Sherwood 1999, p.149). Surpreendentemente, este aspecto é raramente contemplado nos cursos do ensino médio e na pesquisa em ensino de ciências. Apesar de concordarmos que o estudo da radiação, como mecanismo de transferência de energia, não deva ser completamente desenvolvido neste nível, dada sua complexidade, é absolutamente 
necessário fazer referências qualitativas para este processo. Não podemos esquecer que a maioria dos recursos energéticos disponíveis na Terra (incluindo combustíveis fósseis) têm sua origem na radiação solar; também não pode ser ignorado que a compreensão do efeito estufa não é possível sem referências à trocas de energia por radiação (DOMéNECH et al., 2007, pg. 56, tradução nossa).

Como vimos, o princípio de conservação da energia somente pôde ser compreendido a partir de teoria capaz de relacionar fenômenos termodinâmicos e mecânicos através de uma aproximação dos conceitos de trabalho e calor, respectivamente, como processos de transferência de energia nos domínios macroscópico e microscópico. Por isso, acreditamos que a apresentação deste princípio como uma generalização da conservação da energia mecânica seja inapropriada. Uma apresentação deste princípio que leve em consideração a revolução representada pelo estabelecimento das relações entre estes dois campos da física seria muito mais desejável, mas, mesmo assim, não seria suficiente para dar conta de todos os tipos de processos de troca de energia possíveis. Deve-se, ainda, ao menos fazer referências qualitativas à processos de trocas de energia por meio de radiação com a finalidade de proporcionar ferramental suficiente para que os estudantes compreendam processos como, por exemplo, o efeito estufa.

Outro aspecto que precisa ser considerado é que apesar de a energia interna de um sistema - aquela correspondente à energia cinética e potencial das moléculas constituintes de um corpo - poder ser descrita por uma mecânica estatística, esta não é totalmente equivalente à energia mecânica:

Ainda que o princípio de conservação e transformação da energia esta-
beleça que algumas formas de energia podem se transformar em outras,
a energia mecânica (macroscópica) e a energia interna não são to-
talmente equivalentes, visto que enquanto em um sistema isolado é
possível transformar integralmente a energia mecânica em energia interna,
o processo recíproco não é possível, posto que suporia a transformação
do movimento desordenado de uma infinidade de partículas em um
movimento ordenado (DOMéNECH et al., 2001, pg.49, tradução nossa).

Considerando tudo o que foi exposto sobre o princípio de conservação da energia, poderíamos, ingenuamente, concluir que: se a energia de um sistema isolado permanece constante, não há razão para atribuir à energia o status de causa das mudanças que ocorrem em um sistema. No entanto, por trás da energia constante de um sistema podem haver mudanças que não alterem a quantidade de energia de um sistema. Segundo Doménech et al. (2007):

Apesar de a energia total de um sistema isolado permanecer constante, sempre que um sistema experiencia uma mudança irreversivel ocorrem transferências e/ou transformações de energia em seu interior. Expressões como $E=$ constante ou $\Delta E=0$ parecem indicar que a energia não está relacionada com as transformações, mas $\Delta E=0$ engloba uma série de 
variações de energia que precisam ser explicitadas: $\Delta E_{k}+\Delta \mathrm{E}_{\mathrm{p} \text { gravitacional }}$ $+\Delta \mathrm{E}_{\mathrm{p} \text { eletrica }}+\ldots=0$. Isto justifica a comum associação entre energia e mudança, apesar de que esta associação não explica em si quais sequências de mudanças são possíveis e quais não; isto indica que precisamos prestar atenção à 'degradação' da energia que acompanha quaisquer processos (DOMéNECH et al., 2007, pg. 57, tradução nossa).

A energia de um sistema isolado apenas oferece as condições de possibilidade dos estados que tal sistema pode vir a assumir por meio de interações entre suas partes ou com outros sistemas. Resta-nos então a questão qual a causa das mudanças que ocorrem nos sistemas? A degradação da energia. Sobre a pouca atenção dedicada a degradação da energia nos cursos de física Duit (1986):

\footnotetext{
Nenhum outro aspecto no ensino de física é tratado com tanta desproporção com relação à sua significância. Sem o aspecto da degradação da energia, a compreensão do conceito físico de energia é incompleta; sem isso o conceito de energia deverá falhar quando aplicado à natureza, à tecnologia e no cotidiano (DUIT, 1986, pg. 89, tradução nossa).
}

O aspecto da degradação da energia, correspondente à segunda lei da termodinâmica, é que explica quais sequências de mudanças podem ou não ocorrer no interior de sistemas isolados além de serem a razão pela qual estes processos ocorrem. Segundo Doménech et al. (2007):

\begin{abstract}
Como um resultado de interações e consequentes transformações de um sistema, a energia se degrada ou, em outras palavras, é distribuída mais homogeneamente. Em outras palavras, sistemas isolados evoluem para estados mais desordenados, que apresentam maior probabilidade de ocorrência: as diversas partículas em um sistema apresentam maior probabilidade em moverem-se aleatoriamente do que de forma ordenada. Esta evolução para configurações mais desordenadas reduz a possibilidade de futuras transformações do sistema (DOMéNECH et al., 2007, pg. 57, tradução nossa).
\end{abstract}

É interessante reconhecer, nesta formulação a respeito da segunda lei da termodinâmica, as influências da física de Ludwig Boltzmann (apresentada no capítulo 2) com sua metodologia de descrição dos estados possíveis que um sistema mecânico estatístico poderia assumir e posterior estudo dos estados encontrados com maior frequência na natureza.

A segunda lei da termodinâmica estabelece que, ao passo que a energia total de um sistema isolado permanece constante, a energia de um sistema isolado tende a se distribuir por suas partes até que alcance a configuração mais homogênea possível que corresponderia à partículas livres em movimento aleatório, configuração chamada de morte térmica do universo para o caso em que o sistema em questão é o universo. 
Apesar de a degradação da energia, ou lei da entropia ${ }^{4}$, estar fundamentada em uma mecânica estatística cujo tratamento matemático apresenta alto nível de complexidade, pode-se aludir à esta lei de uma maneira qualitativa com os estudantes de forma bastante simples e intuitiva. Segundo Doménech et al. (2007):

Estas ideias podem ser compreendidas pelos estudantes sem muitas dificuldades: eles compreendem, por exemplo, que é fácil transformar toda a energia cinética de um sistema em energia interna (por exemplo, quando um carro para), enquanto o processo recíproco é muito menos eficiente, porque é muito improvável transformar completamente a agitação aleatória de um grande número de partículas que converteriam um sistema em um movimento sincronizado de todas elas na mesma direção (DOMéNECH et al., 2007, pg. 57).

Apenas um conceito de energia que inclua os fatores acima citados possibilitarão a compreensão do princípio de conservação da energia em todo seu significado sem, por exemplo, causar confusões com termos como crise energética, falta de energia e produção de energia. $\mathrm{O}$ fato de dizermos que, como sociedade, enfrentamos uma crise energética não significa, porém, que a energia está desaparecendo, sendo completamente consumidas por nossas atividades, o que seria incoerente com o princípio de conservação da energia. Segundo Doménech et al. (2007):

Expressões como 'consumo de energia' ou 'crise energética', não significam, que a energia desaparece mas que torna-se menos útil (a nova configuração do sistema não facilita que outras mudanças ocorram). Portanto, a aparente contradição entre 'conservação da energia' e a 'necessidade' de recursos energéticos', desaparece (Duit 1986; Ogborn 1990).

O processo de distribuição de energia (ou aumento da entropia) de um sistema reduz a probabilidade de ocorram futuras transformações macroscópicas no sistema. É necessário insistir neste ponto (que não tem sido abordado na literatura sobre ensino de ciências) porque as interações (e portanto, as transformações) continuam ocorrendo no nível microscópico. Entretanto, o que é realmente pouco provável (ainda que não impossível) é que transformações macroscópicas ocorram de forma a levar o sistema para configurações mais 'ordenadas' (DOMéNECH et al., 2007, pg. 58, tradução nossa).

Em síntese, duas são as condições para que um sistema isolado experimente mudanças. Primeiro, as transformações de energia e/ou transferências de energia entre partes de um sistema precisam necessariamente satisfazer o princípio de conservação da energia, ou seja, somente mudanças que levem o sistema para configurações de mesma quantidade de energia podem ocorrer. Segundo, a energia de um sistema isolado não pode, inicialmente, estar uniformemente distribuída. Os sistemas evoluem para configurações

4 Com a finalidade de representar essa lei, foi criada uma nova grandeza, a entropia S, que representa a desordem de um sistema. Esta grandeza foi definida de tal forma que seu valor aumenta a cada processo irreversível que ocorre num sistema. 
mais uniformes (aumenta a entropia $\mathrm{S}$ ) ainda que a entropia de algumas de suas partes possam diminuir, ou seja, ainda que o grau de organização de algumas de suas partes possa aumentar (DOMéNECH et al., 2007). Segundo Doménech et al. (2007):

É verdade que em muitos sistemas abertos (tais como os seres vivos) a entropia decresce (sistemas se tornam mais ordenados), mas a entropia total de um sistema isolado formado por estes seres vivos e suas vizinhanças aumenta (DOMéNECH et al., 2007, pg. 58, tradução nossa).

Em sua obra $O$ que é vida?, Erwin Schrödinger reflete sobre a capacidade que os seres vivos têm de, além de evitar a redução de sua organização, aumentar seus níveis de organização em determinado período de suas vidas. Segundo Schrödinger (1997):

\footnotetext{
Quando um sistema não vivo é isolado ou colocado em um ambiente uniforme, usualmente todo o movimento cessa depressa, como resultado de vários tipos de fricção; diferenças de potencial químico ou elétrico são equalizadas, substâncias que tendem a formar compostos químicos o fazem e a temperatura se torna uniforme por condução térmica. Depois disso, todo o sistema míngua para um bloco inerte e morto de matéria. É atingido um estado permanente, no qual não ocorre nenhum evento observável. O físico dá a esse estado o nome de equilíbrio termodinâmico ou estado de "entropia máxima" [...] É por evitar o rápido decaimento no estado inerte de "equilíbrio" que um organismo parece tão enigmático [...] Como um organismo vivo evita o decaimento? A resposta óbvia é: comendo, bebendo, respirando e (no caso das plantas) assimilando. O termo técnico é metabolismo. A palavra grega $(\mu \varepsilon \tau \alpha \beta \alpha \lambda \lambda \varepsilon \iota \nu)$ quer dizer troca ou câmbio. [...] Só pode [o ser vivo] se manter distante disso [do estado de entropia máxima], isto é, vivo, através de um processo contínuo de extrair entropia negativa do ambiente. [...] Um organismo se alimenta, na verdade, de entropia negativa. Ou, exprimindo o mesmo de modo menos paradoxal, o essencial no metabolismo é que o organismo tenha sucesso em se livrar de toda e entropia que ele não pode deixar de produzir por estar vivo (SCHRöDINGER, 1997, pg. 83).
}

Para manter-se vivo, um organismo precisa obter energia a partir da metabolização da organização existente em fatores extrínsecos a si e ser capaz de expelir o produto desorganizado deste processo de metabolização. Assim, na medida em que realiza a manutenção de sua organização interna um organismo vivo colabora com a desorganização de sua vizinhança, isto é, ajuda na evolução de seu ambiente para configurações mais homogêneas que a que se encontra.

Outro exemplo de diminuição local da entropia que, simultaneamente, causa um aumento global de entropia seria o sistema Terra-Sol no qual a energia produzida pelo consumo de matéria no interior do Sol proporciona o desenvolvimento dos atributos geológicos, vegetação e seres vivos do planeta Terra. Na medida em que estruturas se organizam no planeta Terra, diminuindo sua entropia, o sistema Terra-Sol se aproxima cada vez mais do equilíbrio termodinâmico. 
Os aspectos do conceito de energia que apresentamos nesta seção serão utilizados como referência para as análises que se seguem.

\subsection{Considerações sobre duas coleções de livros didáticos do PNLD 2015}

As coleções selecionadas para a análise foram FÍSICA: CONCEITOS E CONTEXTOS Pessoal, Social e Histórico (PIETROCOLA et al., 2013) e a coleção Quanta Física (KANTOR et al., 2013). Ambas as coleções foram aprovadas pelo Programa Nacional do Livro Didático para o Ensino Médio (PNLDEM) de $2015^{5}$ e, apesar de não terem sido adotadas durante as aulas que observamos, foram escolhidas por terem sido concebidas por membros ativos da comunidade de pesquisa em ensino de ciências e, portanto, constituindose como exemplos de transposições didáticas em relativa consonância com as mais recentes pesquisas.

Foram selecionados os capítulos dedicados ao tema energia em cada uma das coleções. Na coleção Física: Conceitos e Contextos os capítulos selecionados foram 1, 2, 3, 4, 5, e 9 do volume 2 enquanto na coleção Quanta Física os capítulos selecionados foram 1, 2, 3, 4 e 5 da unidade 1 do volume 1 e o capítulo 3 da unidade 2 do volume 1 .

A análise da apresentação do conceito de energia, nos livros didáticos selecionados, foi realizada em diferentes níveis. Em um primeiro nível, procurou-se compreender em que ordem e dentro de que temáticas cada coleção escolheu trabalhar com o conceito de energia. Para isso, foi necessário estudar o número de ocorrências do termo energia em cada capítulo, identificando a temática na qual tais usos foram realizados.

Consideramos todas as ocorrências do termo energia nos capítulos mencionados, incluindo as expressas por meio de variáveis em equações e as encontradas nas legendas de imagens e tabelas. No entanto, foram desconsideradas as repetidas ocorrências nos cabeçalhos e rodapés das páginas.

Um gráfico foi produzido através da tabulação do número de ocorrências do termo energia por página. Foram destacados intervalos com alta ocorrência do termo e, em seguida, foram identificados os temas relacionados com cada intervalo:

5 Os dados e as análises apresentadas nesta seção foram apresentados em uma monografia, pelo mesmo autor desta dissertação e sob orientação da Dra. Cristiane Gottschalk, ao final da graduação. Consideramos a inclusão destas análises na dissertação pertinente porque o desenvolvimento da monografia nos conduziu ao problema de pesquisa abordado neste trabalho e porque este trabalho se mostrou uma fecunda oportunidade para o aprofundamento das discussões apresentadas na monografia. As monografias, no entanto, não são publicadas. 
Gráfico 1 - Uso do conceito de energia nas duas coleções de livros didáticos
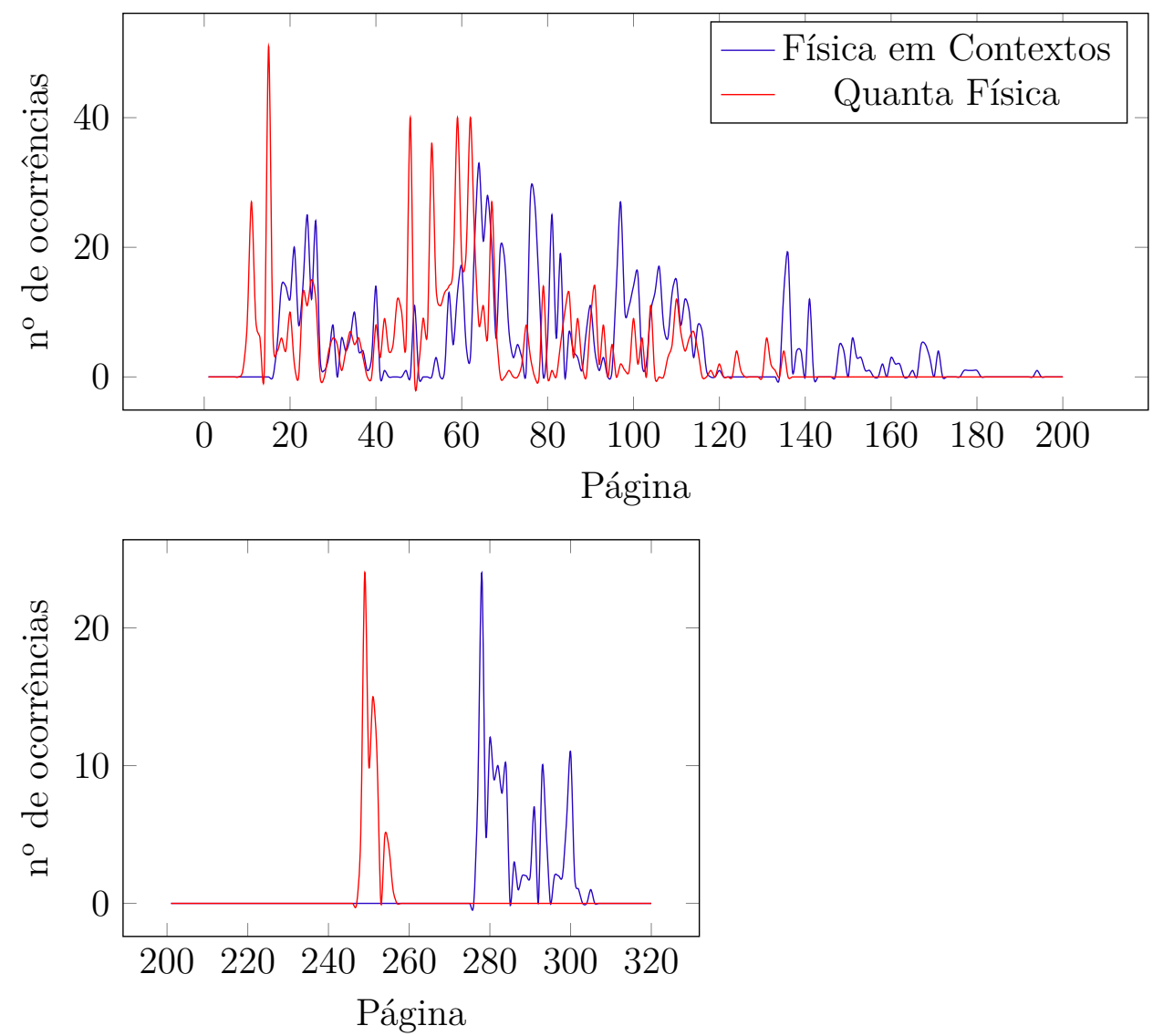

Tabela 1 - Páginas e $\mathrm{n}^{\mathrm{O}}$ de ocorrências do termo energia por temática

\begin{tabular}{c|c|c} 
Temáticas & Física em Contextos & Quanta Física \\
\hline A & 16 até $56(231$ vezes $)$ & 6 até $50(284$ vezes $)$ \\
B & 57 até $96(409$ vezes $)$ & 51 até $66(326$ vezes $)$ \\
C & 162 até 196 e 280 até $306(172$ vezes $)$ & 67 até 93 (131 vezes) \\
D & Não apresenta & 93 até 137 (114 vezes $)$ \\
E & 97 até $117(227$ vezes $)$ & Não apresenta \\
F & 118 até $161(82$ vezes $)$ & 246 até $258(75$ vezes $)$ \\
\hline Total & 1121 vezes & 930 vezes
\end{tabular}

\footnotetext{
A - Introdução à energia, contextualização e transformações de energia

B - Energia mecânica, Sistemas conservativos e não conservativos

C - Energia como calor e leis da termodinâmica

D - Energia potencial química e consumo doméstico de energia elétrica

E - Tipos e transformações de energia

F - Conservação da energia cinética nas colisões
}

Destacamos que o termo energia apresenta maior número de ocorrências na temática $\mathrm{B}$, relativa à energia mecânica, nas duas coleções. Consultando a Tabela 1, obtemos 409 
ocorrências na coleção Física em contextos e 326 ocorrências na coleção Quanta física. Quando comparamos estes valores com o número total de ocorrências nos capítulos selecionados, verificamos que representam cerca de $36 \%$ dos usos do termo energia. Essa porcentagem revela a escolha dos autores em privilegiar a mecânica como temática mais relevante para o ensino do conceito de energia, visto que uma distribuição homogênea dos usos do conceito de energia seria de $20 \%$ para cada uma das temática.

Além das numerosas ocorrências do termo energia na temática relativa a energia mecânica, há outra escolha dos autores que indica que a mecânica é uma área privilegiada no ensino do conceito, a saber, o fato de que o princípio de conservação da energia - que envolve todos os tipos de energia e processos de conversão de energia - é apresentado na mesma unidade em que é apresentada a conservação da energia mecânica.

Em um segundo nível de análise, cada uso do conceito de energia foi classificado segundo o aspecto do conceito de energia sobre a qual estava alicerçado. Neste nível, as contagens dos aspectos do conceito de energia por capítulo foram tabuladas e, em seguida, construiu-se um gráfico:

Gráfico 2 - Aspectos do conceito de energia nas coleções de livros didáticos
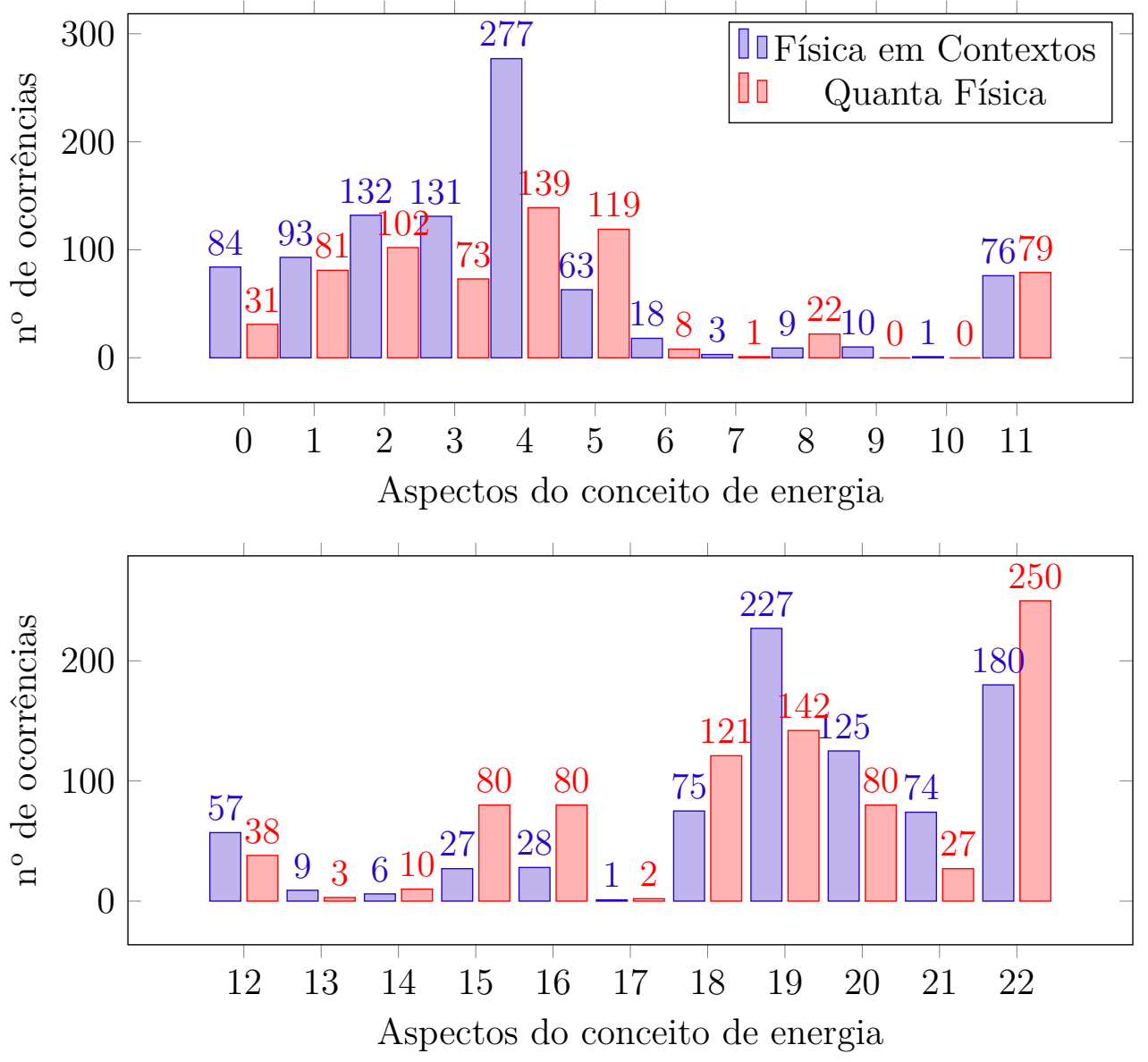

As categorias utilizadas para a elaboração do gráfico 2 são apresentadas a seguir:

0 - Referência ao próprio conceito

1 - A energia pode ser obtida através de determinados processos 


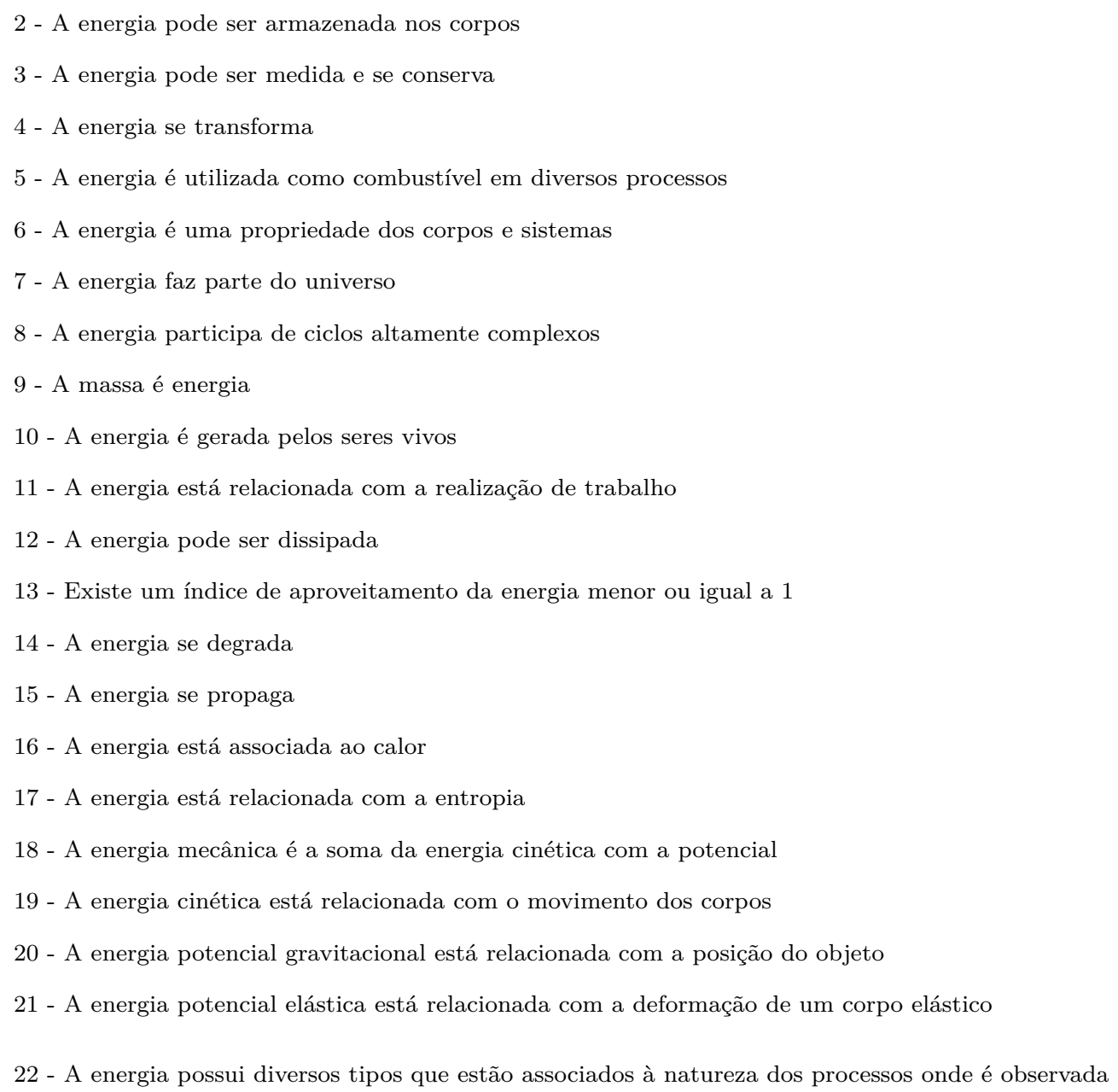

Os 3 aspectos do conceito de energia mais ressaltados em ambas as coleções são os de número 4, 19 e 22 com uma pequena inversão de ordem em cada uma das coleções. A principal ideia transmitida pelo conjunto desses três aspectos do conceito é a de que a energia é algo que possui diversos tipos, sofre transformações de um tipo para o outro e está relacionada com o movimento. Destacamos que a desproporcional associação entre energia e movimento, já constatada como frequente pela literatura como em (BARBOSA; BORGES, 2006) e (ASSIS; TEIXEIRA, 2003), também é verificada nas coleções analisadas.

Os aspectos do conceito de energia com menor frequência em ambas as coleções são os de número 7, 10 e 17 com uma pequena inversão de ordem em cada uma das coleções. A principal ideia transmitida pelo conjunto desses aspectos do conceito é a de que a energia está relacionada, tendo o conceito de entropia como mediador, com a organização de sistemas complexos tais como o universo, os ecossistemas e os seres vivos.

Outros itens, também relacionados com o caráter sistêmico do conceito de energia, apresentam número de ocorrências relativamente baixos quando comparados à outros aspectos, são eles: a energia como propriedade dos sistemas (6) e a degradação da energia (14).

Se pretendemos preparar os estudantes para enfrentarem os problemas emergentes 
do mundo contemporâneo como, por exemplo, a crise energética, os impactos ambientais da vida urbana e o aquecimento global, precisamos fornecer ferramentas mínimas para que os mesmos consigam avaliar problemas complexos. O conceito de energia pode ser uma ferramenta útil na análise destes tipos de fenômenos e problemas (DOMéNECH et al., 2007).

A categoria número 22, A energia possui diversos tipos que estão associados à natureza dos processos onde é observada, foi analisada com mais especificidade e, o seguinte gráfico foi elaborado com os dados obtidos:

Gráfico 3 - Tipos de energia nas coleções de livros didáticos

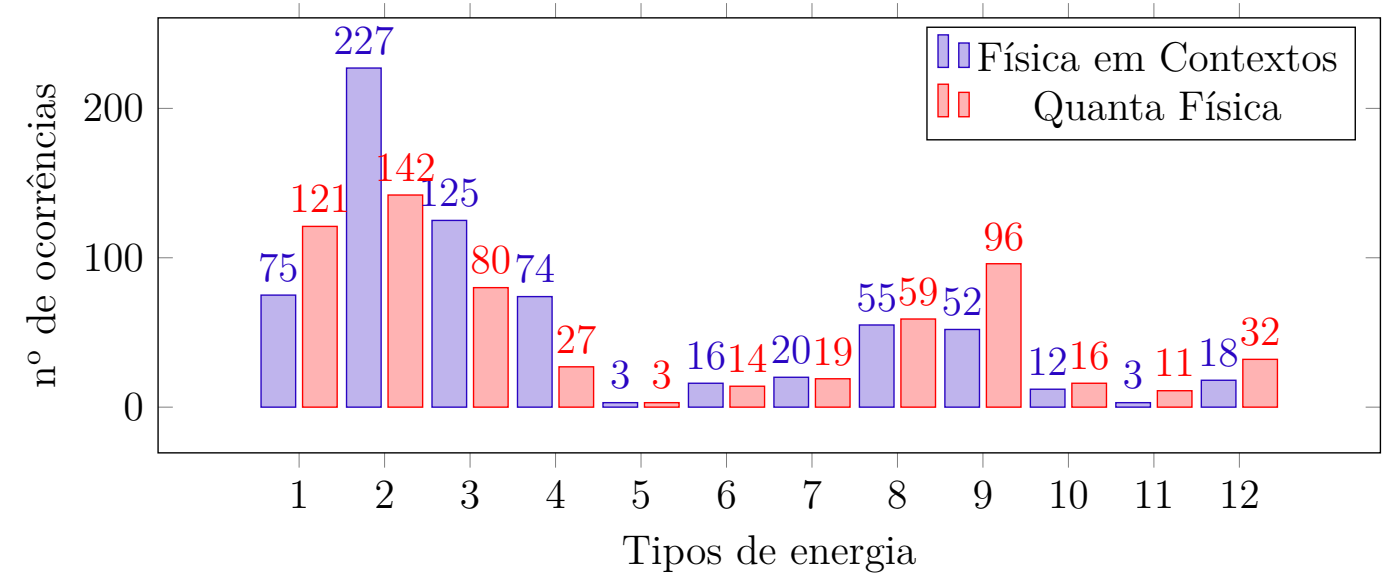

$$
\begin{aligned}
& 1 \text { - Mecânica } \\
& 2 \text { - Cinética } \\
& 3 \text { - Gravitacional } \\
& 4 \text { - Elástica } \\
& 5 \text { - Sonora } \\
& 6 \text { - Luminosa } \\
& 7 \text { - Química } \\
& 8 \text { - Térmica } \\
& 9 \text { - Elétrica } \\
& 10 \text { - Nuclear } \\
& 11 \text { - Eólica } \\
& 12 \text { - Solar }
\end{aligned}
$$

Em ambas as coleções o tipo de energia mais frequentemente mencionado foi a energia cinética, relacionada ao movimento dos corpos materiais. Na coleção Fúsica em contextos, as ocorrências para energia cinética representam cerca de $33 \%$ do total das ocorrências de tipos de energia e na coleção Quanta Física este índice é aproximadamente $23 \%$. Estes valores expressam a alta frequência com que o conceito de energia é associado ao movimento, visto que uma distribuição homogênea resultaria em índices próximos de $8 \%$ para cada tipo de energia. 
Além disso, as coleções apresentam diferentes tipos de energias como segundo e terceiro colocados no que diz respeito ao número de ocorrências. A coleção Física em contextos apresenta as energias gravitacional e mecânica enquanto a coleção Quanta física apresenta as energias mecânica e elétrica. Novamente, os tipos de energias mais frequentemente reconhecidos pelos alunos são aqui representados com maiores frequências, a saber, cinética e elétrica. Já os tipos de energia com menor frequência em ambas as coleções são sonora, eólica e luminosa.

\subsection{Observação das aulas de física em uma escola estadual}

Observamos as aulas de física de uma turma de $2^{\circ}$ ano do ensino médio de uma escola estadual de São Paulo com a finalidade de analisar o ensino do conceito de energia de maneira mais detalhada. Além de fornecer mais detalhes sobre o processo de ensino do conceito de energia, a análise das observações em sala de aula serviram para corroborar ou fornecer contrapontos às informações encontradas na literatura e extraídas da análise das coleções de livros didáticos sobre o ensino do conceito de energia.

O motivo de escolhermos o segundo ano do ensino médio para coletar nossos dados se deve ao fato de que os livros didáticos, em sua maioria, preveem uma ênfase no ensino do conceito de energia neste ano através de tópicos como tipos de energia, transformações de energia, matrizes energéticas e termodinâmica.

Comunicamos o tema da pesquisa para o professor que nos acolheu na escola já durante o período de negociação do processo de observação. Durante este primeiro contato, foi destacado que não pretendíamos interferir em seu planejamento e que pretendíamos avaliar de que maneira o conceito de energia estava presente nos conteúdos abordados durante o ano, seja explícita ou implicitamente. Mesmo assim, o professor mencionou que não havia dado tempo de trabalhar o conceito de trabalho e energia com a turma no ano anterior, quando também eram seus alunos de física, e que decidira ensinar estes conceitos durante o $2^{\circ}$ ano para, então, abordar o conceito de energia na termodinâmica.

Esta escolha, por parte do professor, apresenta uma relevância significativa para nossa investigação, visto que o mesmo considerou necessário ensinar o conceito de energia no contexto da mecânica antes de ensiná-lo no contexto da termodinâmica como se concebesse que um é pré-requisito do outro. Tal fato parece corroborar nossa hipótese de que uma concepção de energia proveniente do campo da mecânica é privilegiada no ensino de física ou que o conceito de trabalho e energia do contexto da mecânica sejam usados como fundamentos da análise dos fenômenos da termodinâmica. 


\subsubsection{O conceito de energia no material adotado pelo professor}

Nesta seção faremos uma análise da concepção de energia presente na apostila utilizada pelo professor como material de apoio para as aulas de física durante o $1^{\circ}$ semestre de 2017. Trata-se de uma apostila desenvolvida pelo professor Ronald Wykrota e disponível para acesso pela internet. A apostila foi desenvolvida para ser usada como material de apoio das disciplinas de física básica da modalidade de Ensino de Jovens e Adultos (EJA) do Centro Estadual de Educação Profissional de Curitiba (CEEP Curitiba).

A apostila está organizada em dois volumes com diversas aulas que abordam temas da mecânica, hidráulica, ótica geométrica, ondulatória, eletromagnetismo e física moderna. O professor da turma que acompanhamos utilizou as aulas de 20 à 29 do primeiro volume da apostila durante o período em que realizamos nossas observações.

O início do texto relativo à aula 20 reconhece diversas possibilidades de definição do conceito de energia e atribui esta característica ao fato de que a energia não pode ser tocada com a mão ou observada com os olhos. Segundo Wykrota (2012):

O conceito de energia pode ser considerado intuitivo, pois cada um de nós pode enunciar este conceito de maneiras muito diferentes, porém corretas. Isso acontece, pois não podemos tocar com as mãos ou visualizar a energia. Sabemos que ela existe devido aos seus efeitos que podem ser visualizados com facilidade (WYKROTA, 2012, pg. 21).

É interessante notar que o autor admite a possibilidade de que o conceito de energia seja enunciado de diversas maneiras diferentes entre si. Tal afirmação está de acordo com a concepção de linguagem do segundo Wittgenstein que afirma que, geralmente, os conceitos são vagos e esta vagueza dos conceitos não atrapalha, de forma alguma, seu emprego no cotidiano (WITTGENSTEIN, 2000, § 68). Chamamos a atenção, no entanto, para o emprego do termo existe na afirmação presente no final da citação "Sabemos que ela existe devido aos seus efeitos...". Tal emprego pode conduzir os estudantes e professores a pensarem que a energia possua uma existência material, no sentido de que seja algo que se encontre em algum lugar dos corpos. Claramente, interpretações desta natureza podem ocorrer devido à força da imagem agostiniana da linguagem, já mencionada em capítulos anteriores. Não queremos dizer, com isso, que o autor do texto acredite que a energia seja algo como uma substância que se encontra em algum lugar mas, antes, que a aparência uniforme das palavras quando empregadas nas mais diversas proposições podem nos conduzir a este tipo de interpretação se não esclarecemos o sentido de seu emprego. Segundo Wittgenstein (2000):

... o que nos confunde é a uniformidade da aparência, quando estas nos são ditas, ou quando com elas nos defrontamos na escrita e na imprensa. Pois seu emprego não nos é tão claro. E especialmente não o é quando filosofamos! (WITTGENSTEIN, 2000, § 11). 
Em seguida, o texto associa o conceito de energia ao princípio de Lavoisier e ao conceito de trabalho dizendo que este último permite medir a quantidade de energia transferida entre dois corpos. Segundo Wykrota (2012):

Sabemos que a energia não pode ser criada e nem destruída, mas apenas transformada de um tipo em outro. Esse é o princípio de Lavoisier. Assim, para medir a quantidade de energia transferida de um corpo para outro, vamos introduzir o conceito de Trabalho (WYKROTA, 2012, pg. 21).

Relacionar o fato de a energia não poder ser criada ou destruída ao princípio de Lavoisier não é comum entre os cientistas. O princípio de Lavoisier diz respeito à conservação das massas e, em princípio, não afirma nada sobre a natureza da energia ${ }^{6}$. Tal associação, acreditamos, só pôde ser feita porque o autor se ateve ao formalismo matemático dos princípios visto que, deste ponto de vista, a afirmação é idêntica, ou seja, a massa - tanto quanto a energia - são quantidades que se mantém constantes ao longo de determinados processos.

De qualquer forma, distinguir a natureza das afirmações e seus contextos de descoberta e aplicação nos parece mais interessante para o ensino, pois, desta forma, os diferentes conjuntos de fenômenos e processos mais fortemente associados à descoberta de um princípio que do outro servirão, cada qual, de referência para a compreensão da gramática de cada um dos conceitos e princípios em questão. Consequentemente, os diversos usos que os estudantes poderão fazer destes princípios serão avaliados diante de suas próprias gramáticas de origem, às situações de uso que deram origem à cada um deles.

No texto da aula 22 o autor parte de um possível uso popular do conceito de energia para propor por analogia uma definição do mesmo no campo da física. Segundo Wykrota (2012):

\footnotetext{
Quando dizemos que uma pessoa tem energia, podemos supor que essa pessoa tem grande capacidade de trabalhar. Quando a pessoa não tem energia, significa que diminuiu a sua capacidade de trabalhar. Essas considerações populares podem nos ajudar a entender a relação entre Energia e Trabalho, na Física. Em Física, podemos dizer que um corpo possui energia quando ele tem a capacidade de produzir Trabalho (WYKROTA, 2012, pg. 23).
}

A distinção, feita pelo autor, entre os sentidos do conceito de energia no cotidiano e na física é pertinente e coerente com a abordagem do segundo Wittgenstein. A mesma palavra, energia, teria seus usos regrados de maneira diversa em diferentes contextos de aplicação como, por exemplo, em um departamento de física teórica e em uma consulta com

6 O contexto histórico de descoberta dos princípios de conservação das massas e da energia são notoriamente diversos. 
o nutricionista. No entanto, a definição de energia como a capacidade de um corpo realizar trabalho pode levar a uma visão reducionista do conceito e, como afirmam Doménech et al. (2007), nem toda energia, por exemplo a energia interna de um corpo, pode ser convertida em trabalho. Neste sentido, a frequência do emprego desta definição no contexto escolar indica a presença de uma imagem mecanicista dogmaticamente empregada no ensino de ciências.

Observamos que entre as aulas 22 e 27, se diz que a energia mecânica se apresenta em duas formas, a saber, cinética e potencial. No entanto, a única energia potencial apresentada é a gravitacional deixando, assim, margens para que o aluno, ou mesmo o professor que utiliza o material, concluir que a energia mecânica é a soma das energias cinética e potencial gravitacional. A energia potencial elástica não é citada ao longo destes capítulos e nem mesmo considerada nas aulas sobre a conservação da energia mecânica ${ }^{7}$.

Se de um lado levantamos a hipótese de que uma visão mecânica do conceito de energia é a mais explorada e, portanto, privilegiada, do outro constatamos que mesmo esta visão mecânica do conceito se apresenta de forma reduzida no que diz respeito à sua complexidade. Além de se apresentar uma definição mais relacionada ao contexto da mecânica para o conceito de energia, se apresenta a conservação da energia mecânica exclusivamente pautada na queda de objetos na superfície do planeta Terra. Desconsiderase, portanto, as problemáticas envolvendo molas e forças elásticas de toda espécie como é o caso, inclusive, de objetos que se deformam ou deformam a superfície com que se chocam ao cair ${ }^{8}$.

Feitas essas considerações gerais sobre a apresentação do conceito de energia no contexto da mecânica, focaremos nossas análises na conservação da energia mecânica. A conservação da energia mecânica é abordado nas aulas 28 e 29 do primeiro volume da apostila e inicia com o seguinte parágrafo:

O que é necessário para que um corpo (ou partícula) se movimente? Sabemos que um corpo pode entrar em movimento quando está submetido à ação de uma Força. Neste caso, a força irá provocar um deslocamento no corpo e, portanto, irá realizar sobre ele um Trabalho (WYKROTA, 2012, pg. 29).

O trecho acima relaciona o estado de movimento de um corpo à ação de uma força sobre o mesmo e, então, atribui o movimento ao trabalho realizado por uma força sobre um corpo. Apesar de não ter explicitado, acreditamos que o autor esteja supondo o caso em que um corpo esteja em repouso para determinado referencial e que o trabalho

7 Provavelmente, a omissão da energia potencial elástica na apresentação da energia mecânica se deve às opções curriculares realizadas pelo autor, visto que o material tinha como objetivo servir de base para um curso com condições específicas de público, objetivos e duração.

Idem. 
realizado pela força sobre este corpo seja responsável por alterar seu estado do repouso para o movimento retilíneo e uniforme.

Já no segundo parágrafo, o autor enfatiza que o movimento sempre é obtido a partir da transformação de energias de diversos tipos em energia cinética. Segundo Wykrota (2012):

\begin{abstract}
Vimos que Trabalho pode ser interpretado como um tipo de Energia. Assim, para que um corpo entre em movimento, ele deve ter ou receber energia para que consiga se movimentar. Esse movimento é obtido através da transformação da Energia disponível de um tipo em outro (ou outros). Por exemplo, Energia Potencial em Energia Cinética, Energia Térmica em Energia Cinética, Energia Elétrica em Energia Cinética, etc (WYKROTA, 2012, pg. 29).
\end{abstract}

Neste trecho, destacamos dois aspectos. Em primeiro lugar, se repete a associação entre trabalho e o estado de movimento de um corpo quando, em nosso entendimento, se poderia melhor relacionar trabalho e mudança de estado de movimento. Para compreender esta ideia basta considerar que um corpo livre da atuação de forças pode apresentar movimento retilíneo e uniforme e que a atuação de uma força pode fazer com que um corpo reduza sua velocidade, e até pare, assim como é capaz de fazer com que aumente sua velocidade ou, se em repouso, se coloque em movimento. Quer dizer, o trabalho realizado por uma força sobre um corpo é tanto capaz de produzir uma aceleração positiva quanto negativa em um corpo. Em segundo lugar, chamamos a atenção para o fato de que o termo energia potencial é aplicado como sinônimo de energia potencial gravitacional desconsiderando-se portanto a possibilidade das energias potenciais elásticas, elétricas, magnéticas e outras.

Além disso, como apresentamos no capítulo anterior, trabalho e energia são conceitos semelhantes na medida em que dizem respeito a processos de transferência e transformação de energia entre sistemas físicos ou entre suas partes e, portanto, não são vistos como tipos de energia (DOMéNECH et al., 2007).

No parágrafo seguinte, é apresentado o princípio de conservação da energia pouco antes da conservação da energia mecânica:

Se possuirmos um Sistema Energeticamente Isolado (onde não há perda de energia para o meio externo), podemos enunciar o Princípio da Conservação da Energia: A Energia não pode ser criada e nem destruída, mas apenas transformada de um tipo em outro, sempre em quantidades iguais. [...] Se vamos desconsiderar as forças que dissipam a energia que os corpos possuem, é de se imaginar que não existirão perdas energéticas no movimento. [...] Assim, a Energia Mecânica do sistema permanecerá constante (será conservada) em todos os pontos do movimento do corpo (WYKROTA, 2012, pg. 29). 
A escolha do autor de apresentar o princípio de conservação da energia em uma aula onde se apresenta, exclusivamente, as energias potencial gravitacional e cinética, assim como a proximidade entre a apresentação deste princípio com a apresentação da conservação da energia mecânica, pode levar à confusões conceituais problemáticas. Uma das possíveis confusões decorrentes desta aproximação já foi suficientemente documentada e incluída na proposta de reorientação global para o ensino de energia de Doménech et al. (2007):

\begin{abstract}
Alguns livros didáticos apresentam a conservação da energia como uma generalização da conservação da energia mecânica que ocorre em algumas transformações como, por exemplo, na queda livre de uma pedra (com a ajuda da segunda lei de Newton, pode ser demonstrado, que durante a queda livre $\left.\Delta E_{k}+\Delta E_{p}=0\right)$. Entretanto, a conservação da energia para todos os processos não pode ser derivada das leis da dinâmica e se trata de uma afirmação independente (ARONS, 1999). O estabelecimento da lei de conservação requer a compreensão de interações no nível microscópico e de formas associadas de energia interna. Isto só é possível quando a relação entre efeitos mecânicos e térmicos são compreendidos (ALONSO; FINN, 1967) (DOMéNECH et al., 2007, pg. 56, tradução nossa).
\end{abstract}

Assim como o princípio de conservação da energia foi identificado com o princípio de Lavoisier, de conservação das massas, corre-se o risco de que o estudante ou o professor identifiquem o princípio de conservação da energia com a conservação da energia mecânica devido às suas semelhanças formais quando não tratados de forma aprofundada. Acreditamos que o princípio de conservação da energia poderia ser melhor apresentado, de forma a possibilitar menos confusões, a partir do estudo de diferentes tipos de configurações de sistemas e suas energias correspondentes como, por exemplo, energia química, elétrica, térmica, potencial gravitacional, potencial elástica, nuclear, etc.

Além disso, como mostramos em capítulo anterior, a origem histórica do princípio de conservação da energia possui estreita relação com os processos de conversão de energia explorados pela comunidade de engenheiros interessados em máquinas térmicas e, portanto, interessados na relação entre os efeitos mecânicos e térmicos além de, é claro, outros tipos de relações (KUHN, 1989).

Apresentaremos, agora, os exercícios resolvidos que foram apresentados ao longo dos capítulos da apostila que analisamos. O restante dos exercícios propostos ao longo da apostila são variações dos mesmos exercícios, ou seja, apresentam a mesma estrutura formal, mas variam os valores utilizados bem como a incógnita solicitada.

Cada seção de exercícios da apostila é precedida por algumas considerações qualitativas a respeito de um conceito, teorema ou princípio físico. Na medida em que se avança no texto de cada capítulo, as considerações qualitativas dão lugar à formulações matemáticas e exemplos de aplicação das mesmas à problemas numéricos fechados, ou seja, cujo resultado já está determinado pelas circunstâncias apresentadas. Os exercícios 
destinados aos estudantes também são numéricos e fechados assemelhando-se à exercícios de fixação. Não há quaisquer outros tipos de exercícios, problemas e atividades. A figura abaixo mostra um trecho da apostila onde o conceito de trabalho, bem como sua formulação matemática, é apresentado:

Figura 1 - Exercícios sobre o conceito de trabalho

TRABALHO: $\delta$

O conceito de Trabalho, em Física, está associado à idéia de que uma força que, quando aplicada a um corpo, provocará sobre o corpo um deslocamento. Ou seja, a posição do corpo será obrigatoriamente alterada. Se a força aplicada ao corpo não produz sobre ele um deslocamento, dizemos que a força não realizou Trabalho (assim, a força não transferiu energia suficiente ao corpo para que ele sofresse um deslocamento).

Matematicamente, temos: $\delta=$ F.d.cos $\alpha$ onde: $\delta=$ Trabalho $(J)$;

$\mathrm{F}=$ Força aplicada ao corpo $(\mathrm{N})$;

$\mathrm{d}=$ deslocamento sofrido pelo corpo $(\mathrm{m})$;

$\alpha=$ ângulo existente entre a força e o des-

Esquematizando, temos:

locamento do corpo $\left({ }^{\circ}\right)$

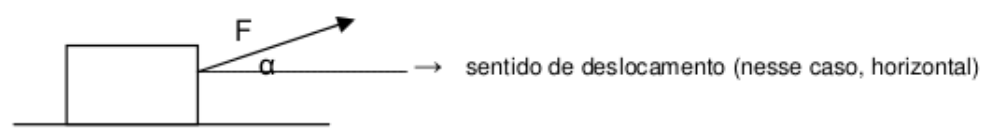

ATENCÃO: pode-se calcular o trabalho realizado por uma Força através de um gráfico Força $x$ Deslocamento ( $\mathrm{F} \times \mathrm{d}$ ). Nesse caso, basta calcular a área (retângulo, quadrado, etc) da figura apresentada no gráfico, nos intervalos desejados.

Após uma reflexão qualitativa a respeito do conceito, o texto apresenta a fórmula do trabalho, define o significado de cada uma das variáveis da fórmula e suas unidades. Logo em seguida, apresenta-se um esquema onde uma força $\mathrm{F}$ é aplicada sobre um corpo com uma inclinação $\alpha$ em relação à direção do deslocamento. Além de fornecer uma ilustração da situação onde a fórmula apresentada pode ser aplicada, o esquema ajuda a esclarecer o significado do $\cos \alpha$ presente na fórmula.

Em seguida, o texto chama a atenção do aluno para fato de que também é possível obter o valor do trabalho a partir do cálculo de área de um gráfico da Força pela distância (F x d). Por fim, uma tabela com os valores de senos e cossenos dos ângulos notáveis é fornecida a fim de que os estudantes possam consultá-las quando necessário para a resolução dos problemas propostos. 
Figura 2 - Exercícios sobre o conceito de trabalho - Parte II

TABELA DE VALORES DE SENO E COSSENO:

Para não existir a necessidade de informarmos os valores de seno e de cosseno em cada problema, apresentaremos os valores mais utilizados na Tabela abaixo. Sempre que necessário, é só consultar. Talvez você já tenha utilizado essa Tabela em Matemática.

\begin{tabular}{|c|c|c|}
\hline Ângulo $\boldsymbol{\alpha}$ & Sen $\boldsymbol{\alpha}$ & $\operatorname{Cos} \boldsymbol{\alpha}$ \\
\hline $\mathbf{0}^{\circ}$ & 0 & 1 \\
\hline $\mathbf{3 0}$ & 0,5 & 0,866 \\
\hline $\mathbf{4 5}^{\circ}$ & 0,707 & 0,707 \\
\hline $\mathbf{6 0}^{\circ}$ & 0,866 & 0,5 \\
\hline $\mathbf{9 0}$ & 1 & 0 \\
\hline \multicolumn{3}{|c|}{ Tabela 1 - valores de seno e cosseno }
\end{tabular}

\section{PROBLEMAS:}

1) Um corpo sofre um deslocamento de $10 \mathrm{~m}$, quando sofre a ação de uma força de intensidade $50 \mathrm{~N}$, conforme a indica figura abaixo. Calcule o trabalho realizado pela forca, nesse deslocamento. Desconsidere os atritos.

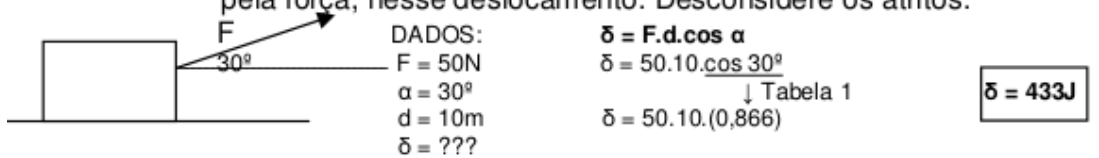

O primeiro problema de aplicação é apresentado como um paradigma de resolução dos problemas que serão propostos a seguir. Neste primeiro, trata-se da aplicação da fórmula em um caso específico onde Força, deslocamento e inclinação da força são fornecidos para que, a partir destes dados, se obtenha o valor do trabalho realizado pela força. O valor da inclinação da força com relação ao deslocamento não é apresentado no enunciado, mas num esquema que o acompanha.

Os exercícios de 2 até 4 desta seção, também requerem o cálculo do trabalho a partir das informações fornecidas. Os exercícios 5 e 6 apresentam um formato diferente. Ambos oferecem um gráfico de Força pelo deslocamento de um corpo que se desloca uma distância d sob a ação de uma força F. Novamente, o exercício 5 é apresentado como um paradigma de resolução do exercício seguinte. 
Figura 3 - Exercícios sobre o conceito de trabalho - Parte III

5) Um corpo de massa $10 \mathrm{Kg}$ movimenta-se em linha reta sobre uma mesa lisa (sem atrito), em posição horizontal, sob a ação de uma força variável que atua na mesma direção do movimento, conforme indica o gráfico FXd abaixo. Calcule o trabalho realizado pela força no deslocamento apresentado.

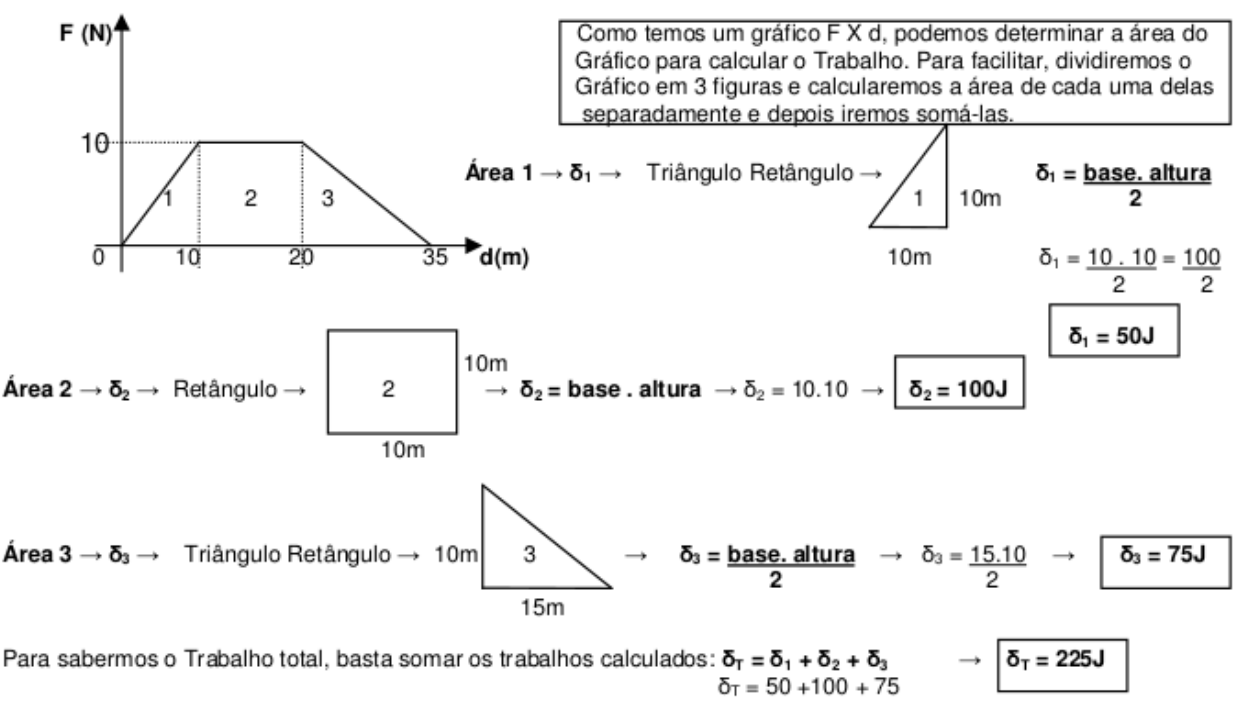

O gráfico do exercício 5 desta seção, apresenta a forma de um trapézio. O texto inclui um box onde a técnica de cálculo do trabalho a partir da área do gráfico é representada e anuncia a opção de dividir o trapézio em dois triângulos e um quadrado com a finalidade de simplificar, talvez, a resolução do exercício ou, talvez, a compreensão dos estudantes. O valor do trabalho é obtido através da somatória das três áreas calculadas a partir do gráfico.

É interessante notar que alguns dados fornecidos no enunciado são supérfluos para a resolução do exercício proposto quando se aplica a técnica sugerida. No entanto, seria possível utilizar o valor da massa do corpo para, por exemplo, se obter o valor da aceleração do corpo no trecho entre as posições 10 e 20 metros.

A figura seguinte mostra um trecho do capítulo dedicado à apresentação da energia cinética. Novamente, o texto do capítulo começa com algumas considerações qualitativas sobre o conceito de energia cinética, em seguida apresenta uma formulação matemática para o mesmo, destaca sua relação com o conceito de trabalho e, por fim, apresenta alguns exercícios resolvidos e outros para que os estudantes façam: 
Figura 4 - Exercícios sobre energia cinética

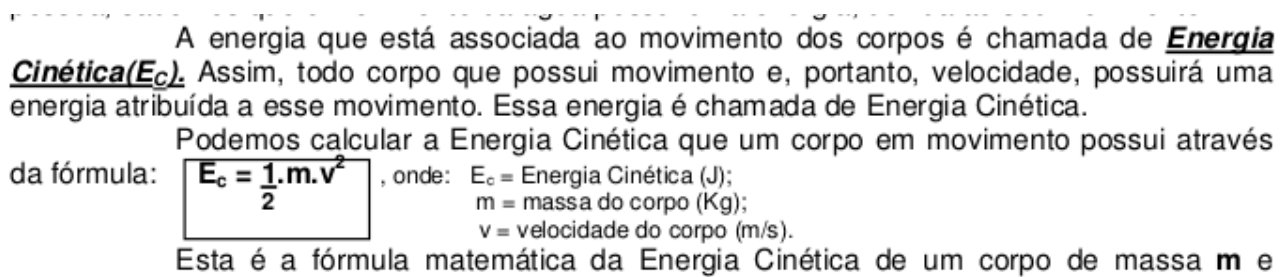
velocidade v. Ela representa o Trabalho realizado pela forca $F$ para fazer a velocidade do corpo variar de um valor inicial $\left(\mathbf{v}_{0}\right)$ até um valor final $\left(\mathbf{v}_{\mathrm{f}}\right)$. Como Trabalho é uma forma de Energia, os dois possuem a mesma unidade no Sistema Internacional (S.I.), que é o joule (J).

\section{PROBLEMAS:}

1) Um Opala de massa $1100 \mathrm{Kg}$ movimenta-se com velocidade de $20 \mathrm{~m} / \mathrm{s}$. Calcule a sua Energia Cinética.

DADOS:

$\mathrm{m}=1100 \mathrm{Kg}$

$\mathrm{v}=20 \mathrm{~m} / \mathrm{s}$

$\mathrm{E}_{\mathrm{o}}=$ ???

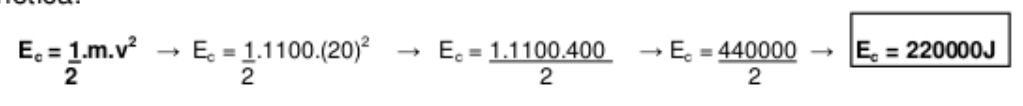

Inicialmente, o conceito de energia cinética é relacionado ao movimento dos corpos, o que seria uma boa apresentação, uma vez que, comumente, o conceito de movimento é ensinado no ensino médio como relativo ao referencial adotado e, portanto, estado de movimento ou repouso, velocidade do corpo e energia cinética poderiam ser considerados relativos ao sistema referencial. No entanto, em seguida, o texto afirma que "todo corpo que possui movimento e, portanto, velocidade, possuirá uma energia atribuída a esse movimento" dando margem para a concepção de que não exista energia cinética atribuída a corpos que se encontram em repouso em um determinado referencial. Sabemos que nesse caso a energia cinética é nula, o que não significa a ausência de energia cinética mas, antes, que tal corpo se encontra em uma situação numericamente especial dado o referencial adotado.

Além disso, o uso das expressões "movimento possuído" e "possuirá energia" na afirmação, à qual nos referimos no parágrafo anterior, pode reforçar a concepção de que a energia cinética é uma propriedade intrínseca aos objetos ou, então, que seja uma entidade armazenada no interior dos objetos. Não que este seja o conteúdo expresso pela afirmação, mas, antes, porque a combinação desta forma de apresentar a relação entre energia cinética e movimento com a ausência de uma discussão a respeito do caráter relativo do movimento e da energia cinética podem reforçar esta visão, amplamente verificada entre os estudantes. Pode-se explorar esta característica, por exemplo, através do cálculo da energia cinética a partir de diferentes referenciais mostrando que, apesar de os valores serem outros, as diferenças entre as energias cinéticas de diferentes corpos permanecem as mesmas (BUNGE, 1999).

Suponha, por exemplo, que assumamos que o valor da energia cinética de um corpo em repouso é igual à $100 \mathrm{~J}$ e que o cálculo da energia cinética dos corpos seja dado po $E_{c}=\frac{m v^{2}}{2}+E_{c 0}$, onde $E_{c 0}$ corresponda à energia dos corpos em repouso. Assim um corpo de massa $\mathrm{m}=5 \mathrm{~kg}$ e velocidade $\mathrm{v}=20 \mathrm{~m} / \mathrm{s}$ seria obtido pela equação 
$E_{c}=\frac{5.20^{2}}{2}+100=\frac{5.400}{2}+100=1000+100=1100 \mathrm{~J}$. Enquanto isso, o valor para a energia cinética, a partir da forma como habitualmente calculamos nas aulas de física, seria igual à $E_{c}=\frac{m v^{2}}{2}+0$, onde o zero representa nossa convenção implícita de que a energia cinética de um corpo em repouso seja nula. Assim, o mesmo corpo anteriormente citado teria sua energia cinética obtida por $E_{c}=\frac{5.20^{2}}{2}+0=1000 \mathrm{~J}$.

Para ambos os casos, as variações da energia cinética deste corpo partindo de uma velocidade $v_{0}$ qualquer para uma velocidade $v$ qualquer seriam as mesmas e são, justamente, as variações que importam na análise dos processos de transformação e transferência de energia e, portanto, da evolução dos sistemas físicos. Calculemos, por exemplo, a variação da energia cinética de um corpo que acelera da velocidade $v_{0}=20 \mathrm{~m} / \mathrm{s}$ para a velocidade $v=50 \mathrm{~m} / \mathrm{s}$. A partir da equação habitualmente utilizada temos que:

$$
\Delta E_{c}=\frac{m v^{2}}{2}-\frac{m v_{0}^{2}}{2}=\frac{5.50^{2}}{2}-\frac{5.20^{2}}{2}=6250-1000=5250 \mathrm{~J}
$$

enquanto que adotando o valor da energia cinética dos corpos em repouso como $100 \mathrm{~J}$ temos que

$$
\begin{gathered}
\Delta E_{c}=\frac{m v^{2}}{2}+100-\left(\frac{m v_{0}^{2}}{2}+100\right)=\frac{5.50^{2}}{2}+100-\left(\frac{5.20^{2}}{2}+100\right)=6250+100-(1000+100) \\
E_{c}=6350-1100=5250 \mathrm{~J}
\end{gathered}
$$

O mesmo trecho da apostila (Figura 4) destaca a relação entre energia cinética e trabalho afirmando que a fórmula da energia cinética apresentada "representa o Trabalho realizado pela força $\mathrm{F}$ para fazer a velocidade do corpo variar de um valor inicial $\left(v_{0}\right)$ para um valor final $\left(v_{f}\right)$ ". A preocupação em relacionar os conceitos de energia cinética e trabalho, talvez, se deva à sequência proposta pela apostila que, no capítulo seguinte, apresenta o teorema Trabalho-Energia Cinética no qual o trabalho realizado por uma força é responsável pela variação da energia cinética de um corpo.

Acreditamos, no entanto, que afirmar que $\frac{m v^{2}}{2}$ representa o trabalho realizado por uma força que leva um corpo de uma velocidade à outra talvez não expresse tão bem o fato que, supomos, se desejava, a saber, o de que o valor da energia cinética de um corpo com velocidade $\mathrm{v}$ em determinado referencial corresponde ao valor do trabalho realizado por uma força $\mathrm{F}$ para aumentar a velocidade do mesmo corpo de $v_{0}=0$ para $v_{f}=v$. Ou seja, a afirmação somente seria verdadeira para $v_{0}=0$ e se fizesse referência ao valor numérico da expressão uma vez que a aplicação do conceito de energia cinética, de sua fórmula matemática, não pressupõe que um corpo tenha sido acelerado desde o repouso. Além disso, a energia cinética obtida pela fórmula apresentada também pode corresponder ao módulo do valor numérico do trabalho realizado por uma força $\mathrm{F}$ que desacelere o corpo em questão de uma velocidade $\mathrm{v}$ até o repouso. 
Provavelmente, esta maneira de apresentar o conceito de energia cinética se deva, como dissemos, apenas à preocupação do autor em aproximar o estudante do teorema da energia cinética.

Figura 5 - Exercícios sobre energia cinética - Parte II

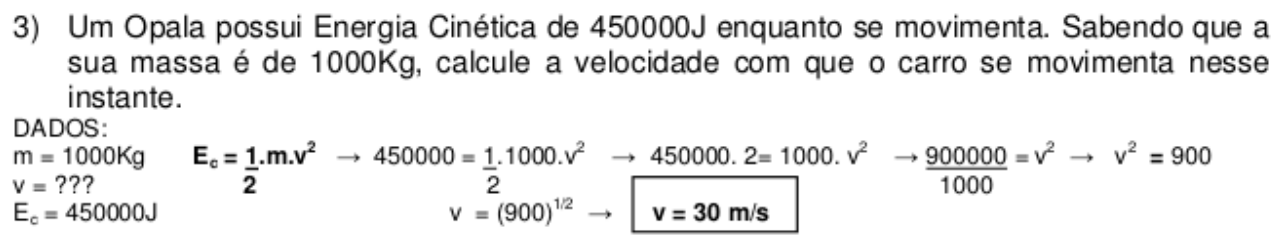

Novamente, são apresentados dois paradigmas de resolução de exercícios fechados: um para a obtenção do valor de energia cinética em determinada situação cujos demais valores são todos fornecidos e outra para a obtenção da velocidade dos corpos em situações semelhantes. Os exercícios 1 e 2 são do primeiro tipo e os exercícios de 3 até 8, do segundo.

Conforme Doménech et al. (2007) sugerem, nenhuma consideração a respeito do caráter relativo da velocidade e, portanto, da energia cinética foi apresentada no texto, podendo, assim, reforçar a concepção de que os valores de energia cinética sejam absolutos e relativos aos corpos por si mesmos, contribuindo também com a concepção de energia como ente ou propriedade intrínseca de corpos isolados.

Na sequência, apresenta-se o teorema da energia cinética que afirma que o trabalho realizado por uma força resultante é responsável pela variação da energia cinética de um corpo. Este teorema, por incluir a variação da energia cinética, permite a análise de processos de transferência e transformação de energia.

Na organização do texto da apostila, o teorema da energia cinética é apresentado como uma síntese dos conteúdos vistos anteriormente: trabalho e energia cinética. Dessa maneira, uma nova formulação matemática relaciona as grandezas força, deslocamento, massa e variação de velocidade entre si. A formulação do teorema poderia ser explicitada assim:

$$
\tau=\Delta E_{c} \Rightarrow F . d=E_{c f}-E_{c i} \Rightarrow F . d=\frac{m v_{f}^{2}}{2}-\frac{m v_{i}^{2}}{2}
$$

, onde $\tau$ é o trabalho, $E_{c}$ é a energia cinética, $\mathrm{F}$ é a força resultante sobre um corpo, m é a massa do corpo e v sua velocidade. 
Figura 6 - Exercícios sobre Teorema Trabalho-Energia Cinética

Considere um corpo qualquer de massa $\mathrm{m}$ que se movimenta com uma velocidade inicial $\left(\mathbf{v}_{0}\right)$. Sob a ação de uma força resultante, vamos considerar que a velocidade do corpo seja alterada, tornando-se, portanto, uma velocidade final $\left(\mathbf{v}_{\mathbf{t}}\right)$.

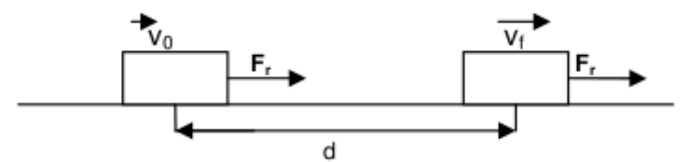

Se utilizarmos adequadamente as definições matemáticas de Trabalho (ס), da ₹̊ Lei de Newton e da Equação de Torricelli, obteremos como resultado:

$$
\begin{aligned}
& \delta=\Delta_{\text {Energia Cinética }} \rightarrow \text { LEMBRANDO QUE } \Delta \text { SIGNIFICA VARIAÇÃO, EM FíSICA }
\end{aligned}
$$

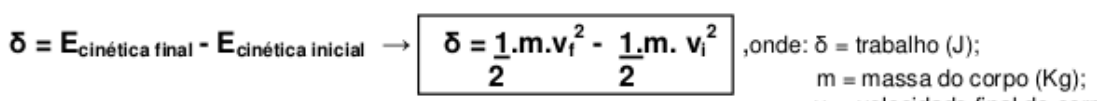

$$
\begin{aligned}
& \mathrm{v}_{\mathrm{f}}=\text { velocidade final do corpo }(\mathrm{m} / \mathrm{s}) \text {; } \\
& v_{i}=\text { velocidade inicial do corpo }(\mathrm{m} / \mathrm{s})
\end{aligned}
$$

Através dessa dedução matemática, podemos enunciar o Teorema da Energia Cinética: O Trabalho realizado pela Força Resultante que atua sobre um corpo é igual à variação da Energia Cinética desse corpo.

O texto menciona a possibilidade de obter este teorema a partir da manipulação algébrica das formulações matemáticas das leis da dinâmica e da equação de Torricelli e, em seguida, indica o significado de cada uma das variáveis da equação e suas unidades. Além disso, faz uma lista das possíveis aplicações deste teorema no campo da física. Neste ponto, é interessante destacar que, apesar de não explorar nesta seção da apostila, o autor menciona que este teorema possui aplicações em diferentes áreas da física no momento em que afirma que o mesmo permite medir os diferentes tipos de energia transferidos para uma partícula em movimento.

Figura 7 - Exercícios sobre Teorema Trabalho-Energia Cinética - Parte II

Este Teorema possui grande utilidade na Física, principalmente em Mecânica. Utilizando-o, é possível calcular:

- a velocidade de uma partícula a partir de uma velocidade conhecida e do cálculo do trabalho das forças aplicadas.

- permite calcular o Trabalho realizado por certos tipos de Força, a partir de uma variação da velocidade da partícula; movimento.

- permite medir os diferentes tipos de energia transferidos para uma partícula em

\section{PROBLEMAS:}

1) Um corpo de massa $10 \mathrm{Kg}$ realiza um movimento retilíneo sobre um plano horizontal sem

\begin{tabular}{|c|c|c|}
\hline \multirow[t]{2}{*}{$\begin{array}{l}\text { DADOS: } \\
\mathrm{m}=10 \mathrm{Kg} \\
\delta=? ? ? \\
\mathrm{v}_{0}=10 \mathrm{~m} / \mathrm{s} \\
\mathrm{v}_{\mathrm{t}}=40 \mathrm{~m} / \mathrm{s}\end{array}$} & $\begin{array}{l}\text { Como não temos o valor da força nem o Deslocamento, } \\
\text { o Trabalho será igual à Variação da Energia Cinética. } \\
\qquad \delta=\frac{1}{\mathbf{2}} \cdot \mathbf{m} \cdot \mathbf{v}_{\mathrm{t}}^{2}-\frac{\mathbf{1}}{\mathbf{2}} \mathbf{m} \cdot \mathbf{v}_{\mathrm{i}}^{2}\end{array}$ & \multirow{2}{*}{$\begin{array}{l}\delta=\frac{1}{2} \cdot \mathrm{m} \cdot \mathrm{v}_{\mathrm{f}}{ }^{2}-\frac{1}{2} \cdot \mathrm{m} \cdot \mathrm{v}_{\mathrm{i}}^{2} \\
\delta=\frac{1}{2} \cdot 10 \cdot(40)^{2}-\frac{1}{2} \cdot 10 \cdot(10)^{2} \\
\delta=\frac{1 \cdot 10 \cdot 1600}{2}-\frac{1 \cdot 10 \cdot 100}{2} \\
\delta=\frac{16000}{2}-\frac{1000}{2} \\
\delta=8000-500 \rightarrow \delta=7500 \mathrm{~J}\end{array}$} \\
\hline & & \\
\hline
\end{tabular}
atrito. Qual é o trabalho realizado por uma força que faz esse corpo variar a sua velocidade de $10 \mathrm{~m} / \mathrm{s}$ para $40 \mathrm{~m} / \mathrm{s}$ ?

Por fim, o texto apresenta - nos moldes já descritos anteriormente - exercícios de aplicação do teorema da energia cinética. O conjunto de exercícios propostos apresenta 
dois paradigmas de aplicação do teorema, um para que se calcule o trabalho realizado pela força resultante que age sobre um corpo que tem sua energia variada e outro para que se calcule a intensidade da força resultante. Em ambos os casos, os valores de todas as variáveis restantes são diretamente fornecidos pelo enunciado.

Figura 8 - Exercícios sobre Teorema Trabalho-Energia Cinética - Parte III

4) Uma força constante e horizontal, de módulo $\mathrm{F}$, atua sobre um corpo de massa $12 \mathrm{Kg}$, fazendo com que a sua velocidade varie de $2 \mathrm{~m} / \mathrm{s}$ para $10 \mathrm{~m} / \mathrm{s}$. Sabendo que o corpo sofreu um deslocamento horizontal de $24 \mathrm{~m}$, determine o valor da força $\mathrm{F}$.
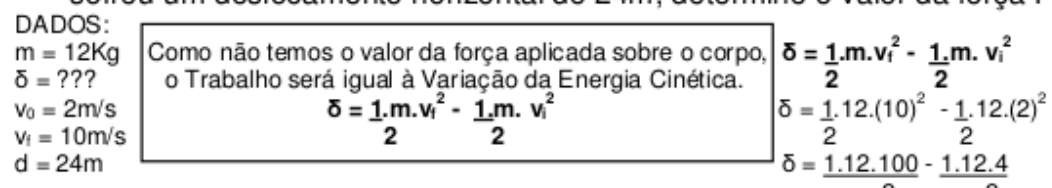

Assim, a intensidade da Força que atua sobre o corpo é de $\overrightarrow{24} \mathrm{~N}$.

Sobre a apresentação do conceito de trabalho e do teorema da energia cinética, gostaríamos de mencionar a escolha do texto em apresentar apenas situações em que os valores de trabalho e variação da energia cinética são positivos, ou seja, situações em que a força resultante e o deslocamento dos corpos apresentam o mesmo sentido. Dessa forma, os estudantes podem interpretar que, necessariamente, a aplicação de forças sobre os corpos gere o aumento de suas velocidades ou, ainda, os estudantes podem ter dificuldades em compreender relação entre energia e os processos de frenagem.

O conceito de energia potencial gravitacional é apresentado como a energia interna de um corpo ou sistema de corpos a partir da qual podem ocorrer deslocamentos de suas partes (dos corpos ou sistemas) e, portanto, está relacionada com o conceito de trabalho. Segundo Wykrota (2012):

Um corpo ou um sistema de corpos pode ter forças interiores capazes de modificar a posição relativa de suas diferentes partes. Como essas forças podem provocar deslocamento sobre o corpo, elas podem realizar trabalho $(\delta)$. Então, podemos entender que esses corpos possuem um tipo de energia. Essa energia é chamada de Energia Potencial, ou Energia de Posição, porque se deve à posição relativa que ocupam as diversas partes do corpo ou do sistema de corpos. É graças a essa energia que quando um carro é abandonado numa rampa, ele entra em movimento, ou a água se movimenta num rio, etc (WYKROTA, 2012, pg. 27).

O texto reconhece e explicita o caráter sistêmico e relativo do conceito de energia potencial gravitacional e apresenta alguns exemplos de fenômenos que podem ser explicados a partir deste tipo de energia. Nos exemplos, ficam subentendidos que o carro, a rampa e 
o restante do planeta constituem um sistema assim como as águas dos rios e o planeta Terra.

As forças de interação entre os corpos, no caso a força gravitacional, também são importantes para a compreensão desta forma de energia. Não bastam as posições relativas dos corpos de um sistema, é necessário que existam forças de interação entre estes corpos para que o conceito de energia potencial gravitacional faça sentido. Este aspecto do conceito, de sua dependência de forças de interação, é tratado de forma implícita na medida em que se menciona a aceleração gravitacional na superfície da Terra. É interessante notar, por exemplo, que o potencial eletrostático depende dos sinais das cargas que interagem entre o que evidencia a importância da natureza das forças de interação para a compreensão das energias potenciais.

Figura 9 - Exercícios sobre energia potencial gravitacional

Considere um corpo de massa m posicionado próximo ao solo, a uma determinada altura (h) em relação ao solo, num local onde a aceleração da gravidade é $\boldsymbol{g}$, conforme indica a figura abaixo:

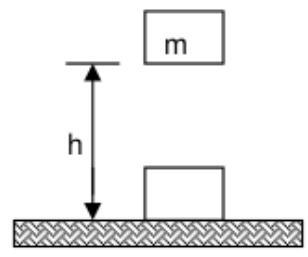

O Trabalho realizado por uma pessoa para elevar o corpo do solo até a altura $\mathbf{h}$ com velocidade constante, deve ser igual à Energia Potencial Gravitacional que o corpo possui nessa posição, pois se o corpo for abandonado, entrará em movimento, caindo em direção ao solo, sendo a força Peso do corpo (P) a responsável por fazê-lo entrar em movimento. Assim, temos:

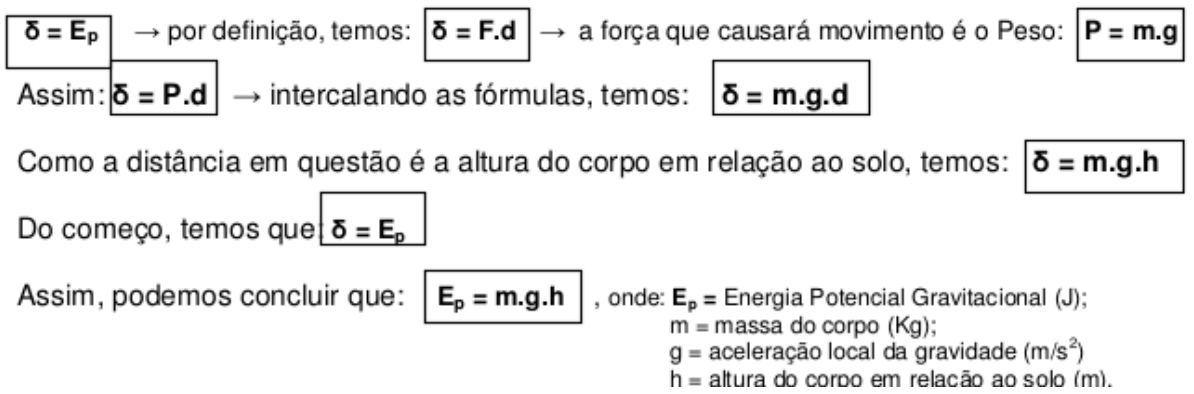

Em seguida, o texto apresenta um diagrama representando um corpo em duas alturas distintas com relação ao solo, uma no nível do solo e outra à uma altura h do mesmo, e relaciona ao corpo que se encontra nesta posição o trabalho realizado por uma força aplicada por uma pessoa para erguê-lo do solo até uma altura h com velocidade constante. Por fim, relaciona-se o trabalho realizado pela pessoa ao trabalho realizado pela força peso do corpo, no sentido contrário, e se deriva daí a fórmula da energia potencial gravitacional de um corpo de massa m à uma altura h da superfície da Terra.

É importante refletir sobre as diferenças entre os usos do conceito de trabalho nos casos do teorema da energia cinética e da energia potencial gravitacional. No primeiro caso, a força levada em consideração é a resultante, ou seja, aquela força abstrata que representa 
o efeito da ação de todas as forças que atuam sobre o corpo em questão e que, portanto, não sendo nula - e sendo aplicada sobre um ponto material - resultará inevitavelmente em aceleração. No segundo caso, a força considerada é a de um agente que suspende o corpo mantendo sua velocidade constante, ou seja, sem aceleração. Neste caso, a força aplicada pelo agente precisa, necessariamente, ser igual à força de atração entre o corpo erguido e o planeta Terra para que, assim, a resultante das forças seja nula e toda a força aplicada pelo agente se converta em altura (Energia potencial gravitacional) e não em velocidade (Energia cinética).

Esta situação pode parecer confusa aos estudantes, uma vez que se relaciona, com maior frequência, a força resultante nula ao repouso que ao movimento retilíneo uniforme. Além disso, a situação proposta apresenta um corpo em repouso sobre o solo que precisa estar sob a ação de uma força resultante não nula para entrar em movimento. Os estudantes podem se perguntar "Como podemos colocar um corpo em movimento com uma resultante nula?" ou "Como uma força resultante não nula pode produzir um movimento uniforme para cima?". Acontece que pode-se imaginar que uma força resultante não nula aja sobre o objeto por uma fração de segundos até colocá-lo em movimento para cima com uma velocidade v qualquer e, em seguida, se reduza a força aplicada ao corpo de forma que a resultante das forças seja nula e o movimento siga uniforme para cima até que o corpo atinja a altura desejada. No final do processo, quando o corpo alcançar a altura necessária será necessário permitir que a força peso seja maior por uma fração de tempo, de forma que a velocidade se anule para, então, retornar à situação de equilíbrio de forças.

Esta situação complexa é simplificada e diversos de seus elementos são implicitamente considerados de forma que se foque na relação entre a altura final do corpo e o trabalho da força peso para que, assim, seja possível associar a energia potencial gravitacional ao aumento da velocidade de um corpo em queda livre através do teorema da energia cinética.

Figura 10 - Exercícios sobre energia potencial gravitacional - Parte II

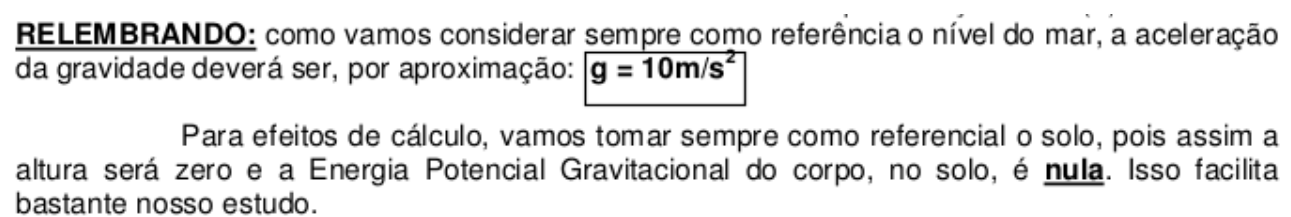
bastante nosso estudo.

PROBLEMAS:

1) Um corpo de massa $20 \mathrm{Kg}$ encontra-se localizado a uma altura de $6 \mathrm{~m}$, em relação ao DADOS: solo. Calcule a sua Energia Potencial Gravitacional nessa posição.

$\begin{array}{ll}m=20 \mathrm{Kg} & E_{p}=\text { m.g.h } \\ h=6 \mathrm{~m} & E_{p}=20.10 .6 \rightarrow E_{p}=1200 \mathrm{~J} \\ g=10 \mathrm{~m} / \mathrm{s}^{2} & \rightarrow \mathrm{E}^{2}\end{array}$

Em seguida, o texto apresenta uma dedução da equação da energia potencial gravitacional a partir da formulação matemática do conceito de trabalho, esclarece o significado das variáveis bem como suas unidades. 
Antes de apresentar os exercícios de aplicação propostos para os estudantes, o texto chama a atenção do leitor para dois aspectos convencionais que serão adotados em todos os exercícios, a saber, o fato de que o valor da aceleração da gravidade g adotada corresponderá a seu valor no nível do mar e que a altura h será medida a partir do solo local, ou seja, sem considerar se o solo em questão é de uma praia no nível do mar ou do alto de uma montanha a 3 mil metros de altitude com relação ao nível do mar. As convenções são justificadas pela facilidade que proporcionam nos cálculos.

Em nossa opinião, o fato de mencionar estes aspectos convencionais e justificar estas escolhas com base na facilidade proporcionada para a resolução dos problemas é um aspecto positivo do texto, aspecto muitas vezes negligenciado nos materiais didáticos e no processo de ensino do conceito de energia potencial gravitacional. No entanto, também gostaríamos de mencionar que, como Doménech et al. (2007) já afirmaram, esta reflexão acerca da natureza sistêmica e relativa da energia é mais frequentemente abordada com relação à energia potencial gravitacional que com relação à energia cinética.

Mesmo assim, a partir destas considerações poder-se-ia aprofundar em temáticas como a possibilidade de estudar fenômenos energéticos a partir de diferentes referenciais ou, então, sobre a viabilidade de se adotar diferentes referenciais para a altura h e o valor de aceleração da gravidade g na resolução de problemas. Seria possível, por exemplo, avaliar a diferença numérica nos resultados obtidos a partir da consideração dos valores exatos e a partir de resoluções que utilizem as aproximações propostas.

Figura 11 - Exercícios sobre energia potencial gravitacional - Parte III

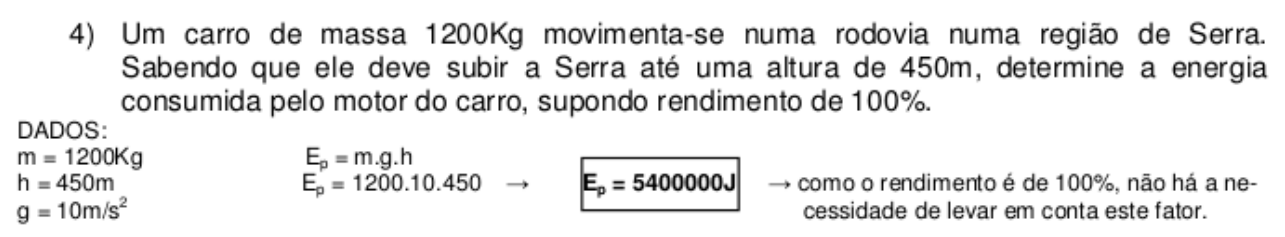

5) Um carro de massa $950 \mathrm{Kg}$ movimenta-se numa rodovia numa região de Serra. Sabendo que ele deve subir a Serra até uma altura de $500 \mathrm{~m}$, determine a energia consumida pelo motor do carro, supondo rendimento de $45 \%$.

Dois paradigmas de resolução de exercícios são apresentados. Cada um deles correspondendo a um tipo de exercício proposto. O primeiro tipo solicita o cálculo da energia potencial gravitacional de um corpo de massa $\mathrm{m}$, à altura h sob a ação de uma aceleração gravitacional g. O outro tipo solicita o cálculo da energia consumida por motores de automóveis, com diferentes índices de eficiência em transformar energia de combustível em deslocamento, que se deslocam do nível do mar até determinadas alturas. Em todos os exercícios propostos os valores das variáveis necessários para o cálculo são fornecidas diretamente nos enunciados.

Ao propor uma situação em que nem toda a energia do combustível é convertida em altura o enunciado abre espaço para discussões acerca dos diferentes fins da energia 
empregada em um motor, em uma máquina. Tais reflexões podem conduzir às questões da transformação da energia do combustível em energia interna das partes do carro, da impossibilidade de construir um sistema termodinâmico com $100 \%$ de eficiência e, consequentemente, sobre a "degradação da energia" e a crise energética global.

No capítulo seguinte, é apresentada a conservação da energia mecânica juntamente com os exercícios de aplicação propostos para os estudantes:

Figura 12 - Exercícios sobre Conservação da energia mecânica

Se vamos desconsiderar as forças que dissipam a energia que os corpos possuem, é de se imaginar que não existirão perdas energéticas no movimento. Assim, toda a energia mecânica que o corpo possuir será utilizada para fazê-lo se movimentar, sem nenhum tipo de dificuldade, atrapalho ou perdas. Assim, a Energia Mecânica do sistema permanecerá constante (será conservada) em todos os pontos do movimento do corpo. Então, podemos enunciar o Principio da Conservação da Energia Mecânica:

Em um sistema conservativo, a Energia Mecânica Total permanece constante.

Matematicamente, podemos escrever:

$$
\begin{aligned}
E_{m}=E_{c}+E_{p}=\text { CONSTANTE , onde: } & E_{m}=\text { Energia Mecânica }(J) ; \\
& E_{c}=\text { Energia Cinética }(J) ; \\
& E_{p}=\text { Energia Potencial }(J) ;
\end{aligned}
$$

ATENCC̃̃O: esse Princípio só pode ser utilizado para Sistemas Conservativos. Para sistemas não conservativos, o resultado poderá não ser necessariamente uma constante.

\section{PROBLEMAS:}

1) Um corpo de massa $10 \mathrm{Kg}$ é abandonado a partir do repouso de uma altura de $45 \mathrm{~m}$, num local onde a aceleração da gravidade é $\mathrm{g}=10 \mathrm{~m} / \mathrm{s}^{2}$. Calcule a velocidade desse corpo ao atingir o solo. Considere que o sistema seja conservativo.

O exercício para o qual o texto oferece um paradigma de resolução solicita o cálculo do valor da velocidade de um corpo ao final de uma trajetória de queda livre. Alguns dos valores são fornecidos diretamente pelo enunciado do exercícios como, a massa $\mathrm{m}=10 \mathrm{~kg}$, a aceleração da gravidade $\mathrm{g}=10 \mathrm{~m} / \mathrm{s}^{2}$ e a altura $h_{A}=45 \mathrm{~m}$. Outros valores são fornecidos através de afirmações como "abandonado a partir do repouso" $\left(v_{0}=0\right)$ e "ao atingir o solo" $\left(h_{B}=0\right)$, sendo A e B índices para a identificação das duas situações, antes e depois da queda. Estas interpretações do enunciado são sugeridas na esquematização da resolução do exercício: 
Figura 13 - Exercícios sobre Conservação da energia mecânica - Parte II

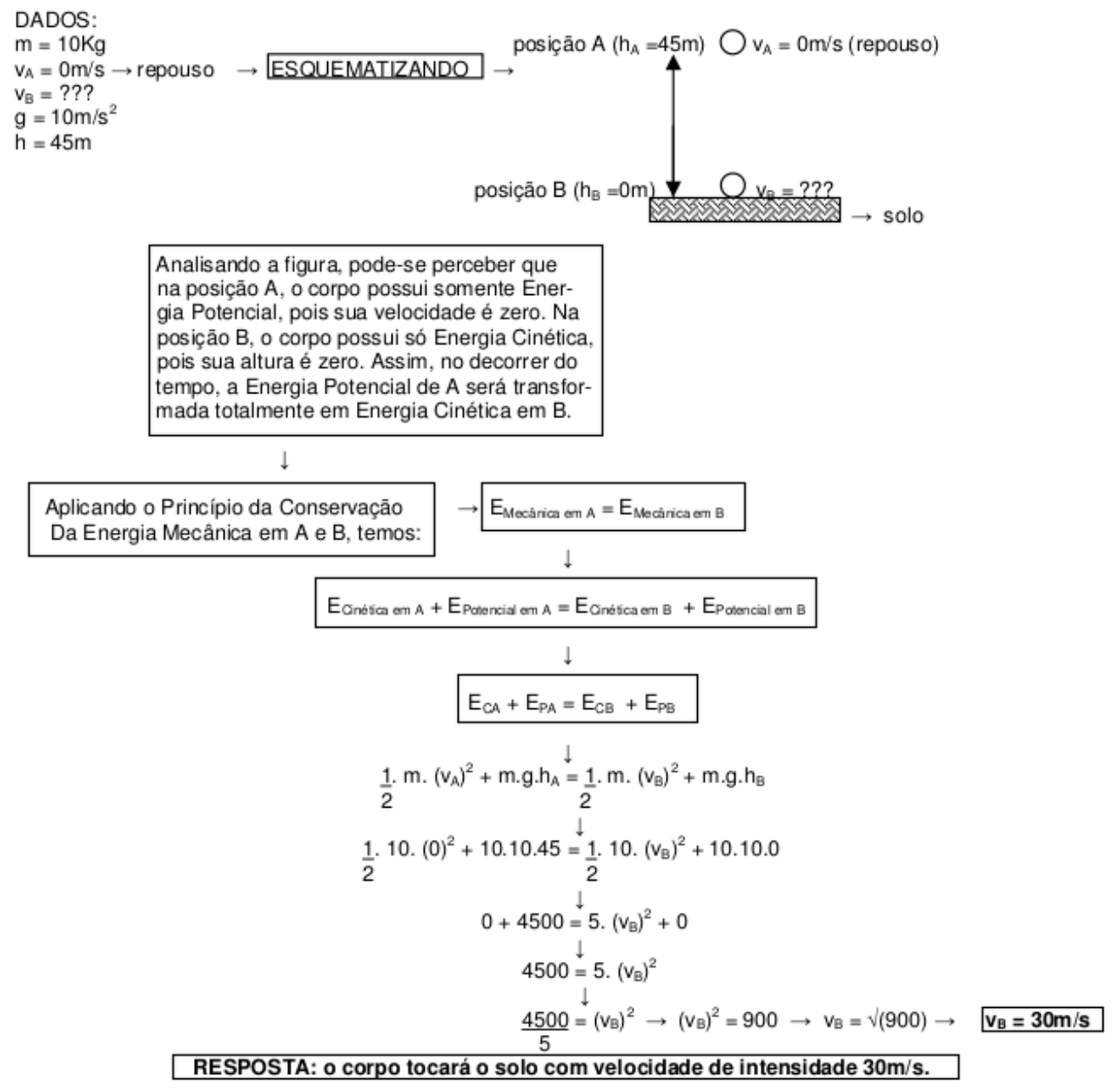

A resolução do exercício apresenta uma formulação matemática para a conservação da energia mecânica $\left(E_{m a}=E_{m b}\right)$ e a reescreve de forma a explicitar as componentes cinética e potencial desta formulação $\left(E_{c a}+E_{p a}=E_{c b}+E_{p b}\right)$ para, em seguida, expandi-la para a equação a seguir:

$$
\frac{m v_{a}^{2}}{2}+m g h_{a}=\frac{m v_{b}^{2}}{2}+m g h_{b}
$$

A substituição dos valores oferecidos direta e indiretamente pelo enunciado nesta equação deixa apenas uma incógnita a ser calculada.

Gostaríamos de fazer três observações com relação à resolução deste exercício por meio da conservação da energia mecânica. A primeira delas diz respeito às afirmações apresentadas dentro do primeiro quadro de considerações para a resolução do exercício, são elas, "na posição A, o corpo possui somente energia potencial, pois sua velocidade é zero" e "na posição B, o corpo possui somente energia cinética, pois sua altura é zero". Estas afirmações afirmam implicitamente que um corpo com energia, por exemplo, cinética e potencial nula não possuem energia cinética ou potencial quando, como já discutimos, estes valores apenas refletem a escolha de um referencial para o tratamento do problema. 
Nossa segunda observação diz respeito ao fato de que todos os exercícios propostos neste capítulo se tratem de corpos que caem, a partir do repouso, de uma determinada altura até o solo. Não há questões envolvendo, por exemplo, a queda de corpos de uma altura até outra altura intermediária e diferente de zero, a análise de movimentos de queda de corpos que apresentam velocidade inicial diferente de zero ou, ainda, a desaceleração de corpos lançados de determinada altura, a partir do solo ou não, para cima. Acreditamos que esta variedade de tipos de exercícios seja fundamental para a compreensão do princípio de conservação da energia mecânica.

Por fim, gostaríamos de chamar a atenção para o fato de que o texto optou por apresentar e exercitar apenas a energia potencial gravitacional, omitindo, assim, a energia potencial elástica comumente abordada no contexto da energia mecânica.

Insistimos, ainda, no fato de que o princípio de conservação da energia tenha sido apresentado juntamente com o princípio de conservação da energia mecânica, como já dissemos anteriormente. Não estamos dizendo que o texto apresenta o princípio de conservação da energia e a conservação da energia mecânica de forma confusa, sem saber diferenciar um do outro, mas que esta aproximação entre eles, sem a consideração de fenômenos da termodinâmica e do eletromagnetismo, podem contribuir para uma imagem mecanicista da energia e de sua conservação o que não faria justiça ao seu caráter de princípio geral da física visto que no contexto mecânico costumamos ver o aquecimento pelo atrito ou impacto como perdas de energia.

É importante ressaltar que, de forma alguma, temos a intenção de direcionar nossas críticas ao autor que, gentilmente, produziu e disponibilizou este material de apoio para livre acesso através da internet. Relembramos que o material foi preparado para a utilização no contexto do ensino na modalidade E.J.A. que, carece de uma política pública de produção e distribuição de materiais didáticos. Entendemos que boa parte dos aspectos para os quais chamamos a atenção seja fruto de um processo de transposição didática para atender um contexto cujo tempo, recursos e público apresentem características particulares.

Nosso principal interesse com esta análise é refletir sobre alguns aspectos do ensino do conceito de energia que parecem estar presentes tanto nas esferas mais gerais, caso dos livros didáticos aprovados pelo PNLD, como nas esferas mais concretas e particulares, caso das aulas de física que acompanhamos e do material didático produzido pelo professor Wykrota e utilizado por dezenas de professores. Nosso intuito é, em suma, apontar para tendências mais gerais e amplamente difundidas no que diz respeito à maneira como o conceito físico de energia é ensinado nos cursos de física do ensino médio. Tendências as quais, inclusive, os professores estão submetidos. 


\subsubsection{Os exercícios propostos pelo professor}

Além dos exercícios propostos pelo material didático adotado, o professor solicitou que os alunos resolvessem outros exercícios como forma de avaliação do aprendizado. A maioria destes exercícios são problemas numéricos muito semelhantes aos exercícios propostos pela apostila. Seguem alguns dos exercícios que se destacaram:

3 - Imagine que você deixa cair (abandonado) um objeto de massa m e de altura de 51,2 metros. Determine a velocidade desse objeto ao tocar o solo.

6 - Conta-se que Newton teria descoberto a lei da gravitação ao lhe cair uma maçã na cabeça. Suponha que Newton tivesse $1,70 \mathrm{~m}$ de altura e se encontrassem em pé e que a maçã, de massa $0,20 \mathrm{~kg}$, tivesse se soltado, a partir do repouso, de uma altura de 3,00m do solo. Admitindo-se g = $10 \mathrm{~m} / \mathrm{s}^{2}$ e desprezada a resistência do ar, pode-se afirmar que a energia cinética da maçã, ao atingir a cabeça de Newton, seria, em joules, de: a) 0,60 b) 2,00 c) 2,60 d) 6,00 e) 9,40

Nosso destaque ao exercício 3 se deve ao fato de que tal exercício permite que o aluno, ao tentar resolvê-lo por meio dos paradigmas de resolução já dominados, se questione a respeito da necessidade de se conhecer a massa do corpo em questão para determinar sua velocidade ao final de uma queda livre de uma altura conhecida. Inicialmente, os estudantes poderão estranhar a ausência deste dado, mas depois, com ou sem a ajuda do professor, poderão verificar que essa informação não é necessária, visto que as massas das energia mecânica ao início e ao final do processo se anularão mutuamente. Apresentamos, em seguida, uma possível resolução para o exercício:

$E_{m A}=E_{m B} \Rightarrow \frac{m v_{A}^{2}}{2}+m g h_{A}=\frac{m v_{B}^{2}}{2}+m g h_{B} \Rightarrow m\left(\frac{v_{A}^{2}}{2}+g h_{A}\right)=m\left(\frac{v_{B}^{2}}{2}+g h_{B}\right) \Rightarrow$ $\frac{m}{m}\left(\frac{v_{A}^{2}}{2}+g h_{A}\right)=\frac{v_{B}^{2}}{2}+g h_{B} \Rightarrow \frac{v_{A}^{2}}{2}+g h_{A}=\frac{v_{B}^{2}}{2}+g h_{B}$, como o corpo cai a partir do repouso e a altura é nula quando o corpo toca o solo, temos que $v_{A}=h_{B}=0$, então, $\frac{0^{2}}{2}+10.51,2=\frac{v_{B}^{2}}{2}+10.0 \Rightarrow 512=\frac{v_{B}^{2}}{2} \Rightarrow v_{B}=\sqrt{2.512} \Rightarrow v_{B}=\sqrt{1024} \Rightarrow v_{B}=32 \mathrm{~m} / \mathrm{s}$

Este tipo de exercício pode conduzir os estudantes à questionamentos como, por exemplo, "Se o corpo em queda fosse muito mais pesado que este a velocidade final seria a mesma?" ou "Quer dizer que corpos de diferentes massas caem com a mesma velocidade?" permitindo, assim, que se relacione o estudo dos movimentos pela abordagem energética com os estudos de cinemática, costumeiramente trabalhados no início do primeiro ano do ensino médio.

Destacamos o exercício 6 porque o mesmo propõem a análise das implicações da conservação da energia mecânica em uma situação diferente dos extremos, da altura máxima ou mínima, uma situação de altura intermediária onde há, portanto, uma fração da energia mecânica na forma cinética e outra na forma potencial gravitacional. Além disso, este exercício permite diferentes métodos de resolução que podem ajudar a compreender o 
caráter relativo da energia potencial gravitacional. Em seguida, apresentamos aquilo que acreditamos que seja a resolução mais comum do exercício:

A partir do fato de que $E_{m A}=E_{m B}$ e adotando o nível do solo como h $=0$, temos que: $\frac{m v_{A}^{2}}{2}+m g h_{A}=E_{c B}+m g h_{B} \Rightarrow \frac{0,2.0^{2}}{2}+0,2.10 .3=E_{c B}+0,2.10 .1,7 \Rightarrow 0+6=$ $E_{c B}+3,4 \Rightarrow E_{c B}=6-3,4=2,6 J$.

No entanto, podemos resolver o mesmo exercício adotando que a posição da cabeça de Newton corresponda à altura zero $(\mathrm{h}=0)$ e, consequentemente, a altura da maçã corresponda a 1,3 m em nosso referencial. Assim, temos que: $\frac{m v_{A}^{2}}{2}+m g h_{A}=E_{c B}+m g h_{B} \Rightarrow$ $\frac{0,2.0^{2}}{2}+0,2.10 .1,3=E_{c B}+0,2.10 .0 \Rightarrow 2,6 J=E_{c B}$.

Enquanto na primeira resolução a energia cinética era obtida a partir da diferença entre as energias potenciais gravitacionais nos pontos A e B, na segunda resolução a energia cinética representa toda a energia potencial gravitacional do corpo no referencial adotado ou, de outra forma, a diferença das energias potenciais gravitacionais nos pontos A e B sendo que, no ponto B, a energia potencial gravitacional é nula por construção.

Além desses exercícios, os alunos responderam à algumas questões conceituais. São elas:

1 - O que é energia?

2 - Quais são os principais tipos de energia que consumimos?

3 - Cite exemplos de transformações de energias

Quatro dos cinco alunos selecionados para uma análise mais detalhada responderam à questão "O que é energia?" afirmando que se trata da capacidade de um corpo de realizar trabalho. Segue a resposta do indivíduo $\mathbf{E}$ :

Energia em si, é um conceito intuitivo, pois cada um pode enunciar de maneira diferente. A mesma não pode ser destruída, e sim apenas transformada de um tipo para outro. Ela pode manifestar-se de diferentes formas e todas elas estão relacionadas à capacidade de produzir trabalho, ação e movimento.

É interessante que a resposta de E começa reconhecendo que o conceito pode ser enunciado de diferentes formas, mas, em seguida, afirma que todas essas formas podem ser reduzidas à capacidade de realizar trabalho, ação e movimento. Esta é, sem dúvida, a expressão de uma concepção mecanicista do conceito de energia.

Além disso, a resposta de E nos permite inferir sobre a forte influência do material didático selecionado pelo professor de física nas concepções de energia dos alunos, visto o alto grau de semelhança entre as explicações contidas no material e a expressa pelo indivíduo E. Segundo Wykrota (2012): 
O conceito de energia pode ser considerado intuitivo, pois cada um de nós pode enunciar este conceito de maneiras muito diferentes, porém corretas. Isso acontece, pois não podemos tocar com as mãos ou visualizar a energia. Sabemos que ela existe devido aos seus efeitos que podem ser visualizados com facilidade (WYKROTA, 2012, pg. 21).

Ou ainda:

\begin{abstract}
Quando dizemos que uma pessoa tem energia, podemos supor que essa pessoa tem grande capacidade de trabalhar. Quando a pessoa não tem energia, significa que diminuiu a sua capacidade de trabalhar. Essas considerações populares podem nos ajudar a entender a relação entre Energia e Trabalho, na Física. Em Física, podemos dizer que um corpo possui energia quando ele tem a capacidade de produzir Trabalho (WYKROTA, 2012, pg. 23).
\end{abstract}

O estudante que não se enquadrou nesse tipo de resposta se limitou a explicitar uma vaga noção da conservação e transformação da energia. Segundo o indivíduo C:

Energia é algo produzido por um corpo, que pode ser apenas transformado e não destruído. Por exemplo, a energia elétrica.

Apesar de não reproduzir a estreita relação entre energia e trabalho mecânico, o indivíduo $\mathrm{C}$ demonstra uma concepção de energia como produto ou substância produzido por um corpo.

Fica claro, então, que a concepção de energia subjacente à prática do professor e ao material didático utilizado como apoio das aulas de física conduziram os alunos a manifestarem concepções, em sua maioria, semelhantes sobre este conceito.

As respostas à questão 3 não exploraram os mecanismos através dos quais cada tipo de transformação de energia ocorreria, mas, antes, apenas enumeraram as possibilidades de transformação de energia como, por exemplo, "energia elétrica em energia térmica" e "energia elétrica em luminosa".

\title{
4.4 Intervenção na disciplina de física
}

Os elementos mais frequentes nas estruturas das aulas ministradas pelo professor de física durante o primeiro semestre foram a exposição teórica, a resolução de exercícios numéricos em conjunto com a sala e a proposição de exercícios de aplicação pelos alunos sob a supervisão do professor e do pesquisador.

A exposição teórica, os exercícios resolvidos e propostos eram retirados da apostila adotada, na maioria das vezes, ou muito semelhantes. Alguns dos exercícios propostos pelo professor, como já dissemos, traziam novidades interessantes para apreciação dos alunos. 
Durante o período em que os alunos se concentravam na resolução dos exercícios propostos, individualmente ou em grupos, o pesquisador e o professor colocavam-se à disposição dos alunos para esclarecer qualquer tipo de dúvida ou até mesmo orientar na interpretação dos exercícios e organização dos dados do enunciado.

Dado que a estrutura geral das aulas ministradas pelo professor privilegiava a aprendizagem de definições dos conceitos e a operação com equações em problemas fechados, nos vimos necessitados de criar condições para que novos tipos de interações ocorressem com a finalidade de enriquecer a análise dos processos de ensino e aprendizagem do conceito de energia. Para isso, elaboramos e aplicamos uma Sequência Didática (SD) em conjunto com o professor.

A aplicação da SD não atendia exclusivamente nossas necessidades de pesquisa. Já fazia algum tempo que o professor sugeria que nós elaborássemos conjuntamente um plano de aulas para o segundo semestre a fim de, segundo ele, aproveitar que um estudante de mestrado da área estava disponível na escola, portanto, consideramos que a aplicação da SD atendeu às demandas da escola também.

A SD aplicada abordou o tema da energia nos contextos da mecânica e da termodinâmica em 8 encontros de 50 minutos cada e seu principal objetivo era o de possibilitar uma reflexão centrada no conceito de energia a partir de diferentes aparatos experimentais.

Tabela 2 - Programa da Sequência Didática sobre energia

\begin{tabular}{cl|} 
Data & Tema \\
\hline 25/Set & Apresentação da SD + Pré-teste \\
02/Out & A chama da vela \\
09/Out & Bola na rampa \\
16/Out & Usina Termelétrica \\
23/Out & O pêndulo e o LED \\
30/Out & Sistematização das aulas \\
06/Nov & Matemática e Conservação da Energia \\
13/Nov & Projeto de intervenção + Pós-teste \\
\hline
\end{tabular}

\subsubsection{Pré-teste e considerações iniciais}

Para os fins desta pesquisa, esta SD foi aplicada com a finalidade de suscitar diferentes tipos de interações linguísticas entre professor e alunos - e mesmo entre alunos relativas ao significado do conceito de energia. A SD é aberta com um Pré-teste e fechada com um Pós-teste (ver Tabela 2). Ambos os testes consistem em um conjunto de contextos, representados por figuras, com os quais a energia pode estar associada ou não (ver Figuras 1 e 2) ${ }^{9}$. Os alunos devem indicar os contextos em que faz sentido falar em energia e

$\overline{9}$ O pré-teste aplicado neste trabalho foi retirado de (BARBOSA; BORGES, 2006) com permissão dos autores. 
justificar suas indicações. Ao final da SD, o mesmo teste é devolvido aos alunos - incluindo as respostas fornecidas por eles no início da SD - que fazem as alterações que julgarem pertinentes tantos em suas indicações quanto em suas justificativas. Os resultados nos ajudaram a relacionar aspectos da intervenção com a capacidade dos alunos em identificar a energia em diferentes contextos.

Figura 14 - Pré-teste - Parte I

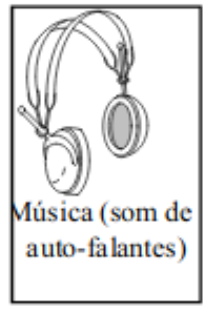

[ ] 1

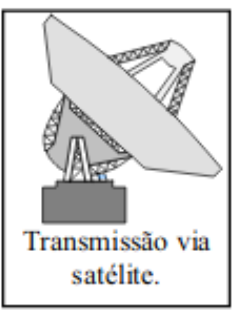

[ ] 2

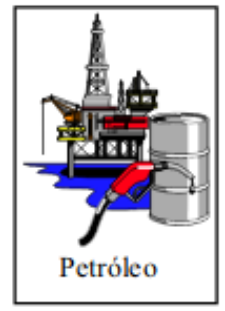

[ ] 3

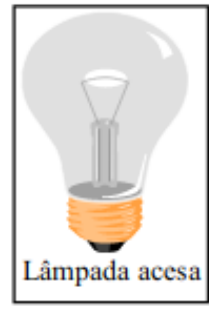

[ ] 4

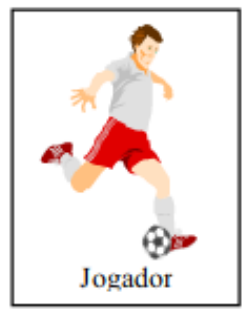

[ ] 5

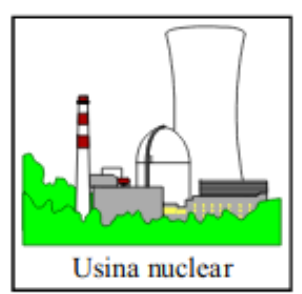

[ ] 6

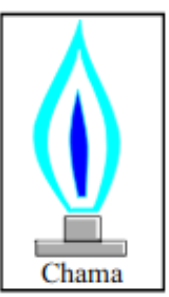

[ ] 7

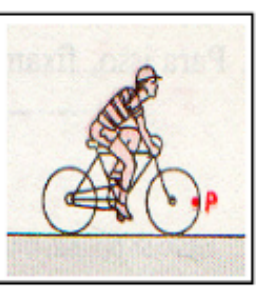

[ ] 8

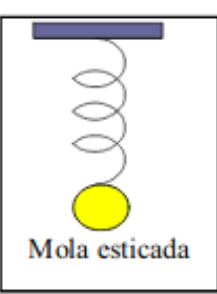

[ ] 9

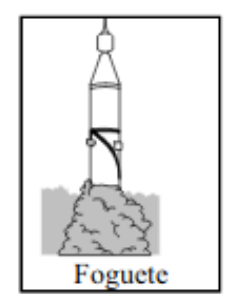

[ ] 10

Figura 15 - Pré-teste - Parte II

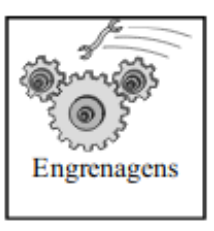

[ ] 11

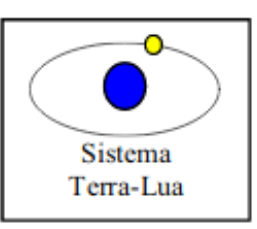

[ ] 12

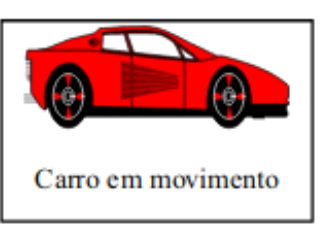

[ ] 13

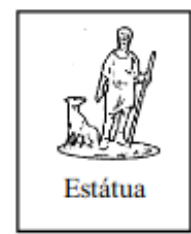

[ ] 14

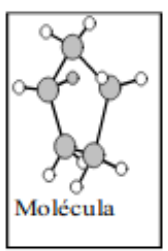

[ ]15

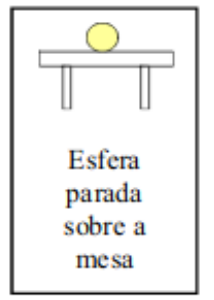

[ ] 16

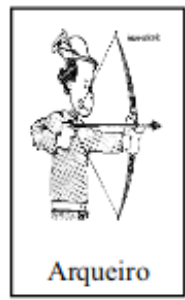

[ ] 17

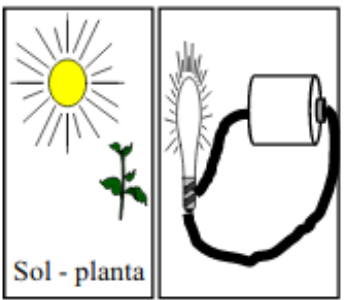

[ ] 18

[ ] 19

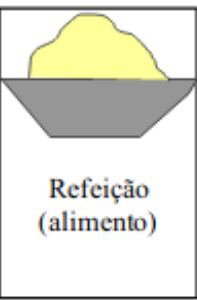

[ ] 20

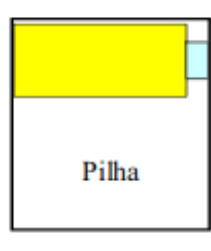

[] 21 
Gráfico 4 - Pré-teste: Relações entre energia e contextos reconhecidas pelos alunos

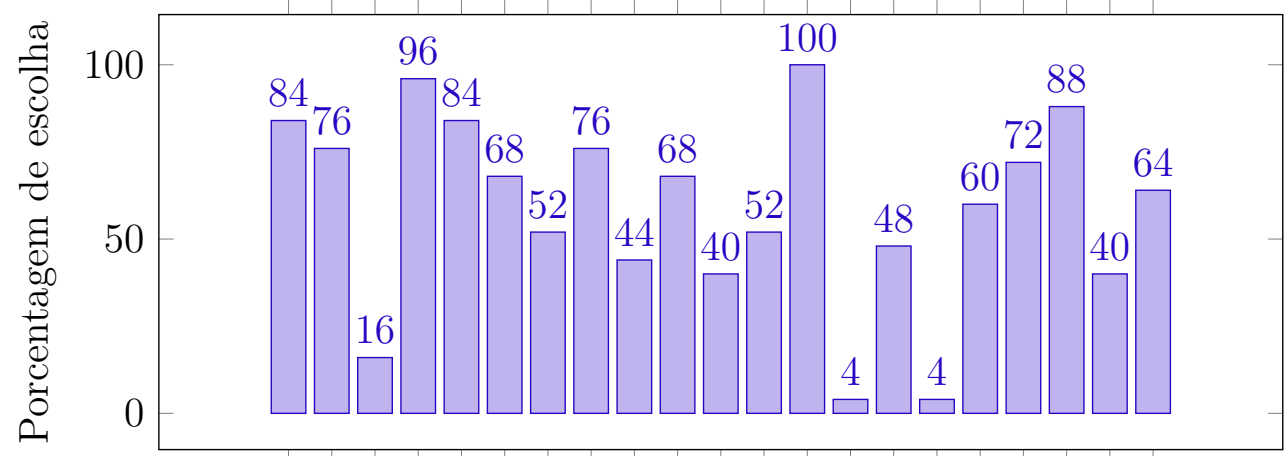

$\begin{array}{llllllllll}1 & 2 & 3 & 4 & 5 & 6 & 7 & 8 & 9 & 101112131415161718192021\end{array}$

Figura

Uma breve análise do gráfico 4 nos permite avaliar em quais contextos os estudantes mais reconhecem a presença de energia. A maior parte dos contextos obtiveram um índice de escolha entre $38 \%$ e $81 \%{ }^{10}, 5$ dos 21 contextos obtiveram índices superiores a $81 \%$ e apenas 3 dos 21 contextos obtiveram índices inferiores a $38 \%$.

Com a finalidade de mapear a imagem dominante do conceito de energia entre os estudantes, em contraste com os aspectos menos considerados do conceito, elencaremos os contextos que se destacaram pelos altos ou baixos índices de escolha em relação à distribuição como um todo. Os contextos mais escolhidos pelos estudantes são, na ordem do mais para o menos escolhido, os representados pelas figuras 13 (carro em movimento), 4 (lâmpada acesa), 19 (circuito elétrico com lâmpada), 1 (Som de auto-falantes) e 5 (Jogador) enquanto que os contextos menos escolhidos são, na ordem do menos para o mais escolhido, os representados pelos números 14 (estátua), 16 (Esfera parada sobre a mesa) e 3 (Petróleo).

Os dados do pré-teste sugerem que as concepções de energia dos estudantes estão mais fortemente associadas aos contextos de movimento e eletricidade enquanto que os aspectos do conceito de energia menos considerados parecem ser aqueles que estão associados com energias potenciais gravitacional, elástica e química. Por outro lado, é possível que os itens 14 e 16 tenham sido pouco escolhidos não apenas pela pouca familiaridade dos estudantes com as formas de energia potenciais mas, sobretudo, por representarem antíteses das situações que envolvem o movimento de corpos.

É interessante notar que a aplicação de nosso pré-teste reproduz um cenário aproximado ao encontrado por Barbosa e Borges (2006) e corrobora as informações apresentadas em breve resumo bibliográfico de Assis e Teixeira (2003) e obtidas através de nossa análise das coleções de livros didáticos, Pietrocola et al. (2013) e Kantor et al. (2013), anteriormente apresentada.

A relação entre os dados obtidos em situações particulares e as conclusões tiradas

10 Intervalo estabelecido pela média e desvio padrão da distribuição. 
a partir do estudo de diversas situações de ensino de ciências, como é o caso do trabalho de Assis e Teixeira (2003) e da análise das coleções de livros aprovadas pelo PNLD 2015, sugerem que o cenário encontrado em nossa situação de pesquisa possa corresponder, em algum grau, ao cenário mais geral do ensino do conceito de energia. Assim, os aspectos privilegiados ou negligenciados do conceito de energia podem ser os mesmos em diversas situações de ensino diferentes.

Os temas de nossa SD foram selecionados com a finalidade de proporcionar maior capacidade de reconhecer a relevância da energia em contextos similares aos representados pelos figuras de números 3, 14 e 16 diminuindo, assim, as chances de que uma visão dogmática do conceito de energia se consolide entre os estudantes.

\subsubsection{Diálogos sobre o significado do conceito de energia e sobre a transfor- mação de energia em uma usina termo-elétrica}

Apresentamos, a seguir, os significados das siglas utilizadas ao longo dos diálogos:

$$
\begin{gathered}
\mathrm{PR}=\text { Professor responsável pela turma. } \\
\mathrm{PQ}=\text { Pesquisador e autor da dissertação. }
\end{gathered}
$$

Letras de $\mathrm{A}$ até $\mathrm{E}=$ Estudantes identificados sobre os quais foi possível aprofundar nossas análises.

Letras de $\mathrm{R}$ até $\mathrm{Z}$ = Estudantes identificados sobre os quais não foi possível aprofundar nossas análises.

$$
\begin{gathered}
\mathrm{NI}=\text { Estudante não identificado. } \\
\text { MT }=\text { Muitos estudantes. }
\end{gathered}
$$

$\mathrm{VR}$ ou $\mathrm{AL}=$ Alguns estudantes ou vários estudantes.

Selecionamos trechos de alguns diálogos que ocorreram durante dois encontros da SD, a saber, um sobre a chama da vela e o outro sobre a usina termelétrica onde, acreditamos, ocorreram as interações mais interessantes para os objetivos deste trabalho.

Este primeiro encontro foi organizado em dois momentos principais: um para discutir o significado da palavra energia e o outro para refletir sobre de que maneira a energia estava presente em uma vela acesa. No início do encontro, o pesquisador ${ }^{11}$ acendeu uma vela e a deixou no centro da classe de forma que todos os alunos pudessem observá-la e, enquanto isso, iniciou uma discussão com a pergunta "O que é energia?":

\footnotetext{
11 Na descrição e análise dos diálogos utilizaremos o termo pesquisador para fazer referência ao autor desta dissertação e professor para fazer referência ao professor responsável pela disciplina de física da turma observada.
} 
Tabela 3 - Diálogo sobre o significado de energia

\begin{tabular}{cl} 
Sujeito & Fala \\
\hline PQ & A vela está acesa ali. Eu não vou entrar nesse assunto agora. Ela só vai \\
& ficar ali e, no finalzinho da aula, a gente vai falar dela. Por enquanto, eu \\
& queria saber quem quer arriscar uma definição de energia. Quem quiser \\
& falar o que é energia é só levantar a mão. \\
E & Energia é uma força maior que tem a qualidade de realizar trabalho. \\
Z & Energia térmica! \\
PQ & É algo que tem a capacidade de realizar trabalho? \\
E & É. \\
PQ & Então, segundo a E é algo que pode realizar trabalho. Beleza. Quem mais \\
& quer falar alguma coisa? Fala Z. \\
E & Ele falou que isso pra ele é Deus. \\
Z & Energia é aquilo que tem força para se mover. Energia também não pode \\
& ser inventada nem exterminada. \\
PQ & Tá. Então o Z falou duas coisas. A primeira coisa que o Z falou é que \\
& energia é aquilo que tem força para se mover? (Olha para o aluno a fim \\
Z & de confirmar) \\
PQ & E a outra, é que energia não pode ser criada e nem pode acabar. \\
Z & Só corrigindo. Ela não surge do nada. \\
PQ & Ela não surge do nada. Quem mais? Beleza, Ele corrigiu. Não pode surgir \\
& do nada.
\end{tabular}

É interessante notar que a primeira resposta à pergunta, do indivíduo E, é a definição do conceito de energia fornecida pela apostila adotada pelo professor durante o primeiro semestre e que o indivíduo $\mathrm{Z}$ enuncia o princípio de conservação da energia, também discutido durante o primeiro semestre. Além disso, o termo energia é associado a outros termos como, por exemplo, trabalho, força e movimento. Os principais tipos de energia presentes no diálogo são energia cinética e térmica.

Em seguida, o pesquisador solicita que os alunos pensem em diferentes tipos de energia (Tabela 4) e obtém uma lista dos tipos de energia conhecidos pela turma: 
Tabela 4 - Diálogo sobre os tipos de energia

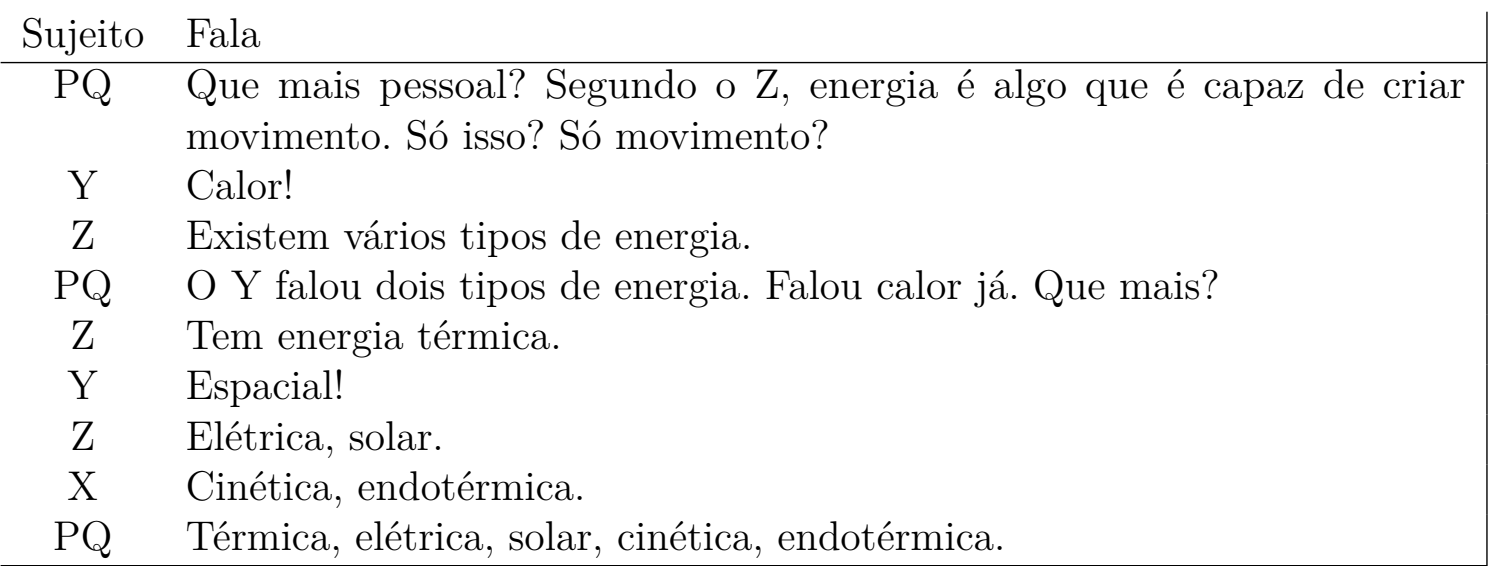

Os tipos de energia citados pelos alunos são térmica, espacial, elétrica, solar, cinética e endotérmica. Destacamos o fato de que os termos "espacial" e "solar" não pertencem ao mesmo conjunto dos demais termos por representarem ideias diferentes. Enquanto "espacial" deve ter sido fruto de alguma confusão do indivíduo Y, "solar" diz respeito à fonte de energia, o sol, mas que é energia na forma de radiação.

Em suma, os tipos de energia citados foram cinética, térmica e elétrica que são os tipos com maiores números de ocorrências nas coleções de livros didáticos analisadas anteriormente.

Com a finalidade de introduzir alguns tipos de energias potenciais na discussão, o pesquisador chama a atenção para uma caixinha de fósforos deixada ao lado da vela acesa, sobre a mesa, e pergunta se esta caixinha possui energia ao que os alunos respondem expressando uma concepção de energia como ente armazenado dentro dos corpos: 
Tabela 5 - Diálogo sobre energia como ente armazenado em um corpo.

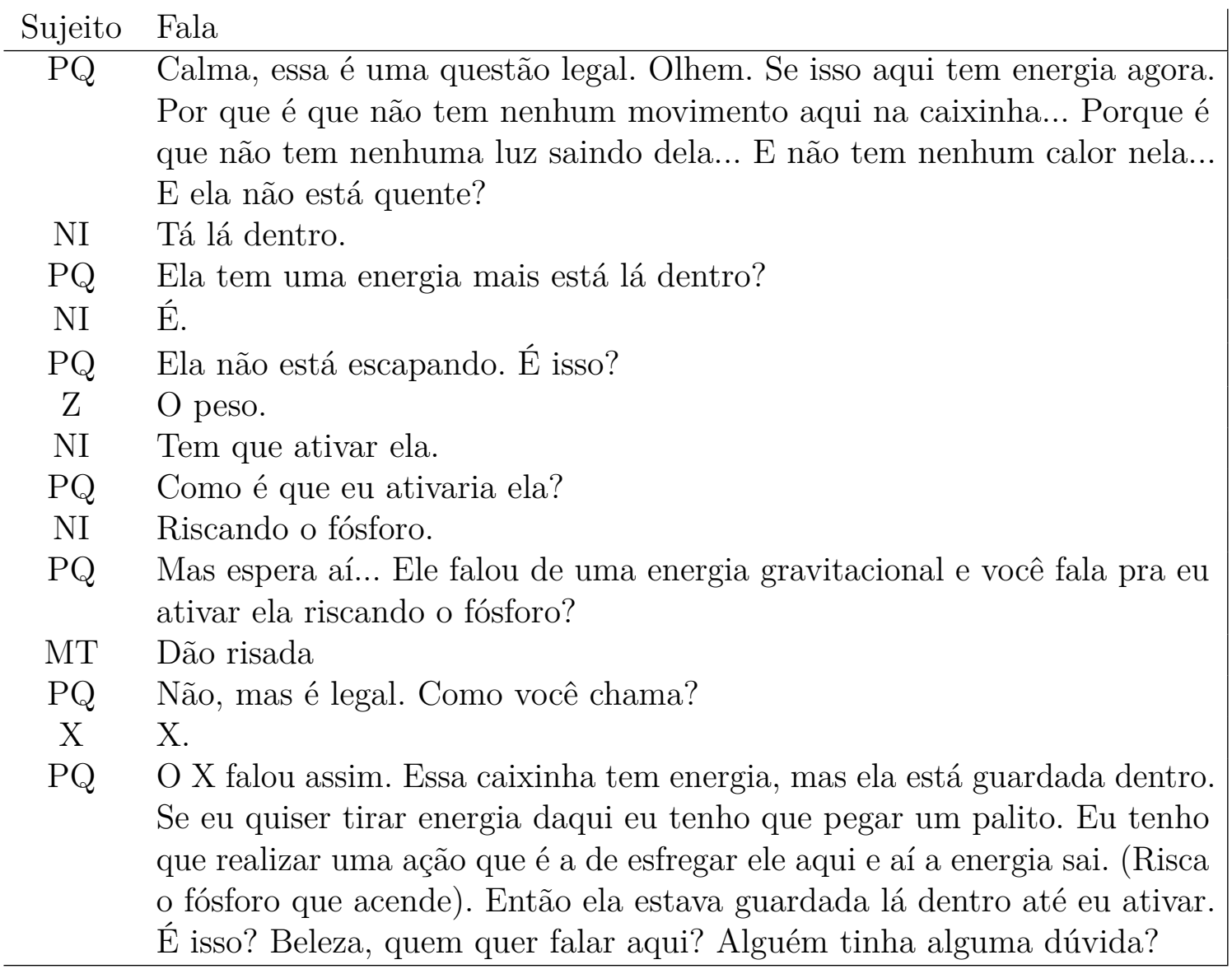

Em resposta à pergunta "Essa caixinha possui energia?" os alunos dão dois direcionamentos relacionados com a energia potencial gravitacional do sistema caixinha de fósforo - planeta Terra e com a energia potencial química das moléculas dos materiais constituintes do fósforo que, quando atritados, permitem que este acenda.

A identificação da energia potencial química do fósforo se dá pela concepção de que há algo dentro do palito de fósforo que é energia e precisa ser liberado ou ativado por meio de ação externa o que, de certa forma, representa bem a situação. Enquanto isso, o indivíduo $\mathrm{Z}$ associa a energia da caixinha de fósforos ao seu peso e a possibilidade de que esta caia da mesa, entrando em movimento.

É interessante notar que, aparentemente, essas formas de energias potenciais somente são reconhecidas como energia porque, na visão dos alunos, trazem em si a possibilidade de se tornarem calor ou movimento que são formas de energia já reconhecidas por eles. 
Tabela 6 - Relação entre energia e movimento como obstáculo.

\begin{tabular}{|c|c|}
\hline Sujeito & Fala \\
\hline PQ & $\begin{array}{l}\text { Beleza galera. Então tem uma energia que tá dentro. Ela não estava } \\
\text { aparecendo (fala enquanto segura o palito de fósforo aceso). Todo mundo } \\
\text { concorda com isso ou acha que é uma ideia... Ninguém discorda? }\end{array}$ \\
\hline $\mathrm{Z}$ & Eu não entendi. \\
\hline PQ & $\begin{array}{l}\text { O X. Ele falou que tem... Que aquela caixinha tem uma energia mas } \\
\text { eu não percebo nenhuma (modificação) ao redor dela porque ela está } \\
\text { guardada dentro. É uma energia guardada. }\end{array}$ \\
\hline $\mathrm{D}$ & Quê!? \\
\hline PQ & Ele que falou. Vocês podem discordar. \\
\hline NI & Eu não entendi nada. \\
\hline $\mathrm{D}$ & $\begin{array}{l}\text { Eu discordo. Como que tem energia se não tem movimento nenhum? Não } \\
\text { faz sentido... }\end{array}$ \\
\hline PQ & $\begin{array}{l}\text { É justamente isso. É apenas uma caixa parada e alguém está defendendo } \\
\text { que ela tem energia. Eu quero entender o motivo. }\end{array}$ \\
\hline
\end{tabular}

Os indivíduos $\mathrm{D}$ e $\mathrm{Z}$ apresentam dificuldade em compreender a ideia de energia potencial química contida na caixinha de fósforos, sendo que um dos indivíduos é o proponente da ideia de energia potencial gravitacional relacionando a energia com o peso. Para o indivíduo D, parece ser inconcebível atribuir energia à situações em que não há movimento. Verificando as respostas do indivíduo D ao pré-teste constatamos a seleção dos itens de números 4, 5, 6, 7, 8, 9, 11, 13 e 17 onde, de fato, há predominância de situações que apresentam movimento mas também outros tipos de situações: 4 (Lâmpada acesa), 6 (Usina nuclear) e 7 (chama).

Temos aqui um exemplo interessante do que uma determinada imagem de um conceito pode ocasionar nos indivíduos: a incapacidade de reconhecer diferentes situações de aplicação do conceito segundo diferentes regras gramaticais. Para o indivíduo que possui uma concepção dogmática de energia, como a de que somente há energia quando há movimento, os demais usos previstos pela gramática do conceito não são reconhecidos como possíveis e, portanto, não só ocasiona a restrição dos usos deste conceito como, em consequência, oferece um obstáculo à análise de diversas situações em termos energéticos. 
Tabela 7 - O papel da persuasão na formação da gramática do conceito de energia.

\begin{tabular}{cl} 
Sujeito & Fala \\
\hline PQ & Galera, o que que acontece se eu empurrar essa caixinha aqui? (Empurra \\
& a caixinha até a borda da mesa, derrubando-a). \\
MT & Vai cair! \\
PQ & Por que que ela cai? \\
Z & Peso. \\
PQ & Tem peso. O peso é de quem? \\
Z & Da caixinha. \\
PQ & O peso da caixinha. Foi ela que caiu ou eu quem jogou ela no chão? \\
MT & Você que jogou. \\
PQ & Eu que joguei? Vê bem se eu tô jogando ela no chão. Olha aí... Dá uma \\
& olhada. Vê se eu vou jogar ou se eu vou só soltar. (Suspende a caixinha e \\
& a solta diante de todos os alunos) \\
MT & Soltou. \\
PQ & Então ela caiu ou eu joguei ela? \\
MT & Ela caiu. \\
PQ & Pra eu jogar a caixinha eu teria que imprimir uma força nela. Beleza, \\
& então eu só soltei e ela caiu. Então, a energia que ela recebe pra cair não \\
& veio de mim. Porque eu só solto. Da onde que vem a energia da queda \\
MT & dela? \\
PQ gravidade. & Mas essa energia já está aqui ou ela aparece somente quando eu solto? \\
Z & Quando você solta. \\
PQ & Não! Ela já está aqui. \\
Z & Ah sim! Sim! \\
W & Ela só não está caindo agora porque tem uma força contrária, da sua mão, \\
& segurando ela.
\end{tabular}

Neste trecho, a queda da caixa de fósforos é associada ao seu peso, ou seja, a energia percebida através da queda da caixa teria origem na gravidade ou, segundo o indivíduo Z, no peso da caixa de fósforos. O pesquisador empurra a caixa de fósforos até a borda da mesa, em um movimento horizontal, enquanto dirige à turma a seguinte pergunta: o que acontece se eu empurrar essa caixinha aqui? Boa parte dos alunos da turma responde que ela irá cair e, poucos instantes depois, ela cai descrevendo um movimento vertical. O pesquisador sonda a opinião dos alunos sobre seu papel na queda da caixinha e os alunos atribuem a queda à ação do pesquisador. Logo em seguida, o pesquisador pergunta "Eu que joguei? Vê bem se eu tô jogando ela no chão. Olha aí... Dá uma olhada. Vê se eu vou jogar ou se eu vou só soltar", suspende a caixinha diante dos alunos mantendo-a parada à mesma altura e, então, abre os dedos das mãos deixando que a mesma caia livremente. Os alunos respondem que o pesquisador apenas soltou, e não jogou, a caixa de fósforos.

Podemos observar que os alunos veem a ação do pesquisador de empurrar a caixa de fósforos horizontalmente até a borda da mesa como responsável pela queda da mesma. 
O pesquisador reformula sua demonstração suspendendo a caixinha no ar em vez de empurrá-la sobre a superfície da mesa conseguindo, assim, evidenciar que a caixa cai sem que ele precise imprimir alguma força de cima para baixo, ou seja, apenas soltando-a. No entanto, a reformulação da situação que desencadearia a queda da caixa de fósforos não é o único elemento que contribui com a nova resposta fornecida pelos alunos. A própria escolha do pesquisador de repetir e reformular a pergunta oferecendo, inclusive, uma alternativa à resposta anteriormente fornecida pelos alunos já dá indícios de que sua intenção era a de que os alunos respondessem justamente com a alternativa fornecida.

Esse conjunto de ações fornece uma nova forma de ver a queda, diferente da forma cotidiana em que seria completamente plausível dizer que alguém jogou a caixinha no chão ao agir como o pesquisador em qualquer das duas situações. Esta nova forma de ver a queda contribui para que os alunos sejam capazes de distinguir entre as situações em que há queda livre, originada a partir da interação entre corpo e planeta Terra, e em que há arremesso, originada a partir de um agente externo ao sistema corpo-planeta que imprime uma força a um corpo que interage com um campo gravitacional.

Para que os alunos possam avançar nestas etapas de compreensão é necessário que os mesmos aceitem essa forma de ver a queda. Como não se trata de uma questão de convencimento a partir de premissas, mas da formulação de um novo conjunto de premissas, dizemos que se trata de um processo de persuasão, em que as regras constituintes da gramática do conceito de energia são assimiladas e aceitas pelos alunos ${ }^{12}$. Wittgenstein (2010a) reflete sobre o papel das crenças no aprendizado:

Geralmente eu dou como verdadeiro aquilo que encontro em livrostextos, de geografia por exemplo. Por quê? Eu digo: Todos estes fatos foram confirmados mais de cem vezes. Mas como eu sei disso? Quais minhas evidências para isso? Eu tenho uma imagem de mundo. Isto é verdadeiro ou falso? Acima de tudo isso está o substrato de todos os meus questionamentos e afirmações. As proposições que descrevem isto não são todas igualmente sujeitas a testes (WITTGENSTEIN, 2010a, § 162).

Da mesma maneira que, geralmente, acreditamos nas informações fornecidas por livros didáticos das diversas disciplinas escolares, aceitamos uma série da convenções propostas por nossos professores durante o período de formação. Estas convenções, longe de serem passiveis de verificação, são elementos constitutivos da gramática dos conceitos da disciplina ${ }^{13}$. A partir desta gramática, desta imagem de mundo, é que os estudantes

12 Adotamos convencimento como o processo de mostrar a necessidade de uma afirmação através de um processo lógico que parte de um conjunto de premissas enquanto compreendemos a persuasão como o processo de convencer o interlocutor a abandonar seu sistema de crenças (suas premissas) e substituí-lo por outro

13 Vale ressaltar que, em diferentes contextos, as mesmas proposições podem ser usadas ora como normativas, como constituintes da gramática, e ora como descritivas, como proposições empíricas (apoiadas em uma gramática) passíveis de verificação. 
poderão formular hipóteses ou proposições passíveis de verificação.

Por fim, o pesquisador afirma - em confronto com a resposta do indivíduo Z - que a energia já está presente na caixa de fósforos suspensa mesmo antes que esta seja solta e - com o auxílio do indivíduo W - que sua mão segurando a caixa apenas impede que a energia potencial gravitacional presente se transforme em energia cinética através da queda livre do corpo.

Estas afirmações, sustentadas mesmo em confronto com os alunos e dispensando um processo de reflexão ou investigação prévio constituem aos poucos a gramática do conceito de energia, ou seja, o sistema de proposições de caráter convencional que possibilitará a aplicação deste conceito em diversas situações posteriores, incluindo situações de investigação onde modelos e proposições (empíricas) deverão corresponder ao mundo físico. Claro que se pode refletir sobre as razões destas convenções a partir de seu poder descritivo ou preditivo, mas não cabe querer justificá-las a partir da experiência empírica, uma vez que, em nossa visão, são justamente essas convenções que possibilitam uma determinada experiência do mundo físico. Nesta etapa do ensino estão sendo estabelecidos os critérios de ligação entre linguagem e mundo ou, de outra forma, os objetos do mundo estão sendo incorporados à linguagem com sentido.

O pesquisador inicia uma discussão com a finalidade de chamar a atenção para a energia potencial gravitacional e química. 
Tabela 8 - Diálogo sobre conservação da energia mecânica - Parte I.

\begin{tabular}{|c|c|}
\hline Sujeito & Fala \\
\hline PQ & $\begin{array}{l}\text { A cinética é ela já se movendo. Essa energia aqui, agora, é cinética. (Solta } \\
\text { a caixinha do alto e aponta enquanto ela cai). Essa energia que está aqui, } \\
\text { que eu não estou vendo, como é que chama? (Suspende a caixa de fósforos } \\
\text { diante dos alunos). }\end{array}$ \\
\hline $\mathrm{D}$ & Cinética. \\
\hline PQ & Não é cinética! \\
\hline $\mathrm{E}$ & Assintética. \\
\hline MT & (Fazem tentativas inaudíveis). \\
\hline $\mathrm{PQ}$ & Galera, chama energia... (pausa) Potencial. \\
\hline MT & Potencial! \\
\hline $\mathrm{E}$ & Eu ia falar. Mas não falei. \\
\hline PQ & $\begin{array}{l}\text { O quê que você entende seu eu falo "Cara você tem um enorme potencial } \\
\text { profissional!"? Que que eu quero dizer com isso? }\end{array}$ \\
\hline MT & (Inaudível). \\
\hline $\mathrm{PQ}$ & $\begin{array}{l}\text { Que você pode ser um grande profissional. Você é um grande profissional } \\
\text { agora? }\end{array}$ \\
\hline $\mathrm{D}$ & Sim. \\
\hline PQ & $\begin{array}{l}\text { Se eu disser que você tem um grande potencial eu não estou falando } \\
\text { que você já é um grande profissional. Estou falando que você pode vir a } \\
\text { ser. Galera, a energia potencial da caixinha é porque ela pode adquirir } \\
\text { movimento. Ela tem isso dentro dela. Ela pode adquirir movimento mas } \\
\text { ela só vai adquirir se eu soltar. Beleza? Tem outros tipos de energias } \\
\text { potenciais. Por exemplo, a que o X citou. }\end{array}$ \\
\hline PQ & $\begin{array}{l}\text { Nesse fósforo aqui tem uma energia potencial no elemento químico que } \\
\text { constitui a ponta dele. (Retira um palito de fósforo da caixa). Pra ela } \\
\text { ser liberada, essa energia que aquece e ilumina, eu tenho que friccionar } \\
\text { contra esse outro material aqui. Mas a energia já está aqui. Tanto que não } \\
\text { basta que eu friccione. Se eu pegar a parte que não tem nada do palito } \\
\text { e friccionar, não acontece nada. Tudo bem? A energia já está aqui. Eu } \\
\text { preciso de um gatilho para ela sair da potência e ir para o ato. Do que } \\
\text { pode acontecer para o que acontece de fato. }\end{array}$ \\
\hline $\mathrm{E}$ & Inaudível. \\
\hline PQ & $\begin{array}{l}\text { Energia potencial, devido à gravidade, e energia cinética. Movimento. } \\
\text { (Suspende e depois solta a caixinha). }\end{array}$ \\
\hline PQ & $\begin{array}{l}\text { Energia potencial química, devido a as moléculas pontinha do fósforo, e } \\
\text { energia térmica e energia luminosa em ato. (Risca o fósforo acendendo-o). } \\
\text { Não é mais potencial. Potencial é, poderia gerar fogo e poderia gerar } \\
\text { calor e luminosidade. Aqui já está em ato, acontecendo. Então olha só. } \\
\text { Que energia que tem aqui, nesse momento? (Ergue a caixinha diante de } \\
\text { todos). }\end{array}$ \\
\hline MT & Potencial! \\
\hline
\end{tabular}


O pesquisador esclarece os conceitos de energia em potência e energia em ato oferecendo dois exemplos, a saber, a caixa de fósforos suspensa que ao ser solta adquire velocidade conforme evolui em queda livre e o palito de fósforo que ao ser riscado consomese em chamas. Em ambas as situações o pesquisador faz referência ao próprio fenômeno enquanto diz as palavras "potência" e "ato" de forma que as situações apresentadas tornam-se paradigmas de energia potencial e energia em ato, seja esta térmica ou cinética.

Na tentativa de ensinar a concepção de energia potencial para os estudantes o pesquisador faz uma afirmação que reforça uma imagem do conceito de energia que este trabalho visa combater, a saber, a imagem de energia como ente armazenado dentro de um corpo. Nos referimos à afirmação "Ela tem isso dentro dela". Há duas importantes reflexões que podemos tirar deste episódio. Por um lado, percebemos o quanto pode ser difícil a tarefa de produzir um discurso pedagógico que não incorra nos vícios de determinada área mesmo quando o professor está consciente destes vícios e tomou a decisão de combatê-los. Por outro, podemos reconhecer o caráter positivo das imagens que constituem os conceitos científicos e suas relações no decorrer da atividade de ensino.

A terapia filosófica que buscamos fazer sobre o ensino do conceito de energia no contexto escolar não visa eliminar o uso das diversas imagens deste conceito do ensino de ciências mas evitar que uma ou pouca dessas imagens sejam privilegiadas em detrimento de outras igualmente legítimas. As imagens surgem dos usos que fazemos de nossos conceitos e, por isso, são inevitáveis e, até mesmo, necessárias. O dogmatismo é o resultado do reconhecimento de apenas uma ou poucas destas imagens como legítimas.

Em seguida, o pesquisador procura enfatizar que transformação da energia potencial gravitacional em cinética se dá progressivamente ao longo da queda da caixa de fósforos. Para isso, analisa as diferentes formas de energia encontradas ao longo da queda, com o objeto em diferentes alturas e velocidades. 
Tabela 9 - Diálogo sobre conservação da energia mecânica - Parte II.

\begin{tabular}{|c|c|}
\hline Sujeito & Fala \\
\hline PQ & Potencial devido à gravidade e por isso é potencial gravitacional. \\
\hline $\mathrm{PQ}$ & $\begin{array}{l}\text { Soltei, no meio do caminho tem o quê? (Segura a caixa de fósforos em } \\
\text { uma altura menor que a anterior). }\end{array}$ \\
\hline $\mathrm{E}$ & Potencial. \\
\hline Z & Cinética. \\
\hline MT & Cinética. \\
\hline $\mathrm{PQ}$ & $\begin{array}{l}\text { Tem cinética, com certeza, porque está em movimento. E depois que } \\
\text { chega lá embaixo? }\end{array}$ \\
\hline NI & Energia potencial. \\
\hline PQ & $\begin{array}{l}\text { Vamos pensar assim ó... Aqui tem energia potencial? (Levanta a caixa de } \\
\text { fósforos ao máximo que consegue). }\end{array}$ \\
\hline NI & Tem. \\
\hline $\mathrm{Z}$ & Tem. \\
\hline $\mathrm{PQ}$ & e aqui? (Reduz a altura da caixa em alguns centímetros). \\
\hline NI & Tem. \\
\hline $\mathrm{PQ}$ & E aqui? (Reduz mais um pouco a altura). \\
\hline NI & Tem. \\
\hline $\mathrm{PQ}$ & E aqui? (Reduz mais um pouco). \\
\hline NI & Tem. \\
\hline PQ & E aqui? (Reduz mais um pouco). \\
\hline $\mathrm{Z}$ e $\mathrm{C}$ & Tem. \\
\hline $\mathrm{PQ}$ & Aqui, no chão, tem energia potencial? (Encosta a caixinha no chão). \\
\hline \multicolumn{2}{|l|}{ MT } \\
\hline $\mathrm{T}$ & PQ, é a mesma de cima porque estava assim, parado. \\
\hline PQ & $\begin{array}{l}\text { Tudo bem. Aqui ela é potencial porque ela pode vir a adquirir movimento } \\
\text { (Suspende a caixinha à uma altura intermediária). Quando ela está no } \\
\text { chão, no nível mais baixo, ela pode vir a adquirir movimento? }\end{array}$ \\
\hline E e Z & Não. \\
\hline $\mathrm{PQ}$ & Não tem como ela cair mais do que isso. Né? \\
\hline $\mathrm{D}$ & Só se você chutar ela! \\
\hline PQ & $\begin{array}{l}\text { Olha só. Pessoal, se aqui tem potencial (Segura a caixa na altura máxima). } \\
\text { E aqui também tem (Segura a caixa em uma altura intermediária). Quando } \\
\text { eu solto ela (Solta a caixa da altura máxima e a segura com a outra mão } \\
\text { em uma altura menor). Quando ela esta aqui nesta posição caindo (Indica } \\
\text { a caixinha com o indicador da mão direita enquanto move a caixinha } \\
\text { para baixo com a mão esquerda). Ela tem duas energias! Tem a potencial, } \\
\text { porque está nessa altura, e tem a cinética porque já tem movimento. } \\
\text { Agora, o que que vai acontecendo? (Diminui a altura da caixa de fósforos } \\
\text { progressivamente). Essa energia potencial vai diminuindo porque a altura } \\
\text { vai diminuindo e a energia cinética vai aumentando porque a velocidade } \\
\text { vai aumentando. Então olha, diminui energia potencial e aumenta energia } \\
\text { cinética. No chão, o que que acontece? }\end{array}$ \\
\hline $\mathrm{D}$ & Não tem energia cinética nem potencial. \\
\hline
\end{tabular}


Durante todo esse diálogo, o professor apresenta a caixa de fósforo suspensa em diferentes alturas com relação ao chão da sala de aula, simula a queda livre de maneira controlada e analisa a variação da energia cinética e potencial gravitacional em diversos pontos da trajetória da queda. Essa sequência de ações e interações com a turma constituem um treinamento que capacita os alunos a reconhecerem a presença de um tipo de energia exclusivamente pela altura que um corpo apresenta em relação ao solo. O resultado deste treinamento é o aumento da capacidade dos alunos em reconhecer a presença de energia, e portanto aplicar o conceito, em situações em que um corpo está à determinada altura do solo e não somente aquelas em que há movimento.

Além disso, por meio da demonstração da queda da caixa de fósforos é feita uma correlação entre a variação da energia potencial gravitacional e a energia cinética do corpo em queda livre. Enquanto a energia potencial gravitacional diminui durante a queda, a energia cinética aumenta. Essa compreensão pode ser um primeiro passo para a apresentação da conservação da energia mecânica, incluindo também a energia potencial elástica.

É interessante que o indivíduo D fecha esta parte do diálogo afirmando corretamente que no final da queda livre, quando a caixa está no chão, não há mais energia cinética e nem energia potencial gravitacional, sem estranhar a não conservação da energia mecânica. Estranhamos sua naturalidade porque a temática da conservação da energia mecânica na queda livre havia sido razoavelmente discutida durante o primeiro semestre com o professor responsável da turma e, invariavelmente, os corpos em queda livre apresentavam a energia cinética máxima no nível do solo, energia que correspondia à energia potencial gravitacional da situação inicial. No entanto, podemos compreender sua conclusão uma vez que a linha de raciocínio proposta pelo pesquisador tenha associado fortemente a energia cinética ao movimento e a energia potencial gravitacional à altura de forma que, ao observar a caixinha sem altura e em repouso, tal conclusão decorra naturalmente. Problematizando esta conclusão, o pesquisador continua: 
Tabela 10 - Diálogo sobre conservação da energia mecânica - Parte III.

\begin{tabular}{|c|c|}
\hline jeito & Tala \\
\hline PQ & $\begin{array}{l}\text { Depois de bater, você já não tem mais energia potencial nem cinética. } \\
\text { Porque ela está parada e porque ela não tem altura. Mas pensem um } \\
\text { segundo antes dela bater no chão... Um instantinho antes. Que energia } \\
\text { que ela tem? }\end{array}$ \\
\hline $\mathrm{D}$ & Cinética! \\
\hline PQ & $\begin{array}{l}\text { Ela tem toda a energia potencial transformada em cinética! Toda! Porque } \\
\text { não tem mais altura nenhuma do chão... }\end{array}$ \\
\hline $\mathrm{Z}$ & Nossa... Ah sim. \\
\hline PQ & $\begin{array}{l}\text { Então tudo o que era potencial gravitacional virou velocidade, de fato. } \\
\text { Aí, quando ela bate, pra onde que vai essa energia? } \\
\text { (Silêncio) }\end{array}$ \\
\hline NI & Pro chão? \\
\hline PQ & $\begin{array}{l}\text { Olha, potencial (Ergue a caixa na altura máxima). Potencial e cinética } \\
\text { (Reduz a altura da caixa mantendo-a em movimento para baixo), cinética... } \\
\text { (Aproxima do chão sem tocá-lo). E agora? (Deixa a caixinha no chão). } \\
\text { Ela tem zero! Pra onde que foi a energia? } \\
\text { (Silêncio) }\end{array}$ \\
\hline PQ & $\begin{array}{l}\text { Então, todo mundo fecha o olho. Fecha aí... Vocês vão me falar quando } \\
\text { tem energia escapando da caixinha de fósforo. Não vale olhar, feche o olho } \\
\text { aí. Vou fechar também e vocês vão sentir... Quando a energia escapar, } \\
\text { você fala "Agora!". (Solta a caixa de fósforos do alto) }\end{array}$ \\
\hline $\mathrm{Z}$ & Agora! (Diz no instante em que a mesma se choca com o chão) \\
\hline PQ & Opa, como é que você sabe? \\
\hline MT & Barulho! \\
\hline PQ & $\begin{array}{l}\text { Pelo barulho. A energia potencial vira cinética, quando chega no chão } \\
\text { bate, some a energia dela mas vira som. Som é energia! }\end{array}$ \\
\hline
\end{tabular}

Neste trecho do diálogo, o pesquisador conclui que um instante antes de a caixa se chocar contra o chão toda a energia potencial que a mesma tinha por conta de sua altura relativa ao chão se transformará em cinética, em velocidade. Além disso, afirma que toda a energia cinética da caixa de fósforos se transformou em som devido ao choque com o chão.

O modelo subjacente às afirmações do pesquisador possuem algumas características específicas que não foram explicitadas aos alunos e, portanto, acabam contribuindo para a afirmação de certos pressupostos de maneira implícita. Uma dessas características do modelo é a de que a caixa não sofre ação da resistência do ar durante sua queda e, somente por isso, toda sua energia potencial gravitacional é transformada em energia cinética no final do movimento. A outra característica é que também são desprezadas as possíveis transformações da energia cinética da caixa em deformação do material que a constitui e aquecimento dos objetos que se chocaram.

Apesar disso, destacamos a importância destas reflexões visto que frequentemente se confunde a conservação da energia mecânica com o princípio de conservação da energia. 
Além disso, a exploração dos limites de validade do princípio de conservação da energia trazem à tona a necessidade de se discutir que o princípio é valido quando se leva em conta um sistema isolado, ou seja, que não sofre influência de forças externas.

Além disso, a discussão sobre a transformação da energia da caixa em som oferece mais uma forma de ver a energia, a saber, como som. Som é energia!

A seguir, o indivíduo Z questiona a aplicabilidade das afirmações feitas anteriormente para o caso em que o objeto em queda livre fosse uma pena. Provavelmente, o aluno colocou esta questão por entender que se tratava de uma exceção à regra ou um caso especial visto que a pena em queda livre não corresponde com a caixa de fósforos em queda livre em mais de um aspecto, a saber, não descreve uma trajetória retilínea de cima para baixo, não acelera durante toda sua trajetória de queda e, talvez o mais importante para o aluno, não faz barulho ao cair no chão.

Tabela 11 - Diálogo sobre a resistência do ar.

\begin{tabular}{|c|c|}
\hline ujeito & Fala \\
\hline $\mathrm{Z}$ & E se fosse uma pena? \\
\hline PQ & Se fosse uma pena? \\
\hline $\mathrm{AL}$ & É!? \\
\hline PQ & $\begin{array}{l}\text { Pois é... (Faz pausa dramática). Se eu solto uma pena aqui o que acontece } \\
\text { com ela? }\end{array}$ \\
\hline MT & (Falam ao mesmo tempo) \\
\hline PQ & $\begin{array}{l}\text { Ela vai perdendo energia potencial e vai acelerando... Só que ela acelera } \\
\text { até um limite e aí ela cai bem leve no chão e você não escuta. Pra onde } \\
\text { foi a energia? }\end{array}$ \\
\hline $\mathrm{Z}$ & Não sei! \\
\hline $\mathrm{E}$ & Pro ar! \\
\hline PQ & Pro ar! \\
\hline $\mathrm{E}$ & Acertei \\
\hline PQ & $\begin{array}{l}\text { Ela vai descendo e empurrando o ar. Para um lado... E para o outro. } \\
\text { (Simula a pena empurrando o ar com a mão) }\end{array}$ \\
\hline $\mathrm{Z}$ & Ah! Bom. \\
\hline PQ & $\begin{array}{l}\text { Então as moléculas de ar aqui adquirem movimento graças à pena que } \\
\text { está caindo. }\end{array}$ \\
\hline $\mathrm{E}$ & $\begin{array}{l}\text { PQ, mas num lugar sem oxigênio... Um chumbo de uma tonelada e uma } \\
\text { pena caem ao mesmo tempo! }\end{array}$ \\
\hline PQ & $\begin{array}{l}\text { Sem ar. Verdade. E dá para escutar o barulho de uma pena caindo no } \\
\text { vácuo. Se você tem um tubo, que não tem ar dentro, e você solta a pena } \\
\text { ela cai direto, ela cai igual uma pedra... Só que ela é levinha. Então ela } \\
\text { tem pouca energia para transformar em som mas você escuta um "tic"da } \\
\text { peninha caindo. Mas é que é proporcional à massa. Se você jogar uma } \\
\text { coisa mais pesada... As duas chegam junto mas o chumbo faz um barulho } \\
\text { MUITO FORTE e a pena faz um "tiquezinho" de nada. Ao mesmo tempo. }\end{array}$ \\
\hline
\end{tabular}

Entendemos que a formulação desta pergunta revela um certo domínio da gramática 
do conceito de energia no contexto da conservação da energia mecânica na queda livre dos corpos. Apenas assimilando que a energia potencial transforma-se em energia cinética e que esta se transforma em som no final da queda é que um aluno poderia identificar a queda da pena como uma exceção.

O pesquisador compreende a intenção do aluno ao perguntar e devolve a pergunta "Pra onde foi a energia?" e o aluno responde não saber. Em seguida, o indivíduo E diz que a energia de queda da pena vai para o ar e, após a explicação do pesquisador, o indivíduo $\mathrm{Z}$ parece ter compreendido.

A noção de que a energia potencial gravitacional, para o caso da pena, simultaneamente se transforma em energia cinética da pena e das moléculas que compõem o ar ao redor é um aspecto do conceito de energia diferente dos trabalhados até o momento. Se antes a ideia de que a totalidade da energia potencial gravitacional se transformava completamente em cinética era o suficiente para a análise do fenômeno, agora é necessário levar em conta o fluxo de energia do sistema objeto-planeta para outros corpos, as moléculas de ar. Neste caso, a equação de conservação da energia mecânica seria $E_{c 1}+E_{p g 1}+E_{c 2}=k$, onde $E_{c 1}$ é a energia cinética da pena, $E_{c 2}$ é a energia cinética das moléculas de ar, $E_{p g 1}$ é a energia potencial gravitacional da pena e k é uma constante.

Outro aspecto do conceito de energia trabalhado neste diálogo é a relação entre a energia do corpo e sua massa. O pesquisador afirma que se não houvesse ar ao redor da pena a mesma cairia na mesma velocidade que um pedaço de chumbo mas, no entanto, o som produzido por ambos não seriam os mesmos dado que a energia a ser convertida em som é proporcional às massas dos objetos em queda livre. Ou seja, objetos de diferentes massas que se deslocam às mesmas velocidades têm energias diferentes. A equação da energia cinética $E_{c}=\frac{m v^{2}}{2}$ reflete bem esta ideia.

O professor de física da turma fez uma intervenção na aula com a finalidade de discutir o aspecto convencional ${ }^{14}$ do cálculo da energia potencial gravitacional. Para isso, ele colocou uma cadeira sobre uma mesa de forma que todos os alunos pudessem observar e, em seguida, utilizou o apagador para fazer uma pergunta para o pesquisador: "Se esse apagador está aqui na cadeira, ele tem uma energia potencial em relação à mesa. Agora, se ele cair aqui na mesa ele ainda tem energia potencial?":

\footnotetext{
14 Aqui, convencional é aplicado com o sentido de conscientemente escolhido enquanto que em Wittgenstein convencional remete aos aspectos arbitrários de nossa linguagem que, conscientemente ou não, são aceitos e compartilhados por uma forma de vida.
} 
Tabela 12 - O papel da convenção para o cálculo da energia potencial gravitacional.

\begin{tabular}{|c|c|}
\hline jeito & ala \\
\hline PR & $\begin{array}{l}\text { Pera aí que eu vou fazer uma pergunta (Coloca uma cadeira sobre uma } \\
\text { carteira, na frente da classe). Se esse apagador está aqui na cadeira ele } \\
\text { tem uma energia potencial em relação à mesa. Agora, se ele cair aqui na } \\
\text { mesa ele ainda tem energia potencial? (Empurra o apagador até a borda } \\
\text { da cadeira deixando-o cair sobre a mesa) }\end{array}$ \\
\hline PQ & $\begin{array}{l}\text { Tem. Então, a energia potencial depende do referencial... Se eu adotei } \\
\text { esse referencial como zero (indica a altura da superfície da mesa). Então o } \\
\text { apagador tem zero. Mas eu estou adotando o chão (Aponta para o chão)... } \\
\text { Então quando PR me pergunta se ele tem energia potencial agora eu digo } \\
\text { sim porque eu estou adotando o chão como referencial . }\end{array}$ \\
\hline NI & $\begin{array}{l}\text { PQ, Mas e se ele estiver no chão e o chão sumir e ele cair. Fizer um } \\
\text { buraco? }\end{array}$ \\
\hline VR & (Dão risada e tiram sarro) \\
\hline PR & (Concorda com a cabeça enquanto aponta para o aluno) \\
\hline PQ & $\begin{array}{l}\text { Imagina o relevo terrestre, que tem lugares mais altos e mais baixos... } \\
\text { Se você está no chão, e ele é seu referencial, então a energia potencial } \\
\text { é zero... Mas esse chão pode ser o topo de uma montanha e se você vai } \\
\text { até a beirada da montanha e solta algo, ele adquire velocidade. Então, } \\
\text { energia potencial tem lá. Mas, agora, imagina assim: Você tem uma esfera, } \\
\text { o planeta Terra é esférico. Imagine que ela não tem irregularidade. Não é } \\
\text { assim, mas imagine que fosse assim. Que ela seja lisinha (Faz um gesto } \\
\text { imitando o contorno de uma esfera com as duas mãos). Quando você } \\
\text { coloca um objeto aqui em cima dessa esfera (Mantém a mão esquerda como } \\
\text { se representasse a superfície esférica do planeta e indica sua superfície } \\
\text { apontando a própria mão esquerda com a mão direita). Ela tem uma } \\
\text { energia potencial sempre. A distância do objeto até o centro da Terra } \\
\text { fornece pra ele uma energia potencial. Mas é uma energia potencial que } \\
\text { está fadada a ser energia potencial para sempre porque não tem pra onde } \\
\text { ele cair. Ele tem energia potencial mas ele nunca terá como cair mais pra } \\
\text { baixo que o chão. Então é uma energia potencial que fica preza lá e, por } \\
\text { isso, agente não considera. É como se não tivesse. }\end{array}$ \\
\hline PR & Na verdade é uma convenção, né? \\
\hline $\mathrm{PQ}$ & É uma convenção. \\
\hline
\end{tabular}

Entendemos que, com essa pergunta, o professor desejava destacar que a energia potencial gravitacional de um corpo dependia da adoção de um ou outro referencial. Caso nosso referencial fosse a superfície da mesa, a energia potencial gravitacional seria zero. No entanto, se nosso referencial fosse a superfície do chão a energia seria maior que zero.

O pesquisador respondeu que para o caso em que o referencial adotado é o chão, o apagador teria energia potencial maior que zero. Um aluno, não identificado, cria uma situação hipotética para testar os limites de nossa explicação, a saber, "Mas e se ele estiver no chão e o chão sumir e ele cair. Fizer um buraco?". Chamamos a atenção para o fato de 
que, possivelmente, o aluno tenha colocado em conflito duas afirmações sobre a energia potencial gravitacional. De um lado, afirmamos que a energia potencial gravitacional está associada à altura de um corpo e sua capacidade de adquirir movimento se abandonado e, do outro, que a energia potencial gravitacional pode ser igual a zero em diferentes alturas dependendo do referencial adotado.

O aparente conflito gerado por estas afirmações possui sua origem no fato de que, frequentemente, associamos o valor zero com a ausência de energia potencial gravitacional quando seria mais apropriado entender que o zero corresponde a um valor de referência convencionado e a partir da qual os diferentes níveis de energia potencial gravitacional podem ser comparados entre si. Podem haver, inclusive, corpos com energias potenciais negativas dependendo do referencial adotado para a análise.

O questionamento do aluno é interessante porque indica que este compreendeu a situação paradigmática apresentada pelo professor ao utilizar a cadeira sobre a mesa. Compreendendo a regra subjacente ao exemplo do professor o aluno conseguiu explorar uma situação possível onde a queda ocorreria a partir do nível adotado como referencial.

Em seguida, apresentaremos alguns trechos dos diálogos que ocorreram em outro encontro da SD onde a temática principal eram os processos de transformação da energia que ocorriam em uma usina termo-elétrica. Logo no início do encontro, o pesquisador colocou um pequeno fogareiro sobre uma mesa no centro da sala, depositou certa quantidade de álcool gel em seu interior e, com um fósforo, acendeu o fogareiro. Em seguida, apresentou uma latinha vazia para os estudantes explicando que havia esvaziado ela anteriormente através de um pequeno furo que fizera com uma seringa e que, com a mesma seringa, havia colocado água no interior da latinha até preencher metade de seu volume. Essa latinha, com água, foi colocada sobre a chama do fogareiro. Ocorreu, então, o seguinte diálogo:

Tabela 13 - Reconhecendo a energia em uma maquete de usina termelétrica.

\begin{tabular}{cl} 
Sujeito & Fala \\
\hline PQ & Vamos lá, eu queria que vocês tentassem - de forma organizada - isso \\
& quer dizer "um de cada vez" dizer em que parte desse processo todo há \\
& energia. \\
A & No fogo. \\
PQ & No fogo... \\
A & No calor \\
PQ & No calor. Do fogo? \\
Z & É. \\
E & Claro. \\
\hline
\end{tabular}

No momento em que esta pergunta foi dirigida aos alunos, a água ainda não havia começado a ferver e, portanto, ainda não havia vapor de água saindo da latinha. A resposta dos estudantes $\mathrm{A}, \mathrm{E}$ e $\mathrm{Z}$ destacou os aspectos mais visíveis do fenômeno, os efeitos 
sensíveis da energia, a saber, a luz e o aquecimento produzido pelo fogo. Novamente, a energia potencial química não foi mencionada espontaneamente. No entanto, através de um questionamento proposto pelo pesquisador outros tipos de energia foram citados:

Tabela 14 - A energia inicial para o funcionamento da usina.

\begin{tabular}{cl} 
Sujeito & Fala \\
\hline PQ & Mas beleza, tem energia no fogo. Onde mais? \\
D & Fósforo \\
PQ & No fósforo! Onde mais? \\
T & Na água fervendo? \\
PQ & Na água que vai ferver. Certo. \\
T & Na latinha que vai ferver \\
PQ & Na latinha quente. A latinha não ferve. É difícil ferver lata cara, até dá. \\
& Pra latinha derreter você tem que passar o ponto de fusão dela que é \\
& muito alto. [...] Mas beleza, galera. Existe uma ordem na passagem de \\
& energia de um ponto pro outro? Quais que são os primeiros itens com \\
B & Fonergia? \\
PQ & O fogo é o primeiro? \\
Z & O fósforo \\
VR & Fósforo! \\
PQ & É o fósforo... Que mais? \\
Z e D & O gel \\
PQ & Tem o álcool gel. Tem um anterior, quem lembra? \\
D & A ação pra acender o fósforo. \\
PQ & Sou eu! O primeiro ente com energia sou eu. Eu pego e coloco o álcool lá \\
& com a energia do meu corpo, esses músculos. Depois eu pego a caixinha \\
& de fósforo, abro e risco (Imita os movimentos realizados para acender um \\
PQ & fósforo). Tem que ter energia pra riscar na caixa de fósforo. \\
& ... Então, o primeiro ente com energia foi eu. Eu peguei o fósforo e risquei. \\
& Tudo bem, na hora que eu risco já tinha que ter energia no fósforo. Então, \\
& o segundo item é o fósforo mesmo. E o terceiro, é o álcool gel. Eu pego \\
& a chama do fósforo e aproximo do álcool gel e então ativo a queima do \\
& ǵlcool. Beleza? A queima do álcool é a liberação da energia que está \\
& guardada nele. Então, o álcool tem energia guardada e o fósforo tem \\
& ele pegar fogo. Eu aproximo o fogo do álcool gel para ativar a liberação \\
& da energia do álcool, que é um fogo maior. E depois? O fogo está ali, a \\
& lata está ali, a água está ali. Que mais acontece? \\
\hline &
\end{tabular}

Neste trecho, alguns alunos mencionam a energia do fósforo e do álcool gel como resposta para a pergunta "Onde mais há energia?". Em seguida, o pesquisador chama a atenção dos estudantes para o fato de que, no fenômeno observado, a energia tem origem em alguns elementos e, no decorrer do processo, é transformada e transferida para outros elementos. Diante do questionamento acerca das origens da energia do fenômeno observado, 
os estudantes mencionam o fogo, o fósforo, o álcool gel e - finalmente - o movimento do pesquisador para acender o fósforo.

Por fim, o pesquisador destaca a sequência dos processos - de diferentes naturezas - utilizados para iniciar a combustão do álcool gel que será o combustível do protótipo de usina termo-elétrica apresentado aos alunos. A transformação da energia química dos músculos do pesquisador em movimento e, através do atrito do fósforo com a caixinha, a transformação da energia química do fósforo em fogo para, por fim, desencadear o processo de transformação da energia química do álcool gel em energia térmica e luminosa do fogo. Para dar sequência ao diálogo, o pesquisador pergunta o que aconteceria a partir de então na usina: 
Tabela 15 - Da energia térmica à cinética na usina termelétrica

\begin{tabular}{|c|c|}
\hline ijeito & Fala \\
\hline $\mathrm{Z}$ & Aquele som ali? Conta? \\
\hline PQ & O som conta! Mas ele não é a próxima etapa... Tem algumas anteriores. \\
\hline $\mathrm{E}$ & O processo de ebulição, vaporização? \\
\hline PQ & Vaporização ainda é depois do que eu estou pensando. \\
\hline $\mathrm{A}$ & O calor do fogo aquece a latinha. \\
\hline PQ & $\begin{array}{l}\text { Isso, a próxima etapa é, o calor do fogo é transferido para a lata. E a lata } \\
\text { aquece por estar em contato com o fogo. Qual é a próxima, depois do } \\
\text { aquecimento da lata? }\end{array}$ \\
\hline $\mathrm{D}$ & Esquentar a água. \\
\hline PQ & $\begin{array}{l}\text { A lata que está em contato com a água aquece a água. Então, o fogo } \\
\text { aquece a lata, a lata aquece a água, por contato, e depois? }\end{array}$ \\
\hline $\mathrm{D}$ & Ela evapora! \\
\hline PQ & $\begin{array}{l}\text { A água vai aquecendo, chega na temperatura de ebulição e começa a virar } \\
\text { vapor. Dentro da lata isso, né!? E depois? }\end{array}$ \\
\hline & $\begin{array}{l}\text { De novo. Minha energia ativa o fósforo e o fósforo ativa o álcool. O fogo } \\
\text { entra em contato com a lata e aquece a lata. A lata entra em contato } \\
\text { com a água e aquece a água. A água chega na temperatura de ebulição e } \\
\text { vira vapor. Lá dentro. Depois que ela vai virando vapor o que acontece? }\end{array}$ \\
\hline $\mathrm{D}$ & Vai sair! \\
\hline PQ & $\begin{array}{l}\text { Antes de sair, esse vapor se agita tanto que aumenta a pressão interna da } \\
\text { lata. A lata, se não tivesse o furo. }\end{array}$ \\
\hline $\mathrm{Z}$ & Ia explodir \\
\hline PQ & $\begin{array}{l}\text { Explodiria. Como ela tem o furo, essa pressão, esse vapor de água, escapa } \\
\text { pelo furo. E aí vocês observam este efeito que é simultaneamente visual, } \\
\text { porque você enxerga o vapor, e sonoro, você consegue escutar um sonzinho } \\
\text { do vapor saindo. Beleza? }\end{array}$ \\
\hline PQ & Pessoal, esse vapor saindo tem energia? \\
\hline $\mathrm{AL}$ & Tem \\
\hline PQ & Que tipo de energia? \\
\hline $\mathrm{E}$ & Térmica \\
\hline Z & De indução, né? \\
\hline PQ & Tem energia térmica, porque está quente e o que mais? \\
\hline $\mathrm{E}$ & Pressão? \\
\hline PQ & $\begin{array}{l}\text { Pressão é o que causa essa energia. A pressão interna é que causa essa } \\
\text { energia da qual eu estou falando. Que é, movimento. Ela tem energia } \\
\text { cinética que é energia de movimento. Então, olha só o que eu vou fazer. } \\
\text { Tem uma hélice aqui, acoplada num motor. }\end{array}$ \\
\hline
\end{tabular}

O pesquisador descreve algumas etapas do processo de transformação da energia térmica da chama em energia de movimento do vapor de água. Na ordem proposta, temos o seguinte fluxo de energia: Energia química do álcool gel é transformada em energia térmica e luminosa da chama. Energia térmica da chama, em contato com a lata, é transferida em energia térmica da lata. Energia térmica da lata, em contato com a água, é transferida 
para a água. A energia térmica da água pode ser compreendida como o aumento da energia cinética de suas moléculas. Com o aumento da energia cinética das moléculas de água, parte da água sofre mudança de estado e evapora. O aumento das moléculas de água com alto nível de energia cinética combinado com o confinamento das mesmas moléculas transforma o movimento desordenado das moléculas em um movimento organizado de moléculas de água que escapam pelo pequeno orifício da lata. Além de possuir energia térmica e cinética, o jato de vapor d'água produz energia sonora ao escapar pelo orifício da lata.

Gostaríamos de destacar dois pontos. Primeiro, que o pesquisador chama a atenção dos estudantes para a energia cinética, de agitação, do vapor sem falar explicitamente no modelo cinético da temperatura ${ }^{15}$. Segundo, que o pesquisador faz um uso do conceito de calor como se este se tratasse de um tipo de energia quando diz "Isso, a próxima etapa é, o calor do fogo é transferido para a lata.". Se pretendemos concordar com Doménech et al. (2007) afirmando que o calor, assim como o trabalho, é um processo de transferência de energia, então, não faz sentido afirmar que o calor seja transferido já que o calor é o próprio processo de transferência.

Finalizando a exposição aos estudantes, o pesquisador aproxima uma hélice acoplada a um dínamo do jato de vapor. Com isso, a hélice gira o dínamo que, por indução eletromagnética, acende um pequeno LED. Assim, a complexa cadeia de processos de transformação e transferência de energia capaz de gerar energia elétrica a partir da energia térmica obtida pela queima de um combustível é finalizada. Em seguida, o pesquisador reflete sobre a eficiência deste processo, ou seja, sobre as possíveis perdas de energia em cada uma das etapas do processo, descritas anteriormente:

$\overline{15}$ Teoria na qual a temperatura de um corpo é compreendida como uma grandeza macroscópica que reflete o estado de agitação das moléculas constituintes do mesmo corpo. 
Tabela 16 - Fluxo de energia na usina - Parte I

\begin{tabular}{|c|c|}
\hline jeito & Fala \\
\hline PQ & $\begin{array}{l}\text { A pergunta é: O álcool gel que eu coloquei ali tem uma certa quantidade } \\
\text { de energia armazenada, certo? Quando eu boto fogo nele, ele começa } \\
\text { a liberar a energia. Essa energia, que é liberada pelo álcool gel vai ser } \\
\text { totalmente utilizada para movimentar a hélice do motor? }\end{array}$ \\
\hline $\mathrm{Z}$ & Sim \\
\hline PQ & $\begin{array}{l}\text { U acha que sim, o T acha que sim. O X acha que não. E ainda tem uns } \\
\text { que não souberam opinar. Por quê? U }\end{array}$ \\
\hline $\mathrm{U}$ & Ué! \\
\hline MT & (Dão risada) \\
\hline $\mathrm{U}$ & Porque está direcionado o vapor pra ela. \\
\hline PQ & $\begin{array}{l}\text { Porque o vapor está direcionado para a hélice. Então, você acha que } 100 \% \\
\text { da energia do álcool será utilizada para movimentar as hélices? }\end{array}$ \\
\hline $\mathrm{U}$ & (Faz cara de dúvida) \\
\hline $\mathrm{Z}$ & Eu acho que não. \\
\hline PQ & $\begin{array}{l}\text { Você vê que tem um salto, né? Eu perguntei da energia do álcool e você } \\
\text { falou do vapor. Que o vapor está direcionado para ele. Então, tem coisas } \\
\text { subentendidas na sua fala. O que que se subentendeu? Você subentendeu } \\
\text { que toda a energia do álcool é utilizada para aquecer a lata, que toda a } \\
\text { energia térmica da lata passa para a água e que todo o vapor de água } \\
\text { atinge a hélice do motor. } \\
\text { (U fica pensativo.) }\end{array}$ \\
\hline $\mathrm{PQ}$ & E quem não subentendeu isso. Quem discorda de que seja assim? \\
\hline $\mathrm{S}$ & $\begin{array}{l}\text { Eu acho que parte da energia aquece a lata e as outras coisas e outra } \\
\text { parte alimenta o próprio fogo. }\end{array}$ \\
\hline
\end{tabular}

O argumento dos alunos que acreditavam que toda a energia química do álcool gel seria utilizada para colocar o dínamo em movimento era o de que assim seria porque o jato de vapor estava direcionado para as pás do dínamo. Esse argumento subentende que todo o fluxo de energia desde o álcool gel até o vapor seja linear, sem ramificações ou perdas. Assim, acreditamos que a exclamação "Ué!" de U se deva ao fato de que, para ele, parecia óbvio que se caso se desejasse realizar outra coisa com a energia da usina seria necessário direcionar o jato de vapor para outros objetos ou outros aparatos pois, caso contrário, toda energia produziria a rotação do dínamo.

O pesquisador conduz a reflexão de forma que o estudante $U$ perceba que desde a queima do combustível até o giro do dínamo pelo vapor existem diversos processos intermediários onde poderiam haver perdas da energia ou diferentes destinos para a energia. Encorajado pelas reflexões, o estudante S, que ainda não havia se manifestado sobre o tema, levanta a hipótese de que, na primeira etapa, parte da energia aquece a lata enquanto a outra parte é consumida na manutenção da própria combustão. Uma hipótese interessante que, talvez, só tenha sido explicitada diante do espaço proporcionado pelo questionamento da visão hegemônica da turma segundo a qual toda a energia seria 
aproveitada no movimento do dínamo. Outra hipótese é levantada em seguida:

Tabela 17 - Fluxo de energia na usina - Parte II

\begin{tabular}{cl} 
Sujeito & Fala \\
\hline E & Eu acho que uma parte dessa energia também vai para o ambiente. \\
PQ & Parte da energia vai para o ambiente? \\
E & Sim \\
PQ & Através do quê? \\
E & (Aluno fica em dúvida) \\
PQ & Tem uma coisa aí que você está investigando... Você está certo, mas é \\
& que "o ambiente"é uma ideia abstrata. Preciso de uma coisa concreta que \\
& faça o calor escapar. \\
PQ & O ar. \\
& O ar. Uma parte do calor é perdida pelo ar. Então esse fogo. Esse fogo \\
& aqui aquece a lata mas ele também aquece o ar em volta. Então, parte \\
& da energia do fogo vai aquecer o ar e não a lata. E vai ter uma pequena \\
& porcentagem aí que não vai para a lata porque vai para o ar. Beleza? \\
& Tem outro motivo, muito simples, para defender esse conceito de que não \\
& é 100\% da energia do álcool que vai para lá e esse motivo é que vocês \\
& conseguem enxergar a chama. Se você enxerga o fogo, quer dizer que parte \\
& da energia do álcool virou luz e não temperatura. Então, uma parte da \\
& energia do álcool aquece a lata mas tem uma parte que vira luz. E essa \\
& parte que vira luz não aquece a lata.
\end{tabular}

O indivíduo E afirma que parte da energia do álcool gel vai para o ambiente no sentido de que a chama não aquece somente a latinha mas também o ar ao redor de si e, portanto, nem toda a energia do fogo se converte em aumento de temperatura da lata. $\mathrm{O}$ pesquisador endossa a afirmação de E e acrescenta mais um motivo para que se defenda que nem toda a energia do álcool gel é transformada em movimento do dínamo, a saber, que a chama, além de aquecer, emite luz e luz é energia. Sendo assim, o simples fato de que podemos ver uma chama significa que parte da energia do combustível que a mantém acesa é transformada em luz que viaja até nossos olhos e, por isso, não aquece a lata.

Gradualmente, o modelo de fluxo de energia dos alunos é revisado e se expande para incluir, por exemplo, a transferência de energia térmica para as moléculas de ar que estão ao redor e a transferência de energia química em luz. Em seguida, o pesquisador pede para a turma supor que a energia química total do álcool gel fosse 1000 unidades de energia para, na sequência, avaliar uma situação hipotética com valores numéricos: 
Tabela 18 - Fluxo de energia na usina - Parte III.

\begin{tabular}{|c|c|}
\hline ijeito & Fala \\
\hline $\mathrm{PQ}$ & $\begin{array}{l}\text { Sim, a energia do álcool, pela combustão, se divide em luminosa e térmica. } \\
\text { A maior parte é térmica, mas tem luminosa também. Beleza galera, então } \\
\text { vamos supor - apenas num experimento mental - que a energia do álcool } \\
\text { seja o número } 1000 \text { e aí você perdeu } 100 \text { na forma de luz, você perdeu } 50 \\
\text { na forma de aquecimento do ar aí foi } 850 \text { para a lata. Desses } 850 \text { que foi } \\
\text { para a lata, quanto que aquece a água? }\end{array}$ \\
\hline $\mathrm{Z}$ & Vai ser metade. \\
\hline $\mathrm{E}$ & Uns $750 ?$ \\
\hline PQ & Metade? Pra onde vai a outra metade? \\
\hline $\mathrm{Z}$ & $\begin{array}{l}\text { É porque a metade vai aquecer a lata e a outra metade vai aquecer a } \\
\text { água. }\end{array}$ \\
\hline PQ & Quem que acha diferente? \\
\hline $\mathrm{R}$ & $\begin{array}{l}\text { Eu acho que esses } 850 \text { vai aquecer a lata e, depois, todos os } 850 \text { vai - por } \\
\text { contato - para a água. } \\
\text { (...) }\end{array}$ \\
\hline $\mathrm{T}$ & E a temperatura da lata vai ser diferente da que aquece a água? \\
\hline PQ & $\begin{array}{l}\text { A lata pode ficar mais quente do que a água, mas isso é porque a água } \\
\text { evapora. }\end{array}$ \\
\hline PQ & $\begin{array}{l}\text { Vamos supor que o fogo tem a temperatura de } 5000{ }^{\circ} \mathrm{C} \text {. A lata vai chegar } \\
\text { até, sei lá, } 150 \text { ou } 200{ }^{\circ} \mathrm{C} \text {. A água chegaria até } 200^{\circ} \mathrm{C} \text {, igual a lata, o } \\
\text { problema é que ela evapora antes. Em vez de ela aumentar a temperatura, } \\
\text { ela evapora. E aí você não observa mais aumento de temperatura. }\end{array}$ \\
\hline
\end{tabular}

Nesse trecho, podemos observar duas tendências na análise do fluxo de energia da lata para a água nela contida. Uma primeira tendência é a de reconhecer que apenas parte da energia térmica da lata será transferida para a água ainda que as propostas desta tendência possam divergir quanto aos montantes de energia e as razões. Uma outra tendência é a de acreditar que toda a energia térmica da lata será transferida para a água em seu interior pelo fato de que água e lata estão em contato. Esta última tendência, explicitada apenas pelo estudante $\mathrm{R}$, parece resgatar o modelo de fluxo linear e sem perdas da energia. Por algum motivo, talvez pela simplicidade e força desta imagem de linearidade do fluxo, o estudante $\mathrm{R}$ não aplicou as considerações realizadas na etapa de transferência da energia do fogo para a lata nesta nova etapa do processo. É possível que não tenha ocorrido ao estudante E que a lata aquecida também é capaz, por exemplo, de aquecer as moléculas de ar que estão ao seu redor perdendo, assim, parte de sua energia térmica para o ambiente, exatamente como ocorreu com o fogo.

O estudante T questiona sobre as temperaturas finais da água e da lata perguntando se seriam diferentes entre si. Entendemos que, possivelmente, essa pergunta indique que o estudante tenha feito alguma relação entre energia e temperatura visto que, diante do debate sobre a quantidade de energia transferida da lata para a água, o mesmo tenha 
esboçado uma dúvida relativa à temperatura. Em resposta ao estudante T, o pesquisador diz que as temperaturas da lata e da água seriam as mesmas apenas no caso em que a água não evaporasse, dado que as moléculas de água que alcançam a temperatura de $100^{\circ} \mathrm{C}$ se desprendem das demais moléculas que, estando abaixo de 100 graus Celsius, constituem uma massa de água no estado líquido. É importante ressaltar que a temperatura do vapor, da água no estado gasoso, é superior a $100^{\circ} \mathrm{C}$ e que a afirmação é verdadeira quando consideramos que a medição da água seja realizada exclusivamente na massa de água que se encontra no estado líquido.

Provavelmente ainda refletindo sobre o balanço energético entre lata e água, um estudante (F) pergunta se mesmo a parte da lata que não está em contato com nenhuma molécula de água contribui com o aquecimento da água no interior da lata: 
Tabela 19 - Fluxo de energia na usina - Parte IV.

\begin{tabular}{|c|c|}
\hline jeito & ala \\
\hline $\mathrm{F}$ & $\begin{array}{l}\text { É... Mesmo a parte da lata que não está em contato com a água aquece a } \\
\text { água? }\end{array}$ \\
\hline $\mathrm{PQ}$ & $\begin{array}{l}\text { Pois é... Então, tem água até a metade aqui, tinha - acabou de acabar a } \\
\text { água. A água que está em contato com a lata começa a aquecer. Beleza? } \\
\text { A parte da lata, que não está encostada na lata, também aquece. Então, } \\
\text { a pergunta dele. Essa parte que não está em contato com a água, a parte } \\
\text { superior, não aquece a água mas aí a água evapora, vira vapor e o vapor } \\
\text { se debate em todas as partes da lata. Quando uma molécula de água, o } \\
\text { vapor, bate na lata quente... Ela bate e volta mais agitada ainda. Então, } \\
\text { a parte superior da lata aquece a água que está em forma de vapor. Tudo } \\
\text { bem? Mas a lata também perde temperatura para o ambiente. O ar } \\
\text { que está ao redor da lata começa a aquecer. Então, daqueles } 850 \text { uma } \\
\text { partezinha, vamos supor } 50, \text { vai perder pro ambiente também porque tem } \\
\text { ar encostado ali. (...) Aí eu coloco essa hélice aqui. Dos } 800 \text { que bate na } \\
\text { hélice, quanto que vira energia de giro? }\end{array}$ \\
\hline $\mathrm{D}$ & Metade. \\
\hline PQ & $\begin{array}{l}\text { Metade? Por que metade? Alguém acha que é tudo? Toda energia do } \\
\text { vapor vira energia de rotação? }\end{array}$ \\
\hline NI & (Levanta a mão) \\
\hline $\mathrm{PQ}$ & Você acha? Quem acha que não? \\
\hline NI & Eu. Porque o vapor está na latinha, ele sai e perde pressão. \\
\hline PQ & Sim. \\
\hline NI & Então não é toda a energia. \\
\hline PQ & $\begin{array}{l}\text { É. O vapor, quando ele sai, se vocês notaram porque agora não está mais } \\
\text { ocorrendo mas... Ele sai fininho, com alta pressão e aí ele se dissipa, ele } \\
\text { abre e ele fica cada vez mais largo e menos concentrado. Se eu coloco o } \\
\text { motor mais perto da lata, eu consigo pegar melhor a energia do vapor... } \\
\text { Então, se eu coloco perto eu capto melhor mas eu não capto } 100 \% \text { por } \\
\text { quê? Então, duas coisas: Vai ter uma pazinha da hélice na frente do vapor, } \\
\text { certo? O vapor vai subir e vai empurrar essa hélice. Aí a hélice vai se } \\
\text { movimentar e vai sair da frente dele, do vapor. Então, Nesse momento } \\
\text { em que a hélice se inclina e deixa o vapor passar direto, você perde uma } \\
\text { parte da energia que continua no vapor, sem empurrar a hélice. }\end{array}$ \\
\hline
\end{tabular}

Em resposta ao aluno, o pesquisador afirma que mesmo a parte da lata que não está em contato direto com a água em seu interior contribui com o aquecimento da água no estado gasoso, pois as moléculas de água que se desprendem da massa líquida de água entram em contato com as paredes superiores da latinha possibilitando, assim, ocasião de transferência de energia cinética entre as moléculas da lata (mais quentes) e as moléculas do vapor de água (menos quentes). Além disso, o pesquisador chama a atenção para o fato de que a lata também pode perder energia térmica para o ambiente através do contato com as moléculas de ar ao redor. 
Em seguida, refletindo sobre o aproveitamento da energia do jato de vapor de água na produção de movimento do dínamo, o pesquisador chama a atenção para o não aproveitamento de parte da energia do jato de vapor d'água devido às perdas de energia que ocorreram por conta do choque das moléculas do vapor com as moléculas de ar, da construção da hélice e do aquecimento das pás do dínamo.

Estas reflexões parecem sinalizar para a possibilidade de se ter aprofundado, ao menos de uma maneira qualitativa, nas questões relativas à entropia ou "degradação da energia" e na teoria cinética da temperatura a partir da dificuldade de se transformar integralmente a energia do movimento desordenado das partículas (energia térmica) em um movimento ordenado do dínamo (energia cinética de um corpo no nível macroscópico). Seguem mais detalhes sobre essas reflexões:

Tabela 20 - Fluxo de energia na usina - Parte V

\begin{tabular}{|c|c|}
\hline jeito & Tala \\
\hline PQ & $\begin{array}{l}\text { Então, quando a hélice sai da frente do vapor, o vapor segue e a energia } \\
\text { dele não é aproveitada. Então, vamos supor que você projete uma hélice } \\
\text { que assim que uma pazinha sai da frente do vapor uma outra entra. Você } \\
\text { observa então que, em tese, } 100 \% \text { da energia é aproveitada. }\end{array}$ \\
\hline PQ & $\begin{array}{l}\text { Mesmo que a hélice seja } 100 \% \text { eficiente a gente perde energia aqui. Por } \\
\text { quê? Olha só! Quando o vapor bate na pá, ele empurra a pá mas ele não } \\
\text { faz só isso. Ele esquenta a pá também. Se ele esquenta a pá, então parte } \\
\text { da energia da molécula de ar vira térmica. Então, você não capta } 100 \% \text { no } \\
\text { movimento. Então, vamos supor que desses } 800 \text { que está no movimento } \\
\text { da molécula de ar }\end{array}$ \\
\hline $\mathrm{E}$ & Uns 200 perde. \\
\hline $\mathrm{PQ}$ & Uns 200 você perde para a temperatura. \\
\hline $\mathrm{D}$ & Inaudível \\
\hline $\mathrm{PQ}$ & $\begin{array}{l}\text { O vapor, ele ia passar direto. O vapor passa direto. Ele não fica preso na } \\
\text { hélice. }\end{array}$ \\
\hline $\mathrm{D}$ & Inaudível \\
\hline $\mathrm{PQ}$ & $\begin{array}{l}\text { Mesmo se for } 100 \% .100 \% \text { seria uma hélice assim. O vapor vem com energia } \\
\text { de movimento. Quando a hélice acaba de virar para o lado esse vapor que } \\
\text { estava empurrando perde energia, para. Aí o de baixo vem empurrando e } \\
\text { para. Aí utilizaria todo o movimento do vapor em movimento rotacional. } \\
\text { Só que, como aquece, uma parte sempre vai perder para o aquecimento, } \\
\text { beleza? }\end{array}$ \\
\hline
\end{tabular}

Os trechos de diálogos apresentados nos permitiram obter alguns detalhes do processo de aprendizagem do conceito de energia e, além disso, perceber a força que podem apresentar algumas imagens relacionadas ao conceito de energia. Destacaremos algumas considerações realizadas a partir das análises destes diálogos:

1. Os alunos apresentam dificuldades em reconhecer a energia potencial dos sistemas 
apresentados: Esta conclusão é sustentada por duas evidências principais, a saber, a exclamação do indivíduo D que dizia "Como que tem energia se não tem movimento nenhum? Isso não faz sentido!" (Tabela 6) e a dificuldade dos alunos em mencionar a existência de energias potenciais sem que o pesquisador fizesse provocações (Tabela 14). Fica evidente, assim, a importância do papel do professor para o ensino de conceito de energia, o papel da persuasão. Gottschalk (2015) afirma que o trabalho do professor é fundamentalmente um trabalho de persuasão:

Uma vez disponibilizada a vontade do aluno, o papel do professor é o de apresentar novos modos de ver uma situação usual, introduzindo novas técnicas e procedimentos que permitam ao aluno atribuir novos sentidos àquela experiência, e assim, alcançar um saber que é produto de toda uma herança cultural, e por conseguinte, constituído por essências de natureza convencional (GOTTSCHALK, 2015, pg. 28).

O professor é quem se esforça por persuadir os estudantes a ver determinadas situações de diferentes modos. Para isso, os estudantes precisam estar dispostos a aceitarem um conjunto novo de convenções para que sejam capazes de ver determinados fenômenos de outros modos, isto é, para que sejam capazes de atribuir novos sentidos à experiência.

2. Inicialmente, os alunos precisam aceitar algumas convenções para serem capazes de participar dos jogos de linguagem próprios da disciplina de física: Os alunos precisam aceitar que a energia de um corpo que cai em queda livre é fruto da transformação da energia da interação entre tal corpo e o planeta Terra para, posteriormente, compreenderem e aplicarem a conservação da energia mecânica e o princípio de conservação da energia em diferentes contextos. Um dos papéis do professor de física é persuadir os estudantes acerca dos aspectos constituintes da gramática da disciplina de física (Tabela 7).

3. Na medida em que incorporam a gramática do conceito de energia, os estudantes podem testar seus limites ou questionar sua validade: Após a afirmação do professor de que um corpo em queda livre tem sua energia potencial gravitacional completamente transformada em energia cinética para, ao se chocar com o solo, ter sua energia cinética transformada em som, um aluno aponta uma exceção dizendo "E se fosse uma pena?" (Tabela 11). Apenas estudantes que compreenderam suficientemente as regras de aplicação do conceito de energia no contexto da queda livre dos corpos é que poderiam cogitar a queda da pena como uma exceção, como uma situação problemática. Relembrando as palavras de Passmore (2010) sobre a possibilidade do desenvolvimento do espírito crítico por parte dos alunos:

Eles [os estudantes] têm que aprender uma variedade de regras. Têm que se pôr em dia com os conhecimentos que já tenham adquirido. 
Só desta maneira chegarão a uma posição na qual poderão criticar de maneira fecunda, de forma a sugerir alternativas (PASSMORE, 2010, pg. 143).

A assimilação da gramática do conceito de energia, em algum grau, é condição necessária para que os estudantes tenham a possibilidade de desenvolverem seu espírito crítico no que diz respeito às aplicações do conceito para a descrição de fenômenos da ciência ou mesmo questões contemporâneas mais complexas que a queda livre dos corpos.

4. O professor e o pesquisador conhecem o papel do referencial para o cálculo da energia potencial gravitacional, assim como o fato de que a energia potencial zero à altura zero é uma convenção: De fato, espontaneamente e sem a discussão prévia deste aspecto do conceito, o professor realizou uma intervenção na aula para apontar este fator (Tabela 12). Nem o professor e nem o pesquisador pensaram em problematizar o aspecto convencional e relativo da energia cinética em um momento que, talvez, fosse propício para a realização desta observação. Felizmente, o professor - sempre presente e atento à intervenção do pesquisador - tomou a liberdade de incluir o aspecto relativo da energia potencial gravitacional nas discussões com os estudantes.

5. Nos diálogos sobre as transformações da energia em uma usina termoelétrica, o conceito de energia foi ensinado em estreita relação com processos empíricos que puderam ser observados em tempo real pelos estudantes suscitando, assim, questões que, possivelmente, poderiam não ter sido levantadas sem a presença do aparato experimental: Uma das questões levantadas foi se o barulho emitido pelo movimento do vapor saindo da latinha era uma evidência de energia (Tabela 15). Além disso, os elementos empíricos com os quais o conceito de energia foram relacionados neste diálogo remontam alguns aspectos do contexto originário do princípio de conservação da energia. Resgatando nossas considerações sobre a multiplicidade dos usos de um conceito, multiplicidade estabelecida na etapa preparatória para o uso da linguagem, e resgatando nossas considerações sobre o papel da linguagem, e dos procedimentos a ela relacionados, para o empreendimento científico, destacamos a importância do ensino do conceito de energia em relação aos aspectos empíricos próprios de sua origem e próprios de suas aplicações atuais. Dessa forma, a diversidade dos aspectos da experiência possibilitarão um ensino menos dogmático do conceito. Diferentes relações de sentido poderão ser consideradas para o conceito de energia a partir dos diferentes aspectos notados nos aparatos experimentais, como foi o caso do som emitido pela fuga do vapor de nosso protótipo de usina termoelétrica.

6. A análise da cadeia de transformação e transferência de energia do protótipo de usina termoelétrica permite que os alunos identifiquem os diferentes mecanismos que possibilitam a transformação e a transferência de energia de uma parte do sistema a 
outra. Além disso, permite que os estudantes vislumbrem diferentes possibilidades de caminhos para o fluxo de energia para fora do sistema apresentado, isto é, perdas de energia para o ambiente. Essa coleção de processos de transferências e transformação de energia pode servir de fundamento para posteriores considerações a respeito da "degradação da energia", da entropia.

Evidenciamos, a partir das análises sintetizadas nesta seção, a presença de algumas imagens relacionadas ao conceito de energia que apresentaram obstáculos para a compreensão de determinados aspectos do conceito, em especial a imagem explicitada pela afirmação Somente existe energia quando há corpos em movimento. Além disso, destacamos o papel da persuasão na ampliação do espectro dos sentidos do conceito de energia e o papel de aparatos experimentais na constituição de uma gramática menos dogmática do conceito. Indicamos a necessidade do domínio da gramática do conceito de energia para a possibilidade de pensamento crítico, para a possibilidade da dúvida, com relação às aplicações do conceito nas mais diversas situações.

\subsubsection{Pós-teste e aprofundamento de algumas análises}

Após a aplicação da SD, os alunos realizaram o pós-teste que consistia na análise e alteração do próprio pré-teste entregue no início da SD. O gráfico abaixo apresenta os dados do pré e do pós teste em contraste:

Gráfico 5 - Comparação entre Pré-teste e Pós-teste - Parte I

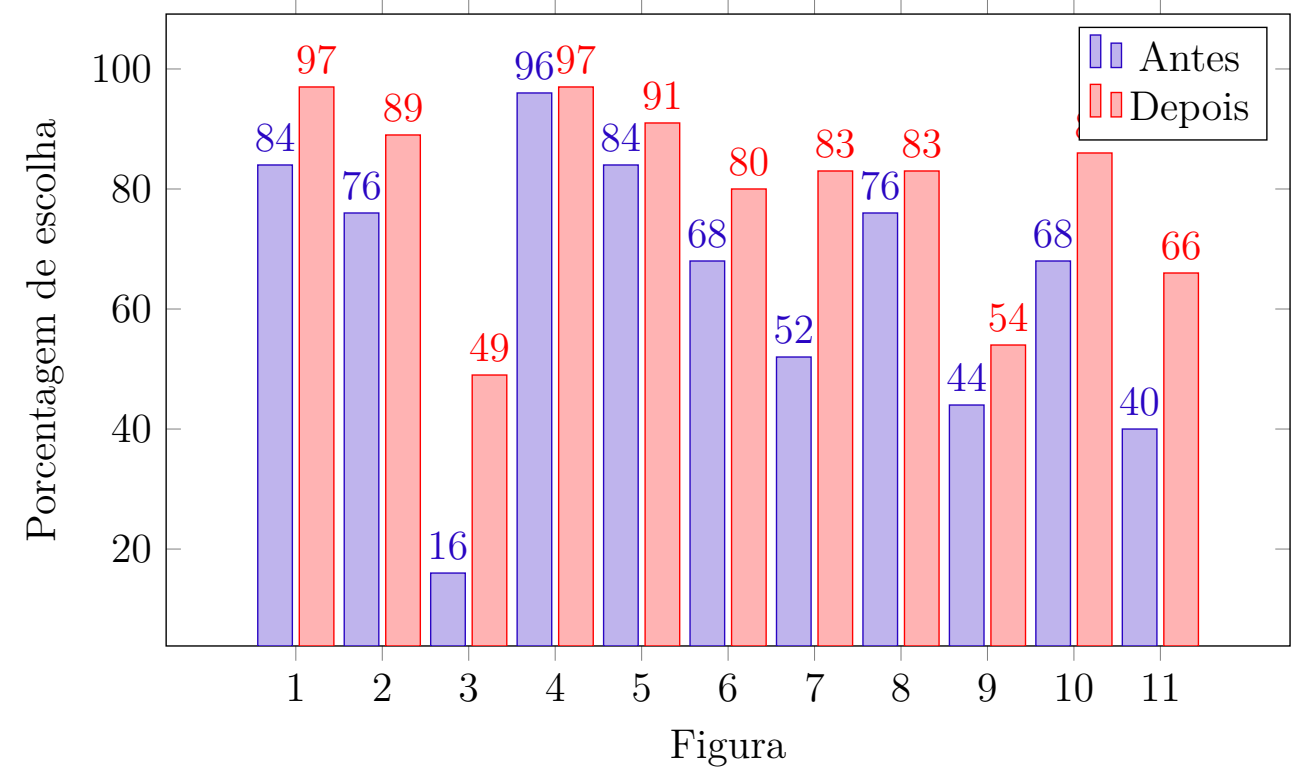




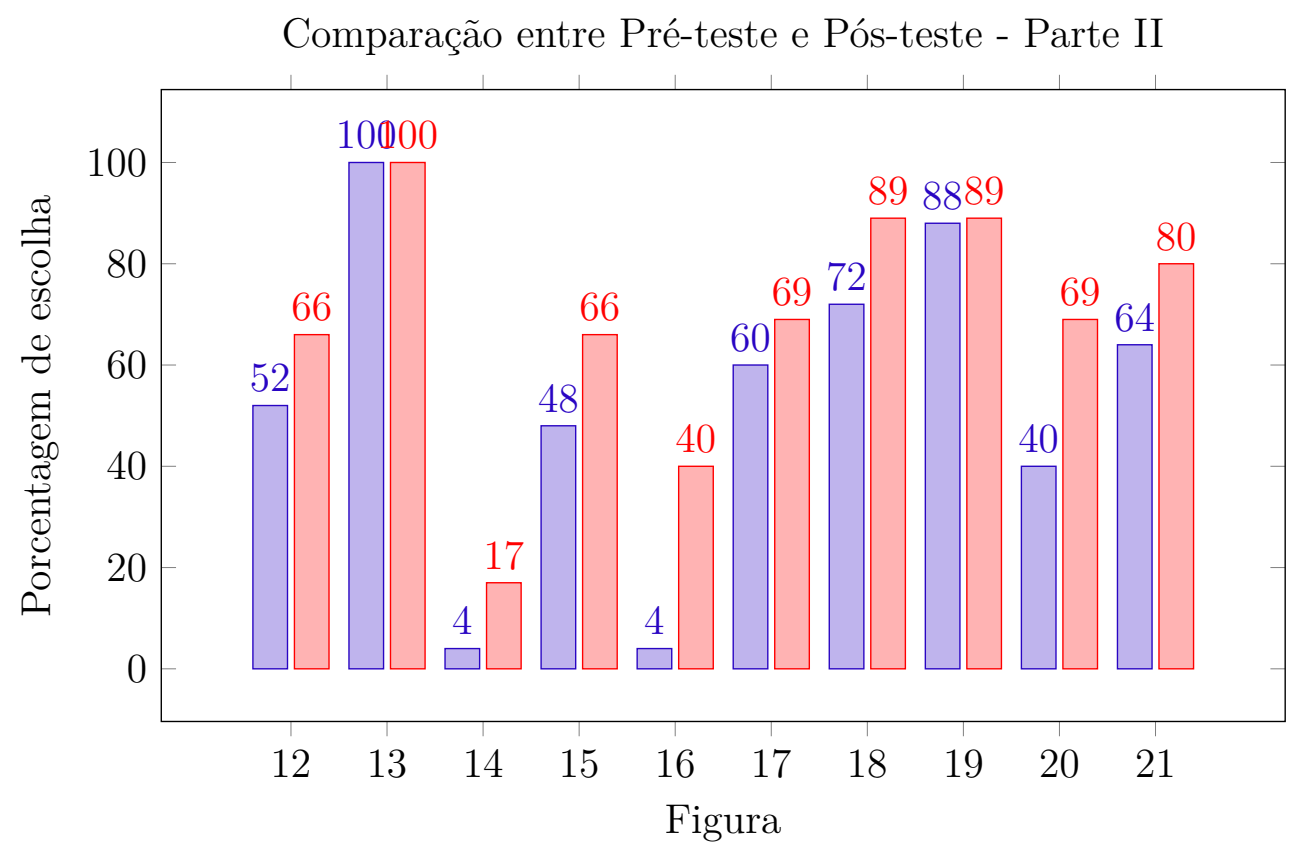

As situações com aumentos mais notáveis são as de número 3, 7, 11, 14, 16 e 20 que - com exceção das situações 7 e 11 - correspondem todas às situações de energias potenciais relacionadas com àquelas discutidas durante a SD. Nota-se, por exemplo, que as situações 9 e 17 - relacionadas à energia potencial elástica - apresentou um tímido aumento quando comparadas com as situações de energia potenciais gravitacionais e químicas. Isso, possivelmente, se deve ao fato que não abordamos a energia potencial elástica ao longo da SD.

Aprofundando nossas análises, selecionamos 5 casos de alunos para analisar com maior nível de detalhamento. Esses alunos foram obtidos da seguinte maneira: primeiro selecionamos os alunos que participaram em pelo menos 6 dos 8 encontros da SD aplicada e que haviam entregue pelo menos 6 das 8 atividades solicitadas durante a aplicação da SD. A aplicação deste filtro resultou num conjunto de apenas 7 estudantes. Como 2 destes 7 alunos não haviam realizado a última tarefa restaram apenas 5 estudantes.

A última tarefa consistia na alteração do pré-teste entregue no início da SD de forma a incluir novas situações onde se pudesse reconhecer a presença de energia e/ou alterar as justificativas anteriormente fornecidas para cada situação escolhida. Estes 5 alunos selecionados foram nomeados pelas letras A, B, C, D e E em todo este documento, inclusive nos diálogos apresentados anteriormente.

O gráfico abaixo representa uma síntese das respostas fornecidas ao pré-teste e ao pós-teste por cada um destes alunos: 
Gráfico 6 - Pré e Pós testes dos estudantes selecionados

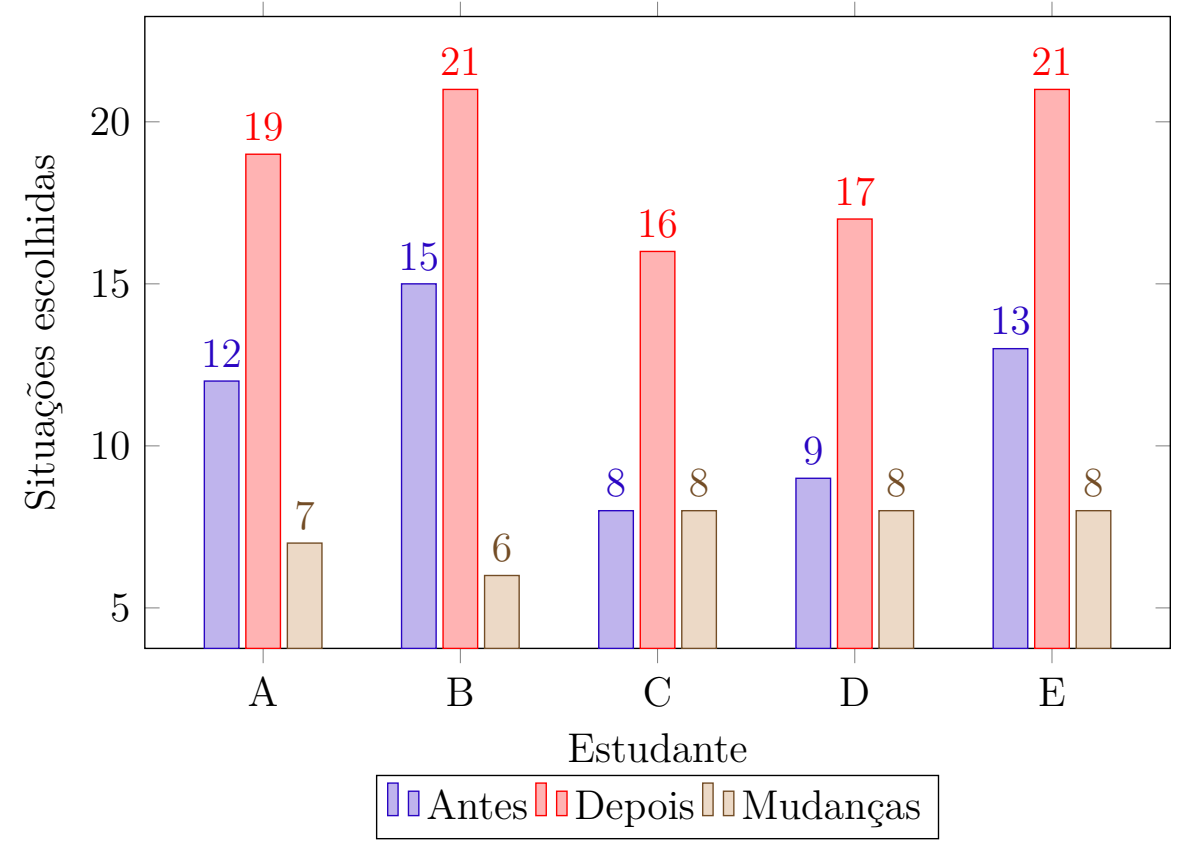

O conjunto de alunos selecionados apresentou uma média de 7 adições de situações no pós-teste, isto é, de situações que não haviam relacionado com energia inicialmente. Quatro situações do teste foram adicionadas por mais da metade dos estudantes selecionados, são elas:

Figura 16 - Situações mais adicionadas pelos 5 alunos selecionados

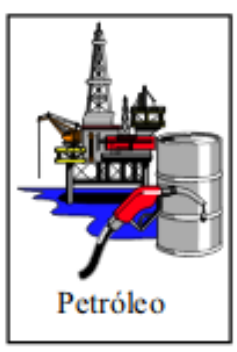

[ ] 3

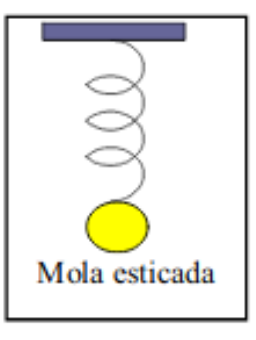

[ ] 9

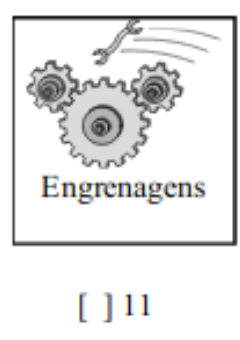

[ ] 11

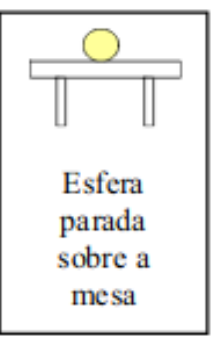

[ ] 16

A situação 3 foi adicionada por 4 estudantes, as situações 9 e 11 por 3 e a situação 16 por todos eles. É interessante notar que 3 destas situações dizem respeito à energias potenciais: potencial química (situação 3), potencial elástica (situação 9) e potencial gravitacional (situação 16).

As justificativas apresentadas para a inclusão destas situações foram baseadas no fato de o petróleo ser utilizado para a produção de combustível de automóveis e máquinas industriais, de a mola esticada adquirir movimento quando solta e de que a esfera está posicionada acima do nível do solo.

Acreditamos que a intervenção nas aulas cujos diálogos foram apresentados neste capítulo podem ter influenciado a inclusão dos itens acima citados. Os itens 3, 11 e 16 
parecem indicar uma associação direta entre petróleo e álcool gel, engrenagens e hélices do dínamo e esfera sobre a mesa com a caixinha de fósforo sobre a mesa, respectivamente. Já o item 9 parece ter sido incluído por uma razão diferente. Uma hipótese que consideramos é a de que o item 9 tenha sido incluído pela incorporação e aplicação da regra expressa pela proposição gramatical se pode adquirir movimento, então possui energia potencial.

Dado o engajamento dos estudantes nas reflexões relacionadas com a energia da caixa de fósforos deixada parada sobre a mesa e a sequência dada a discussão pelo pesquisador na qual afirma que a mesma adquire movimento sozinha se abandonada de certa altura (a partir da tabela 5), acreditamos que os estudantes concluíram que corpos que podem vir a adquirir movimento possuem energia. Assim, a partir desta possível conclusão, os estudantes podem ter concluído que esta mesma regra seria aplicável ao caso de uma massa esférica presa a uma mola esticada, ou seja, a massa poderia entrar em movimento devido à tensão da mola e, portanto, caberia falar em energia nessa situação.

Por fim, reforçamos que a finalidade da aplicação do pré e pós-teste não é a de validar a aplicação da sequência didática que desenvolvemos mas, antes, apresentar alguns indicadores da ampliação do espectro dos sentidos do conceito de energia devida aos processos de ensino e aprendizagem desenvolvidos ao longo da aplicação da SD. 


\section{Considerações finais e conclusão}

As reflexões propostas ao longo das páginas anteriores levantaram questões filosóficas sobre os usos do conceito de energia ensinados nas disciplinas de ciências, especificamente na disciplina de física do ensino médio, e tinham como objetivo apontar para a possibilidade da existência de imagens deste conceito que são privilegiadas na atividade de ensino. A partir da análise do material abordado, e da observação das aulas de física de uma turma do ensino médio da escola pública pudemos observar que:

I) O conceito de energia foi mencionado muito mais vezes - nas coleções de livros didáticos, no material de apoio do professor e nas aulas do professor - dentro do contexto da mecânica e da conservação da energia mecânica. Ainda neste contexto, o conceito de energia e transformação de energia foi fortemente relacionado ao conceito de trabalho. No material de apoio do professor e em suas aulas, por exemplo, o conceito de energia foi definido como a capacidade de um corpo realizar trabalho.

Esta tendência, em apresentar o conceito de energia com maior frequência no contexto da mecânica, pode favorecer o surgimento de imagens dogmáticas do conceito de energia dada a pobreza relativa de exemplos de uso do conceito em contextos diversos. Além disso, o ensino da mecânica se concentra, tradicionalmente, no primeiro ano do ensino médio e, portanto, a definição de energia que é apresentada neste contexto e momento poderá se consolidar como uma imagem reducionista e mecanicista do conceito caso não se reflita suficientemente a respeito de seus limites de validade e não se apresente novos sentidos para o conceito. Como já dissemos, a definição de energia como a capacidade dos corpos realizarem trabalho não se aplica para diversos campos da física, mas, antes, apenas para o contexto da mecânica e, portanto, a generalização indevida desta definição conduz a uma imagem dogmática do conceito de energia, a saber, uma imagem reducionista e mecanicista do conceito de energia.

II) O ensino dogmático de um conceito consiste em privilegiar um de seus modos de aplicação. Um dos indícios de uso dogmático do conceito de energia no campo da física é, em nossa opinião, a aproximação entre o princípio de conservação da energia e a conservação da energia mecânica, encontrada nas coleções de livros didáticos e na apostila utilizada pelo professor. Por um lado, esta escolha ensina tacitamente que o princípio de conservação da energia pode ser compreendido a partir da conservação da energia mecânica e, por outro, apresenta este princípio de forma descontextualizada ao ignorar seu contexto original de descoberta.

Não é raro que o princípio de conservação da energia seja apresentado em relação à conservação da energia mecânica em um momento em que, como dissemos, os estudantes 
não conhecem situações suficientemente diversas às quais se pode aplicar o conceito de energia favorecendo, assim, o surgimento de uma concepção reducionista do princípio de conservação da energia e, em consequência, do conceito de energia. Na prática, as situações de conservação da energia mecânica são apresentadas como paradigmas do princípio de conservação da energia, princípio de caráter muito mais geral que o primeiro.

Este ensino reducionista do princípio de conservação da energia não ocorre pela intenção dos autores de livros didáticos, mas porque no momento em que este princípio é introduzido os estudantes ainda não dominam suficientemente a gramática do conceito de energia. Por exemplo, não conhecem outros exemplos de transformação de energia, diferentes dos apresentados pelo professor no contexto da mecânica, que possam ser utilizados como situações paradigmáticas para a aplicação do princípio de conservação da energia.

III) Os estudantes frequentemente relacionaram o conceito de energia com corpos em movimento, corpos quentes ou dispositivos cujo funcionamento depende da energia elétrica como, por exemplo, celulares e televisores. Dificilmente os estudantes relacionaram o conceito de energia com sistemas onde, devido às interações entre os elementos que os constituem, podem haver transformações sem a interferência significativa de elementos externos. São exemplos destes sistemas a caixa de fósforos parada sobre a mesa e o álcool em gel utilizado como combustível no fogareiro. Estes fatos nos permitem concluir que situações onde a energia se manifesta em ato são mais facilmente reconhecidos que as situações onde há energias potenciais.

O fato descrito neste item parece ser fruto de uma imagem de energia como ente armazenado em um corpo ou como propriedade individual de um corpo visto que, a partir destas imagens, a energia seria algo que os objetos possuem ou não possuem em determinadas situações. Alguns exemplos das situações em que, a partir destas imagens, podemos falar de energia seriam, por exemplo, um corpo em movimento ou em combustão visto que podemos inferir a existência da energia a partir de fenômenos observáveis claramente associados a determinados corpos ou objetos. Por esse motivo, as formas potenciais de energia dificilmente são identificadas por estudantes que fazem uso exclusivo das imagens citadas acima.

As situações às quais podemos aplicar o conceito de energia potencial dependem da capacidade dos estudantes de analisar sistemas constituídos por corpos que interagem entre si e não apenas corpos isolados. Na verdade, do ponto de vista da física qualquer uso do conceito de energia com sentido diz respeito às propriedades de um sistema cujas partes interagem entre si e nunca a um corpo isolado. No entanto, a necessidade da compreensão deste caráter sistêmico da energia fica mais evidente quando pretendemos reconhecer formas potenciais de energia. Um exemplo de dificuldade causada pela aplicação dogmática destas imagens do conceito de energia foi a dificuldade que o indivíduo D apresentou 
para reconhecer formas de energia que não estivessem diretamente relacionadas com o movimento dos corpos.

IV) Os fenômenos apresentados durante a aplicação da Sequência Didática (SD) - a queda livre, o acendimento dos fósforos e o funcionamento da usina termoelétrica apresentaram uma dupla função. Em primeiro lugar, solicitamos que os alunos descrevessem e explicassem esses fenômenos fazendo uso do conceito de energia que já conheciam permitindo, assim, que pudéssemos perceber de que formas o conceito de energia já era utilizado pelos estudantes. Em segundo lugar, os fenômenos foram apresentados, a partir dos diálogos que conduzimos com os estudantes, como meio de apresentação do conceito de energia, como situações paradigmáticas de aplicação do conceito. A caixinha de fósforo suspensa a determinada altura do chão e a cabeça do fósforo, por exemplo, foram apresentadas como situações às quais podemos aplicar, respectivamente, o conceito de energia potencial gravitacional e energia potencial química.

O ensino de um conceito como, por exemplo, o conceito de "verde' consiste, em um primeiro momento, na apresentação de diversos objetos da cor verde acompanhados da palavra "verde" na forma escrita ou pronunciada. De forma semelhante, o ensino do conceito de energia consiste, inicialmente, na apresentação de diversas situações em que podemos empregar o termo energia. Tais situações precisam ser suficientemente diversas entre si para que os diversos sentidos do conceito de energia sejam contemplados. Evidentemente, este processo de apresentação dos sentidos do conceito de energia não precisa ocorrer de forma concentrada em um determinado período do ensino básico, mas, antes, pode ser distribuído ao longo de diferentes anos, disciplinas e temáticas segundo, por exemplo, um nível crescente de complexidade e abstração.

Diferentemente do ensino do conceito de verde, no ensino do conceito de energia não faz sentido apresentar objetos como paradigmas de aplicação do conceito mas, antes, situações às quais emprega-se o conceito recorrendo-se a diferentes técnicas de cálculo da quantidade de energia correspondente a cada situação. Através de estratégias de persuasão, foram introduzidos novos sentidos para o conceito de energia aos alunos que, na medida em que aceitaram novas convenções e as incorporaram à suas compreensões de energia, foram capazes de reconhecer novas situações onde a aplicação do conceito é possível.

V) A utilização de fenômenos reais e de aparatos experimentais nas discussões sobre o sentido do conceito de energia contribuíram para a complexificação da gramática do conceito na medida em que elementos empíricos, inicialmente não incluídos em nosso planejamento para as aulas, chamavam a atenção dos estudantes que, por sua vez, questionavam as relações entre o conceito de energia e tais elementos. São exemplos destes elementos empíricos, uma pequena explosão observada no fogareiro, o barulho do choque da caixinha de fósforos com o chão e o barulho produzido pelo vapor de água enquanto escapava pelo furo da latinha. A utilização de uma usina termoelétrica em pequena escala 
permitiu que aspectos intimamente relacionados com a origem histórica do conceito de energia fossem discutidos.

Uma das possíveis fontes do dogmatismo no ensino de ciências é a crença de que das definições gerais dos conceitos, leis e princípios se possa extrair todos os casos específicos a que tais conceitos, leis e princípios se aplica. Como se, de alguma forma misteriosa, as definições gerais já contivessem em si mesmas todos os casos particulares e concretos a partir dos quais foram abstraídas. Tal crença pode fundamentar a opinião de que os exemplos não sejam tão importantes para o ensino dos conceitos mas, antes, definições claras e precisas como se, por exemplo, uma definição clara e precisa do conceito de verde tornasse a apresentação de exemplos de corpos de cor verde desnecessária para o aprendizado deste conceito.

A utilização de fenômenos reais e de aparatos experimentais no ensino de conceitos inclui elementos complexos e multiformes, como costumam ser os elementos do mundo empírico, como amostras de objetos ou situações às quais os conceitos ensinados podem ser aplicados. Esta atividade de relacionar elementos do mundo empírico com os conceitos pode contribuir para um ensino menos dogmático visto que, inevitavelmente, traz à tona aspectos não considerados por determinadas imagens dos conceitos. Em nossa atividade de campo, este foi o motivo pelo qual os elementos empíricos citados no item $\mathrm{V}$ foram incorporados à gramática do conceito de energia uma vez que, inicialmente, não se pretendia abordá-los na SD.

VI) O pós-teste apontou para uma ampliação do sentido do conceito de energia no que diz respeito ao reconhecimento de situações às quais o conceito de energia pode ser aplicado com sentido. Essa ampliação do sentido do conceito de energia se mostrou, sobretudo, para situações mais diretamente associadas à energia potencial mecânica (gravitacional e elástica) e à energia potencial química. Possivelmente, este fato está associado às situações discutidas ao longo dos diálogos travados na SD onde fenômenos físicos foram apresentados como situações paradigmáticas para o uso do conceito de energia potencial.

O fato de nossas discussões a respeito do sentido do conceito de energia ter utilizado o funcionamento da usina termoelétrica e a queda livre da caixa de fósforos como fenômenos mediadores pode ter contribuído para este alargamento do conceito de energia dos estudantes que, após a SD, passaram a reconhecer novas situações à quais podemos aplicar o conceito de energia com sentido.

A partir das considerações realizadas acima, evidencia-se a importância do papel do professor que, por meio da persuasão, ensina seus alunos a verem de diferentes modos o conceito de energia possibilitando assim uma expansão do seu significado possibilitando-os observar, descrever e analisar de forma crítica diversos fenômenos relacionados com o conceito físico de energia. 
Evidenciamos, também, as dificuldades geradas por um ensino dogmático de ciências, especialmente do conceito de energia, para a formação de estudantes capazes de operar com o conceito de energia nos mais diversos contextos. As imagens do conceito de energia expressas pelas afirmações "apenas corpos com movimento possuem energia", "a energia é um ente armazenado no interior dos corpos", "energia nula significa a ausência de energia" e "a energia é a capacidade de um corpo realizar trabalho" constituem obstáculos à compreensão de determinadas características do conceito físico de energia sobre as quais diversos especialistas em ciências e ensino de ciências possuem consenso, a saber, que a energia é uma propriedade de sistemas, que não faz sentido falar em energia de corpos isolados, que a energia é uma quantidade que se conserva na medida em que os fenômenos naturais ocorrem, que a energia nula é apenas um caso numericamente especial de energia para um determinado referencial e que nem toda energia pode ser transformada em outras formas de energia por meio da realização de trabalho mecânico.

O domínio de diferente técnicas relacionadas ao conceito de energia possibilita que os estudantes observem determinados fenômenos, avaliem as possibilidades de transformação de determinados sistemas, critiquem projetos de máquinas e estações de energia, avaliem o consumo de recursos naturais e os impactos ambientais gerados por determinadas máquinas, posicionem com relação às decisões políticas de diferentes grupos e líderes. Mas não só no sentido de suas implicações sociais e políticas, externas à atividade científica. Pudemos observar um indício de desenvolvimento do espírito crítico - dentro do contexto da própria física - por um aluno participante da SD, o indivíduo Z, que questionou a aplicabilidade de uma explicação oferecida pelo pesquisador para o caso em que o objeto a ser abandonada em queda livre fosse uma pena. Com este questionamento, pudemos perceber que o estudante havia compreendido alguns elementos da gramática do conceito de energia no contexto da queda livre e passava a testar seus limites de validade.

É importante reiterar que não buscamos generalizar os resultados obtidos a partir da pesquisa empírica. Nosso objetivo foi, antes, o de refletir sobre alguns aspectos do ensino do conceito de energia que, acreditamos, podem dar origem a imagens dogmáticas do conceito, tendo como consequência pedagógica não apenas dificuldades para uma compreensão mais alargada do conceito, como também impedindo um pensamento crítico relativo a outras possibilidades de seu emprego.

Neste sentido, o papel das fontes de dados que selecionamos e apresentamos ao longo desta dissertação foi o de nos oferecer material concreto sobre o qual pudemos realizar nossas reflexões filosóficas, isto é, um conjunto de aplicações efetivas do conceito de energia encontradas em materiais de naturezas diversas: livros didáticos aprovados por programas nacionais, materiais de apoio elaborados por iniciativa individual de professores, aulas concretas de física e diálogos reais de sequências didáticas.

Ao se privilegiar determinados usos do conceito de energia propicia-se, por um lado, 
um aprendizado mínimo e aparentemente satisfatório; mas, por outro lado, dificulta-se a compreensão de diversos outros tipos de fenômenos e problemas, impedindo-se, assim, o tão propalado desenvolvimento do espírito crítico, como anunciado nos documentos curriculares já mencionados. Um ensino capaz de desenvolver o espírito crítico dos estudantes deve ser antes de tudo um ensino não dogmático. A ênfase nos processos de transformação da energia cinética em potencial gravitacional e a pobreza de exemplos relacionados aos demais processos de conversão e transferência de energia, por exemplo, podem não só dificultar, mas também inviabilizar, a compreensão do princípio de conservação da energia.

Apesar de nossas reflexões incidirem sobre materiais específicos como as coleções de livros didáticos, o material de apoio do professor, os exercícios propostos em suas aulas e os diálogos ocorridos durante a Sequência Didática (SD), nossas conclusões têm um caráter mais preventivo, ao indicarem uma tendência em privilegiar certos usos do conceito de energia na atividade de ensino de ciências, que não se restringem ao material aqui analisado. Além do que, de forma alguma, pretendemos fazer uma crítica direcionada a estes materiais uma vez que alguns destes elementos foram reproduzidos até mesmo pelo pesquisador enquanto conduzia a SD. Nossas reflexões tiveram por objetivo tratar de certas imagens dogmáticas do conceito de energia que se proliferam no ensino de ciências, para além do que pudemos analisar neste trabalho.

Ao termos identificado algumas imagens que surgem do uso do conceito de energia e apresentado modos de relativizá-las, esperamos ajudar os leitores a identificarem outras imagens, mostrando outras aplicações do conceito que escapem às previstas neste trabalho, superando-se, assim, dificuldades decorrentes de aplicações dogmáticas do conceito que podem levar a confusões nas práticas pedagógicas.

Embora a gramática de um conceito possa ser reelaborada na medida em que este conceito é aplicado nos mais diversos contextos, sugerimos - como desdobramento futuro desta pesquisa - avaliar se e de que maneira a gramática do conceito de energia, inicialmente muito relacionada à mecânica, tem sido reformulada e deslocada dos sentidos atrelados a este contexto. Isso poderia ser feito através de uma pesquisa de maior duração capaz de acompanhar o ensino deste conceito através de diversas disciplinas ao longo dos 3 anos do ensino médio ou, até, de alguns anos do ensino fundamental. Poder-se-ia também coletar informações de classes, professores e colégios de diferentes perfis executando, assim, um projeto de pesquisa empírico orientado pela perspectiva filosófica adotada neste trabalho. 


\section{Referências}

ALONSO, M.; FINN, E. J. Fundamental university physics. [S.1.]: Addison-Wesley Pub. Co, 1967. (Addison-Wesley series in physics).

ARONS, A. B. Development of energy concepts in introductory physics courses. v. 67, n. 12, p. 1063-1067, 1999.

ASSIS, A.; TEIXEIRA, O. P. B. Algumas considerações sobre o ensino e a aprendizagem do conceito de energia. Ciência Eamp; Educação (Bauru), v. 9, n. 1, p. 41-52, 2003.

AZANHA, J. M. P. Uma idéia de pesquisa educacional. 2. ed. ed. São Paulo: EDUSP, 2011. (Coleção Campi, n. 6).

BARBOSA, J. P. V.; BORGES, A. T. O entendimento dos estudantes sobre energia no início do ensino médio. v. 23, n. 2, p. 182-217, 2006.

BRASIL; MEC. Parâmetros Curriculares Nacionais para o Ensino Médio: Ciências da natureza, matemática e suas tecnologias. [S.l.]: Brasília: MEC/SEMTEC, 2000.

BRASIL; MEC. Base Nacional Comum Curricular. [S.l.]: Brasília: MEC, 2018.

BUNGE, M. La energía entre la física y la metafísica. Revista de Enseñanza de la Física, v. 12, n. 1, p. 53-56, 1999.

DOMéNECH, J. L. et al. Teaching of Energy Issues: A Debate Proposal for a Global Reorientation. Science \& Education, v. 16, n. 1, p. 43-64, jan. 2007.

DOMéNECH, J. L. et al. La enseñanza de la energía en la educación secundaria. Un análisis crítico. Revista de Enseñanza de la Física, v. 14, n. 1, p. 45-60, 2001.

DUIT, R. In Search of an Energy Concept. In: DRIVER, R.; MILLAR, R. (Ed.). Energy Matters. Leeds: University of Leeds, 1986. p. 67-101.

FEYERABEND, P. K. Contra o método. 2. ed. ed. São Paulo: Ed. Unesp, 2011.

FEYNMAN, R. P.; LEIGHTON, R. B.; SANDS, M. L. The Feynman lectures on physics. New millennium ed. New York: Basic Books, 2010.

GOTTSCHALK, C. M. C. O papel do mestre: Mênon revisitado sob um perspectiva wittgensteiniana. Memória clássica, 2015.

HERTZ, H. R. The principles of mechanics presented in a new form. Charleston: Bibliolife, 1956.

JANIK, A. S.; TOULMIN, S. A Viena de Wittgenstein. Rio de Janeiro: Campus, 1991.

KANTOR, C. A. et al. Coleção Quanta Física - Vol.1. 2.ed. ed. São Paulo: Pearson, 2013.

KUHN, T. S. A tensao essencial. Lisboa: Edicoes 70, 1989. (Biblioteca Contemporanea de Filosofia, 10). 
KUHN, T. S. A estrutura das revoluções científicas. 13. ed. ed. São Paulo: Perspectiva, 2017. (Debates, 115).

LAUDAN, L. Teorias Do Método Científico de Platão a Mach. Cadernos de História E Filosofia da Ciência, v. 10, n. 2, 2000.

MONK, R. Wittgenstein: o dever do genio. Sao Paulo: Companhia das Letras, 1995.

MORENO, A. R. Wittgenstein: através das imagens. 2. ed. ed. Campinas: Editora UNICAMP, 1995. (Repertórios).

MORENO, A. R. Introdução a uma pragmática filosófica: de uma concepção de filosofia como atividade terapêutica a uma filosofia da linguagem. Campinas, SP: UNICAMP, 2005.

MORENO, A. R. Por uma epistemologia do uso - Um aspecto do conceito wittgensteiniano de uso: Construção do signo e constituição do sentido. In: Wittgenstein e seus aspectos. Campinas: [s.n.], 2015, (Coleção CLE, v. 72). p. 89 - 115.

PASSMORE, J. On teaching to be critical. In: PETERS, R. S. (Ed.). The Concept of Education (International Library of the Philosophy of Education Volume 17). [S.1.]: Routledge, 2010. p. 134-147.

PEIRCE, C. S. Semiótica. 3.ed. ed. São Paulo: Perspectiva, 1999. (Coleção estudos).

PIETRoCola, M. et al. Física - Conceitos e Contextos: Pessoal, Social e Histórico Vol.2. 1.ed. ed. São Paulo: FTD, 2013.

POPPER, K. Os dois problemas fundamentais da teoria do conhecimento. São Paulo: Editora Unesp, 2013.

RYLE, G. Teaching and training. In: PETERS, R. S. (Ed.). The Concept of Education (International Library of the Philosophy of Education Volume 17). [S.l.]: Routledge, 2010. p. $73-82$.

SCHRöDINGER, E. O que é vida? o aspecto físico da célula viva seguido de Mente e matéria e Fragmentos autobiográficos. [S.1.]: Fundação Editora da UNESP Cambridge University Press, 1997.

TOULMIN, S. From Logical Analysis to Conceptual History. In: ACHINSTEIN, P.; BARKER, S. F. (Ed.). The Legacy of Logical Positivism. [S.l.]: Baltimore: Johns Hopkins University Press, 1969. p. 25-52.

WITTGENSTEIN, L. Investigações filosóficas. São Paulo: Nova Cultural, 2000. (Os Pensadores, v. 46).

WITTGENSTEIN, L. On certainty. Malden, Ma: Blackwell, 2010.

WITTGENSTEIN, L. Tractatus logico-philosophicus. 3.ed 2a reimp. ed. São Paulo: EDUSP, 2010.

WYKROTA, R. Apostila de Física Básica para E.J.A. Centro Estadual de Educação Profissional de Curitiba, 2012. Disponível em: <http://www.ceepcuritiba.com.br/ arquivos/Professores/Ronald\%20Wykrota/Fisica/APOSTILA\%20FISICA\%20parte\% 201\%20CEEP.pdf>. 